\title{
Effects of Aquifer Heterogeneity on Ground-Water Flow and Chloride Concentrations in the Upper Floridan Aquifer near and within an Active Pumping Well Field, West-Central Florida
}

By A.B. Tihansky

Prepared in cooperation with

Pinellas County and Tampa Bay Water

Scientific Investigations Report 2004-5268 


\title{
U.S. Department of the Interior Gale A. Norton, Secretary
}

\author{
U.S. Geological Survey \\ Charles G. Groat, Director
}

U.S. Geological Survey, Reston, Virginia: 2005

For sale by U.S. Geological Survey, Information Services

Box 25286, Denver Federal Center

Denver, CO 80225

For more information about the USGS and its products:
Telephone: 1-888-ASK-USGS
World Wide Web: http://www.usgs.gov/
Any use of trade, product, or firm names in this publication is for descriptive purposes only and does not imply
endorsement by the U.S. Government.

Suggested Citation: Tihansky, A.B., 2005, Effects of Aquifer Heterogeneity on Ground-Water Flow and Chloride Concentrations in the Upper Floridan Aquifer near and within an Active Pumping Well Field, West-Central Florida: U.S. Geological Survey Scientific Investigations Report 2005-5268, 75 p. 


\section{Contents}

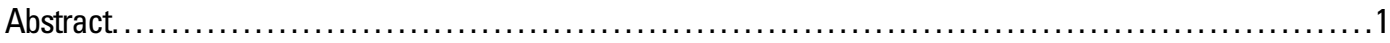

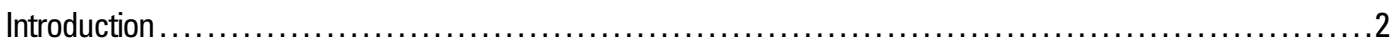

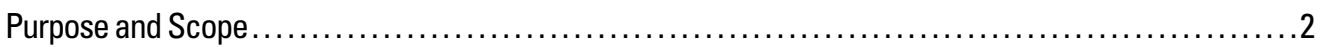

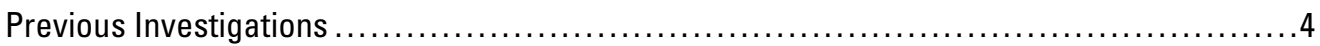

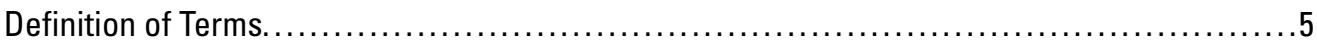

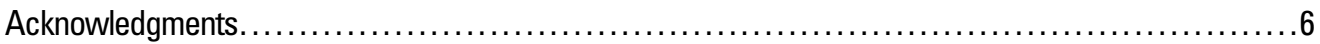

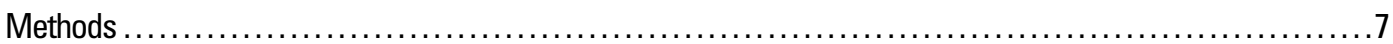

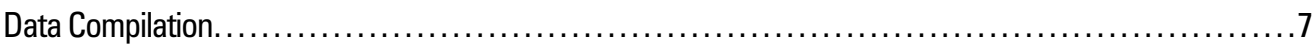

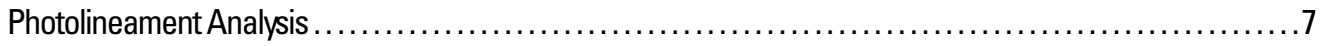

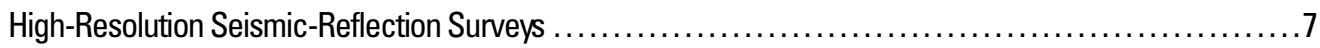

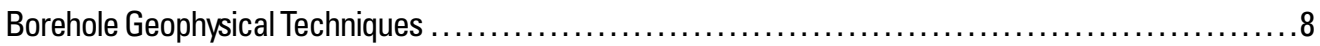

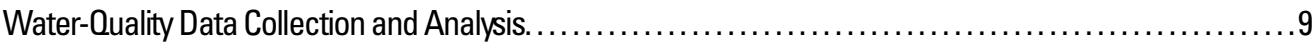

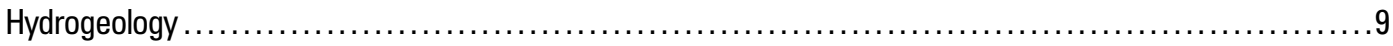

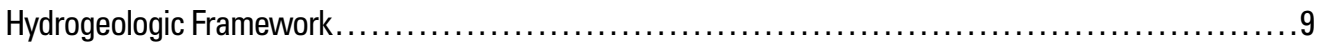

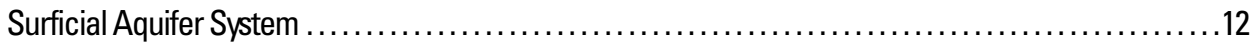

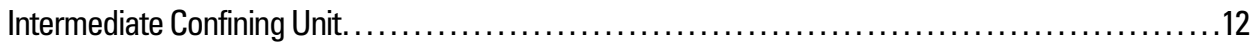

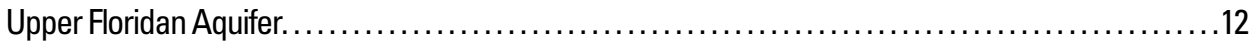

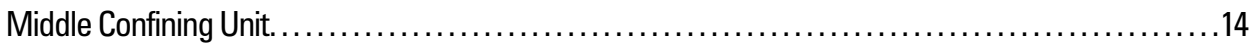

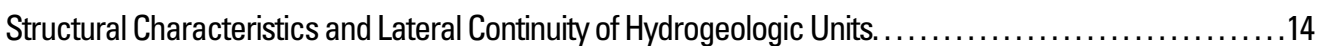

Delineation and Hydraulic Properties of Permeable Zones. .................................. 18

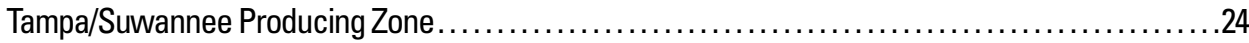

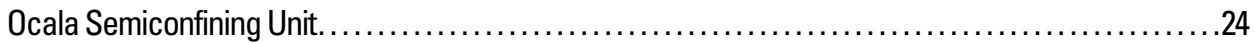

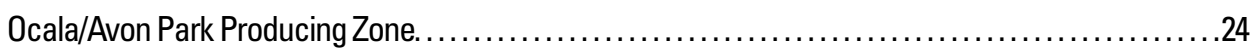

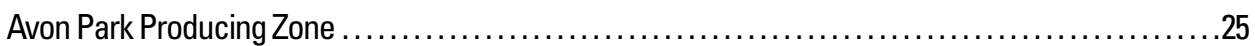

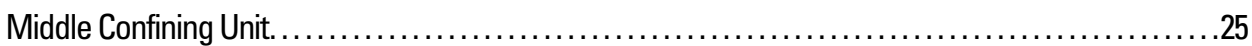

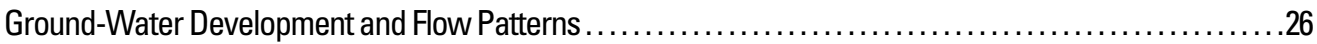

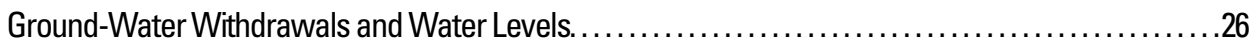

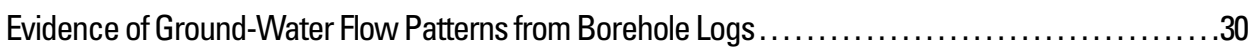

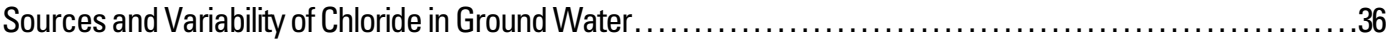

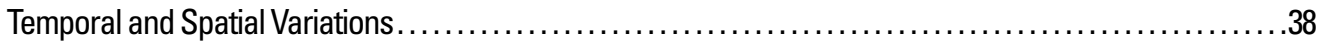

Chloride and Specific Conductance Variability in the Avon Park Producing Zone. .................... 47

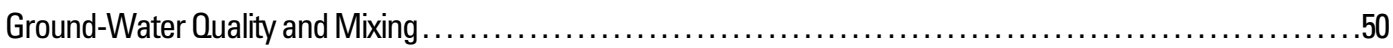

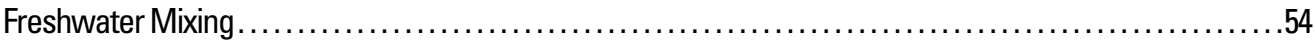

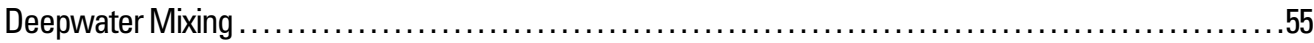

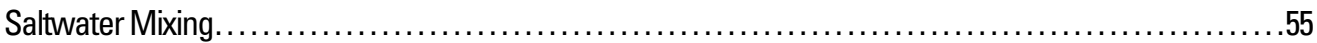

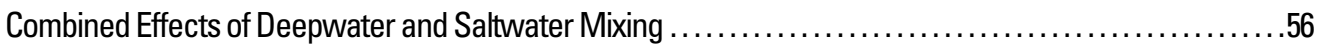

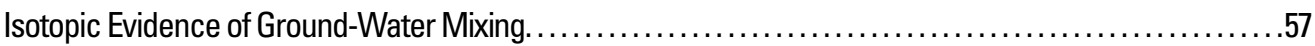

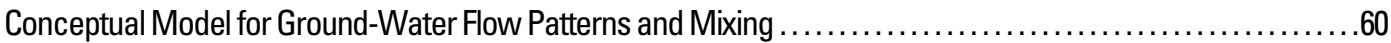

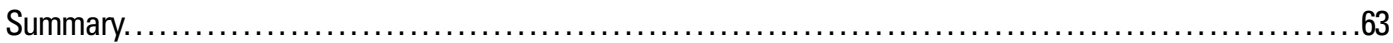

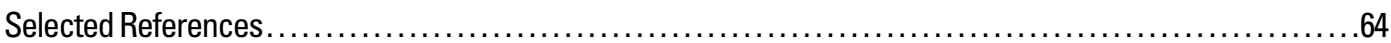

Appendix A. Well-Construction, Specific-Capacity, and Pump-Capacity Data for Production

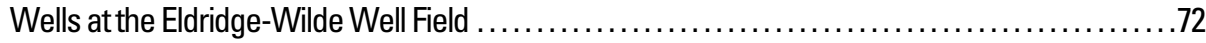

Appendix B. Well-Construction and Water-Quality Analytical Data for Wells Sampled During this Study 


\section{Figures}

1-2. Maps showing:

1. Location of study area and selected wells in surrounding regions, west-central

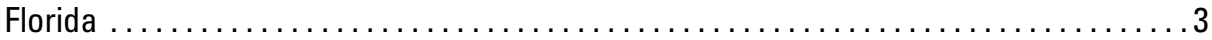

2. Location of the Eldridge-Wilde well field and adjacent areas showing locations of

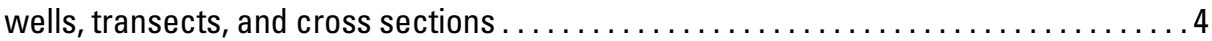

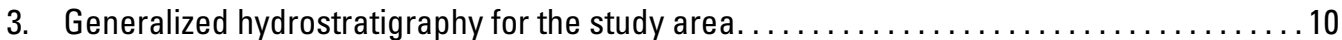

4. Stratigraphic sections $A-A^{\prime}, B-B^{\prime}$, and $C-C^{\prime}$ through the study area $\ldots \ldots \ldots \ldots \ldots \ldots \ldots$

5. Detailed hydrostratigraphic column of the study area with representative geophysical

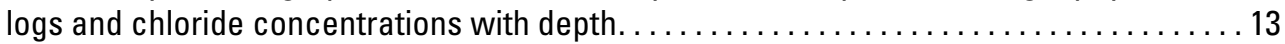

6. Map and graph showing location and orientation of fracture traces and photolineaments

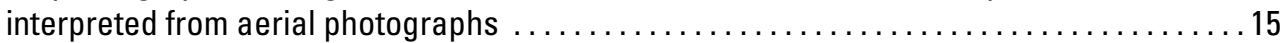

7. Seismic-reflection data for transects 1 and 4 , with geologic correlation and interpretations of subsurface features.

8. Acoustic televiewer log interpretations for selected boreholes located within the study area

9-10. Graphs showing:

9. Transmissivity of selected depth intervals and specific stratigraphic units of the Upper Floridan aquifer within or near the Eldridge-Wilde well field . .......... 21

10. Hydrogeologic units, producing zones, lithology, and caliper logs collected at selected wells located within or near the Eldridge-Wilde well field $\ldots \ldots \ldots \ldots \ldots \ldots \ldots 22$

11-12. Maps showing:

11. Specific capacity data for wells at the Eldridge-Wilde well field by final specific capacity, and final specific capacity normalized for length of open hole $\ldots \ldots \ldots \ldots 23$

12. Selected wells at the Eldridge-Wilde well field showing dates of well construction and wells that were deepened from original depth or acidized to increase production, and final well depths and pumping capacity (2002) . . . . . . . . . . . 27

13. Graph showing ground-water withdrawals from the Eldridge-Wilde well field, 1956-2000

14-15. Maps showing:

14. Regional potentiometric surface of the Upper Floridan aquifer for predevelopment conditions and May 2000 hydrologic conditions . . . . . . . . . . . . . . . . . . 28

15. Semi-annual potentiometric-surface maps and estimated decline of the Upper Floridan aquifer at the Eldridge-Wilde well field from predevelopment of

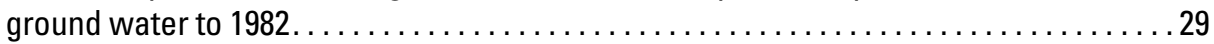

16. Graph showing water levels at Eldridge-Wilde Deep Well N3, 1977-2002 . . . . . . . . . . 30

17. Schematic showing conceptual illustration of types of aquifer heterogeneity and

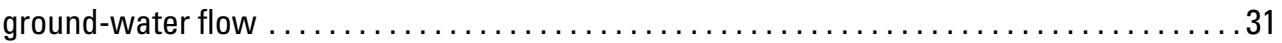

18-20. Graphs showing flow, caliper, and fluid conductance logs at Eldridge-Wilde:

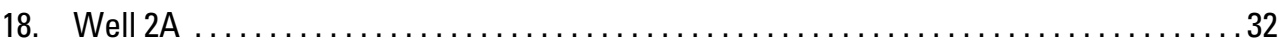

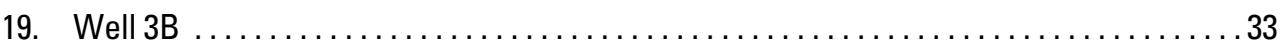

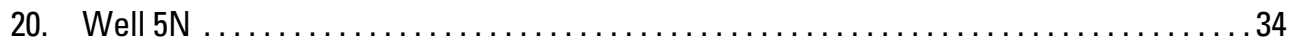

21. Graph showing flow, caliper, and fluid conductance logs and chloride concentrations obtained during drilling at well 201-M west of the Eldridge-Wilde well field ........... 35

22. Schematic sections illustrating possible physical processes for movement and introduction of chloride within the fresh ground-water system of the Upper Floridan aquifer.

23. Graph showing chloride concentrations and types of trends identified in water from the Upper Floridan aquifer in selected wells at the Eldridge-Wilde well field. . . 
24-26. Maps showing:

24. Distribution of annual average chloride concentrations in water from the Upper Floridan aquifer at the Eldridge-Wilde well field for $1995 \ldots \ldots \ldots \ldots \ldots \ldots \ldots 40$

25. Relation between the potentiometric surface of the Upper Floridan aquifer and chloride concentrations in ground water from the Upper Floridan aquifer at the

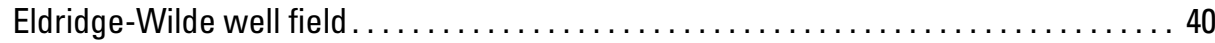

26. Temporal and spatial distribution of chloride concentrations in ground water from the Upper Floridan aquifer at the Eldridge-Wilde well field . . . . . . . . . . . 41

27-31. Graphs showing water levels and specific conductance of water from fixed depths at well:

27. SWI-1S, April 1995-September 1996.............................. 43

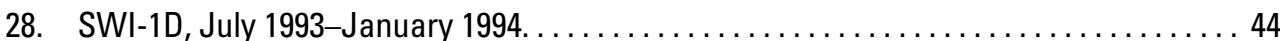

29. SWI-7D, June 1997-December 1998. . . . . . . . . . . . . . . . . . . . . . . . . . 45

30. SWI-10S and SWI-10D, April 1995-0ctober 1996....................... 46

31. Graph showing water levels and specific conductance of water at selected depths at wells 2A, 3B, and 201-M at the Eldridge-Wilde well field, December 1999-January $2001 \ldots 47$

32-34. Graphs showing:

32. Water levels, pumpage, and head difference at selected wells, and rainfall at the Eldridge-Wilde well field, December 1999 -January $2001 \ldots \ldots \ldots \ldots \ldots \ldots \ldots . \ldots 48$

33. Relation between ground-water pumpage, head differences, and continuous specific conductance at fixed depths in ground water at wells $2 \mathrm{~A}, 3 \mathrm{~B}$, and 201-M,

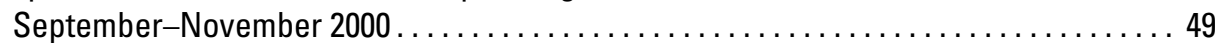

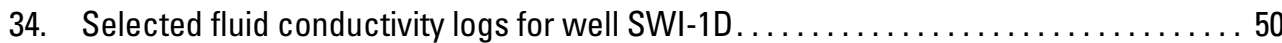

35. Schematic showing a generalized east-west geologic section, well construction, and water-quality characteristics of individual wells, including chloride concentrations, stiff diagrams, and percentages of end-member mixing within and west of the study area . ... 51

36. Piper diagram showing ground-water mixing trends between end members and ground-water samples within the study area............................. 53

37-40. Graphs showing:

37. Relation of sulfate-to-chloride equivalent ratio to sulfate concentration in water from the Upper Floridan aquifer in and near the Eldridge-Wilde well field and end-member mixing lines .................................................. 54

38. Relation between chloride concentration and specific conductance for ground-water samples obtained at specific depth intervals ................ 57

39. Relation between chloride concentration and delta oxygen-18 for selected Upper

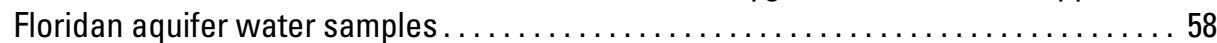

40. Relation between strontium isotope data and geologic units with chloride concentrations and sulfate enrichment above that from saltwater mixing 48 is 


\section{Conversion Factors and Datums}

\begin{tabular}{rcl}
\hline Multiply & By & To obtain \\
\hline inch (in.) & 25.4 & millimeter \\
foot (ft) & 0.3048 & meter \\
mile (mi) & 1.609 & kilometer \\
gallon per minute (gal/min) & 0.06309 & liter per second \\
million gallons per day (Mgal/d) & 0.04381 & cubic meter per second \\
& Hydraulic conductivity & \\
foot per day (ft/d) & 0.3048 & meter per day \\
& Specific capacity & \\
gallon per minute per foot & 0.2070 & liter per second per meter \\
{$[($ gal/min)/ft) $]$} & Transmissivity* & \\
& 0.09290 & meter squared per day \\
foot squared per day (ft $\left.{ }^{2} / \mathrm{d}\right)$ & &
\end{tabular}

${ }^{*}$ Transmissivity: The standard unit for transmissivity is cubic foot per day per square foot times foot of aquifer thickness $\left[\left(\mathrm{ft}^{3} / \mathrm{d}\right) / \mathrm{ft}^{2}\right] \mathrm{ft}$. In this report, the mathematically reduced form, foot squared per day $\left(\mathrm{ft}^{2} / \mathrm{d}\right)$, is used for convenience.

Temperature in degrees Celsius $\left({ }^{\circ} \mathrm{C}\right)$ may be converted to degrees Fahrenheit $\left({ }^{\circ} \mathrm{F}\right)$ as follows: ${ }^{\circ} \mathrm{F}=\left(1.8 \mathrm{x}^{\circ} \mathrm{C}\right)+32$ Vertical coordinate information is referenced to the "National Geodetic Vertical Datum of 1929 (NGVD of 1929)." Horizontal coordinate information is referenced to the "North American Datum of 1927 (NAD 27)."

\section{Acronyms and Additional Abbreviations}

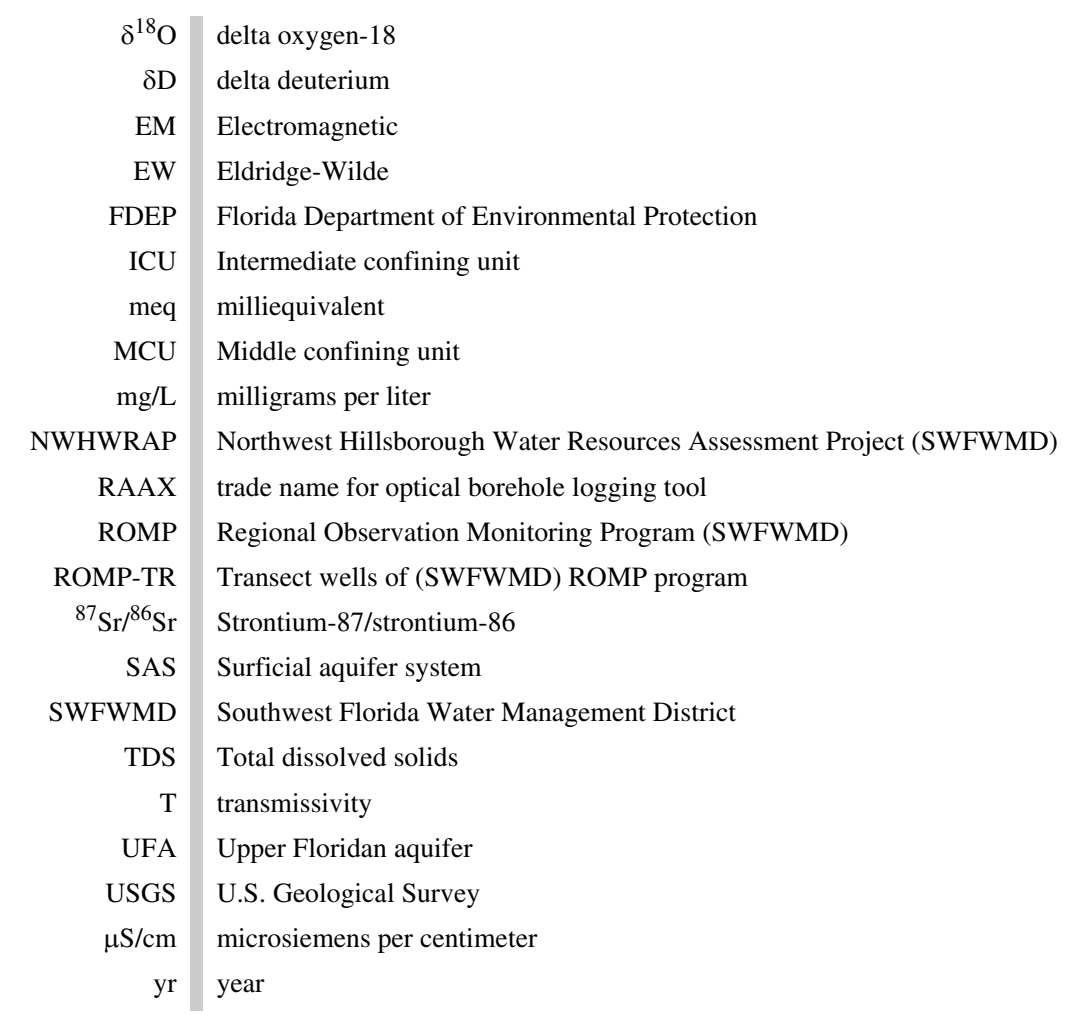




\title{
Effects of Aquifer Heterogeneity on Ground-Water Flow and Chloride Concentrations in the Upper Floridan Aquifer near and within an Active Pumping Well Field, West-Central Florida
}

\author{
By A.B. Tihansky
}

\section{Abstract}

Chloride concentrations have been increasing over time in water from wells within and near the Eldridge-Wilde well field, near the coast in west-central Florida. Variable increases in chloride concentrations from well to well over time are the combined result of aquifer heterogeneity and ground-water pumping within the Upper Floridan aquifer. Deep mineralized water and saline water associated with the saltwater interface appear to move preferentially along flow zones of high transmissivity in response to ground-water withdrawals. The calcium-bicarbonate-type freshwater of the Upper Floridan aquifer within the study area is variably enriched with ions by mixing with introduced deep and saline ground water. The amount and variability of increases in chloride and sulfate concentrations at each well are related to well location, depth interval, and permeable intervals intercepted by the borehole.

Zones of high transmissivity characterize the multilayered carbonate rocks of the Upper Floridan aquifer. Well-developed secondary porosity within the Tampa/Suwannee Limestones and the Avon Park Formation has created producing zones within the Upper Floridan aquifer. The highly transmissive sections of the Avon Park Formation generally are several orders of magnitude more permeable than the Tampa/Suwannee Limestones, but both are associated with increased ground-water flow. The Ocala Limestone is less permeable and is dominated by primary, intergranular porosity. Acoustic televiewer logging, caliper logs, and borehole flow logs (both electromagnetic and heat pulse) indicate that the Tampa/Suwannee Limestone units are dominated by porosity owing to dissolution between 200 and 300 feet below land surface, whereas the porosity of the Avon Park Formation is dominated by fractures that occur primarily from 600 to 750 feet below land surface and range in angle from horizontal to near vertical. Although the Ocala Limestone can act as a semiconfining unit between the Avon Park Formation and the Tampa/Suwannee Limestones, seismic-reflection data and photolinear analyses indicate that fractures and discontinuities in the Ocala Limestone are present within the southwestern part of the well field. It is possible that some fracture zones extend upward from the Avon Park Formation through the Ocala, Suwannee, and Tampa Limestones to land surface. These fractures may provide a more direct hydrologic connection between transmissive zones that are vertically separated by less permeable stratigraphic units.

Ground water moves along permeable zones within the Upper Floridan aquifer in response to changes in head gradients as a result of pumping. Borehole geophysical measurements, including flow logs, specific conductance logs, and continuous monitoring of specific conductance at selected fixed depths, indicate that borehole specific conductance varies substantially with time and in response to pumping stresses. Ground-water mixing between hydrogeologic units likely occurs along highly transmissive zones and within boreholes of active production wells. Ground-water movement and water-quality changes were greatest along the most transmissive zones.

Variable mixing of three water-type end members (freshwater, deepwater, and saltwater) occurs throughout the study area. Both deepwater and saltwater are likely sources for elevated chloride and sulfate concentrations in ground water. Mass-balance calculations of mixtures of the three end members indicate that deepwater is found throughout the aquifer units. Samples from wells within the southwestern part of the well field indicate that deepwater migrates into the shallow permeable units in the southwestern part of the well field. Deepwater contributes to elevated sulfate and chloride concentrations, which increase with depth and are elevated in wells less than 400 feet deep. 


\section{Effects of Aquifer Heterogeneity on Ground-Water Flow and Chloride Concentrations, West-Central Florida}

The greatest increases in chloride concentrations over time are found in water from wells closest to the saltwater interface. Ground water with a saltwater influence occurs primarily within the Avon Park producing zone nearest the saltwater interface, deeper in the aquifer system. Because chloride concentrations in saltwater are greater than those associated with deepwater, even small percentages of saltwater have a substantial effect on chloride concentrations. The highest percentages of saltwater are found in ground water from 600 to 750 feet deep within the transmissive zone of the Avon Park Formation. Specific conductance logs and long-term chloride concentration data indicate that saltwater may move preferentially inland along this transmissive zone. Chloride concentrations range from 5,000 to more than 15,000 milligrams per liter between 640-780 feet below land surface in wells less than 1 mile southwest of the well field. Elevated chloride concentrations in the well field are highest in wells where the potentiometric surface has been lowered.

Lowered ground-water levels associated with the Eldridge-Wilde well field affect the regional potentiometric surface of the Upper Floridan aquifer and may provide the potential to induce saltwater movement along transmissive zones of enhanced secondary porosity. From 1997 to 2000, water with elevated chloride concentrations migrated into the Eldridge-Wilde well field within the highly transmissive zone of the Avon Park Formation between 600-750 feet below land surface. In 2000, chloride concentrations reached 250 milligrams per liter in monitor wells tapping this production zone beneath the center of the well field. Isotopic analyses of deuterium, oxygen-18, and strontium-87/strontium- 86 indicate that saltwater mixing is a primary source of the observed chloride.

\section{Introduction}

Chloride concentrations affect the quality and quantity of potable ground water in Pinellas County and other parts of coastal Florida. The Pinellas County peninsula (fig. 1) is surrounded by saltwater, and fresh ground-water resources are limited. Historically, Pinellas County has had difficulty supplying potable water from local ground-water sources. The first well fields were located near downtown St. Petersburg, in southeastern Pinellas County, but over time the ground-water supply became brackish. As demands for freshwater increased, supply wells were drilled in the northeastern part of the County where coastal influences and ground-water chloride concentrations were lowest.

The Eldridge-Wilde (EW) well field is less than 10 miles from the coast in northeastern Pinellas County and northwestern Hillsborough County (figs. 1, 2). The well field occupies about 2,000 acres and is one of the largest well fields in westcentral Florida in terms of areal extent and volume of water withdrawn.
The EW well field was constructed in 1954, and well-field operations began in 1956. Pre-development ground-water levels and flow patterns were affected once the well field began operating (Black, Crow, and Eidsness, Inc., 1970). Within the first several years of operation, potentiometric-surface maps of the area indicated decreased heads in both the Upper Floridan and the surficial aquifers. Between 1981 and 1986, the demand for increased production led to the deepening of 23 wells into the highly productive Avon Park Formation.

In 1975, chloride concentrations in ground water from the southwestern part of the well field were less than $20 \mathrm{mg} / \mathrm{L}$. By 1985, chloride concentrations in wells 2A and 3B (fig. 2) had increased to $28 \mathrm{mg} / \mathrm{L}$, and by 1996 , concentrations had increased to more than $100 \mathrm{mg} / \mathrm{L}$. Chloride concentrations also increased to more than $20 \mathrm{mg} / \mathrm{L}$ in surrounding wells in the southwestern part of the well field. Analyses of chloride trends indicated that chloride concentrations could be anomalous, changing over time and spatially throughout the well field with no apparent pattern (Yobbi and others, 1996). These anomalous patterns suggested that specific features within the hydrogeologic framework control ground-water movement in the well field. Explanations for the different trends and rates of increases in chloride concentrations between wells included aquifer heterogeneity, preferential ground-water movement, structural features, and the influence of ground-water withdrawals.

In 1998, the U.S. Geological Survey (USGS), in cooperation with Pinellas County and Tampa Bay Water, initiated a study to investigate the hydrogeologic controls affecting sources of water to wells and to characterize the continuity of flow among wells. The study also provided an opportunity to investigate various techniques for delineating hydrogeologic controls on ground-water flow within the study area. This effort combined borehole and surface geophysical techniques with ground-water flow measurements and water-quality data to evaluate how structural features and aquifer heterogeneity affect the hydrogeologic and water-quality characteristics of aquifer units. The information presented in this report is provided to help water managers, planners, and others make scientifically based decisions regarding well-field management strategies in heterogeneous aquifers.

\section{Purpose and Scope}

This report describes the hydrogeologic framework and factors affecting the patterns of chloride concentrations observed in ground water within and adjacent to the EW well field. This report describes the methods of investigation, and combines historical data with data collected between 1998 and 2000 to describe the hydraulic characteristics and water quality within a heterogeneous multilayered aquifer system. Surfaceand borehole-geophysical data were analyzed and compared with hydrologic and water-quality data (table 1). The hydrogeologic framework describes the hydraulic properties of the aquifer units and their respective producing zones. The history and 


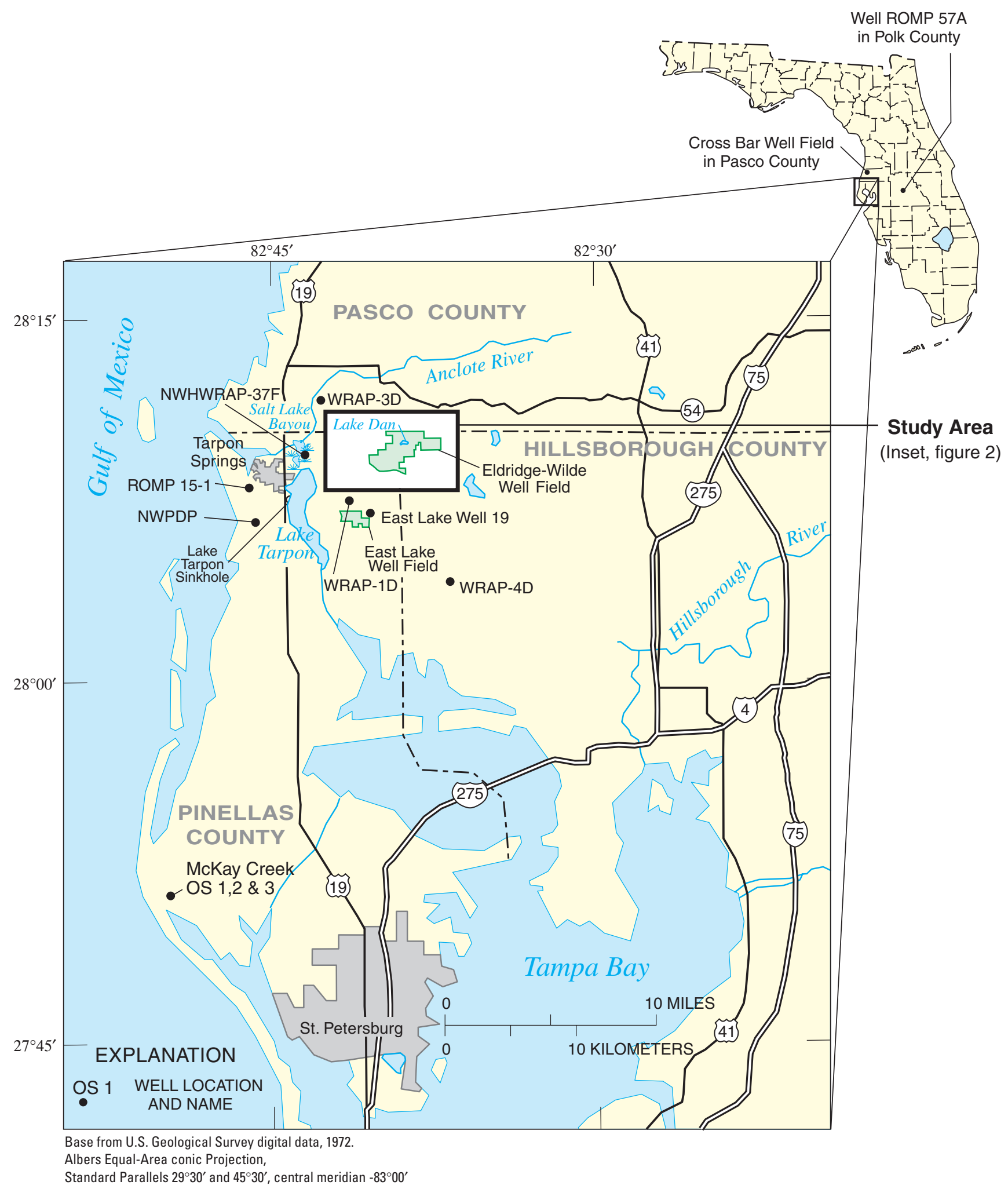

Figure 1. Location of study area and selected wells in surrounding regions, west-central Florida. 


\section{Effects of Aquifer Heterogeneity on Ground-Water Flow and Chloride Concentrations, West-Central Florida}

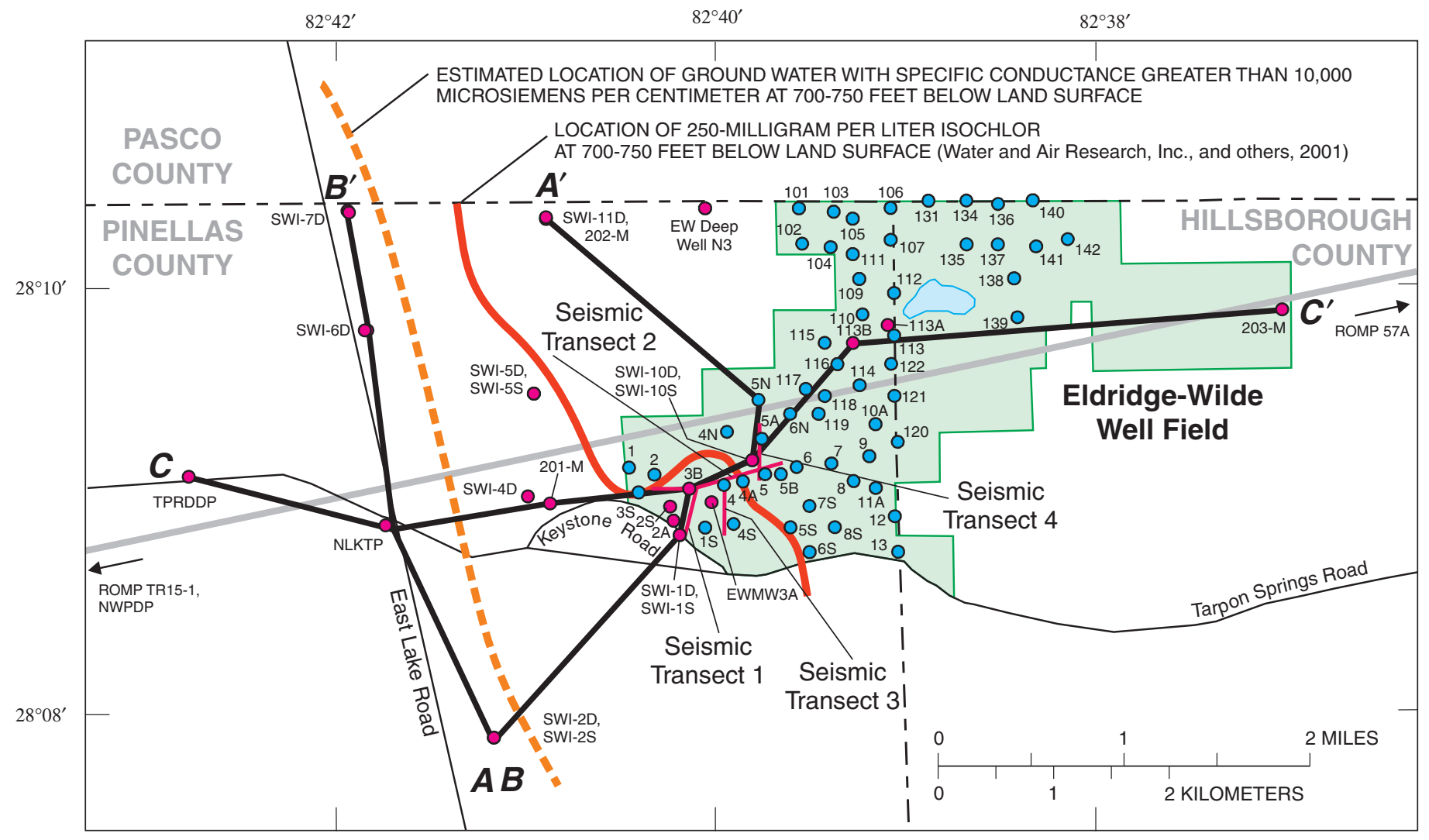

\begin{tabular}{|c|c|c|}
\hline \multicolumn{3}{|c|}{ EXPLANATION } \\
\hline$\underline{A-A^{\prime}}$ & $\begin{array}{l}\text { LOCATION OF CROSS SECTION-Trace of cross section shown in figure } 4 . \\
\text { LOCATION OF SEISMIC TRANSECT-Transects } 1 \text { and } 4 \text { shown in figure } 7 .\end{array}$ & $\begin{array}{l}\text { O MONITORING WELL LOCATION AND NAME } \\
\text { NLKTP } 13\end{array}$ \\
\hline 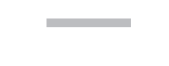 & $\begin{array}{l}\text { LOCATION OF CROSS SECTION-Trace of cross section shown in } \\
\text { figures } 22 \text { and } 35 .\end{array}$ & ${ }_{101}{ }^{\circ}$ PRODUCTION WELL LOCATION AND NAME \\
\hline
\end{tabular}

Figure 2. Location of the Eldridge-Wilde well field and adjacent areas showing locations of wells, transects, and cross-sections.

effects of ground-water development are related to their influence on ground-water movement and water quality. Groundwater quality characteristics and the distribution of chloride concentrations are described in terms of spatial, temporal, and vertical variations. A three-way mixing model is presented to describe observed concentrations of chloride from various permeable zones. The data were synthesized into a conceptual model, describing aquifer characteristics and ground-water flow to explain how hydrogeologic features affect the observed distribution of chloride within the ground-water system.

\section{Previous Investigations}

Many reports have been written on the hydrology at the EW well field, including reports associated with well-field construction and well construction and engineering (Black, Crow, and Eidsness, Inc., 1970; Gee and Jenson, Inc., 1981a,b, 1983; Nettles and Vandor, Inc., 1983, 1985, 1986, 1988a,b; Nettles and Associates, Inc., 1989, 1990, 1991a,b,c; 1992a,b,c).
Stewart (1968) and Joyner and Gerhart (1980) looked at the effects of pumping on the hydrology of the area and location of the saltwater/freshwater interface. A predevelopment potentiometric-surface map of the Upper Floridan aquifer was constructed by Johnston and others (1980). Potentiometric maps of the EW well field were prepared from 1978 to 1982 by the USGS (Hutchinson and Mills, 1977; Ryder and Mills, 1977a,b, 1978; Wolansky and others, 1978a,b; Wolansky, and others, 1979; Joyner and Gerhart, 1980; Yobbi, and others, 1980a,b,c; Yobbi and Woodham, 1981; Yobbi and Barr, 1982; Barr, 1982, 1983).

Hydraulic properties for aquifer units have been described in many previous investigations and from records compiled by the Southwest Florida Water Management District (SWFWMD), the USGS, and various consultants (Black, Crow, and Eidsness, Inc., 1970; Geraghty \& Miller, Inc., 1976a,b; Gee and Jenson, Inc., 1981a,b; Ryder, 1981; Gee and Jenson, Inc., 1983; Nettles and Vandor, Inc., 1985; Miller, 1986; Southwest Florida Water Management District, 1996a,b). Hydraulic characteristics for aquifer units within southwestern Florida were summarized by 
Table 1. Types of data collected or analyzed at selected wells located within the study area.

[Well locations shown in figures 1 and 2]

\begin{tabular}{|c|c|c|c|}
\hline \multirow[b]{2}{*}{ Well name } & \multicolumn{3}{|c|}{ Type of data } \\
\hline & $\begin{array}{c}\text { Continuous } \\
\text { monitoring } \\
\text { station }\end{array}$ & $\begin{array}{c}\text { Geophysical } \\
\log \end{array}$ & $\begin{array}{l}\text { Water } \\
\text { quality }\end{array}$ \\
\hline $2 \mathrm{~A}$ & $\mathrm{X}$ & $\mathrm{X}$ & $\mathrm{X}$ \\
\hline $3 \mathrm{~B}$ & $\mathrm{X}$ & $\mathrm{X}$ & $\mathrm{X}$ \\
\hline $5 \mathrm{~N}$ & & $\mathrm{X}$ & $\mathrm{X}$ \\
\hline $113-B$ & & $\mathrm{X}$ & $\mathrm{X}$ \\
\hline 201-M & $\mathrm{X}$ & $\mathrm{X}$ & $\mathrm{X}$ \\
\hline 202-M & & $\mathrm{X}$ & $\mathrm{X}$ \\
\hline 203-M & & $\mathrm{X}$ & $\mathrm{X}$ \\
\hline EW Deep Well N3 & $X$ & & \\
\hline EWMW3A & & $\mathrm{X}$ & $\mathrm{X}$ \\
\hline NLKTP & & & $\mathrm{X}$ \\
\hline SWI-1D & $\mathrm{X}$ & $\mathrm{X}$ & $\mathrm{X}$ \\
\hline SWI-1S & $\mathrm{X}$ & $\mathrm{X}$ & $X$ \\
\hline SWI-2D & & $\mathrm{X}$ & $\mathrm{X}$ \\
\hline SWI-2S & & $\mathrm{X}$ & $\mathrm{X}$ \\
\hline SWI-4D & & $\mathrm{X}$ & \\
\hline SWI-5D & & $\mathrm{X}$ & \\
\hline SWI-5S & & $\mathrm{X}$ & \\
\hline SWI-6D & & $\mathrm{X}$ & $\mathrm{X}$ \\
\hline SWI-7D & & $\mathrm{X}$ & $\mathrm{X}$ \\
\hline SWI-10D & $\mathrm{X}$ & $\mathrm{X}$ & $\mathrm{X}$ \\
\hline SWI-10S & $\mathrm{X}$ & $\mathrm{X}$ & $\mathrm{X}$ \\
\hline SWI-11D & & $\mathrm{X}$ & $\mathrm{X}$ \\
\hline TPRDDP & & & $\mathrm{X}$ \\
\hline
\end{tabular}

the Southwest Florida Water Management District (2000a), and the stratigraphic framework of the region and detailed local descriptions of the stratigraphy were described by Green and others (1995). Hammes (1992) and Loizeaux (1995) focused on the sequence stratigraphy and hydrologic properties of the Suwannee and Ocala Limestones, respectively.

Little published work relates large-scale structural features to local hydrogeologic trends. Within EW, photolinear features identified by Nettles and Vandor, Inc. (1988a) were presented to explain the observed anomalous trends in groundwater chloride concentrations. North of EW, Miller (1977) conducted a fracture trace analysis at the Cross Bar Ranch well field to select production well sites with optimum yields. Williams (1985), Nettles and Vandor, Inc. (1988b), and Diodato (1999) mapped photolinear features and correlated them to enhanced specific well capacity and ground-water quality anomalies. Spechler (1983) found that upward leakage of high chloride waters coincided with observed structural photolinear features in the Tarpon Springs area. Heath and Smith (1954) established that a sinkhole on the western shore of Lake Tarpon connects the lake to a spring vent in Tarpon
Springs along the Gulf of Mexico. Hunn (1974) further described the influence of karst features on water quality in the Lake Tarpon region. Spechler (1994), and Odum and others $(1997,1999)$ used seismic-reflection data techniques to identify large-scale breccia pipes that can create avenues of ground-water movement, linking the ocean to inland water resources.

Surface and borehole geophysical methods have been used to identify structural features associated with ground-water flow in west-central Florida. Safko and Hickey (1992), Duerr (1995), Metz and Brendle (1996), and Knochenmus and Bowman (1998) used borehole geophysical techniques to identify and measure ground-water flow in wells open to multiple aquifers to observe interaquifer flow via open boreholes.

Investigations that have focused on describing the location of the saltwater interface in the west-central Florida coastal region include Cherry (1966), Stewart (1968), Geraghty \& Miller (1976a, b), Causseaux and Fretwell (1982), Nettles and Vandor, Inc. (1988a,b), Sprinkle (1989), Maddox and others (1992), and Trommer (1993). A USGS data release (1985) and Yobbi and others (1996) identified water-quality trends in selected public-supply well fields. Other analyses regarding well-field operations and ground-water quality have been done by Geraghty \& Miller (1976a,b), HydroGeologic, Inc. (1992), and Southwest Florida Water Management District (1990, 1995, 1996a,b, 2000b). The location of the saltwater interface and $250-\mathrm{mg} / \mathrm{L}$ isochlor line presented in the 1996 annual report by Blasland, Bouck, and Lee (1997), and reports by Water and Air Research, Inc. (2000), and Water and Air Research, Inc., and others (2001) were particularly helpful to this study.

\section{Definition of Tems}

The following naming conventions and definition of terms are used in this report. Within the scientific community there are specific water-quality designations that delineate water type, ionic concentration, and potability. The conventions used in this report follow previously published work. The three primary chemical water types that mix within the study area are: sodium-chloride water, calcium-carbonate water, and calciumsulfate water. Sodium-chloride water reflects a seawater origin, and within this report is referred to as saltwater.

Calcium-carbonate water reflects the chemical signature of water that has interacted only with the carbonate aquifer minerals, with no influence of seawater. Calcium-carbonate water is referred to as freshwater. Ground water that moves along deep flow paths within the Upper Floridan aquifer interacts with evaporite units that contain gypsum, thus enriching the ground water with various ions including calcium and sulfate. Ground water enriched with calcium and sulfate is referred to as deepwater. 


\section{Effects of Aquifer Heterogeneity on Ground-Water Flow and Chloride Concentrations, West-Central Florida}

In the study area, deepwater along the saltwater interface moves to the surface as a result of density differences and regional flow (Cooper and others, 1964). This mechanism, which introduces deepwater into shallower depths, is referred to as upwelling. The process by which ground-water withdrawals create upward head gradients that induce deepwater to move upward is upconing. Both upwelling and upconing are associated with calcium sulfateenriched water occurring at shallower depths.

The saltwater interface is the contact zone between freshwater and saltwater. Under natural conditions, the boundary between freshwater and saltwater in coastal regions depends on the balance of forces in a dynamic system that can create a contact zone that varies in thickness. Normally, freshwater moves seaward at a rate that is related to the head above sea level in the freshwater aquifer. Saltwater intrusion results when freshwater heads decrease and saltwater migrates inland. Generally, the location of the saltwater interface approaches land surface near the coast and increases in depth landward. Freshwater and saltwater mix within a transition zone, but the locations of the interface and the transition zone are not stationary-they are in dynamic equilibrium, moving laterally and vertically depending on the head and movement of freshwater in the aquifer.

The position of the saltwater interface within the groundwater system has previously been identified and delineated by chloride concentrations, total dissolved solids concentrations, and specific-conductance ranges (Causseaux and Fretwell, 1982; Sprinkle, 1989; Maddox and others, 1992; Richter and Kreitler, 1993; Trommer, 1993). Salinity as described in this report is based on the following ranges of concentrations of total dissolved solids (TDS) (Hutchinson, 1992): freshwater, from $0-500 \mathrm{mg} / \mathrm{L}$; slightly saline water, from greater than $500-3,000$ $\mathrm{mg} / \mathrm{L}$; moderately saline water, from greater than $3,000-10,000$ $\mathrm{mg} / \mathrm{L}$; very saline water, from greater than $10,000-36,000 \mathrm{mg} / \mathrm{L}$; and brine, in excess of $36,000 \mathrm{mg} / \mathrm{L}$.

For this report, chloride concentrations and specific conductance are used to delineate saltwater and to indicate mixing. Saltwater (seawater) is defined as water having at least 19,000 $\mathrm{mg} / \mathrm{L}$ chloride, TDS concentration of at least $34,500 \mathrm{mg} / \mathrm{L}$, or specific conductance value of at least $50,000 \mu \mathrm{S} / \mathrm{cm}$. Freshwater is defined as water having a chloride concentration of $20 \mathrm{mg} / \mathrm{L}$ or less, and specific conductance value of less than $500 \mu \mathrm{S} / \mathrm{cm}$. The area in which the water quality falls between freshwater and saltwater is defined as the transition zone. Because chloride, TDS and specific conductance values vary widely in this zone, the chloride concentration commonly is measured to delineate where water becomes nonpotable. Causseaux and Fretwell (1982) mapped the $250-\mathrm{mg} / \mathrm{L}$ isochlor as the saltwater interface because this is the boundary where chloride concentrations exceed the Florida Department of Environmental Protection (FDEP) maximum drinking water contaminant level. Ground water containing approximately 1 percent seawater can increase chloride concentrations to the FDEP's maximum potable limits. Within the study area, the $250-\mathrm{mg} / \mathrm{L}$ isochlor generally corresponds to a specific conductance value of $1,000 \mu \mathrm{S} / \mathrm{cm}$ (which is TDS concentration less than $1,000 \mathrm{mg} / \mathrm{L}$ ). Moderately saline water, with specific conductance values greater than $10,000 \mu \mathrm{S} / \mathrm{cm}$, and chloride concentrations greater than $1,000 \mathrm{mg} / \mathrm{L}$, indicates a predominant influence of seawater.

In this report, both the $10,000-\mu \mathrm{S} / \mathrm{cm}$ specific conductance isoline and the $250-\mathrm{mg} / \mathrm{L}$ isochlor have been mapped to delineate the saltwater/freshwater interface, although they each represent varying levels of saline water present in the ground water within the study area. Water exceeding $250 \mathrm{mg} / \mathrm{L}$ of chloride is considered nonpotable and, therefore, represents the upper boundary of the saltwater interface. Where specific conductance of ground water exceeds $10,000 \mu \mathrm{S} / \mathrm{cm}$ in the study area, ground water becomes moderately saline and indicates that saltwater is likely influencing ground-water chemistry.

\section{Acknowledgments}

The completion of several critical tasks for this study depended on a number of individuals within and outside of the USGS. Locating and obtaining historical data depended on the assistance of several individuals. Within the Pinellas County Utilities Department: Dave Slonena provided many valuable reports on the EW well construction and modification history; Bruce Weber was helpful by providing historical water-quality data, occasional field assistance, and contacts for operational questions; Oz Wiesner provided the historical geophysical logs and calibration data; Jim Sanders and Royce Rarick at the Keller Water Plant provided additional well-field operational data and field support. Terry Thomas of Tampa Bay Water provided historical data and information regarding changes in monitoring efforts and additional work being conducted at the well field during this study. Bob Evans of SWFWMD provided one photolinear interpretation, as well as providing assistance and materials to Dave Diodato (USGS), who performed another photolinear interpretation. Borehole geophysical logging efforts would not have been possible without the help of John Williams (USGSOffice of Ground Water) and Alton Anderson who provided field assistance. Additional help with geophysical logging and interpretation was provided by the geophysical logging group within the USGS National Research Program: Fred Paillet, Richard Hodges, and Barbara Corland. High-resolution land-seismic reflection data collection, processing, and interpretation were completed with help from the USGS Hazards Group in Denver, Colorado, and many thanks are due to Jack Odum and Bill Stephenson for their assistance. Strontium isotope data were analyzed by Jon Martin at the University of Florida, and sample splits for quality assurance were run by Tom Bullen of the USGS. Bruce Weber with the Pinellas County Utilities Department, Jim Inman of the University of South Florida, Peter Swarzenski of the USGS, and personnel from the SWFWMD's Regional Observation Monitoring Program (ROMP) provided sampling assistance. Bob Bretnall with HSW Engineering, Inc., provided feedback during data analysis. Within the USGS, Laura Sacks, Dan Duerr, Ron Miller, Arturo Torres, Mario Fernandez, and Darren Meadows assisted with data management, analysis, and synthesis. Jane Eggleston provided editorial assistance in developing the draft report. 


\section{Methods}

Geologic, hydraulic, photolineament, geophysical, and water-quality data were used to assess the influence of geologic features on ground-water flow and distribution of chloride in the study area. Most geophysical methods are subject to multiple interpretations that benefit from, and commonly require, corroborative data from other sources. In this study, interpretations of surface and borehole geophysical data were related to water-quality data and historical information compiled during the study. A conceptual hydrogeologic model for the generalized movement of ground water was then developed for the area. The types and locations for various data-collection efforts are shown in table 1.

\section{Data Compilation}

Lithology and stratigraphy were reviewed from descriptions provided in previous reports of cuttings and cores collected during the drilling of wells in the study area (Black, Crow and Eidsness, Inc., 1970; Nettles and Associates, Inc., 1989-1992). Lithologic logs and drilling records from more than 30 production and monitor wells were used to correlate the stratigraphy within the study area and to construct geologic sections.

Hydraulic properties for specific geologic units were obtained from aquifer test data as well as borehole and core measurements. Porosity, transmissivity, hydraulic conductivity, and specific capacity values representing both large sections of the Upper Floridan aquifer and individual stratigraphic units were compiled.

Ground-water pumping data from 1956 to 2001 were compiled as were published water-level maps for the well-field area from predevelopment to 2000 .

Historical water-quality data from 1970 to 2000 , collected by the USGS and Pinellas County, were used to look at increasing trends in chloride concentrations, to identify sites to be sampled for additional water-quality analysis, and to better understand where and to what extent changes in the chemical composition of ground water have occurred. Historical data obtained from Pinellas County were thoroughly reviewed, and only samples for which the difference between the laboratory and field specific conductance was less than 10 percent were used for additional analysis.

\section{Photolineament Analysis}

Photolineaments are surface expressions of lineaments and fractures caused by tectonics and earth tides. Structural failure due to dissolution and collapse may also create fractures and faults that can propagate upward through unconsolidated materials to land surface, where they can be seen as linear features on aerial photographs. Accuracy in locating photolinear features depends on the source photography and the method used to convert images to map projections.
Two photolineament analyses were done in the EW well field, using multiple types of aerial photographs at different scales and spanning a timeframe of more than 50 years. Diodato (1999) identified photolinear features using black and white photographs dating from 1971 at the scale of 1:20,697 using methods described by Lattman (1958), Spratt (1996), and Parizek and Diodato (1995). A map of apparent lineaments and fracture traces was prepared following methods described by Colwell (1960), using black and white photographs dating from 1938 and 1957 at the $1: 20,000$ scale and using a 1995 color infrared image at the 1:40,000 scale (Bob Evans, Southwest Florida Water Management District, written commun., 1999). All identified photolinear features were transferred to the USGS Elfers topographic quadrangle 1:24,000-scale base map using a Bausch \& Lomb zoom-transfer scope.

\section{High-Resolution Seismic-Reflection Surveys}

Land-based high-resolution seismic-reflection surveys were run to investigate subsurface stratigraphic characteristics and discontinuities within the southwestern region of the EW well field with an emphasis on determining if fractures or fracture zones could be identified using methods similar to those used by Odum and others (1997). Four seismic transects were run ranging from 1,356 to $3,612 \mathrm{ft}$, and covering a total length of 8,397 ft (fig. 2). The southwestern part of the well field was selected to corroborate the locations of photolinear features, relate the extent of elevated chloride concentrations to any observed subsurface geologic structure, and collect multiple intersecting seismic transects.

Seismic data were collected using a Mini-SOSIE highresolution seismic-reflection technique (Barbier, 1983; Stephenson and others, 1992), and using 28-Hertz resonantfrequency geophones and a 60-channel seismograph. Three geophones per receiver station were arranged in a cluster (point) array at each station. Stations were spaced $16.4 \mathrm{ft}$ apart. Datacollection parameters were designed to image features with a moderately high degree of resolution 100-800 ft below land surface. Detailed resolution, especially at shallow depth, was sacrificed to obtain deeper penetration.

Noise generated by typical well-field operations (pipeline flow, running well pumps, and underground culverts) combines to variably degrade the strength and clarity of the recorded seismic signal. In some cases, the data quality was improved by removing the noise through processing of the seismic data. In other cases, the noise and associated interference could not be removed sufficiently to improve the data quality. Available geologic data were correlated with seismic data using wells located in close proximity to transects. Types of reflectors and trends in the seismic-reflection data were correlated with lithologic changes or formation boundaries described in the well logs for 5N, 5A, 1, 2, 2A, 4S, 5, 4A, 4, SWI-1S, SWI-1D, 3B, SWI-10S, SWI-10D, and 5B (fig. 2). The stratigraphic and structural features identified in the seismic-reflection data were compared to photolinear features and borehole geophysical logs. 


\section{Effects of Aquifer Heterogeneity on Ground-Water Flow and Chloride Concentrations, West-Central Florida}

\section{Borehole Geophysical Techniques}

Borehole geophysical logs provide information about the stratigraphic, structural, and fluid properties of the hydrogeologic environment. Borehole geophysical data were collected at 13 wells within the study area and were correlated with the seismic-reflection data to identify structural features and lateral continuity of stratigraphic units and water-producing zones within the hydrogeologic framework. Borehole geophysical logging methods followed standards outlined in Keys (1990). Most of the logs were collected using a downhole digital system and tools, although an analog heat-pulse tool and logging system were used for additional flow logging at several sites to compare tools and techniques.

Logging data were collected during three time periods that had different hydrologic conditions: August-September 1998, March-April 1999, and March 2000. The AugustSeptember 1998 period was coincident with the annual rainy season, which is characterized by less ground-water pumping and higher ground-water levels. The March-April 1999 period represented the annual dry season, characterized by greater ground-water pumping rates and lower ground-water levels. The March 2000 period represented a drought period with greater than normal ground-water pumping rates and extremely low ground-water levels.

Caliper and acoustic televiewer logs are useful in identifying fractures, washout zones, and zones of enhanced porosity in the geologic units. Acoustic televiewer logs are used to further characterize borehole conditions, formational character, and porosity type, but at greater resolution than caliper logs. The acoustic televiewer method provides a continuous, 360-degree sonic image of the borehole from which borehole features such as fractures, bedding planes, vugs, and caverns can be identified in the open borehole. The 360-degree view provides a continuous image of any structure intersecting the borehole. Bedding planes and horizontal features appear as flat lines. Fractures or features that intersect the borehole at an angle appear as sinusoidal curves with the amplitude of the curve indicative of relative dip angle. By using the maximum and minimum heights of these curves, the dip angle of identified fractures can be measured. Although the caliper and acoustic televiewer data provide information about the variability in borehole diameter, neither $\log$ was used to infer the presence of water-producing zones or ground-water flow. Caliper and acoustic televiewer logs were compared, and consistent patterns in borehole-diameter changes were used to characterize geologic properties and lateral extent of specific stratigraphic units. Acoustic televiewer logs are limited to boreholes less than 12 in. in diameter. As a result, acoustic televiewer logging was limited to the lower Ocala Limestone and the Avon Park Formation because of substantially enlarged boreholes or washout zones present in the shallow units.

Caliper logs, in combination with other borehole techniques, provide a useful method for estimating the types and size of porosity, especially at the formational scale (Cunningham, 2004a,b). Acoustic caliper logs, when combined with acoustic televiewer data, provided images that could be related to types and extent of porosity. Enlarged borehole conditions do not necessarily indicate effective secondary porosity. Although core data provide a good idea of effective primary porosity or small-scale secondary porosity, the presence of large-scale porosity within an aquifer unit requires additional verification before it can be classified as effective secondary porosity or be used to indicate how and where ground-water movement occurs. In this study, the observations of porosity characteristics using caliper and acoustic televiewer logs were correlated to temperature, flow, and fluid resistivity $\operatorname{logs}$ to evaluate features that were associated with ground-water flow.

Water-quality profiles and apparent water-producing zones were identified using fluid resistivity or fluid conductance and fluid temperature logs. Fluid resistivity logs were converted to specific conductance by dividing 10,000 by the resistivity, in ohm-meters. Specific conductance logs obtained from the same well at different dates were compared to identify temporal variability in ground-water quality. Water-quality samples were collected at discrete depths within the borehole to calibrate the fluid conductance logs. Specific conductance logs without point-sample calibration information were analyzed for trends only.

Flow logs using both heat pulse and electromagnetic (EM) flow meters were collected and compared to determine their suitability in assessing ground-water flow. Ideally, flow logs should be collected under steady-state conditions. Because water levels often fluctuated during logging, however, the most effective method for detecting flow zones in a particular borehole was to collect multiple logs at each well under different conditions.

Flow logs were collected under ambient and pumping conditions, with and without a diverter, and in the trolling and stationary mode. Borehole flow was constricted by using a diverter to increase flow across the sensor and, therefore, increase the sensitivity of the measurement. The best data were obtained using a large diverter and high gain settings. These conditions reduced the effects of borehole diameter, thus providing more consistent borehole conditions for flow measurements. The EM flow log tool was preferred for flow logging because it contains specific conductance and temperature sensors, which are useful in identifying flow related to water-quality changes. The heat-pulse flow meter was used whenever the EM flow log tool was inoperable.

In west-central Florida, washout zones occur during well construction where lithologic units are not competent enough to maintain a consistent borehole diameter. Borehole volume is a critical element in obtaining accurate fluid-flow measurements. Variable borehole diameter alters the cross-sectional area of the borehole and changes the borehole volume. Stationary flow measurements were made at discrete points in the borehole so 
that the borehole volume could be held constant. Flow logs collected while the probe was moving up or down the borehole (trolling or moving) are affected by the changing borehole diameter, which affects the apparent velocity of borehole fluids. Both trolling and stationary logs were corrected for borehole-volume effects by calibrating to measurements made in the well casing and recalculating flow using diameter measurements for borehole volumes obtained from the caliper $\operatorname{logs}$. Associated changes in water quality, observed using fluid conductance logs, were related to measured flow and geologic structure to evaluate where ground-water flow occurs.

\section{Water-Quality Data Collection and Analysis}

Historical and contemporary water-quality data were used to analyze trends and to document the spatial and temporal changes in ground-water quality. Isotopic samples for delta oxygen-18 $\left(\delta^{18} \mathrm{O}\right)$, delta deuterium $(\delta \mathrm{D})$ and strontium $87 /$ strontium $86\left({ }^{87} \mathrm{Sr} /{ }^{86} \mathrm{Sr}\right)$, were analyzed to provide further chemical evidence of sources and mixing mechanisms for ground water. The $\delta \mathrm{D}$ and $\delta^{18} \mathrm{O}$ data, in conjunction with chloride concentrations, were used to help identify sources of salinity. Strontium isotopic data were used to identify sources of salinity, ground-water mixing, and relative ages of aquifer materials that contribute strontium to ground water. Strontium isotopes $\left({ }^{87} \mathrm{Sr} /{ }^{86} \mathrm{Sr}\right)$ have varied in seawater over geologic time, so the measured ratio of ${ }^{87} \mathrm{Sr} /{ }^{86} \mathrm{Sr}$ in water can be valuable for distinguishing sources and ages of aquifer materials in contact with ground water.

Water-quality data were collected from 23 wells. Samples were collected from the 13 wells logged during this study and from 10 additional wells selected to represent possible chloride sources and ground-water mixing end-members within the study area. For quality-assurance purposes, duplicate water samples were collected for 10 percent of the samples. Well volume was purged three times and water samples were collected after temperature, specific conductance, $\mathrm{pH}$, and dissolved oxygen measurements had stabilized.

All ground-water samples were collected and analyzed for major ions using standard USGS methods (Wilde and Radtke, 1998). Temperature, specific conductance, $\mathrm{pH}$, and dissolved oxygen were monitored using a flow-through chamber. Alkalinity was determined in the field by titration with sulfuric acid. Strontium samples and two prepared ${ }^{87} \mathrm{Sr} /{ }^{86} \mathrm{Sr}$ standards were analyzed at the University of Florida according to methods discussed by Pin and Bassin (1992). Split samples were run for 4 of the total (22) ${ }^{87} \mathrm{Sr} /{ }^{86} \mathrm{Sr}$ samples. Unfiltered water samples were collected in poly seal-capped glass bottles for $\delta \mathrm{D}$ and $\delta^{18} \mathrm{O}$ analysis.

Continuous water-level and specific-conductance data at fixed depths in eight boreholes were collected by the USGS from 1993 to 2000. During this study, three new sites (wells 2A, 3B, and 201-M) were instrumented with data loggers to continuously monitor water levels and specific conductance. Temperature-compensated specific conductance probes were installed at two fixed depths in each well.

\section{Hydrogeology}

Ground-water flow patterns are related to lithologic and hydraulic properties of the aquifer and to hydraulic gradients. Within the EW well field, ground-water flow patterns mainly are controlled by the hydraulic properties of the geologic units, pumping rates, and the location of the saltwater/freshwater interface. These factors also affect the ground-water quality within and near the EW well field.

The distribution of hydraulic properties is complex. Lithologic differences and structural features create heterogeneous distributions of porosity and permeability. Florida is underlain by carbonate rocks that have been altered by karst processes. Limestone and dolomite units are variably riddled with fractures, enlarged bedding planes and geologic contacts, vugs, and caverns of various sizes (Hickey, 1982; Robinson, 1995; Knochenmus and Robinson, 1996). Structural features formed as a result of dissolution collapse or fractures associated with larger structural mechanisms create zones along which water moves preferentially. Features indicating the presence of preferential flow networks within the study area include fractures, lineaments, and collapsed dissolution features, which can extend across stratigraphic units, thereby facilitating groundwater flow in multiple directions. Well-developed networks of conduits and preferred flow zones facilitate rapid lateral and vertical mixing of ground water. Clays and fine-grained materials form confining units or produce semiconfined conditions, impeding ground-water flow.

\section{Hydrogeologic Framework}

The hydrogeologic units underlying the study area are, in descending order, the surficial aquifer system (SAS), the intermediate confining unit (ICU), the Upper Floridan aquifer (UFA), and the middle confining unit (MCU) (fig. 3). These units generally correspond to the stratigraphic units identified in the study area (fig. 4). The uppermost water-bearing unit, the SAS, is predominantly sand. The sand deposits are underlain by ICU clays (primarily of the Hawthorn Group) that separate the UFA from the SAS. The degree of confinement between the SAS and UFA varies depending on the clay content within the undifferentiated surficial deposits and the Tampa Member of the Hawthorn Group. The UFA is a multilayered sequence of relatively high and low permeability carbonate units. The UFA is confined below by the MCU where evaporite minerals are present within the carbonate units, thereby reducing the permeability. Formation names are based upon the geologic definitions of Scott (1988) and are equivalent to those used by the Florida Geological Survey. Lithologic descriptions are primarily from Green and others (1995). 


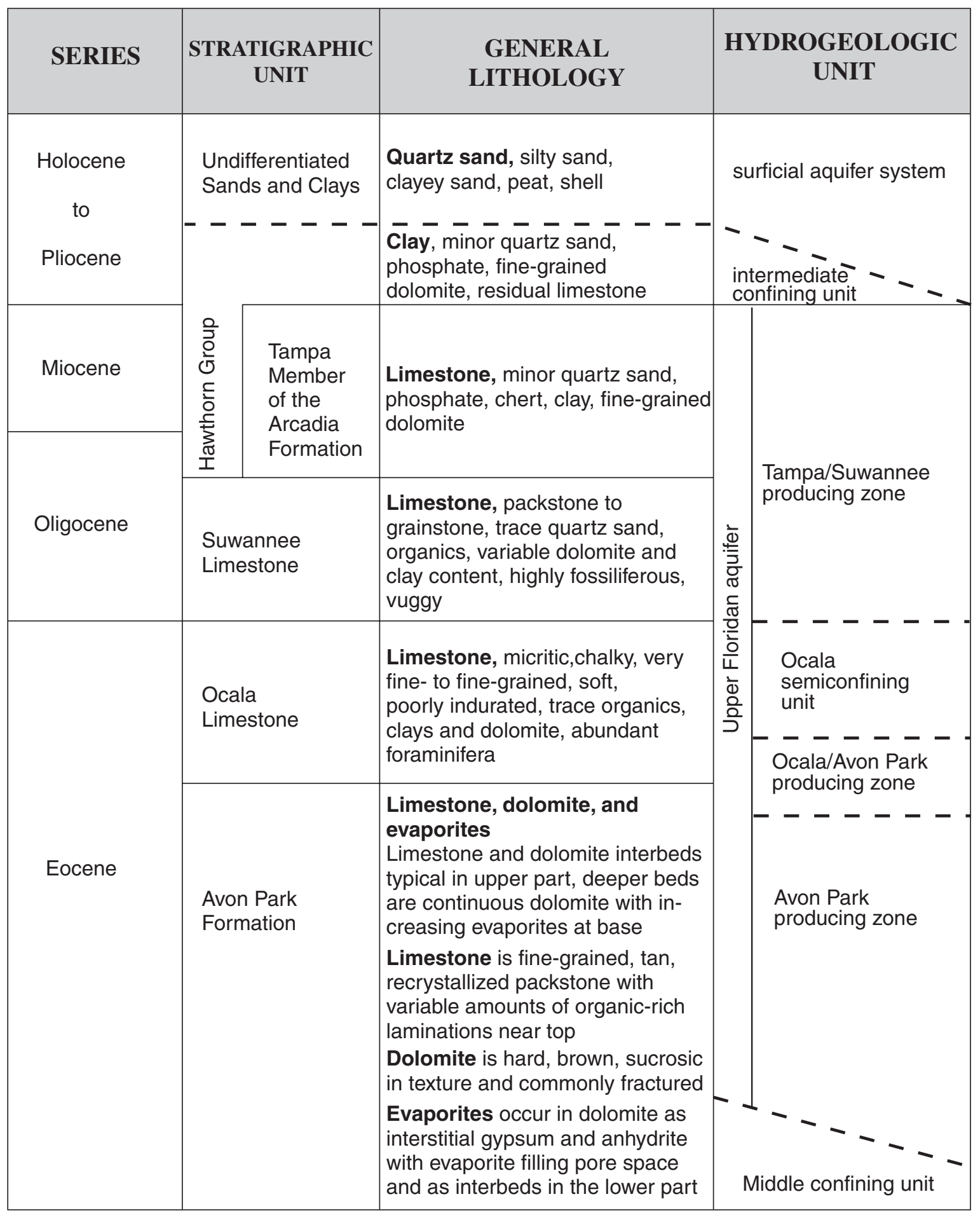

Figure 3. Generalized hydrostratigraphy for the study area. Modified from Black, Crow, and Eidsness, Inc. (1970); Ryder (1981); Trommer (1992); Green and others (1995); Southwest Florida Water Management District (1996a,b); Arthur and others (2001). 


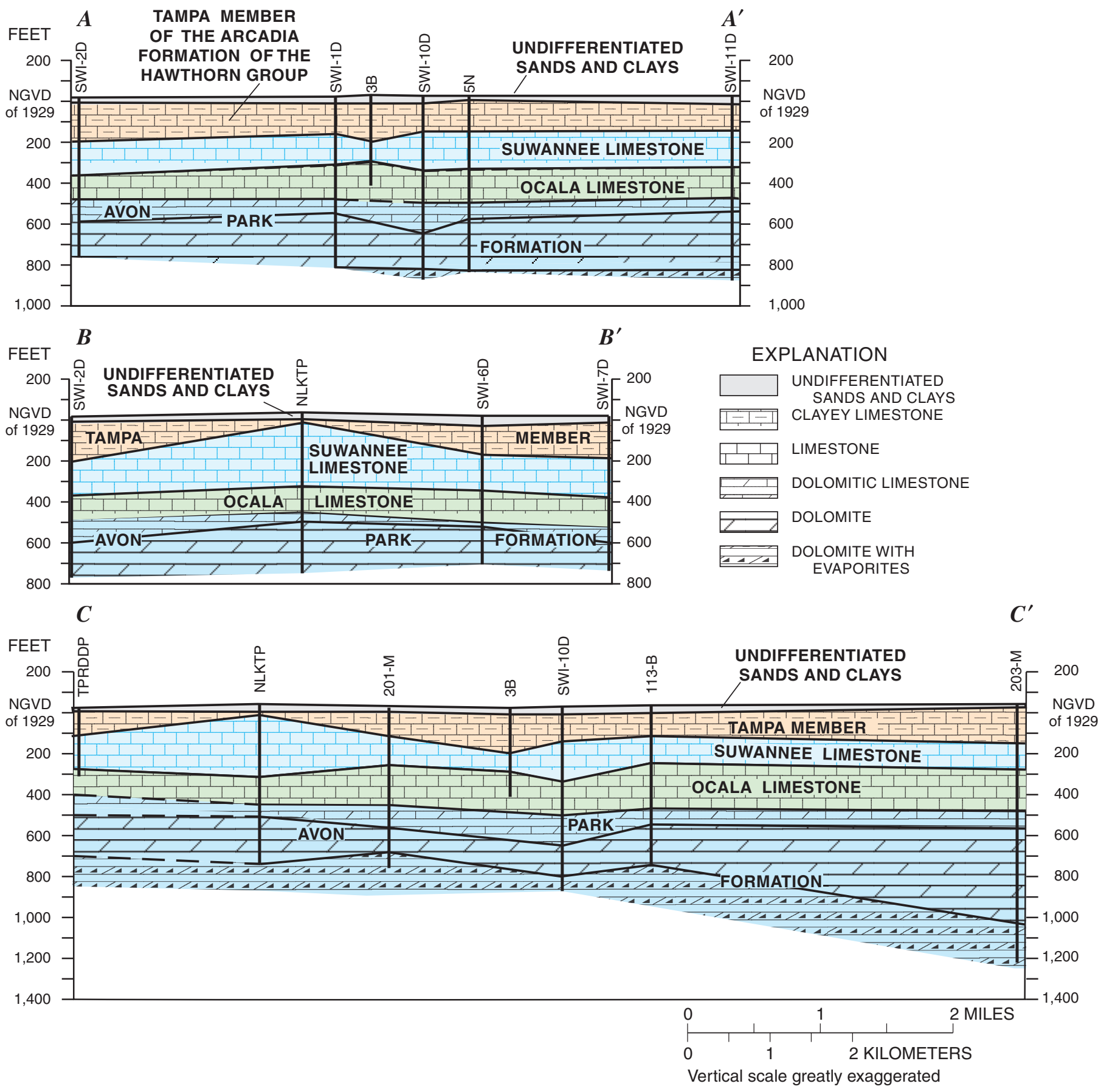

Figure 4. Stratigraphic sections $A-A^{\prime}, B-B^{\prime}$, and $C-C^{\prime}$ through the study area. Locations of sections are shown in fig. 2. Stratigraphic contacts are based on geologic data from Black, Crow, and Eidsness, Inc. (1970); Gee and Jenson, Inc. (1981a,b); Nettles and Vandor, Inc. (1983); Nettles and Associates, Inc. (1989, 1991b,c; 1992b,c). 


\section{Effects of Aquifer Heterogeneity on Ground-Water Flow and Chloride Concentrations, West-Central Florida}

\section{Surficial Aquifer System}

The SAS consists of fine to very fine quartz sand, silt, clayey sand, and shell fragments. In the vicinity of the study area, the SAS is thickest along the margins of Lake Tarpon, west of the EW well field, where the SAS consists of paleodune deposits. The SAS generally is 10 to $50 \mathrm{ft}$ thick but can be more than $80 \mathrm{ft}$ thick where paleodune deposits are present (Green and others, 1995). In the wells used for stratigraphic control in this study, the measured thickness of the SAS ranges from 12 to $50 \mathrm{ft}$ with an average thickness of $32 \mathrm{ft}$. Although the SAS is seldom used for potable water supplies, it provides recharge to lakes, ponds, and the UFA.

\section{Intermediate Confining Unit}

The low permeability ICU comprises undifferentiated siliciclastic sediments of the Hawthorn Group, which consists of predominantly clay minerals with minor amounts of quartz sand, phosphate, fine-grained dolomite, and some residual limestone. The ICU is less than $25 \mathrm{ft}$ thick within the study area (Green and others, 1995). In the northeastern part of the EW well field, where the ICU thins, the UFA is less confined and may receive direct recharge through sands of the SAS. Sinkholes are common in this region, and breaches occurring in the ICU can reduce the effective confinement in localized areas (Sinclair and others, 1985; Green, and others, 1995; Diodato, 1999). A sinkhole along the western shore of Lake Tarpon is connected to Spring Bayou in Tarpon Springs by way of a subsurface conduit within the limestone (Heath and Smith, 1954). Where the ICU thickens near the western edge of the EW well field, the water table mounds (Ryder and Mills, 1977a,b; Wolansky and others, 1978b).

\section{Upper Floridan Aquifer}

The UFA is a thick sequence of limestone, dolomitic limestone, dolomite, and interbedded dolomite and evaporites. The UFA includes, in descending order from youngest to oldest, the following geologic units: the Tampa Member of the Hawthorn Group, the Suwannee Limestone, the Ocala Limestone, and the Avon Park Formation. These carbonate units vary in texture, lithology, and hydraulic properties (figs. 3, 5), reflecting the various types of carbonate sedimentary depositional environments of west-central Florida.

The Tampa Member ranges from 15 to $200 \mathrm{ft}$ thick, but averages about $140 \mathrm{ft}$ thick within the study area. The Tampa Member has a highly variable lithology that is predominantly limestone, but also contains quartz sand, clay, phosphate, chert, and fine-grained dolomite (fig. 3).

The Suwannee Limestone, of Early Oligocene age, is a shallow-water carbonate characterized by cream to tan, crystalline, biomicritic packstone to grainstone that contains quartz sand, variable dolomite, clay and other minor impurities. The terms grainstone, packstone, and wackestone (Dunham, 1962) refer to granular carbonates with no mud, grain supported with some mud, and predominantly mud (mud supported but more than 10 percent grains), respectively. The Suwannee Limestone is highly fossiliferous, containing gastropods, pelecypods, echinoids, miliolids, and other benthic formaminifera, and can be vuggy due to the abundant gastropod and pelecypod casts and molds. The Suwannee Limestone consists of three major depositional megacycles that are interrupted by repeated subaerially exposed surfaces (Hammes, 1992); grain size generally increases in the upper part of each cycle. The subaerially exposed surfaces increase in frequency within the uppermost megacycle, ultimately marking the end of Suwannee deposition. During the exposure periods, extensive karst features, enhanced porosity, and caliche crusts developed that are characteristic features of the Suwannee Limestone (Hammes, 1992).

In the study area, the top of the Suwannee Limestone generally is at 150 to $200 \mathrm{ft}$ below NGVD of 1929 and extends to nearly $400 \mathrm{ft}$ below NGVD of 1929; the average thickness of the unit is $160 \mathrm{ft}$. Hammes (1992) found that variations in thickness are influenced by proximity to large-scale structural features of tectonic origin. The gamma ray geophysical log typically shows high background deflection for the Suwannee Limestone; the Suwannee-Ocala Limestone contact is readily distinguishable on the log by the sharp drop in gamma activity observed in the underlying Ocala Limestone (Green and others, 1995) (fig. 5).

The Ocala Limestone represents 4.5 million years of continuous subaqueous carbonate sedimentation during the Late Eocene (Carter and others, 1989; Loizeaux, 1995). The irregular upper surface of the Ocala Limestone is characterized by onlapping of the Suwannee Limestone, indicating a period of nondeposition and associated erosion, which is believed to have been associated with a drop in sea level, although evidence of subaerial exposure is not present (Loizeaux, 1995). The Ocala Limestone comprises 12 sedimentary facies within 3 major identifiable sequences that, together, reflect an increase in water depth upward in the sedimentary record.

The top of the Ocala Limestone is at an elevation of approximately 300 to $470 \mathrm{ft}$ below NGVD of 1929 , and the unit has an average thickness of $170 \mathrm{ft}$ within the study area. The Ocala Limestone is a pure carbonate unit that ranges from a fine-grained pelagic wackestone to a mixed skeletal grainstone with substantial variation in grain type, size, cementation, and porosity (Loizeaux, 1995). The unit is characterized by soft to semi-indurated micritic limestone containing abundant foraminifera (Camerina sp.) and echinoid fragments loosely bound in the limestone matrix. The upper $120 \mathrm{ft}$ of the Ocala Limestone consists mostly of foraminifera, and corresponds to a low gamma-ray deflection on the geophysical log. The foraminifera-rich sections are very poorly indurated, appearing in well cuttings as carbonate sand, and causing severe caving problems during drilling. Caliper logs typically show distinctive patterns where the Ocala Limestone is either highly variable or has been washed out by drilling activity (fig. 5). Dolomitic lenses increase in the lower part of the Ocala Limestone. 
The contact between the Ocala Limestone and the underlying Avon Park Formation is an unconformity resulting from subaerial exposure of the Avon Park. The contact commonly is associated with a distinctive black to brown hardpan that contains poorly cemented, friable organic silts and silica sand, which correspond to a large gamma-ray deflection on the geophysical log (fig. 5).
The underlying Avon Park Formation is a peritidal carbonate with associated evaporites that was dolomitized contemporaneously with deposition under arid conditions and intermittently restricted seawater circulation. Lithologic data indicate that the unit was deposited in very shallow marine water with deposits containing cyclic tidal-flat and shoaling-upward sequences alternating with shallow, open-marine carbonate units. The typical

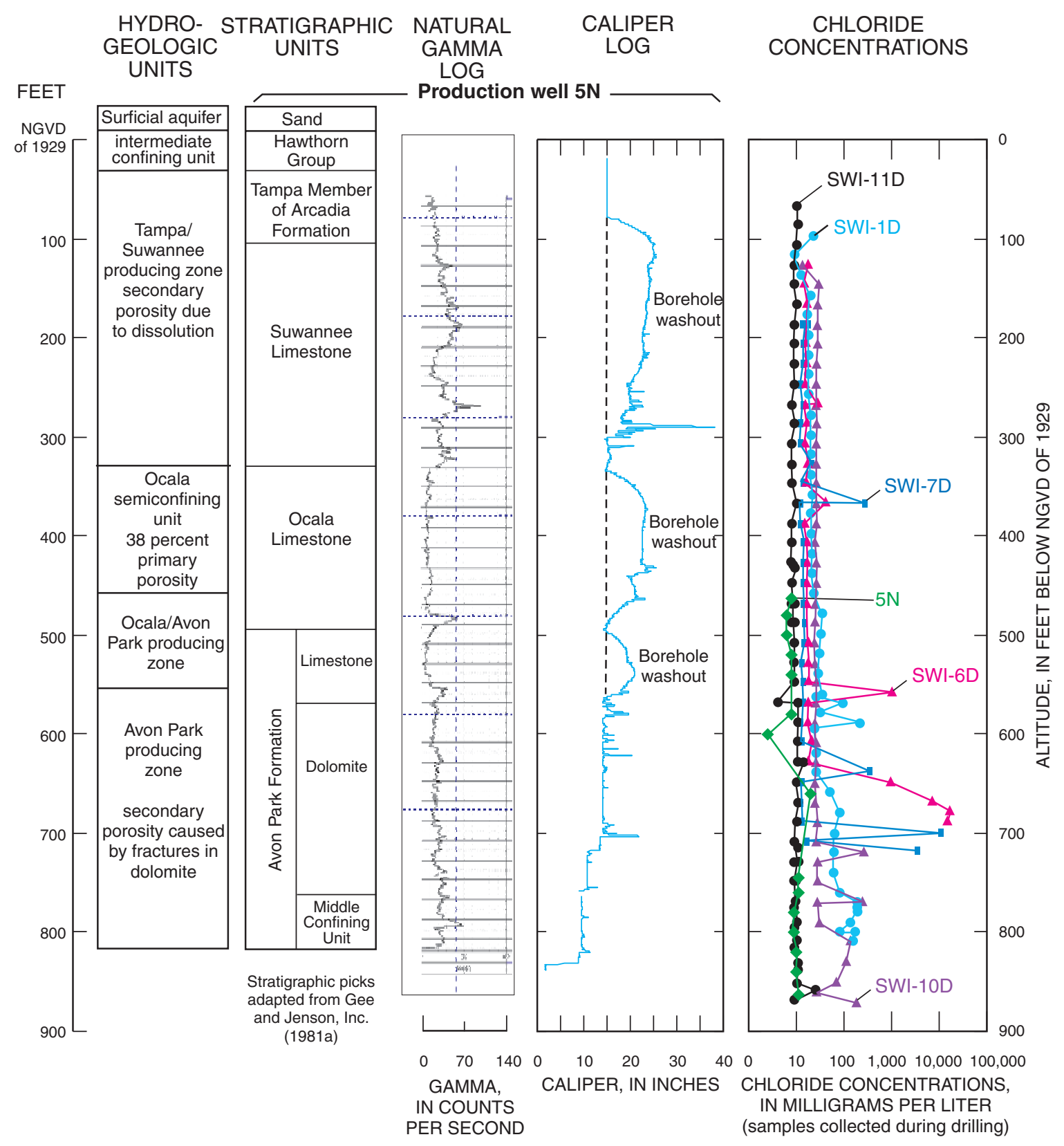

Figure 5. Detailed hydrostratigraphic column of the study area with representative geophysical logs and chloride concentrations with depth. Based on data from Black, Crow, and Eidsness, Inc. (1970); Geraghty \& Miller Inc. (1976b); Hickey (1982); Miller (1986); Knochenmus and Thompson (1991); Trommer (1992); Green, and others (1995); Knochenmus and Robinson (1996); Knochenmus and Swenson (1996); Southwest Florida Water Management District (1996a,b, 2000a); Broska and Barnette (1999); and Metz and Sacks (2001). 
shoaling-upward sequences include mudstone, packstone/ grainstone overlain by mudstone wackestone, algal laminated mudstone, and some nodular gypsum and(or) anhydrite. A limestone unit with organic-rich layers (peat) and abundant seagrass fossils generally characterizes the upper part of the Avon Park Formation. Where present, the limestone consists of a brown, well-lithified, biosparite and the foraminifera Dictyoconus americanus. The dolomite is hard, brown, and massive. Toward the base of the Avon Park Formation, interstitial infilling of void spaces with evaporitic gypsum or anhydrite increases. Although some short-lived subaerial exposure was common during deposition, no evidence of extensive subaerial diagenesis has been documented. The lower part of the Avon Park Formation is almost completely dolomitized and only the upper part contains limestone that has not been dolomitized (Cander, 1991).

\section{Middle Confining Unit}

The MCU is present where gypsum and anhydrite infill interstitial voids and form continuous beds within the dolomite units of the Avon Park Formation. Data describing the regional extent and lateral continuity of this hydrologic unit are sparse, but the MCU is present at approximately $1,100 \mathrm{ft}$ below land surface in west-central Florida and pinches out eastward toward the middle of the Florida Peninsula (Miller, 1986; Hickey, 1990). The intergranular evaporites substantially reduce the permeability of the Avon Park Formation and restrict ground-water flow (Ryder, 1981, 1985; Miller, 1986, Southwest Florida Water Management District, 1996a,b, 2000a). The presence of excess calcium, sulfate, and strontium in downdip parts of the UFA, however, indicate that freshwater interacts and dissolves the interstitial evaporites that form the MCU (Cander, 1991). The MCU is considered to be the base of the UFA, and its presence is the lower limit of hydrologic units pertinent to this study.

\section{Structural Characteristics and Lateral Continuity of Hydrogeologic Units}

Structural characteristics and lateral continuity of hydrogeologic units were investigated to determine how these features affect ground-water movement. The lateral continuity of stratigraphic units, water-producing zones, and confining units within the hydrogeologic framework were evaluated by correlating data from photolineament analyses, land-based high-resolution seismic-reflection surveys, and borehole geophysical logs. These three methods resolve structural features at different scales, and results were compared to determine the existence and location of structural features.

Photolineaments within and near the EW well field were identified by Spechler (1983) and Nettles and Vandor, Inc. (1988b). Spechler (1983) identified several large-scale photolineaments within the region, building upon work by Vernon (1951). Nettles and Vandor, Inc.(1988b) identified a sparse number of large-scale photolinear features that trend northeastsouthwest through the well field. In a study at the Cross Bar Ranch well field located north of the EW well field, 618 photolinear features of various lengths were identified, and more than 60 percent of the photolineaments showed a bimodal distribution in two dominant orientations: northwest-southeast and northeast-southwest (Williams, 1985).

Recent work by Diodato (1999) and Evans (Bob Evans, Southwest Florida Water Management District, written commun., 1999) identified 33 and 103 photolinear features, respectively, within the EW well field and surrounding area. Each used photographs at different scales but followed similar methods in transferring interpreted photolinear features to base maps. Methods for the photolineament analysis conducted by Nettles and Vandor Inc. (1988b) could not be determined and were not included in the analysis presented here. The same photolineaments were not identified by Diodato or Evans, nor do they share a similar dominant directional orientation (fig. 6). Photolineaments identified by Evans did not have a dominant direction of orientation; those identified by Diodato showed a nearly bimodal distribution of cumulative length and dominant orientation northeast-southwest, similar to one of the modes determined by Williams (1985). The northeast-southwest direction of photolinear features also corresponds to the observed increases in chloride concentrations found in ground-water samples from the southwestern part of the EW well field.

The origin of photolinear features likely affects their length and orientation. Williams (1985) observed that joints induced by earth tides result in short photolinear features, whereas large-scale tectonic structural origins create longer photolinear features. Comparing the Diodato and Evans data demonstrates that differences in the number and frequency of observed photolinear features may correspond to differences in origin, scale, source photography, and interpretation methods. The similarities between Williams (1985), Diodato (1999), and the orientation of chloride concentrations, however, indicate that structural control may exist, and is reflected as discernable photolinear features at land surface.

Geologic structure was investigated using land-based high-resolution seismic-reflection survey methods. Four seismicreflection transects, run in the southwestern section of the EW well field, correlated well with geologic borehole data (fig. 7). Dolomite units, which are denser than limestone units, were detected as well-defined, high-amplitude reflectors in all four transects. Friable or soft limestone noted in geologic logs correlated, respectively, with discontinuities or very faint to nonexistent reflectors in some of the records. Records for transects 1 and 4 were of the highest quality and had good geologic information for correlation (fig. 7). The reflector corresponding to dolomite (about $300 \mathrm{ft}$ below land surface) appeared clearly in the record for transect 4 and corresponds to dolomite noted in lithologic logs for wells SWI-10S and 10D (fig. 7B). Although geologic control was limited to shallow depths along transects 2 and 3, the laterally discontinuous presence of the dolomite reflector corresponded to the intermittent presence noted in other lithologic logs. The dolomite unit appears to be missing in the seismic record of transect 2 between monitoring well 3B and production well 4A, and was not noted in either of the lithologic logs. 


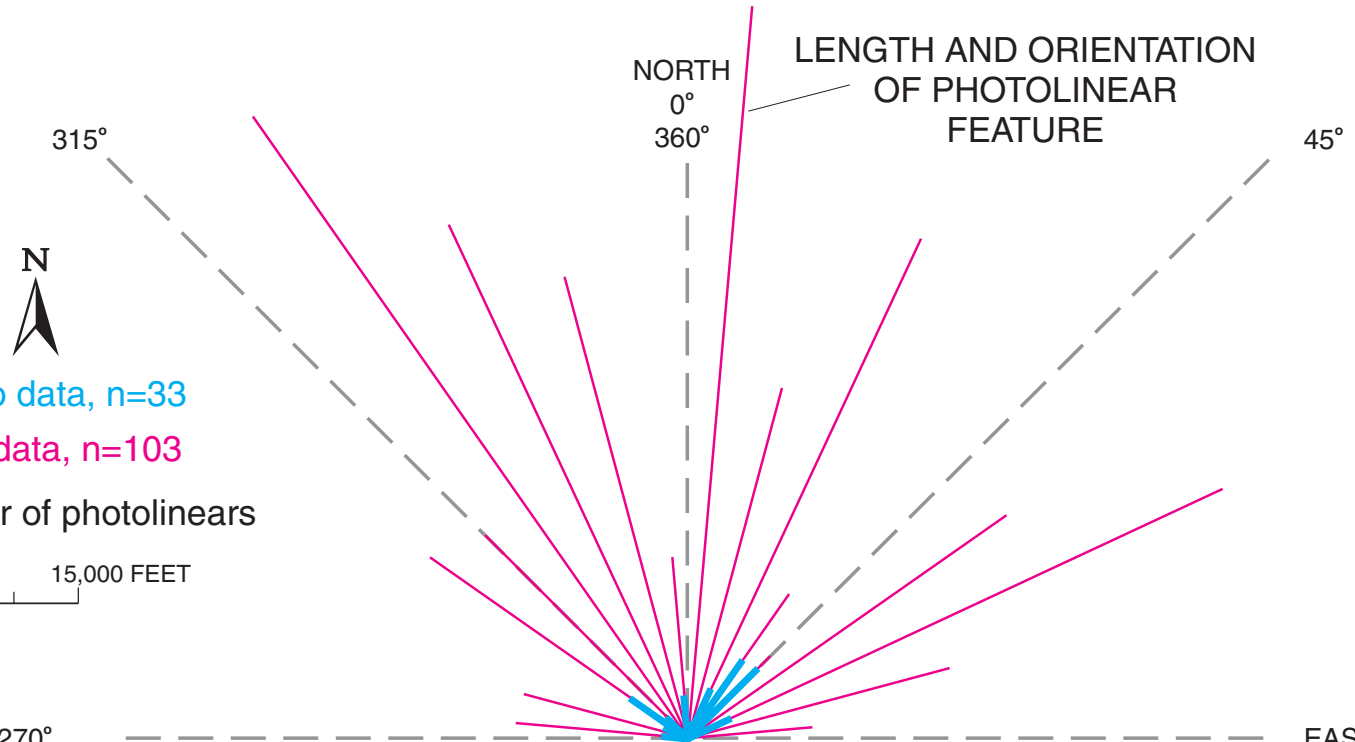

WEST $270^{\circ}$
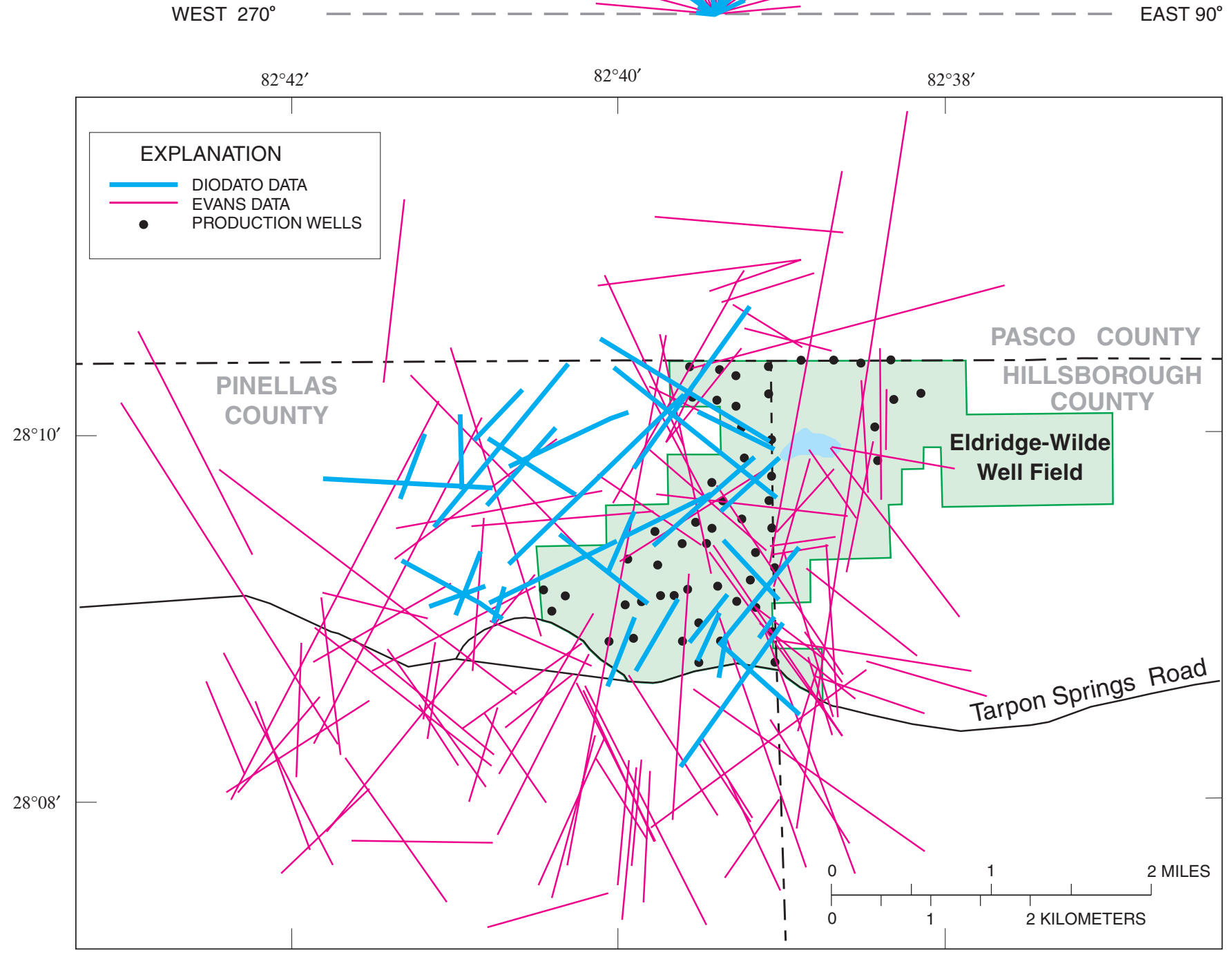

Figure 6. Location and orientation of fracture traces and photolineaments interpreted from aerial photographs. Modified from Diodato (1999) and Bob Evans, Southwest Florida Water Management District, written commun. (1999). 
A

\section{TRANSECT 1}

South

North
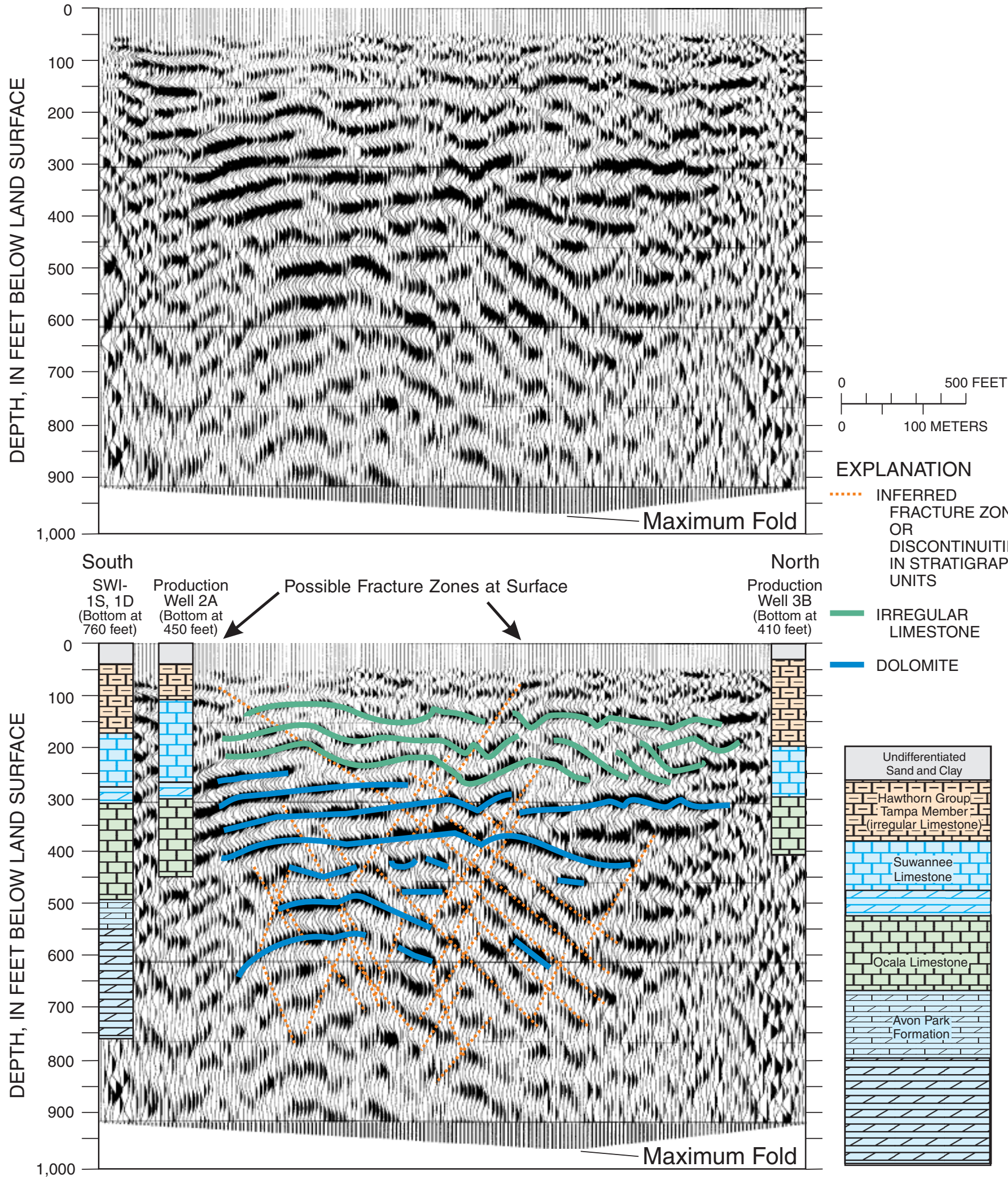

\section{EXPLANATION}

\section{...... INFERRED}

FRACTURE ZONES OR

DISCONTINUITIES

IN STRATIGRAPHIC

UNITS
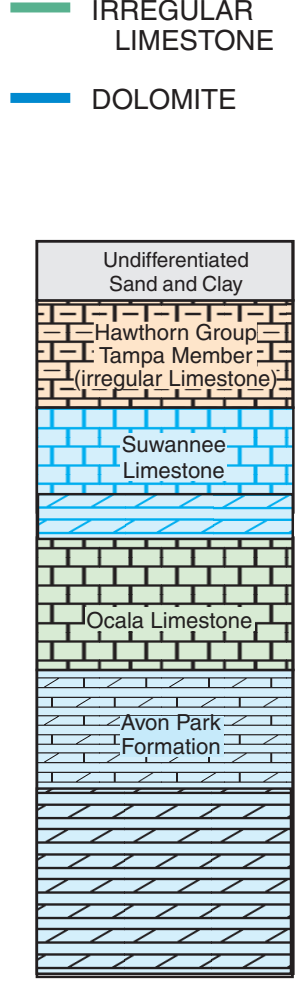

Figure 7. Seismic-reflection data for transects 1 (fig. 7A) and 4 (fig. 7B), with geologic correlation and interpretations of subsurface features. Locations of transects and control wells are shown in fig. 2. 
B

\section{TRANSECT 4}

South

North
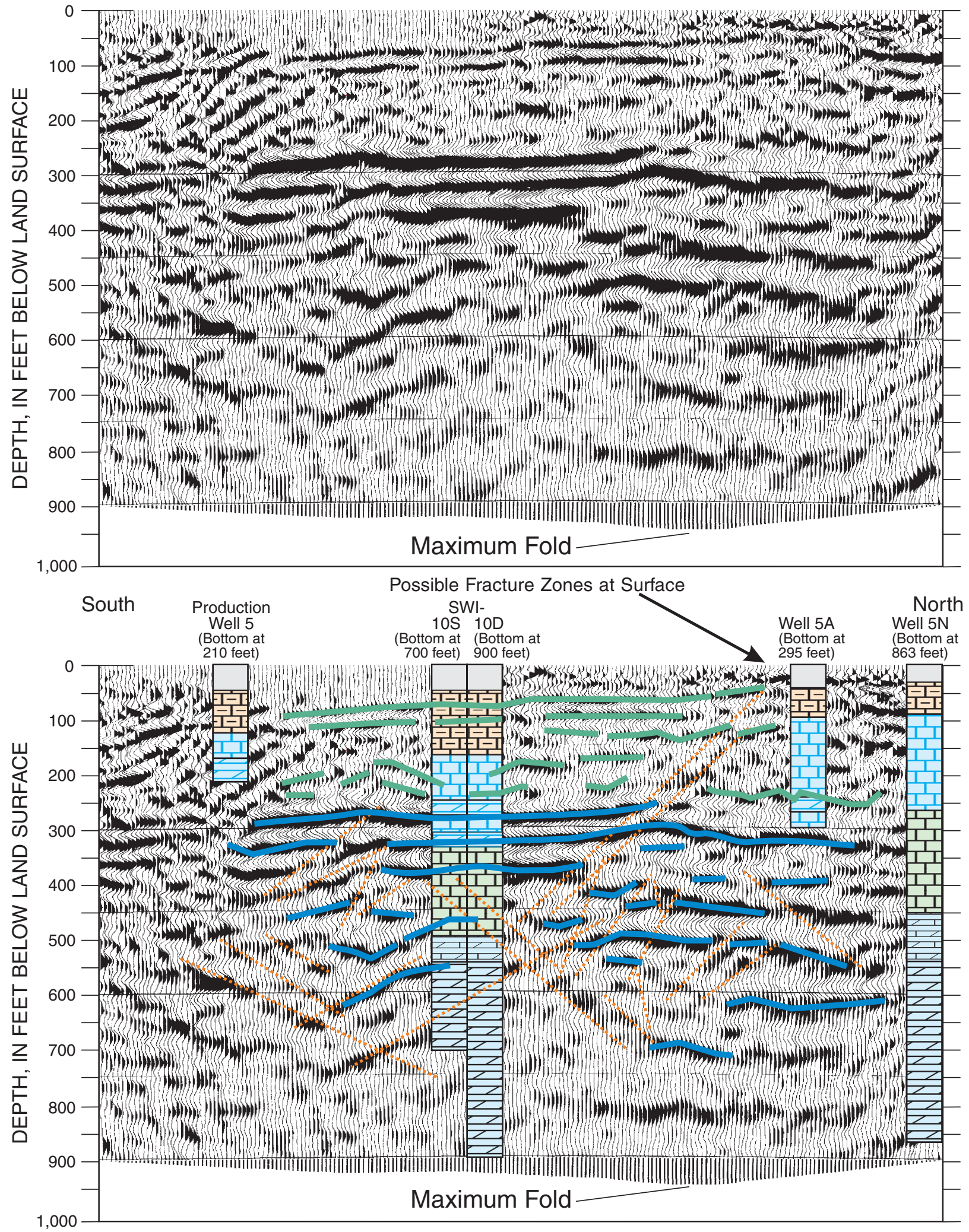

Figure 7. Seismic-reflection data for transects 1 (fig. 7A) and 4 (fig. 7B), with geologic correlation and interpretations of subsurface features. Locations of transects and control wells are shown in fig. 2. (Continued) 


\section{Effects of Aquifer Heterogeneity on Ground-Water Flow and Chloride Concentrations, West-Central Florida}

Along transects 1 and 4, dolomite present at the contact between the Suwannee and the Ocala Limestones correlated with a persistent, but intermittent reflector that divided the seismic data into two distinct seismic-data types. Above the lithologic contact, seismic-reflection characteristics include reflectors that are undulatory, discontinuous, and poorly defined, indicating an irregular karstic limestone. Below the contact, high-angle, high-amplitude, and discontinuous horizontal reflectors correspond to the lower Ocala Limestone and the Avon Park Formation. The undulatory reflectors observed in the seismic-reflection data correspond to the Suwannee Limestone and indicate dissolution mechanisms. Dissolution of bedding planes and the formation of caverns generally are best developed within the Suwannee Limestone (Hammes, 1992). The distinct reflection pattern in the seismic data for the Ocala Limestone and Avon Park Formation indicates that fractures associated with dolomitic units produce an identifiable seismic signature. Fractures are less common in the Tampa Member and Suwannee Limestone, but commonly are found in the lower Ocala Limestone and the Avon Park Formation (Gee and Jenson, Inc., 1981a).

Fractures or stratigraphic zones containing fractures were inferred on the seismic-reflection data where angular reflectors and disruption and discontinuities of reflectors were noted (fig. 7). Some of the inferred fractures or discontinuities were tentatively identified extending upward into the most shallow carbonate units (less than $50 \mathrm{ft}$ below land surface), particularly in the area between wells 3B and 4A. Although photolinear features do not appear to cross transect 4 , several photolinear features cross transects 1,2 , and 3 . Several features are in the vicinity of wells $2 \mathrm{~A}, 3 \mathrm{~B}, 4 \mathrm{~S}$, and $4 \mathrm{~A}$. Fractures inferred in transects 2 and 3 also appear to extend into shallow geologic units. Along transect 4, the inferred fractures are more limited to the Avon Park Formation.

Fractures observed in the acoustic televiewer data corresponded to the change in the character of the seismic-reflection data. Individual fractures and caverns identified on the acoustic televiewer logs from selected wells in the lower Ocala Limestone and the Avon Park Formation are shown in figure 8. Fractures observed in the acoustic televiewer logs ranged from nearly horizontal to nearly vertical ( 85 degrees). Based on the sesimicreflection surveys and acoustic televiewer data, structural disruption of laterally continuous units most likely occurs when the units are intersected by fractures. Fractures appear to dominate the lower part of the Ocala Limestone and the Avon Park Formation. The presence of individual fractures within the upper Ocala and much of the Suwannee Limestones could not be determined using the acoustic televiewer tool because the boreholes were enlarged by washout of these less competent units. The seismicreflection data, however, indicate that fractures may extend upward into both the Ocala and Suwannee Limestones.

Structural features (photolineaments, fractures, or enlarged caverns) create pathways that could enhance groundwater flow and allow deep ground water to move into shallow aquifers. Sinkhole occurrence, water-quality changes, and increased specific capacities of wells tend to align along photo- lineaments, providing further evidence that deep structural features may be important in controlling ground-water flow patterns (Nettles and Vandor, Inc., 1988a,b; Diodato, 1999).

Fractures and other structural features may create preferential flow paths that cross stratigraphic units, connecting deep and shallow flow zones within the aquifer. The lateral continuity of the dolomite unit at the base of the Suwannee Limestone may also be an important control with respect to ground-water flow, because abrupt changes in lithology can create zones along which ground water moves preferentially.

\section{Delineation and Hydraulic Properties of Permeable Zones}

Hydraulic properties of the UFA, including porosity, hydraulic conductivity, transmissivity, and specific capacity were compiled from published aquifer tests within and near the study area. These data reflect the hydraulic properties for the entire UFA and for specific individual stratigraphic units (figs. 3, 5; table 2). In this study, these properties were correlated with features identified in the seismic-reflection data and the acoustic televiewer and caliper logs to determine how structural features influence hydraulic properties of the hydrogeologic units.

The heterogeneous distribution of permeability within the UFA reflects variations in lithologic characteristics, postdepositional alterations, lateral continuity of units, and structural features. Within the study area, the UFA comprises four distinct hydrogeologic units: the Tampa/Suwannee producing zone, the Ocala semiconfining unit, the Ocala/Avon Park producing zone, and the Avon Park producing zone (fig. 5). Generally, permeability ranges from moderate to high in the Tampa/ Suwannee producing zone to very high in the Avon Park producing zone (fig. 9). Wells in west-central Florida with open intervals that span varying depths within the UFA have transmissivity values that range from 1,900 to more than 920,000 $\mathrm{ft}^{2} / \mathrm{d}$, with a maximum value of $1,200,000 \mathrm{ft}^{2} / \mathrm{d}$ (Ryder, 1981; Dames and Moore, 1988; CH2M Hill, Inc., 1990a,b; Southwest Florida Water Management District, 1996a,b, 2000a). Transmissivity within the fractured dolomites of the Avon Park producing zone can be greater than $800,000 \mathrm{ft}^{2} / \mathrm{d}$. Near or within the EW well field, published estimates of transmissivity values for partial thicknesses of the UFA (within the TampaSuwannee Limestone and the Suwannee-Ocala Limestones) range from 35,400 to $58,800 \mathrm{ft}^{2} / \mathrm{d}$. Transmissivity values for the entire thickness of the UFA in this same area range from 55,100 to $109,000 \mathrm{ft}^{2} / \mathrm{d}$, reflecting the influence of the highly transmissive Avon Park producing zone (Southwest Florida Water Management District, 1996a,b, 2000a) (fig. 9, table 2). The overall permeability of the UFA mainly reflects the contributions from discrete permeable zones within the UFA. The Ocala semiconfining unit, with transmissivity values ranging from 3.8 to $1,000 \mathrm{ft}^{2} / \mathrm{d}$, generally restricts vertical movement between the more permeable units, although structural features and discontinuities may locally provide hydraulic connections between the more permeable zones. 


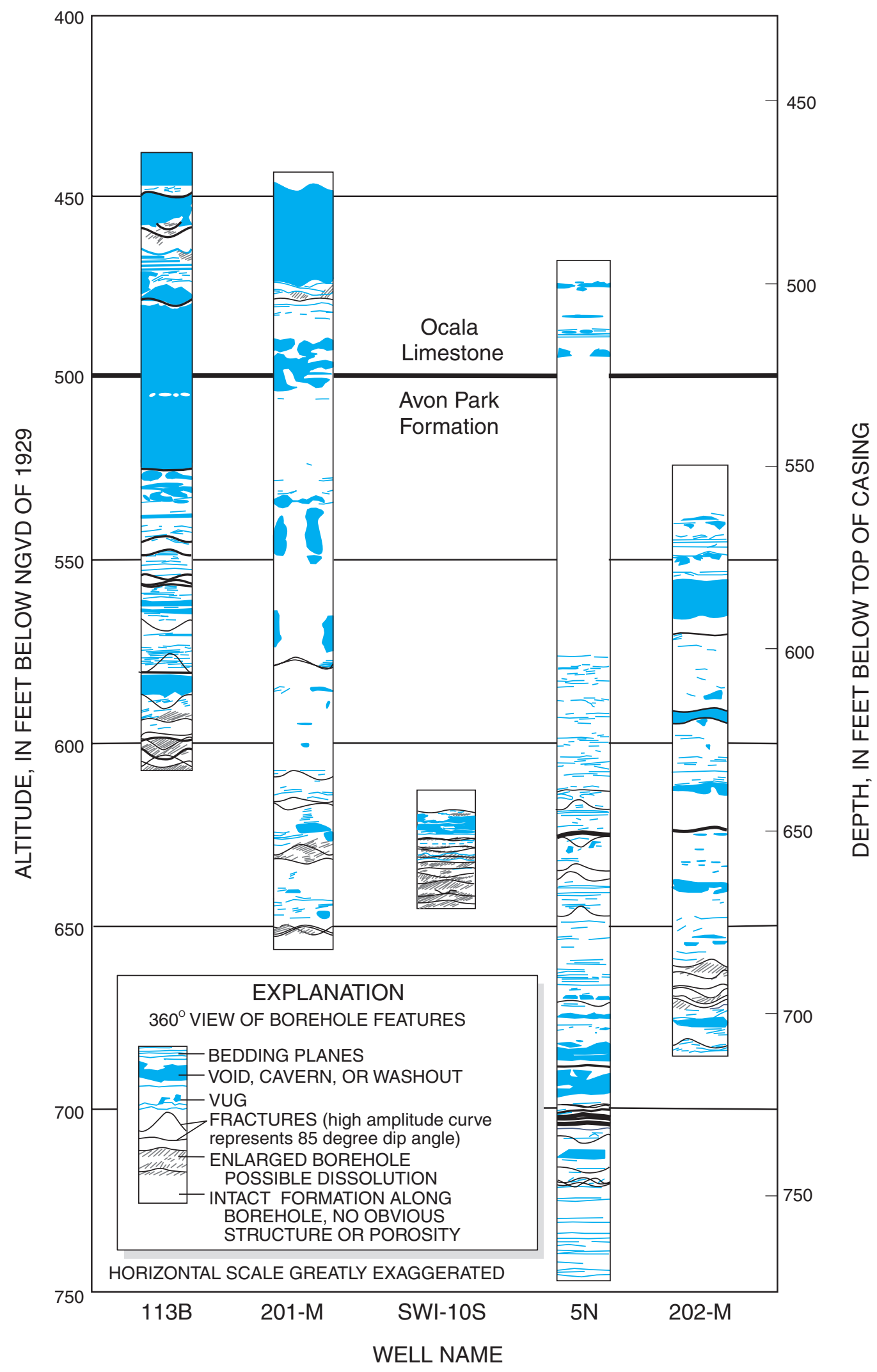

Figure 8. Acoustic televiewer log interpretations for selected boreholes located within the study area. 
Table 2. Transmissivity values for selected depth intervals and specific stratigraphic units of the Upper Floridan aquifer within or near the Eldridge-Wilde well field.

[ft, feet; bls, below land surface; $\mathrm{ft}^{2} / \mathrm{d}$, feet squared per day; A, aquifer test; P, packer test. Data compiled from Southwest Florida Water Management District (SWFWMD), 1996a; 2000a]

\begin{tabular}{|c|c|c|c|c|c|c|}
\hline Well name & Stratigraphic unit & $\begin{array}{l}\text { Depth } \\
\text { interval } \\
\text { (ft bls) }\end{array}$ & $\begin{array}{l}\text { Thickness } \\
\text { (ft) }\end{array}$ & $\begin{array}{l}\text { Transmissivity } \\
\left(\mathrm{ft}{ }^{2} / \mathrm{d}\right)\end{array}$ & $\begin{array}{l}\text { Test } \\
\text { type }\end{array}$ & Data source \\
\hline EW PW-113 & $\begin{array}{l}\text { Upper Floridan aquifer } \\
\text { (Tampa Member-Ocala, Suwannee } \\
\text { Limestones-Avon Park Formation) }\end{array}$ & $183-647$ & 464 & 109,000 & A & $\begin{array}{l}\text { Nettles and Vandor, Inc. } \\
\text { (1988a) }\end{array}$ \\
\hline EW PW-134 & $\begin{array}{l}\text { Upper Floridan aquifer } \\
\text { (Tampa Member-Ocala, Suwannee } \\
\text { Limestones-Avon Park Formation) }\end{array}$ & $84-777$ & 693 & 93,600 & A & $\begin{array}{l}\text { Nettles and Vandor, Inc. } \\
\text { (1988a) }\end{array}$ \\
\hline WRAP-3D & $\begin{array}{l}\text { Upper Floridan aquifer } \\
\text { (Tampa Member-Ocala, Suwannee } \\
\text { Limestones-Avon Park Formation) }\end{array}$ & $173-1132$ & 959 & 55,100 & A & SWFWMD (1996a) \\
\hline EW PW 5 & Tampa Member-Suwanee Limestone & $59-300$ & 241 & 58,800 & A & Wolansky and Corral (1985) \\
\hline EW PW 4A & Tampa Member-Suwanee Limestone & $74-210$ & 136 & 40,100 & A & $\begin{array}{l}\text { Nettles and Vandor, Inc. } \\
\text { (1988a) }\end{array}$ \\
\hline EW PW 1 & Tampa Member-Suwanee Limestone & $173-380$ & 207 & 35,400 & A & Wolansky and Corral (1985) \\
\hline WRAP-4D & Suwannee Limestone & $180-579$ & 399 & 7,700 & A & SWFWMD (1996a) \\
\hline WRAP-3D & Suwannee Limestone & $173-500$ & 327 & 3,000 & A & SWFWMD (1996a) \\
\hline EAST LAKE WELL 19 & Suwannee-Ocala Limestones & $250-450$ & 200 & 47,200 & A & $\begin{array}{l}\text { Nettles and Vandor, Inc. } \\
\text { (1989) }\end{array}$ \\
\hline WRAP-1D & Ocala Limestone & $391-473$ & 82 & 1,000 & A & SWFWMD (1996a) \\
\hline WRAP-4D & Ocala Limestone & $437-579$ & 142 & 284 & $\mathrm{P}$ & SWFWMD (1996a) \\
\hline WRAP-3D & Ocala Limestone & $473-500$ & 27 & 248 & $\mathrm{P}$ & SWFWMD (1996a) \\
\hline WRAP-3D & Ocala Limestone & $380-398$ & 18 & 70 & $\mathrm{P}$ & SWFWMD (1996a) \\
\hline WRAP-1D & Ocala Limestone & $464-470$ & 6 & 3.8 & $\mathrm{P}$ & SWFWMD (1996a) \\
\hline WRAP-1D & Avon Park Formation & $660-691$ & 31 & 168 & $\mathrm{P}$ & SWFWMD (1996a) \\
\hline $\begin{array}{l}\text { McKAY CREEK } \\
\text { injection site }\end{array}$ & Avon Park Formation & $940-1,028$ & 88 & 896,000 & A & Hickey $(1977,1982)$ \\
\hline WRAP-1D & Avon Park (evaporite units) & $1,146-1,210$ & 64 & 6.4 & $\mathrm{P}$ & SWFWMD (1996a) \\
\hline WRAP-3D & Avon Park (evaporite units) & $1,061-1,107$ & 46 & 3.0 & $\mathrm{P}$ & SWFWMD (1996a) \\
\hline WRAP-4D & Avon Park (evaporite units) & $1,192-1,234$ & 42 & 0.71 & $\mathrm{P}$ & SWFWMD (1996a) \\
\hline
\end{tabular}

The higher transmissivity values observed in both the Tampa/Suwannee and the Avon Park producing zones are attributed to well-developed secondary porosity. Waterproducing zones are associated with fractures, cavities, or solution-enhanced bedding planes that provide potential pathways for conduit flow. These features, if interconnected, can convey large quantities of water (Knochenmus and Robinson, 1996). Units with substantial intergranular (primary) porosity but less well-developed secondary porosity, such as the Ocala semiconfining unit, have relatively lower permeability, and separate the more permeable zones.

Caliper and acoustic televiewer logs can be used to characterize lithologic properties at individual boreholes, and, by combining information from multiple boreholes, to assess the lateral continuity of specific features or hydrologic units over a larger area. Properties, such as hardness, degree of cementation, and the type and regional extent of porosity development at the formation scale, can be correlated to measured hydraulic properties, such as hydraulic conductivity and transmissivity. Voids, vugs, bedding planes, and fractures were identified in caliper and acoustic televiewer logs from selected wells in the EW well field (fig. 8). Caliper data were used to identify specific borehole characteristics that may indicate general lithologic characteristics that influence hydraulic properties. Large washout areas in caliper logs commonly correlated to poorly lithified units (fig. 10).

Consistent borehole diameter in a caliper log generally indicated a well-lithified unit. Fractures within dolomite units presented as discrete enlargements in the caliper record. Fractures were associated with the dolomitic units, and were most common within the Avon Park Formation (figs. 8, 10)

The type and extent of porosity development was evaluated for sections of the UFA using caliper and acoustic televiewer logs, which were then compared to porosity measurements determined from other investigations (figs. 5, 8). 


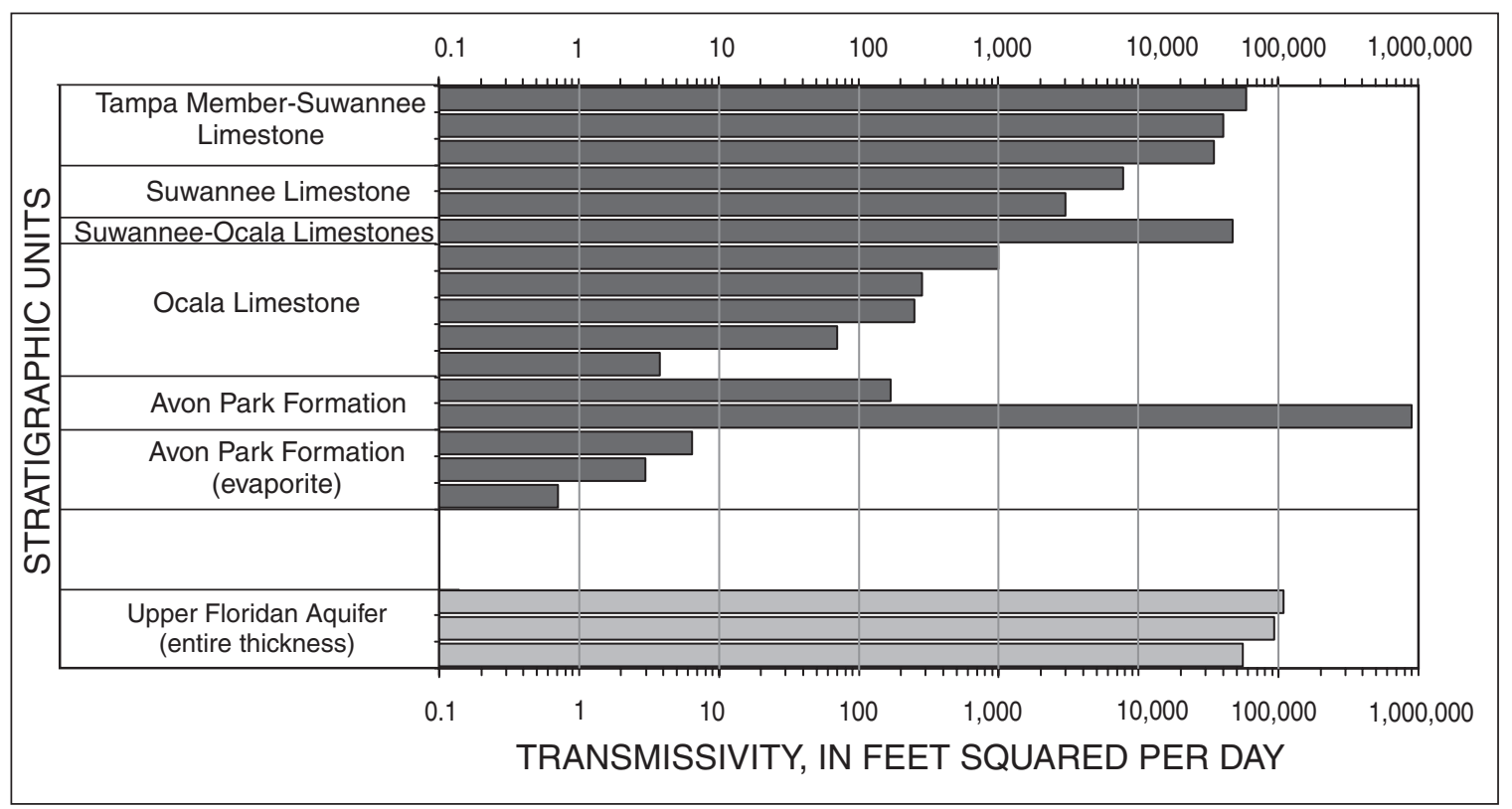

Figure 9. Transmissivity of selected depth intervals and specific stratigraphic units of the Upper Floridan aquifer within or near the Eldridge-Wilde well field. Site names and values are shown in table 2. Compiled from Southwest Florida Water Management District (1996a; 2000a).

Porosity within a particular unit may be very high, but the overall permeability of that unit may be low because the percentage of interconnected void space per total rock volume is low. For example, the Avon Park Formation has the lowest effective porosity compared to the Ocala Limestone, which has the highest effective porosity, and yet, the Avon Park Formation is nearly 3,000 times more transmissive than the Ocala Limestone. This difference indicates that hydraulic conductivity and porosity values determined from cores should be used cautiously, because they may not describe formation-scale properties. Effective porosities in the UFA measured in carbonate cores from six selected sites in west-central Florida, ranged from 2 to 49 percent (Knochenmus and Robinson, 1996; Southwest Florida Water Management District, 1996a).

Another method for delineating producing zones is to measure the specific capacity for individual wells. Specific capacity is the yield of the well per unit of drawdown in the water level, which is expressed as gallons per minute per foot of drawdown (gal/min/ft). Although specific capacity generally varies with duration of pumping, specific capacity measurements from wells with limited open-hole intervals can provide information about the productivity of specific units or features. Specific capacity can be measured repeatedly for a well. The original specific capacity is determined upon completion of a well. Subsequent specific capacity measurements can be made after a well is deepened or modified when the specific capacity of the well likely has changed. In this report, final specific capacity refers to the most recently reported specific capacity data available at the time of this report (app. A). Specific capacity data also can be used to calculate transmissivity values (Driscoll, 1986). Within the study area, calculated transmissiv- ities for the production wells at EW using the final specific capacity values reported in appendix A ranged from 10,700 to $160,400 \mathrm{ft}^{2} / \mathrm{d}$, with a median value of $46,800 \mathrm{ft}^{2} / \mathrm{d}$.

Specific capacity values from multiple wells open to similar hydrogeologic units were compared to determine the effect of structural features, specific producing zones, or stratigraphic units on hydraulic properties. For 19 wells open to the Tampa Member and Suwannee Limestone (average well depth of $277 \mathrm{ft}$ ), the specific capacity values ranged from 39 to 320 $\mathrm{gal} / \mathrm{min} / \mathrm{ft}$, with an average of $125 \mathrm{gal} / \mathrm{min} / \mathrm{ft}$ (app. A., fig. 11). Thirty-four wells open to the Tampa Member and both the Suwannee and Ocala Limestones (average depth of $372 \mathrm{ft}$ ), had specific capacity values ranging from 13 to $600 \mathrm{gal} / \mathrm{min} / \mathrm{ft}$ with an average of $121 \mathrm{gal} / \mathrm{min} / \mathrm{ft}$. The additional average well depth of $100 \mathrm{ft}$ into the Ocala Limestone did not improve the average specific capacity, which reflects the lower transmissivity of the Ocala Limestone compared to other stratigraphic units composing the UFA. Twenty-three wells open to the Avon Park Formation (average depth of $771 \mathrm{ft}$ ), had specific capacity values that ranged from 86 to $563 \mathrm{gal} / \mathrm{min} / \mathrm{ft}$, with an average of 309 $\mathrm{gal} / \mathrm{min} / \mathrm{ft}$. The increase in specific capacity resulted from these wells intersecting the highly permeable fracture zones within the Avon Park Formation (fig. 11a). The SWFWMD (1996a) documented a similar increase in specific capacity with depth in wells WRAP-1D, WRAP-3D and WRAP-4D, tapping a highly transmissive zone in the Avon Park Formation.

Within the well field, specific capacity values increase with increasing length of open hole. Specific capacity values for all 58 production wells in the EW well field range from 40 to $600 \mathrm{gal} / \mathrm{min} / \mathrm{ft}$, and average $208 \mathrm{gal} / \mathrm{min} / \mathrm{ft}$ (Black, Crow, and Eidsness, Inc., 1970; Gee and Jenson, Inc., 1981a,b, 1983; 


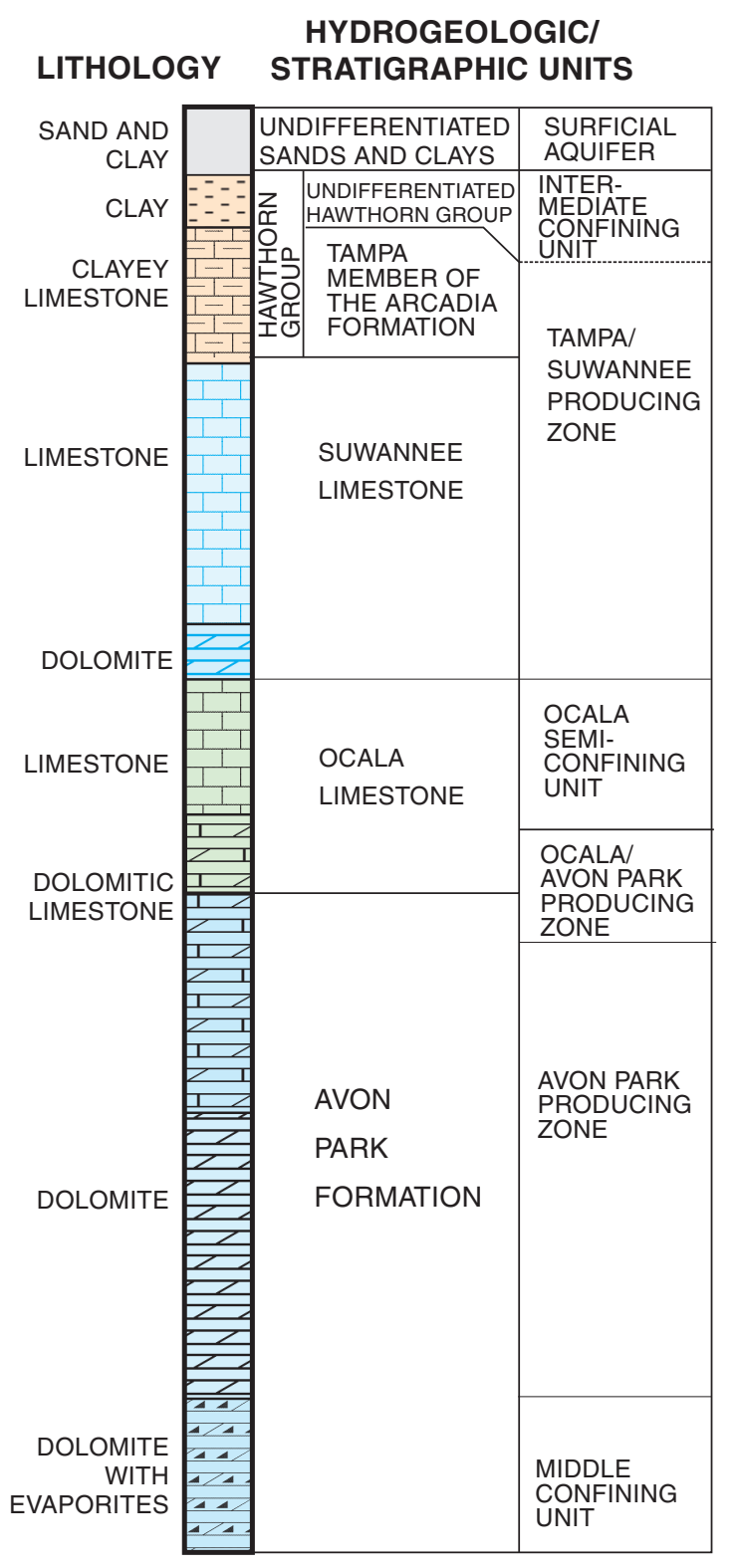

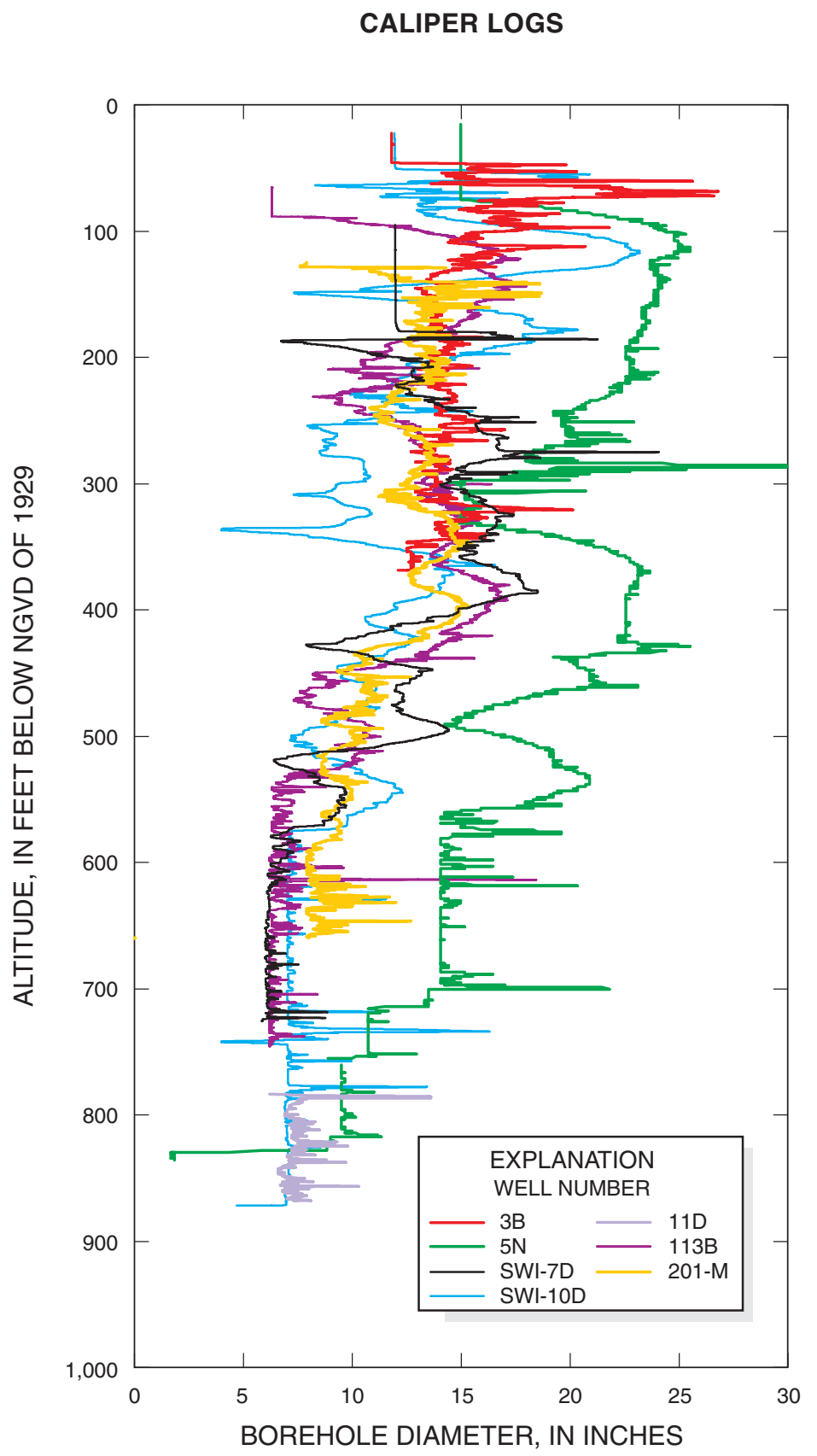

Figure 10. Hydrogeologic units, producing zones, lithology, and caliper logs collected at selected wells located within or near the Eldridge-Wilde well field. Well locations shown in fig. 2.

Nettles and Vandor, Inc., 1985) (fig. 11a). The highest specific capacity values are in the northern and eastern parts of the well field where production wells are deeper (average depth of $771 \mathrm{ft}$ ), open to multiple producing zones, and tap the Avon Park producing zone. Wells in the southwestern part of the well field have an average depth of $277 \mathrm{ft}$ and tap only the Tampa Member and the Suwannee Limestone. These shallower wells have lower specific capacity values than the deeper wells. When specific capacity data are normalized to length of open- hole interval, however, data from different wells with different lengths of open hole are more comparable. Normalized specific-capacity data show that wells in the southwestern part of the well field have some of the highest specific capacity values within the well field (fig. 11b). The Tampa Member and the Suwannee Limestone apparently have substantial producing zones, which may be related to stratigraphic characteristics, porosity, structural features, and (or) discontinuities in the geologic framework (fig. 11b) (app. A). 

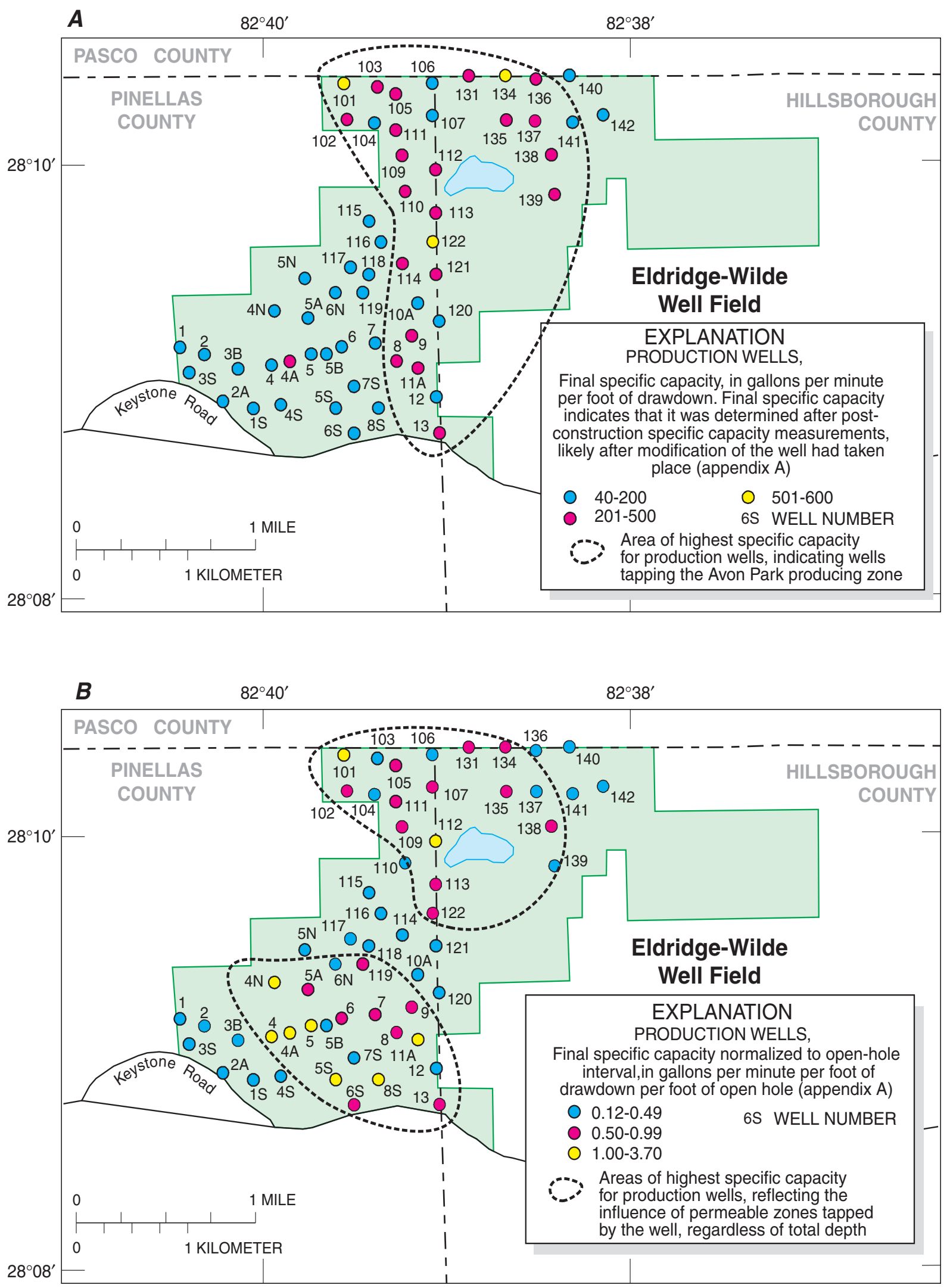

Figure 11. Specific capacity data for wells at the Eldridge-Wilde well field by (A) final specific capacity, and (B) final specific capacity normalized for length of open hole. Data are provided in appendix A; from Black, Crow, and Eidsness, Inc. (1970); Gee and Jenson, Inc. (1981a,b; 1983); Nettles and Vandor, Inc. (1985). 


\section{Effects of Aquifer Heterogeneity on Ground-Water Flow and Chloride Concentrations, West-Central Florida}

\section{Tampa/Suwannee Producing Zone}

Detailed studies at specific sites in Pinellas County have delineated at least three permeable zones and two semiconfining units within the Tampa Member and the Suwannee Limestone, indicating that some of these zones can be laterally continuous (Hickey, 1982; Knochenmus and Thompson, 1991; Knochenmus and Swenson, 1996; Broska and Barnette, 1999). Transmissivity values for the Tampa/Suwannee producing zone determined outside the well field but within west-central Florida range from 18,700 to 73,500 $\mathrm{ft}^{2} / \mathrm{d}$ (Dames and Moore, 1988; Southwest Florida Water Management District, 1996a,b, 2000a) (fig. 9). These values are similar to values for the entire UFA and are some of the highest values determined for all stratigraphic units within the UFA. Normalized specific capacity data also indicate that the Tampa/Suwannee producing zone is an important producing zone within the EW well field. Within the well field, transmissivity values for the Tampa/ Suwannee producing zone range from 35,400 to $58,800 \mathrm{ft}^{2} / \mathrm{d}$ (table 2) (Wolansky and Corral, 1985; Nettles and Vandor, Inc., 1988a). Wells 4, 4A, and 5, in the southwestern part of the well field, are open to this unit and all have normalized specific capacity values of 1 or greater (fig. 11b).

Porosity of the Tampa/Suwannee producing zone has been characterized as fractured and vuggy with cavities (Knochenmus and Robinson, 1996). Although porosity varies markedly within the Suwannee Limestone, the porosity range is similar to that of the Tampa Member, ranging from 21 to 42 percent (Knochenmus and Robinson, 1996). Primary pores in the grainstones and packstones in the Tampa Member are responsible for more than 75 percent of the rock porosity, which has been estimated to be 29 percent (Knochenmus and Robinson, 1996). Depending on clay content and borehole stability, the Tampa Member may be cased. Where the borehole is left open for a production well, caliper logs indicate that the unit is often washed out during drilling, likely a result of poor induration and high intergranular porosity (fig. 10). Boreholes open to the Tampa/Suwannee producing zone exhibit a wide range in caliper diameter between individual sites, indicating that the unit is highly variable in hardness and porosity (fig. 10). Enlarged borehole conditions typically extend 5 in. beyond the original borehole diameter (fig. 10). Because of the extent of cavity development, many of the observed fractures may be the result of cavity collapse and failure. Drilling techniques can affect caliper logs, as Safko and Hickey (1992) and Duerr (1995) suggested that borehole characteristics seen in caliper logs can be a result of drilling activity. Although drilling techniques do affect borehole characteristics, the resulting caliper logs reflect variations in lithologic properties.

Regionally, the Suwannee Limestone is well lithified and maintains a more consistent borehole diameter near the base, where dolomite commonly is present near the contact with the Ocala Limestone (fig. 10). Porosity within the Suwannee Limestone does not appear to correspond to vertical stratigraphic trends within the unit, indicating that secondary porosity is important (Hammes, 1992). The karst features that are charac- teristic of the Suwannee Limestone are responsible for much of the secondary porosity (Hammes, 1992). Ground-water flow and subsequent dissolution of limestone along these pathways maintain and enlarge these features, resulting in the productive zones observed within the Tampa Member and the Suwannee Limestone.

\section{Ocala Semiconfining Unit}

The Ocala Limestone is a fine-grained, pure limestone that is poorly indurated in parts of the unit, and contains abundant foraminifera. Because the Ocala Limestone likely was not subaerially exposed to any degree, the unit has maintained much of the original depositional properties and has less welldeveloped secondary porosity than the Suwannee Limestone (Loizeaux, 1995). Porosity in the Ocala Limestone ranges from 12 to 41 percent with an average of 32 percent (Loizeaux, 1995). Effective porosity measurements compiled by Knochenmus and Robinson (1996) for porosities classified as intergranular to moldic are slightly higher, ranging from 27 to 49 percent. Porosity can be associated with depositional facies, so if specific depositional facies are laterally extensive, they may have an effect on areal hydrologic properties. A zone of higher vertical conductivity within the Ocala Limestone has been mapped along a northeastern-southwestern trend through Pasco, Pinellas, and Hillsborough Counties. The higher vertical conductivity corresponds to a coarse-grained facies that is dominated by interparticle and macro porosity (Loizeaux, 1995).

Transmissivity in discrete depth intervals within the Ocala semiconfining unit at three wells surrounding the EW well field ranges from 3.8 to nearly $1,000 \mathrm{ft}^{2} / \mathrm{d}$, averaging $320 \mathrm{ft}^{2} / \mathrm{d}$ (table 2 , fig. 9). These data indicate the variability as well as the relatively low permeability of the Ocala Limestone compared to other stratigraphic units within the UFA. The higher transmissivity values usually correspond to the lower Ocala Limestone, which forms part of the Ocala/Avon Park producing zone.

Caliper logs for nearly all selected wells showed enlarged borehole conditions for the Ocala Limestone owing to the combination of poor induration and washouts created during well construction (fig. 10). The consistent appearance of the enlarged borehole conditions in all caliper logs indicate that this is characteristic of the stratigraphic unit and could be indicative of a regional trend. Enlarged boreholes in this zone make it difficult to collect borehole geophysical data, resulting in the lack of hydrogeologic information about this part of the Ocala Limestone.

\section{Ocala/Avon Park Producing Zone}

An increase in transmissivity within the lower Ocala Limestone and the Upper Avon Park Formation results in the Ocala/Avon Park producing zone. The increase in transmissivity is due to a combination of fractures and secondary porosity that were observed in caliper and acoustic televiewer logs in wells within the EW well field (figs. 8, 10). The Ocala 
Limestone is characterized by intact units with vuggy porosity interspersed with large sections exhibiting enlarged borehole conditions similar to the Ocala semiconfining unit (at wells $5 \mathrm{~N}$, $113 \mathrm{~B}$, and 201M) (figs. 8, 10). Although it is nearly a pure limestone, the Ocala Limestone contains some chert and dolomitized sections near the base, which can be extremely hard. Fractures present in the lower parts of this unit are associated with dolomite. Large voids observed in acoustic televiewer data acquired from wells 113-B and 201-M at a depth $450 \mathrm{ft}$ below NGVD of 1929 indicate the porosity is dominated by enlarged horizontal bedding planes. Acoustic televiewer data from deeper wells (202-M and 5N) show the frequency of fractures increasing with depth (fig. 8). This apparent enhanced secondary porosity is consistent with borehole video log data described by Knochenmus and Robinson (1996). Although these zones may have been created by drilling activity and (or) associated washout zones, the appearance of fractures and (or) large voids corresponds to higher transmissivity and specific capacity observed at the contact between the lower Ocala Limestone and the upper Avon Park Formation (table 2) (Southwest Florida Water Management District, 1996a). The combination of large solution-formed caverns and fractures likely increases the secondary porosity within the lower Ocala Limestone and the Upper Avon Park Formation (Hickey, 1982; Dames and Moore, 1988; Loizeaux, 1995; Knochenmus and Robinson, 1996; Southwest Florida Water Management District 1996a).

\section{Avon Park Producing Zone}

The Avon Park producing zone is the most important water-producing zone in the UFA in Florida. Fractured dolomite supplies the majority of water to wells open to the entire UFA (Ryder and Mills, 1978; Ryder, 1985; CH2M Hill, Inc., 1990a,b; HydroGeologic, Inc., 1992). Porosity derived from cores ranges from 2 to 25 percent, but core samples from this unit disproportionately represent the least permeable zones. Fracture porosity and formation-scale porosity cannot be measured at the core scale, therefore, hydraulic analyses of core materials are not an effective way to measure the overall permeability of this unit (Knochenmus and Robinson, 1996). The regional transmissivity values for the Avon Park Formation derived from aquifer tests at six sites in west-central Florida range from 98,000 to 1,200,000 $\mathrm{ft}^{2} / \mathrm{d}$ (Dames and Moore, 1988). At McKay Creek, southwest of the study area, an 88-ftlong section of the Avon Park producing zone had a transmissivity of $896,000 \mathrm{ft}^{2} / \mathrm{d}$ (Hickey, 1982). Southeast of the well field at well WRAP-1D, a 30-ft-long section of the Avon Park producing zone had a transmissivity value of $168 \mathrm{ft}^{2} / \mathrm{d}$ (Southwest Florida Water Management District, 2000a).

The Avon Park Formation is approximately $300 \mathrm{ft}$ thick, and is present at an elevation ranging from 475 to $775 \mathrm{ft}$ below NGVD of 1929 (fig. 4). Limestone and dolomitic limestone are present primarily in the upper part of the formation as well as a fine-grained recrystallized packstone (fig. 10). Both the caliper and the acoustic televiewer logs show a marked change at approximately 525-550 ft below NGVD of 1929, corresponding to the increased presence of dolomite (figs. 8, 10). At this depth, borehole diameters are more constant than those observed at shallower depths, and washout sections are uncommon. The distinct change in rock fabric and porosity type marks the presence of continuous dolomite, which is hard, brown, sucrosic in texture, and highly fractured. From approximately 550 to $725 \mathrm{ft}$ below NGVD of 1929, the acoustic televiewer logs show that porosity type is dominated by fractures that do not appear to be substantially enlarged by dissolution. The fractures range from near horizontal to more than 85 degrees from horizontal. Multiple fractures are present, cutting across one another and enlarging the borehole. The observed enlargements associated with fractures and their intersections may be the result of dissolution or drilling activity (Safko and Hickey, 1992).

Specific capacity values generally are greater than 200 $\mathrm{gal} / \mathrm{min} / \mathrm{ft}$ when wells intercept the highly transmissive fractured Avon Park producing zone (Southwest Florida Water Management District, 1996a) (fig. 11). The average original well depth of the 57 wells at the EW well field was $355 \mathrm{ft}$. In the 1980s, 21 wells at the EW well field were deepened to penetrate the Avon Park Formation. The original specific capacities of these wells ranged from 13 to $231 \mathrm{gal} / \mathrm{min} / \mathrm{ft}$ with an average of $85 \mathrm{gal} / \mathrm{min} / \mathrm{ft}$ of drawdown. After deepening the wells, specific capacities ranged from 121 to $563 \mathrm{gal} / \mathrm{min} / \mathrm{ft}$, with an average of $319 \mathrm{gal} / \mathrm{min} / \mathrm{ft}$ of drawdown. The maximum increase in specific capacity was $400 \mathrm{gal} / \mathrm{min} / \mathrm{ft}$ with an average increase of 230 $\mathrm{gal} / \mathrm{min} / \mathrm{ft}$. By deepening the wells, the average specific capacity increased by more than 250 percent. Transmissivity calculated for EW production wells that were deepened into the Avon Park Formation had a median value of $90,600 \mathrm{ft}^{2} / \mathrm{d}$.

No apparent pattern or lateral continuity of specific fractures was observed in the Avon Park producing zone, and the lateral continuity of specific fractures between two or more boreholes was not determined. Although the dominant orientation of the fractures is not known, the fractured unit is a consistent feature throughout Pinellas County (Hickey, 1982). A laterally continuous unit with substantial secondary porosity likely has extensive influence on ground-water movement throughout the region. If the fractures within this zone have a dominant orientation, ground-water movement would likely reflect this influence.

\section{Middle Confining Unit}

The transmissivity of the MCU was determined to range from 0.71 to $6.4 \mathrm{ft}^{2} / \mathrm{d}$ at WRAP wells $1 \mathrm{D}, 3 \mathrm{D}$, and 4D, surrounding the EW well field (Southwest Florida Water Management District, 1996a). No fractures were detected in the televiewer data from well SWI-10D in the lower part of the Avon Park Formation where evaporites are present. Drilling reports for well SWI-10D confirmed this observation and indicated that the characteristic Avon Park fractured zone does not extend much deeper than $800 \mathrm{ft}$ below NGVD of 1929 (Nettles and Associates, Inc., 1991c). 


\section{Effects of Aquifer Heterogeneity on Ground-Water Flow and Chloride Concentrations, West-Central Florida}

\section{Ground-Water Development and Flow Patterns}

The occurrence and quality of ground water within the study area changed as ground-water resources were developed within the EW well field. The spatial distribution and depth of production wells has expanded since the first 19 wells were drilled in the 1950s in the southwestern part of the well field (Black, Crow, and Eidsness, Inc., 1970) (app. A, fig. 12a). The wells were installed in a geometric orientation of three groups; two east-west oriented groups located in the northeastern and the southwestern parts of the well field and a group of wells oriented north to south linking the two east-west trending groups. Pumping zones also vary in a northeast-southwest pattern - the southwestern group of wells generally tap only the shallower Tampa/Suwannee producing zone; the remaining wells generally have large open-hole intervals tapping the entire thickness of the UFA.

Nineteen wells, drilled during the 1950s and located in the southwestern part of the present well-field property, penetrate the Tampa/Suwannee producing zone. Initially, the average well was $277 \mathrm{ft}$ deep with $87 \mathrm{ft}$ of casing and $193 \mathrm{ft}$ of open hole (app. A). The shallowest well was $140 \mathrm{ft}$ and the deepest was $346 \mathrm{ft}$. From 1960 to 1969, 34 additional wells were drilled. These new wells were constructed primarily to the north and east of the original wells and penetrated the Tampa/Suwannee producing zone and the Ocala semiconfining unit (fig. 12). The average depth was $372 \mathrm{ft}$, cased to $79 \mathrm{ft}$, with $289 \mathrm{ft}$ of open hole. The shallowest well was $210 \mathrm{ft}$ and the deepest well was $560 \mathrm{ft}$.

In the 1970s, five additional wells were drilledthe southwestern and three in the central parts of the well field (fig. 12). Wells drilled in the southwestern part of the well field (wells 2A and 3B) were 450 and $410 \mathrm{ft}$ deep, respectively, and were slightly deeper than those drilled in the 1950s. In the central part of the well field, three new wells were drilled to 291, 770, and $809 \mathrm{ft}$ below land surface. Open holes ranged from 168 to $731 \mathrm{ft}$, with the deeper wells penetrating the Avon Park producing zone.

From 1981 to 1986, 21 preexisting wells at the EW well field were deepened to an average depth of $769 \mathrm{ft}$ (minimum depth of $647 \mathrm{ft}$ and maximum depth of $863 \mathrm{ft}$ ) to penetrate the Avon Park producing zone (fig. 12a). The deepened wells were located primarily in the northern and eastern sections of the well field. In 1986, more than 40 percent of the 54 production wells active at the EW well field accessed the Avon Park producing zone. After the wells were deepened, nearly half of the EW well field water (43 percent) was produced from wells with more than $500 \mathrm{ft}$ of open hole tapping the highly transmissive $600-750 \mathrm{ft}$ zone.

\section{Ground-Water Withdrawals and Water Levels}

Annual daily average pumpage calculated for the well field from 1956 to 2000 indicates that the lowest production levels occurred in the 1950s when the well field was first put into use (fig. 13). From 1960 to 1970, withdrawals increased from 10 to $25 \mathrm{Mgal} / \mathrm{d}$ as the number and spatial extent of wells expanded into the northern part of the well field. Ground-water withdrawals peaked near $35 \mathrm{Mgal} / \mathrm{d}$ in June 1973. During this time, withdrawals were limited to the upper part of the UFA including the Tampa Member and the Suwannee and Ocala Limestones (fig. 13).

Although total pumpage peaked in 1973, annual daily average pumpage exceeded $25 \mathrm{Mgal} / \mathrm{d}$ for much of the 1980s (fig. 13). Although withdrawals fluctuated from 1975 through 1990, annual daily average pumpage remained above $25 \mathrm{Mgal} / \mathrm{d}$ from 1984 until 1991. Lower withdrawals (below $25 \mathrm{Mgal} / \mathrm{d}$ ) occurre in 1981-1983, in 1993, and in 1995-1999, whereas high withdrawals (above $25 \mathrm{Mgal} / \mathrm{d}$ ) occurred in 1984-1986, and 1988-1990. Drought conditions during 2000 resulted in increased pumpage. At full capacity in the late 1980 s and early 1990s, 58 wells were in operation. In 2002, 36 wells remained operational.

Changes in ground-water flow patterns are the direct result of changing water levels caused by ground-water development. The configuration of the potentiometric surface in the EW well field is influenced by the location of pumping wells, their pumping rates at the time of measurement, and the spatial variation in hydraulic properties of the aquifer and recharge conditions. The mapped potentiometric surface of the UFA shows water-level contours for predevelopment and May 2000 (fig. 14). During predevelopment conditions, contours in the vicinity of the EW well field generally were parallel to the west coast of Florida (Bush and Johnston, 1988) and ground-water flow was from the east to west toward the Gulf of Mexico. In the vicinity of the EW well field, water levels declined 10 to $20 \mathrm{ft}$ from predevelopment levels (Stewart and others, 1971). Potentiometric-surface maps from the 1970's and 1980's show a potentiometric low centered on the EW well field (fig. 15).

Potentiometric-surface maps of the EW well field were constructed for May 1972, and for May and September from 1976 through 1982 (Craig Hutchinson, U.S. Geological Survey, written commun., 1972; Hutchinson and Mills, 1977; Wolansky and others, 1978a; Johnston and others, 1980; Yobbi and others, 1980b; Barr, 1982). Representative maps for this period are shown in figure 15. During the period from 1972 to 1982, a persistent cone of depression was oriented northeast-southwest within the EW well field. To estimate the amount of groundwater decline associated with ground-water withdrawals, an altitude contour representative of the regional UFA potentiometric surface within the EW well field area unaffected by pumping was selected for each map (shown as red contours in figure 15). Declines in the potentiometric surface were estimated by calculating the difference between the representative regional potentiometric surface and the observed minimum altitude of the UFA (shown as bold blue contours in figure 15). Although the shape of the depression changed over time, waterlevel declines ranging from 6 to $18 \mathrm{ft}$ below the representative regional ground-water level persisted (fig. 15). The change in the shape of the depression appears to be influenced by changes in withdrawal locations. 

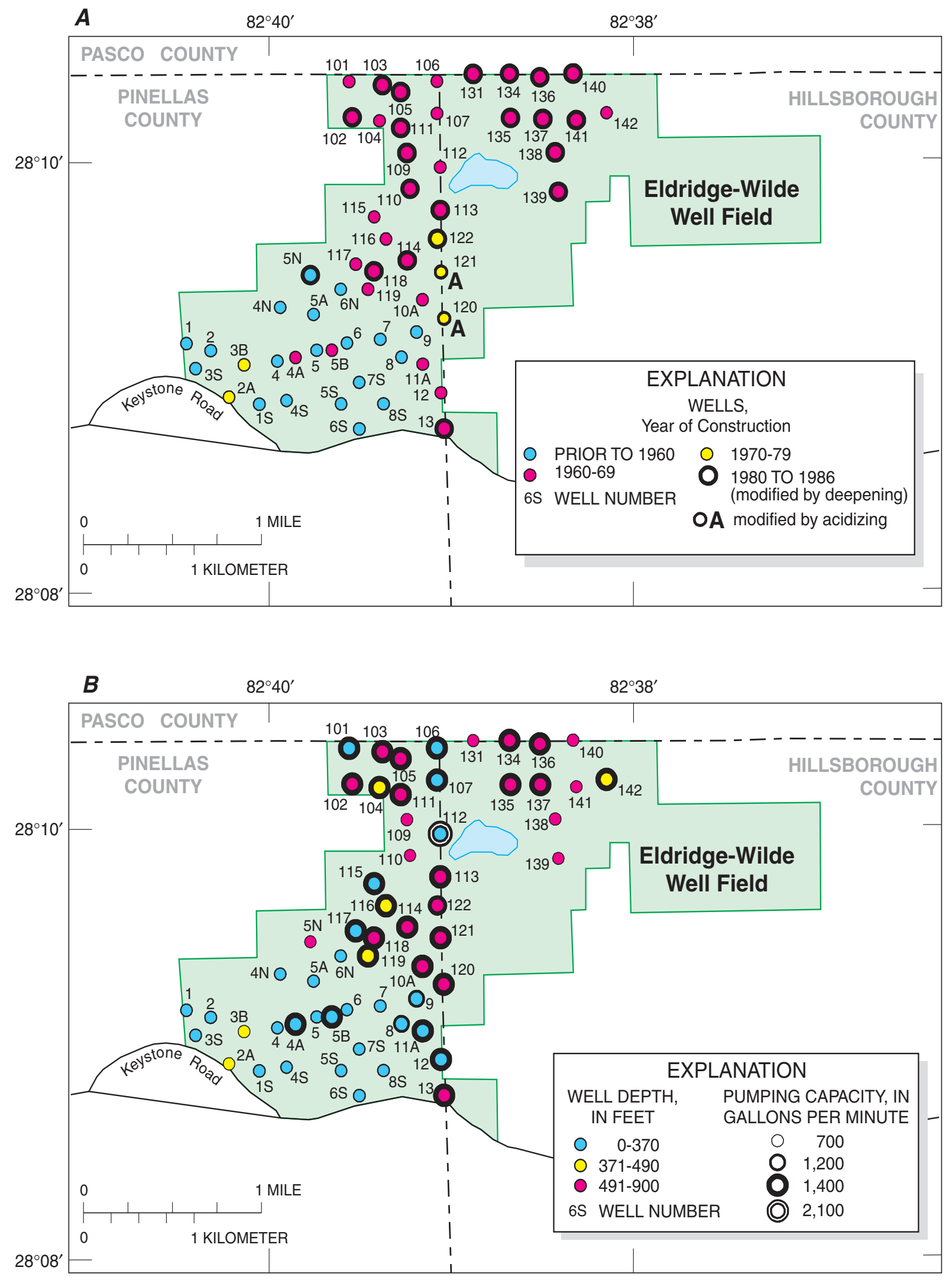

Figure 12. Selected wells at the Eldridge-Wilde well field showing (A) dates of well construction and wells that were deepened from original depth or acidized to increase production, and (B) final well depths and pumping capacity (2002). Data are in appendix A. 


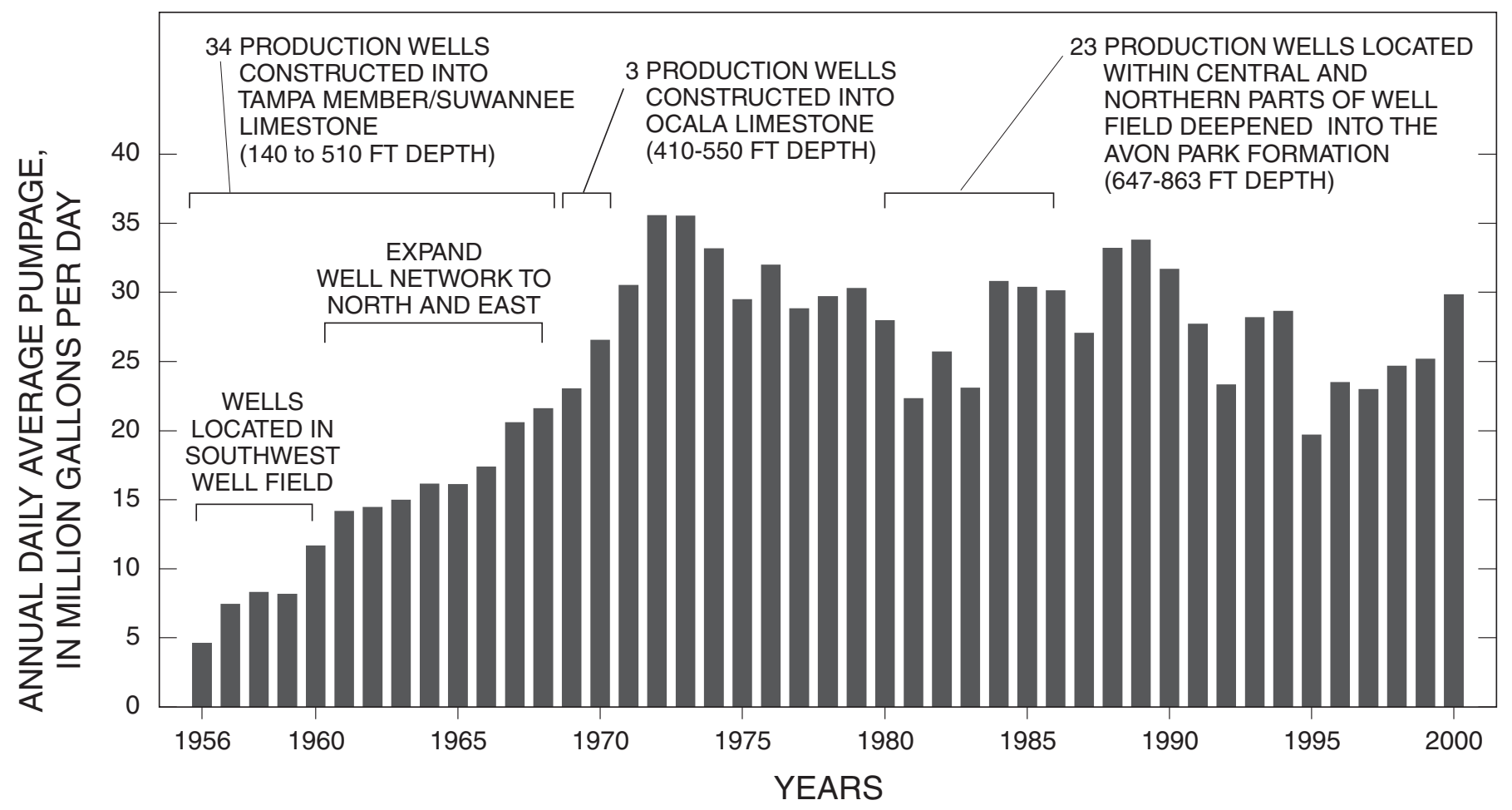

Figure 13. Ground-water withdrawals from the Eldridge-Wilde well field, 1956-2000. Data provided by Tampa Bay Water.

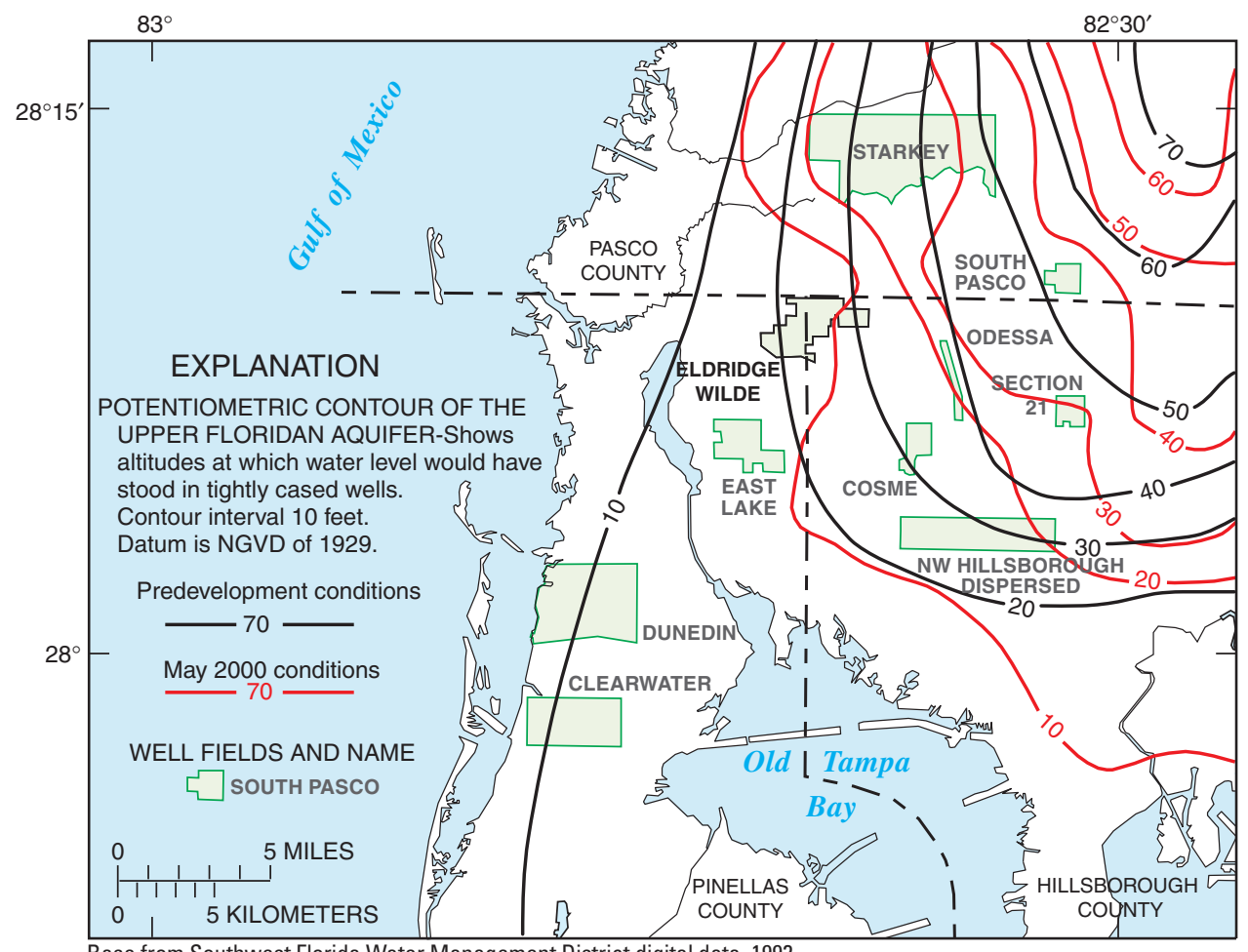

Base from Southwest Florida Water Management District digital data, 1992 Universal Transverse Mercator projection, Zone 17

Figure 14. Regional potentiometric surface of the Upper Floridan aquifer for predevelopment conditions and May 2000 hydrologic conditions. Modified from Bush and Johnston (1988) and Duerr (2001). 
Estimated potentiometric map

prior to development (after Johnston and others, 1980)

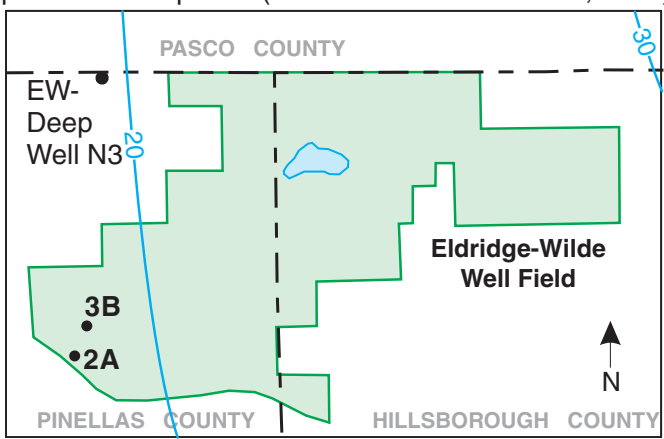

May $1976 \quad$ Estimated decline 10 feet
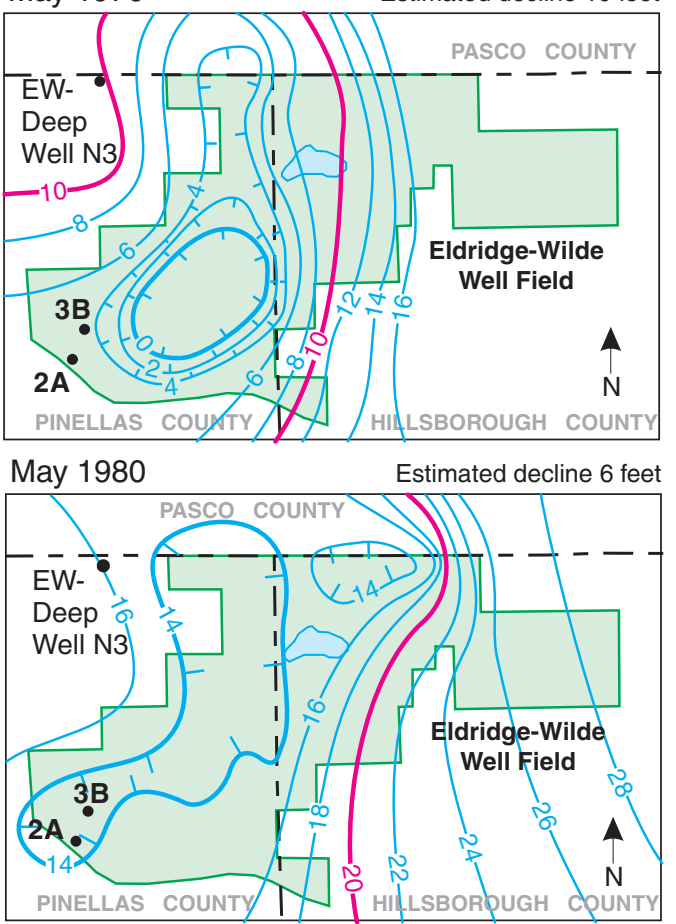

Base from Southwest Florida Water Management District digital data, 1992 Universal Transverse Mercator projection, Zone 17

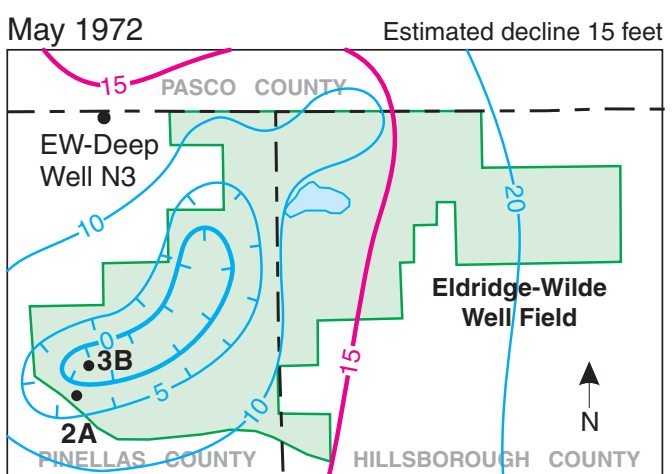

May $1978 \quad$ Estimated decline 12 feet
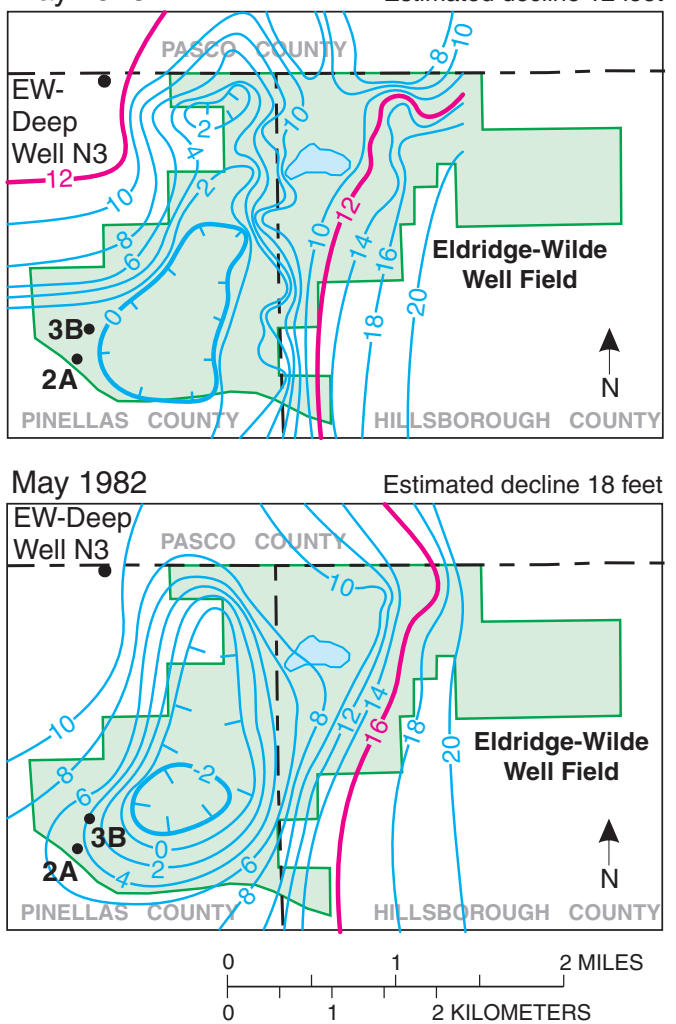

\section{EXPLANATION}

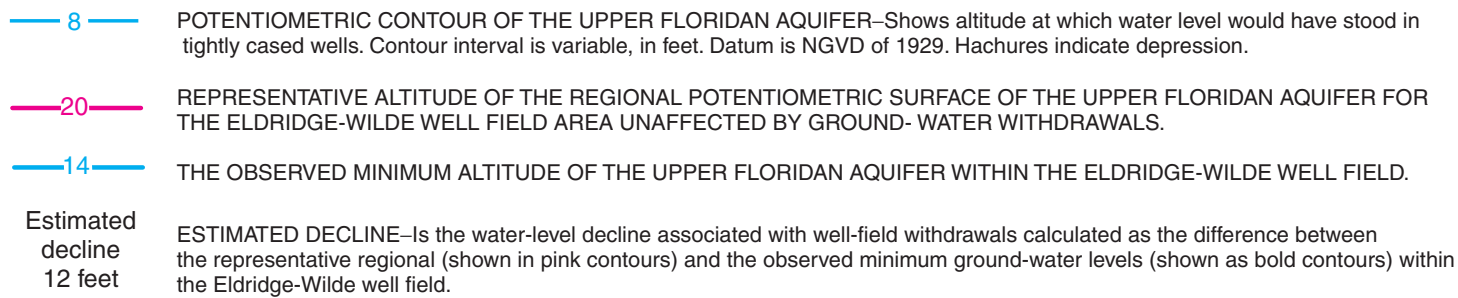

- 2A Well location AND NAme

Figure 15. Semi-annual potentiometric-surface maps and estimated decline of the Upper Floridan aquifer at the EldridgeWilde well field from predevelopment of ground water to 1982. Modified from Hutchinson, U.S. Geological Survey, written commun. (1972); Hutchinson and Mills (1977); Wolansky and others (1978a); Johnston and others (1980); Yobbi and others (1980b); Barr (1982). 
From 1972 through 1976, the cone of depression was centered over the southwestern part of the well field, coincident with locations of production wells (Geraghty \& Miller, Inc.,1976a,b) (fig 15). From 1977 to 1980, as ground-water withdrawals expanded to the north, the cone of depression extended into the northeastern part of the well field. By 1982, the shape of the cone of depression was an enlarged, elongated, northeast-southwest trending trough across the expanded well field. Water-level declines and their areal extent vary seasonally. Water levels for May (the dry season) are consistently lower over a larger area than those for September. In May 1972, 1976, and 1978, ground-water levels in the southwestern part of the well field were below NGVD of 1929. In May 1982, the maximum decline was $2 \mathrm{ft}$ below NGVD of 1929 and groundwater levels within a large part the well field were $18 \mathrm{ft}$ below representative regional levels.

Although the potentiometric surface of the UFA in the EW well field has not been mapped since 1982, continuous water levels monitored at well EW Deep Well N3 provide a benchmark for water-level changes at the northern boundary of the well field (fig. 15). Because this well is located away from the center of the well field, water levels at this site provide a conservative estimate of water-level changes related to pumping. Water levels in well N3 declined from 1980 to 1990 (fig. 16). From 1990 through 2000, the declining trend was reduced, but larger seasonal changes in maximum and minimum water levels occurred from 1998-2000 (fig. 16). Monthly average water

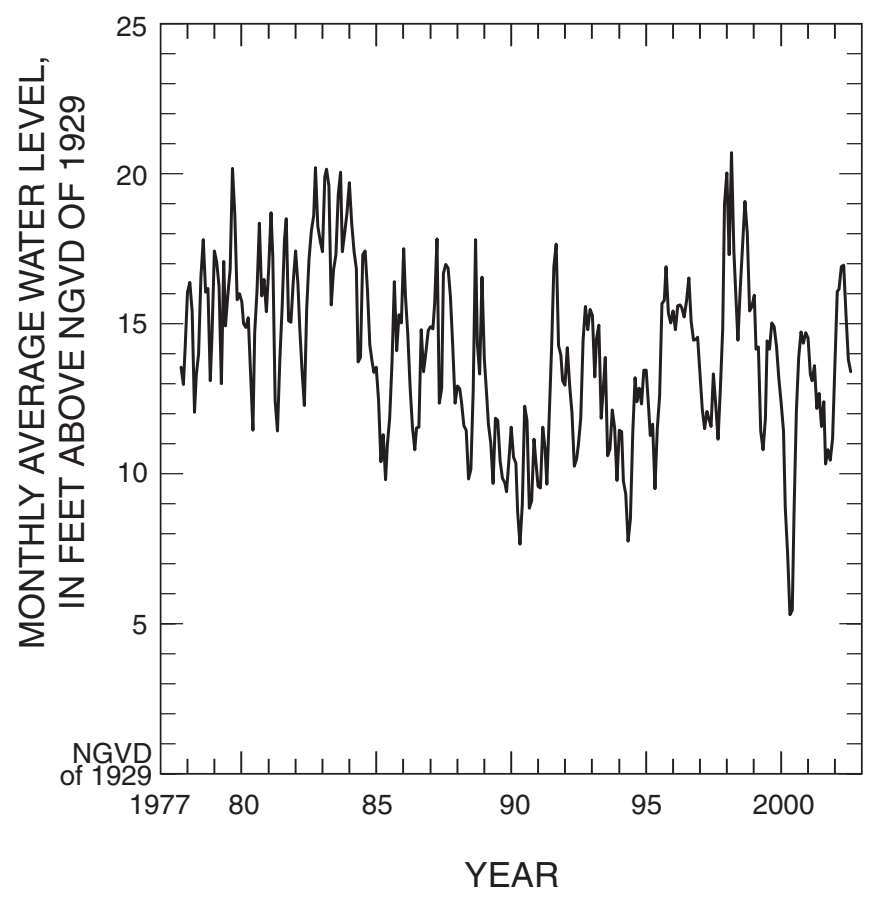

Figure 16. Water levels at Eldridge-Wilde Deep Well N3, 1977-2002. Well location shown in figs. 2 and 15. levels in well N3 from 1985 to 2001 were frequently lower than the maximum declines observed in 1982, the last year that potentiometric-surface maps were produced for the well field (fig. 16). Localized lowering of water levels in the vicinity of the EW well field also is shown on the regional potentiometricsurface map of the UFA for May 2000 (Duerr, 2001) (fig. 14). Minimum water levels for the period of record were recorded at EW Deep Well N3 in 2000; water levels were probably even lower within the cone of depression in the central part of the well field during 2000 .

\section{Evidence of Ground-Water Flow Patterns from Borehole Logs}

The location, extent, and type of permeable intervals present within the UFA at and near the EW well field affect ground-water levels, ground-water flow, and water quality. Permeable intervals, created by zones of increased transmissivities, fractures, and collapse features, provide a complex network of localized pathways for ground-water movement (fig. 17a-d). Zones of high hydraulic conductivities create preferred pathways along which ground water can move. Contrasts in geologic materials, such as abrupt changes in lithology, can produce zones along which ground water moves preferentially. Stratigraphic heterogeneity, occurring when enhanced secondary porosity develops along horizontal beds that produce enlarged bedding planes, results in preferential ground-water flow predominantly in a lateral direction (fig. 17a).

Structural heterogeneity attributed to fractures commonly produces preferential flow paths in a more vertical direction (fig. 17b). In combination, vertical and horizontal features can result in permeable intervals and flow path networks that can be laterally and vertically extensive (fig. 17c). Enhanced secondary porosity due to dissolution along these features can further expedite preferential ground-water movement (fig. 17c).

Pumping from a heterogeneous flow network can result in complex flow patterns (fig. 17d). As pumping lowers heads in the UFA, specific zones respond more readily than others. Head differences between the different permeable zones control the timing and direction of ground-water flow along various permeable zones. Depending on the head gradients and ground-water withdrawals, existing conduits can create pathways along which ground-water movement is intermittent. Withdrawals from multiple boreholes tapping multiple permeable zones can result in complex hydraulic head differences within and between wells, and can induce vertical internal borehole flow. In these instances, production wells function as large vertical conduits interconnecting permeable zones and other wells, and in some cases, degrading potable ground water with water from nonpotable zones (fig. 17d) (Spechler, 1994; Metz and Brendle, 1996).

The locations of flow zones, which are indicative of permeable intervals, were determined using flow logs and fluid conductance logs in the boreholes at wells $2 \mathrm{~A}, 3 \mathrm{~B}, 5 \mathrm{~N}$, and 201-M (figs. 18-21, respectively). In well 2A, two permeable intervals 


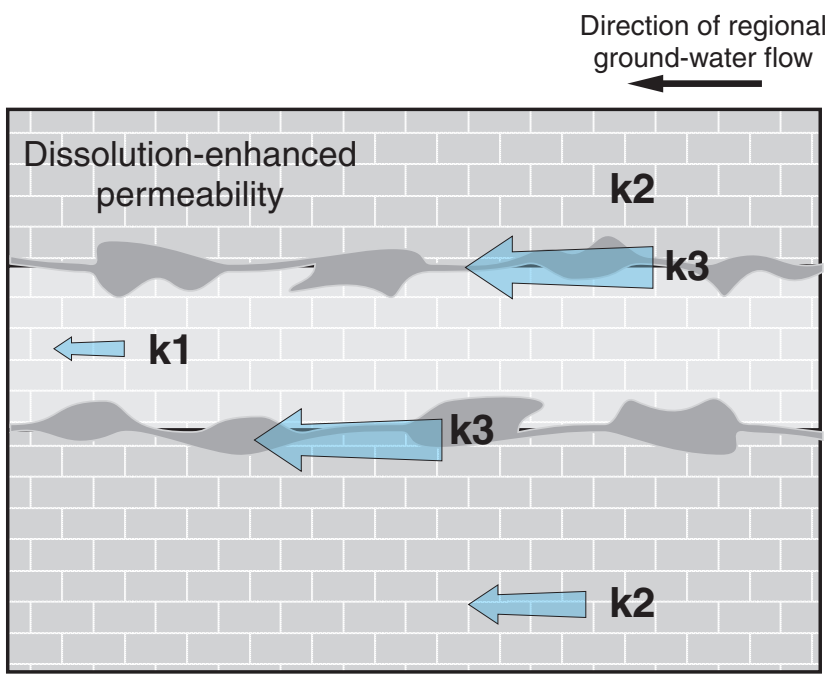

A) Stratigraphic heterogeneity

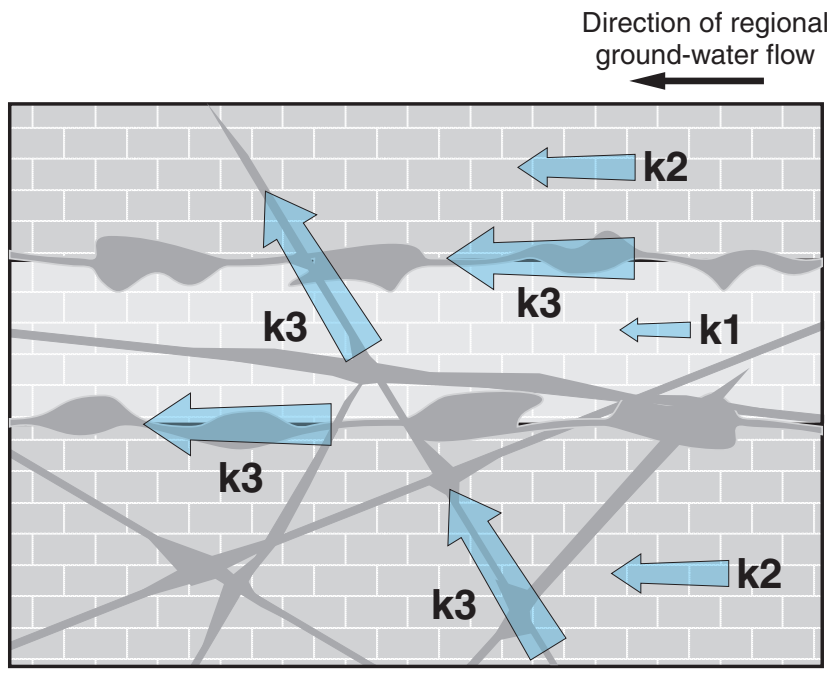

C) Stratigraphic and structural heterogeneity

\section{EXPLANATION}

k1 RELATIVE HYDRAULIC CONDUCTIVITY-k1<k2<k3

DIRECTION OF GROUND-WATER FLOW-Arrow size

indicates relative flow velocity, larger arrows = greater velocity.

Figure 17. Conceptual illustration of types of aquifer heterogeneity and ground-water flow: (A) Stratigraphic, (B) Structural, (C) Stratigraphic and structural, (D) Stratigraphic and structural with ground-water withdrawals.

are present within the Tampa/Suwannee producing zone at depths of 140 and $290 \mathrm{ft}$ below top of casing (fig.18). Under ambient conditions (shown in blue on logs), negligible flow was measured in the borehole. The ambient specific conductance logs indicated that water present from 113 to $150 \mathrm{ft}$ below the top of casing, within the upper flow zone, was fresher than water from deeper in the well. Specific conductance increased at depths of about 150,200, and $250 \mathrm{ft}$ below top of casing. At pumping rates of 35 and $53 \mathrm{gal} / \mathrm{min}(53 \mathrm{gal} / \mathrm{min}$ not shown on
Direction of regional ground-water flow

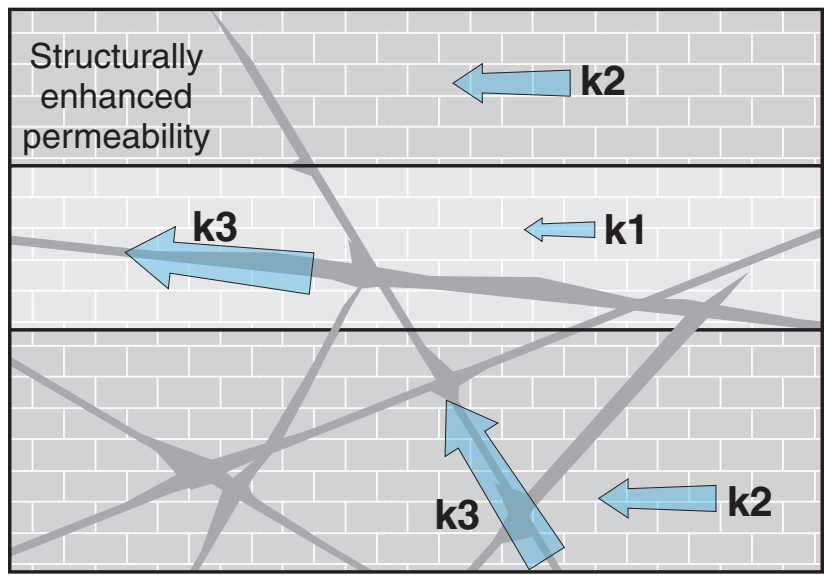

B) Structural heterogeneity

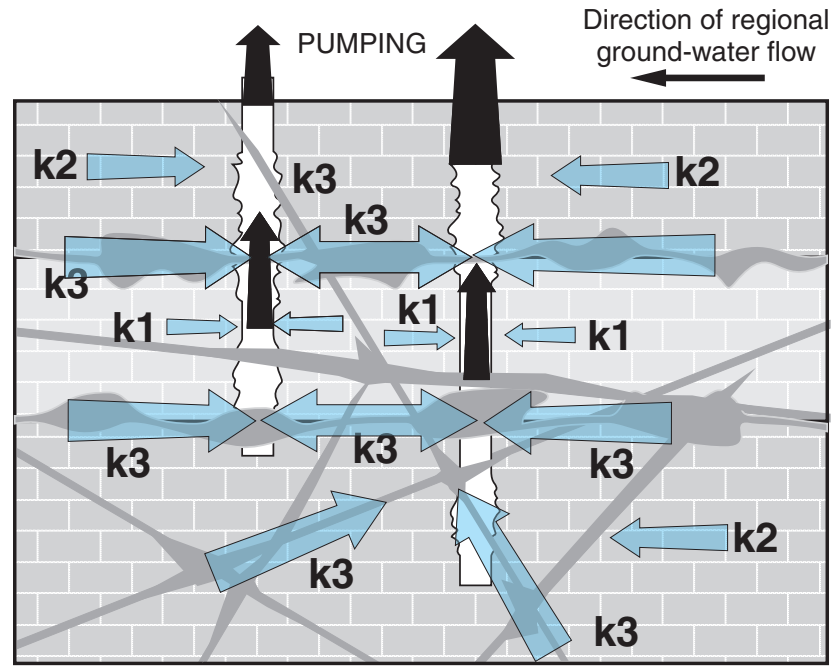

D) Stratigraphic and structural heterogeneity with ground-water withdrawals fig. 18), increases in borehole flow were observed at two main depths: 115-140 and 290-300 ft below top of casing. Specific conductance logs indicate that the lowermost permeable zone (about $290 \mathrm{ft}$ below top of casing), associated with the enlarged feature on the caliper log, contributes water that increases the specific conductance within the well. The flow measurements and specific-conductance logs indicate that the zone from 290 to $300 \mathrm{ft}$ below top of casing contributed the greatest amount of flow (fig. 18). Under pumping conditions, specific conductance 


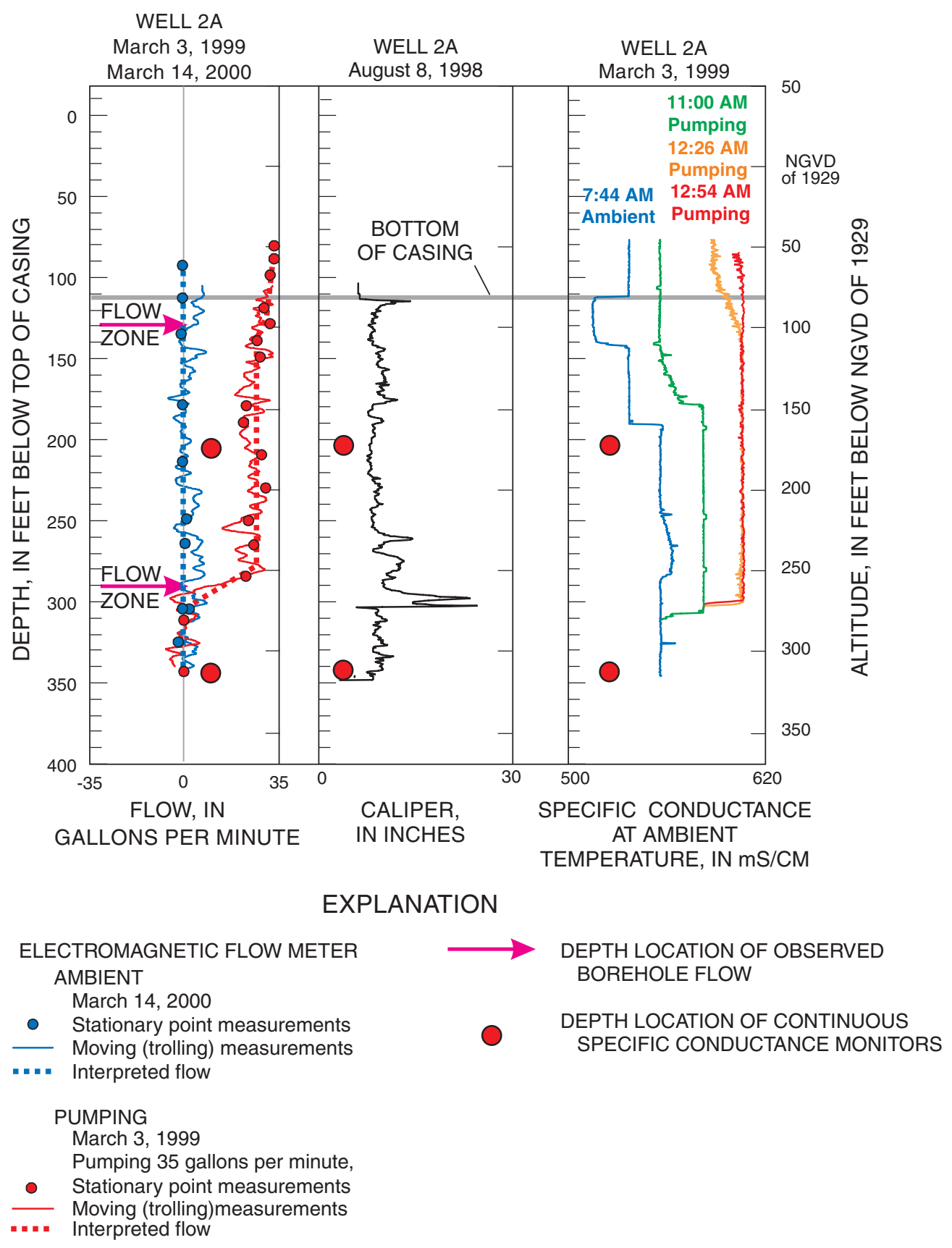

Figure 18. Flow, caliper, and fluid conductance logs at Eldridge-Wilde well 2A. Location of well shown in fig. 2.

within the entire borehole increased as water from the inflow zone at $290 \mathrm{ft}$ below top of casing dominated the composition of water. Both observed flow zones (at the bottom of the borehole and below the casing) are associated with borehole enlargements that are possibly related to bedding structures and cavernous porosity in the Tampa Member and the Suwannee Limestone.

The water level was observed to be rising during logging in well 2A, even though the well was pumping. The water level rose a total of $1.1 \mathrm{ft}$, indicating that well-field operations likely were influencing the response of well $2 \mathrm{~A}$ during the pumping flow log. Depending on well-field operations, the water from the lowermost permeable zone can dominate the composition of water in the borehole.

Although well 3B is located close to well 2A, the flow properties along the two boreholes differ substantially. The ambient flow log collected at well 3B using the electromagnetic (EM) flow meter on March 5, 1999, indicated very minor flow along the length of the borehole (fig. 19). The ambient specific conductance log indicated that specific conductance gradually increased with depth, the freshest water occurring at the base of the casing. Under pumping conditions of $37 \mathrm{gal} / \mathrm{min}$, the flow 
WELL 3B

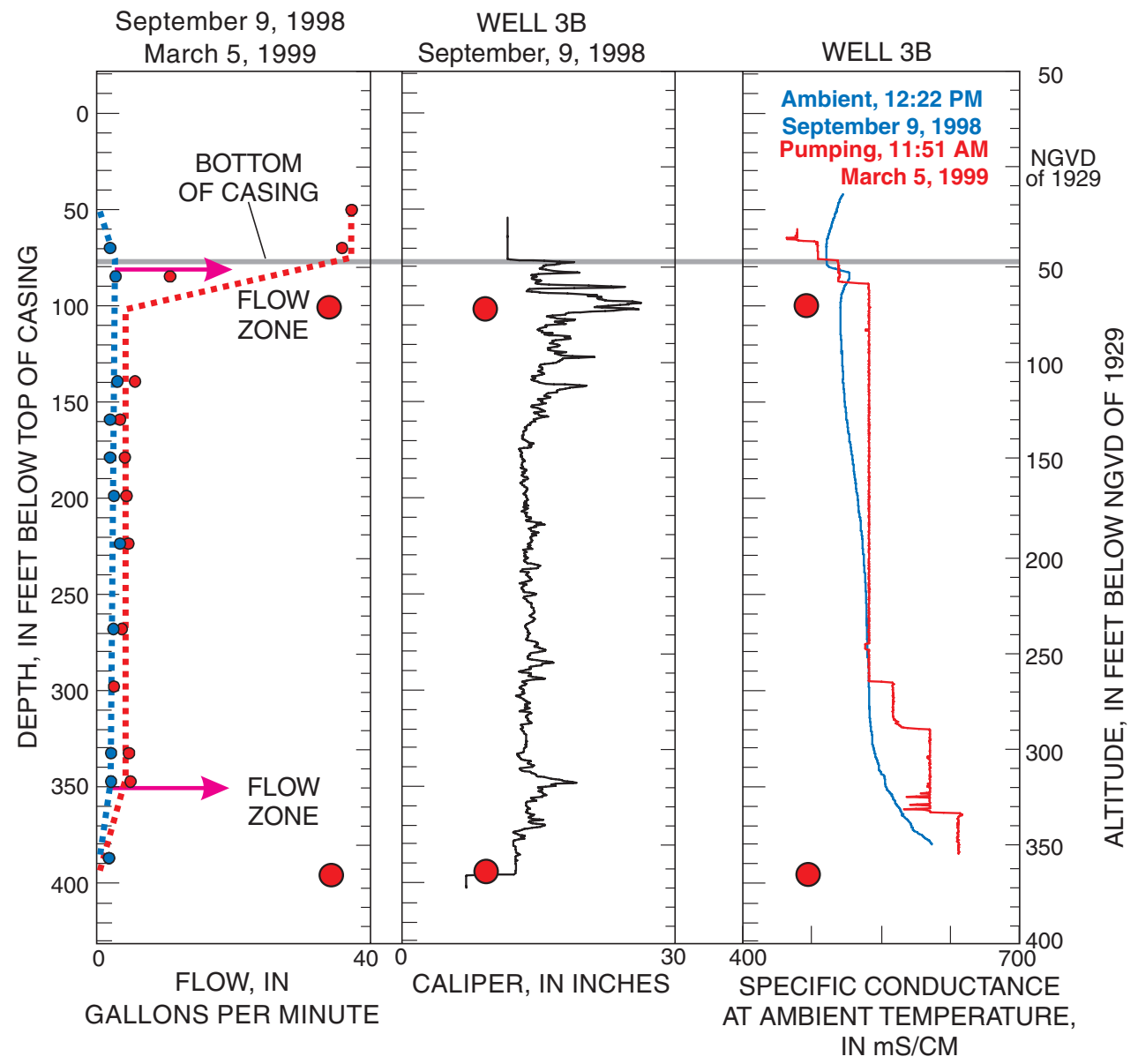

\section{EXPLANATION}

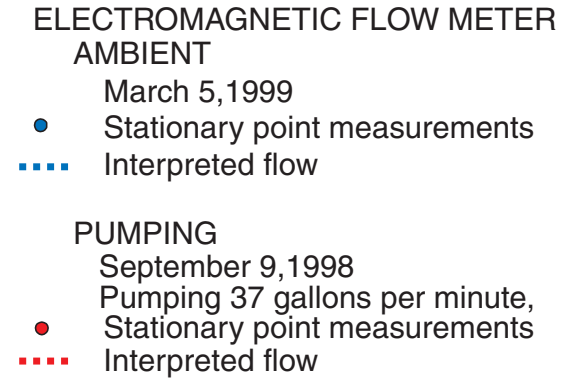

Figure 19. Flow, caliper, and fluid conductance logs at Eldridge-Wilde well 3B. Location of well shown in fig. 2.

$\log$ indicated that a minor flow zone exists at $350 \mathrm{ft}$ below top of casing, and a major flow zone is present beneath the bottom of casing, corresponding to the enlarged section of the borehole. A log of specific conductance under pumping conditions indicates that water from below $300 \mathrm{ft}$ below top of casing has a higher specific conductance than water from shallow depths. As water from the lower flow zone enters the well, it causes an increase in the specific conductance within the borehole. Similar to ambient conditions, under pumping conditions, water with a low specific conductance enters the borehole just below the casing, causing a decrease in the specific conductance (fig. 19).
In well 3B, borehole enlargements correspond to both flow zones where water-quality changes occurred. The majority of inflow occurred within the Tampa Limestone while a minor flow component is associated with the Tampa/Suwannee producing zone. Although the flow within the Tampa/Suwannee producing zone is minor, the specific conductance is higher than the water associated with the Tampa Limestone flow zone. The lower specific capacity of well 3B, when compared to well 2A (40 and $130 \mathrm{gal} / \mathrm{min} / \mathrm{ft}$, respectively), indicates that this well does not intersect additional substantial flow zones. 


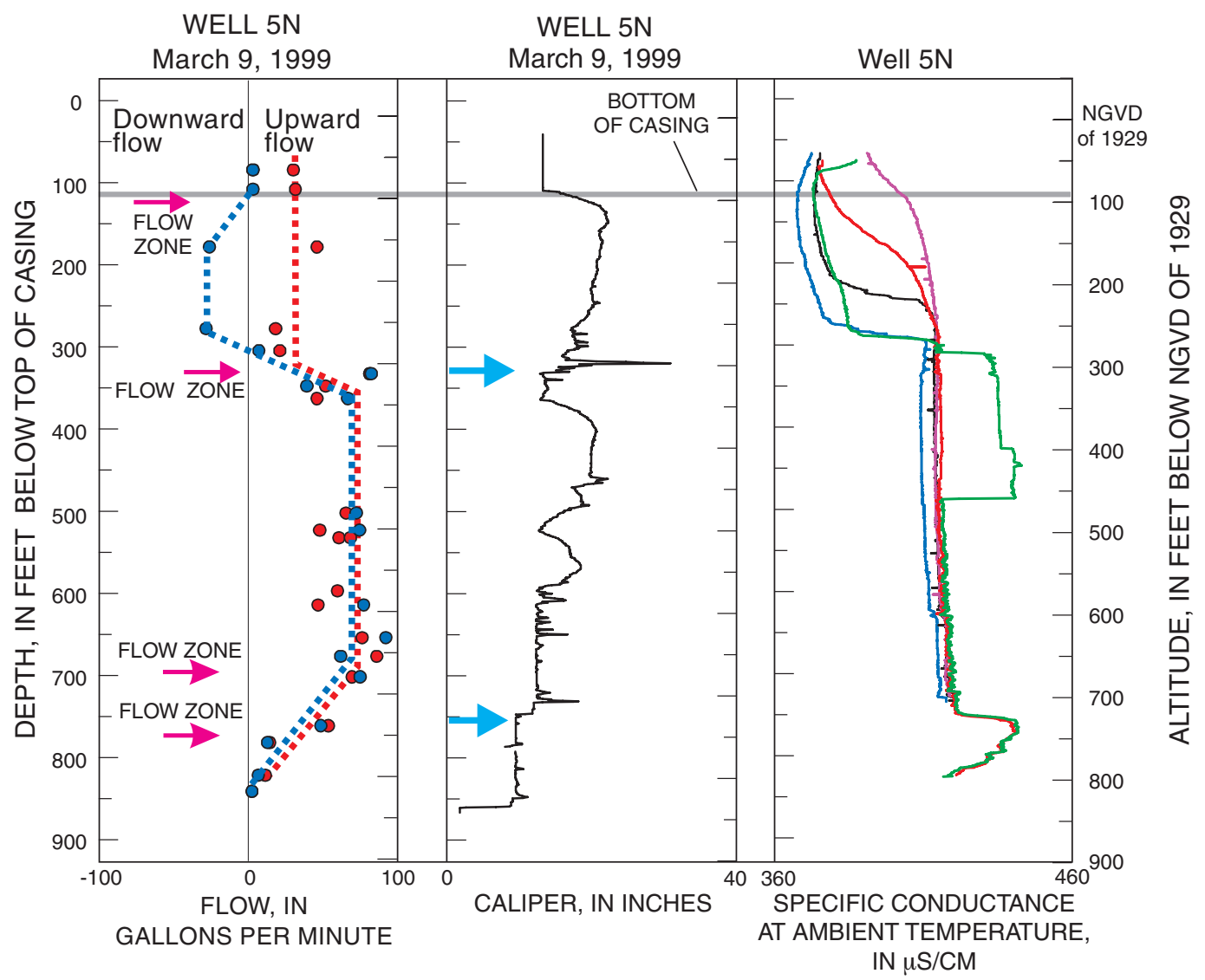

EXPLANATION

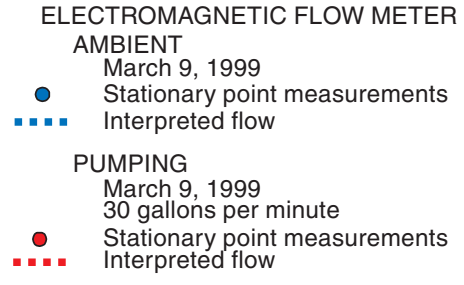

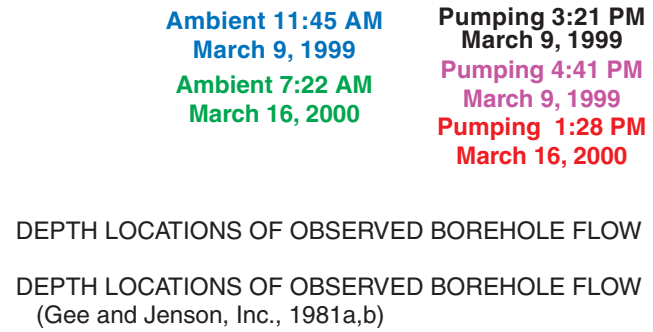

Figure 20. Flow, caliper, and fluid conductance logs at Eldridge-Wilde well 5N. Location of well shown in fig. 2.

Well $5 \mathrm{~N}$ is in the central part of the well field and was deepened into the Avon Park Formation in 1980 (fig. 12). Total depth is $863 \mathrm{ft}$ below land surface with 107 feet of casing (fig. 20). The specific capacity of this well increased from 39 to 122 $\mathrm{gal} / \mathrm{min} / \mathrm{ft}$ when it was deepened (app. A). Ambient and pumping flow logs were collected at well $5 \mathrm{~N}$ using both the EM and the heat-pulse flow-meter tools. An enlarged section of the borehole between 100 and $300 \mathrm{ft}$ below top of casing made flow measurements difficult in this interval. By comparing flow measurements under pumping and ambient conditions, flow was measured across this interval, but exact depths of inflow or outflow were not determined. At the 300-ft-depth interval along the contact between the Suwannee and Ocala Limestones, the borehole was intact and flow measurements were made with consistent responses below this depth. Flow zones were identified at 150, 300-330, 700, and 760-780 ft below top of casing. These flow zones coincide with flow zones previously identified by Gee and Jenson Inc. (1981a,b) (fig. 20). Specific conductance logs indicate that the water-producing zones have differing water-quality properties (fig. 20). Water with the highest specific conductance enters the well at $780 \mathrm{ft}$ below top of casing. Under ambient conditions, freshwater enters the well, most likely from just below casing, and flows downward to the 300-330 ft zone. The highest measured inflow based on two different flow measurement methods on two separate dates, was from the zone at $700 \mathrm{ft}$ below top of casing. Minor flow from the 780-800 ft zone was observed during both ambient and pumping conditions. Both caliper and acoustic 


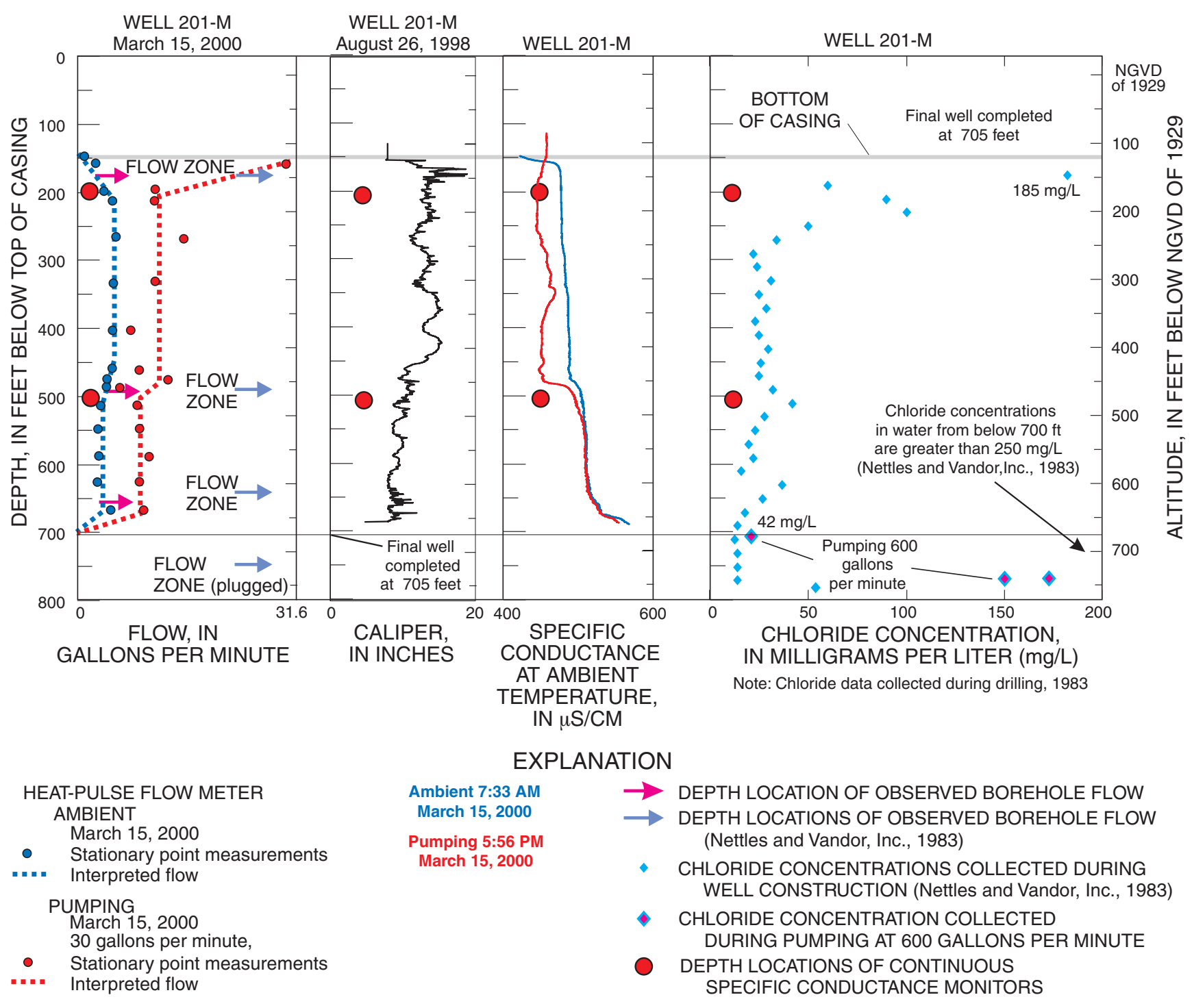

Figure 21. Flow, caliper, and fluid conductance logs and chloride concentrations obtained during drilling at well 201-M west of the Eldridge-Wilde well field. Location of well shown in fig. 2.

televiewer data indicated that fractures were present from approximately 630 to $750 \mathrm{ft}$ below top of casing (figs. 8, 10). The inflow zone between 700 and $750 \mathrm{ft}$ below top of casing corresponded to substantial borehole enlargement and several fractures within the Avon Park producing zone.

Flow measurements can correspond to water-quality changes and can be affected by adjacent pumping stresses. Measurements of flow in well $5 \mathrm{~N}$ under ambient conditions indicated that inflow and outflow occurred in the borehole that might be related to pumping at nearby wells. Logs showed that flow comes into the borehole about $800 \mathrm{ft}$ below top of casing, increases at about $675 \mathrm{ft}$, and then decreases at the $300-330 \mathrm{ft}$ zone, where ground water apparently exits the borehole at the Tampa/Suwannee producing zone (fig. 20). The strong borehole flow under ambient conditions indicates that the $300-330 \mathrm{ft}$ zone may be connected to other wells pumping from that zone.
Specific conductance logs of well $5 \mathrm{~N}$ indicate that changes in specific conductance along the length of the borehole also are related to the amount of flow contributed by each permeable zone (fig. 20). On March 9, 1999, the ambient specific conductance $\log$ showed an increase of approximately $50 \mu \mathrm{S} / \mathrm{cm}$ at $300 \mathrm{ft}$ below top of casing. On March 16, 2000, the ambient specific conductance $\log$ showed a similar increase at the $300 \mathrm{ft}$ zone, with a decrease at $500 \mathrm{ft}$, and another $20-\mu \mathrm{S} / \mathrm{cm}$ increase at $750 \mathrm{ft}$ below top of casing. Although these are small changes, they indicate that water quality varies along the borehole in response to changes in flow along specific permeable intervals. Ambient conditions probably were different for the two logged dates, which likely could affect the relative contributions from each permeable interval. The specific conductance of water from the 300 to $330 \mathrm{ft}$ below top of casing interval is unknown because ground water was exiting the borehole along this permeable 
interval when all flow logs were collected. The slight increase in the ambient specific conductance log on March 16, 2000, however, indicates that the zone may have slightly higher fluid conductivities.

Water from below $750 \mathrm{ft}$ below top of casing has a slightly higher specific conductance than shallower intervals and appears to be diluted as flow moves up the borehole. Although much of the internal flow exits the borehole at the $300 \mathrm{ft}$ depth, water with the higher specific conductance eventually affects the water quality of the uppermost freshwater zone (fig. 20).

Enlarged secondary porosity features correspond to the permeable intervals at well $5 \mathrm{~N}$. Acoustic televiewer data show that enlarged bedding planes account for the enlarged caliper features observed from 300 to $350 \mathrm{ft}$ below top of casing near the contact between the Suwannee and Ocala Limestones (fig. 20). These features transmit substantial quantities of water, and the horizontal orientation may indicate lateral continuity between this flow zone and other production wells. Although some horizontal bedding features exist within the Avon Park Formation, permeable intervals within the Avon Park producing zone are associated primarily with vertically extensive fractures (Hickey, 1982). Enlarged open-hole conditions and a distinct fracture exist within the $5 \mathrm{~N}$ borehole at $700 \mathrm{ft}$ below top of casing. Fractures are present from 650 to $750 \mathrm{ft}$ below top of casing. From 750 to $775 \mathrm{ft}$ below top of casing, enlarged horizontal bedding planes are present but distinct fractures are not observed.

Well 201-M is constructed similarly to deep wells having large open-hole intervals in the northern part of the well field. Well 201-M is less than $1 \mathrm{mi}$ west of the well field and groundwater levels generally are higher than in the well field (figs. 1, $2,15)$. When well-field pumping is high, ground water may flow from this area east toward the well field. Downward flow was observed in the borehole during drilling in 1983 (Nettles and Vandor, Inc.,1983). Historical specific conductance logs at 201-M, collected under ambient conditions on different dates, showed opposite trends. Changes in specific conductance occurred within the upper $300 \mathrm{ft}$ below top of casing and below $450 \mathrm{ft}$ below top of casing. In one log, the specific conductance increased gradually with depth and in the other log, the specific conductance decreased with depth.

At well 201-M, pumping flow logs, collected using the heat-pulse flow meter, showed increased inflow of about $20 \mathrm{gal} / \mathrm{min}$ at $200 \mathrm{ft}$ below top of casing. An increased inflow of about $3 \mathrm{gal} / \mathrm{min}$ occurred at $475 \mathrm{ft}$ below top of casing corresponding to a change in specific conductance. These changes coincide with the Ocala Limestone/Avon Park Formation contact (fig. 21). Specific conductance logs, collected during ambient and pumping conditions on March 15, 2000, showed a specific conductance of about $500 \mu \mathrm{S} / \mathrm{cm}$, with values increasing slightly at approximately $475 \mathrm{ft}$ below top of casing and increasing with depth below $475 \mathrm{ft}$. Under pumping conditions, the specific conductance log on March 15, 2000, showed increasing values with depth, with better definition of distinct water-quality changes and associated depth zones corresponding to flow zones measured by Nettles and Vandor, Inc. (1983).
At well 201-M, the flow zones are associated with enlarged borehole sections within the Tampa /Suwannee, the Ocala/Avon Park, and the Avon Park producing zones. Limited acoustic televiewer data from 480 to $680 \mathrm{ft}$ below top of casing identified 11 fractures within the Avon Park Formation, ranging in dip angle from 63 to 82 degrees (fig. 8). These fractures are in conjunction with enlarged horizontal bedding planes, which appear to be the structural control for the enlarged borehole intervals.

\section{Sources and Variability of Chloride in Ground Water}

The variability of chloride in ground water within the study area results from the influence of nearby sources for chloride ions and the variable mixing of three water types: calciumbicarbonate, sodium-chloride, and calcium-sulfate. The two most likely sources for chloride in the well field are seawater and deep mineralized ground water (fig. 22a,b). Because seawater contains chloride concentrations that are higher than other available sources, even small contributions of seawater can substantially affect concentrations in ground water. Sources of chloride at concentrations with a similar magnitude to seawater, such as those associated with residual saline water, halite solution, natural saline water, oil and gas brines, agricultural effluent, or saline seeps, have not been found in the hydrogeologic framework of the study area (Sprinkle, 1989; Richter and Kreitler, 1993). Seawater contains approximately 19,000 mg/L of chloride (approximately 50,000 $\mu \mathrm{S} / \mathrm{cm}$ specific conductance). In nearly all coastal areas within Florida, wells that fully penetrate the UFA have chloride concentrations approaching that of seawater (Sprinkle, 1989). Ground water with specific conductance greater than $10,000 \mu \mathrm{S} / \mathrm{cm}$ and chloride concentrations greater than $15,000 \mathrm{mg} / \mathrm{L}$ is present at $700-750 \mathrm{ft}$ below land surface less than $2 \mathrm{mi}$ south and west of the EW well field (figs. 1, 2).

The lateral inland movement of modern seawater (lateral encroachment) has been recognized as a source of chloride in ground water throughout Florida (Cooper and others, 1964; Trommer, 1993; Southwest Florida Water Management District, 1996b; Barlow, 2003). In coastal regions, seawater encroachment occurs when ground-water levels in an aquifer are lowered, reversing head gradients and allowing seawater to displace freshwater (fig. 22a). Ground-water levels are lowered during pumping, especially under drought conditions (Cooper and others, 1964).

Another potential source of chloride is deep ground water that is ion enriched, reflecting long ground-water residence times in contact with aquifer minerals in the regional flow system (Sprinkle, 1989). Although chloride ions accumulate along ground-water flow paths, they do not commonly reach levels similar to seawater concentrations. Deep ground water becomes ionically enriched as rock-water interactions increase the total dissolved solids (TDS) and the overall salinity of ground water. Chloride is enriched in deep ground water because it is a conservative ion and is seldom removed by 

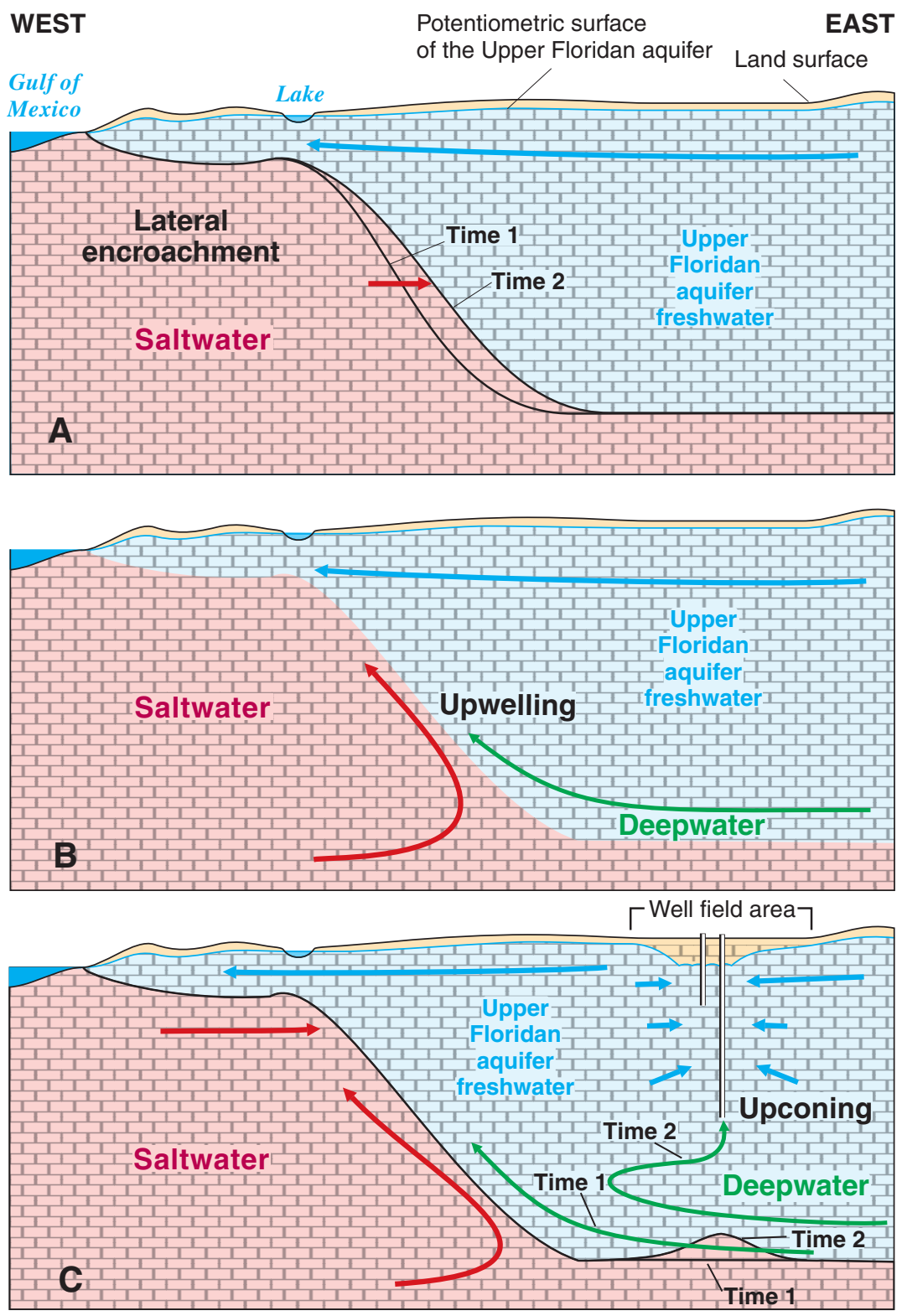

\author{
EXPLANATION \\ DIRECTION AND TYPE OF \\ GROUND-WATER MOVEMENT
}

$\longleftarrow$ Saltwater (sodium-chloride)

$\longleftarrow$ Freshwater (calcium-bicarbonate)

$\longleftarrow$ Deepwater (calcium-sulfate)

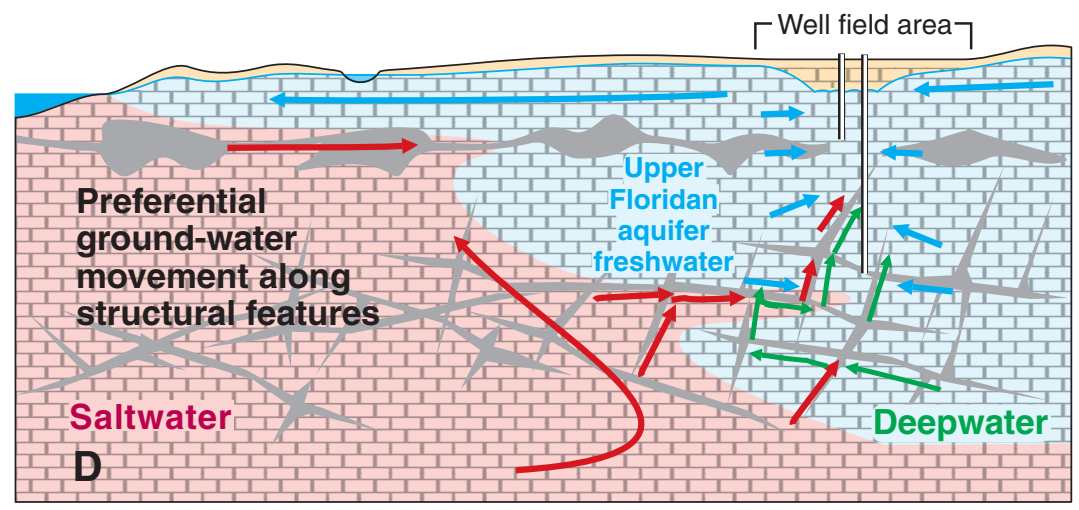

Figure 22. Schematic sections illustrating possible physical processes for movement and introduction of chloride within the fresh ground-water system of the Upper Floridan aquifer: (A) lateral encroachment of the saltwater/freshwater interface, (B) upwelling of deep mineralized ground water along the boundary of the saltwater interface, (C) upconing induced by ground-water withdrawals, and (D) localized movement of ground water along fractures and permeable intervals. 
geochemical reactions (Sprinkle, 1989; Richter and Kreitler, 1993). Gypsum dissolution and ground-water movement along the base of the UFA typically enriches deeper ground water with calcium, sulfate, and chloride. Chloride and sulfate concentrations in a representative deep ground-water sample from the top of the MCU within the study area were 290 and $1,800 \mathrm{mg} / \mathrm{L}$, respectively.

In discharge areas, ground water within the UFA from deep regional flow paths has the potential to move upward (a process known as upwelling) into shallower parts of the aquifer as it approaches the denser saltwater (fig. 22b). This process is part of regional ground-water flow and is a common phenomenon in coastal regions, including west-central Florida (Cooper and others, 1964; Miller, 1986; Bush and Johnston, 1988; Sprinkle, 1989; Maddox and others, 1992; ERM, 2000; Barlow, 2003). Even if natural upwelling does not occur, the presence of ionically enriched water at depth can provide a source for increased concentrations of chloride and other ions within potable ground-water supplies.

Another mechanism that may introduce deep mineralized water into fresh ground-water resources is upconing. Groundwater withdrawals, and the associated changes in potentiometric head gradients, can induce upconing. Upconing is a process by which pressure head gradients induce upward movement of deep ionically enriched water into the freshwater aquifer (fig. 22c). The presence of elevated sulfate concentrations is a common indicator of the chemical influence of the upconing process.

Along the coast, ground-water chemistry is influenced both by seawater and deepwater. Where aquifer units are heterogeneous, higher salinity ground water can flow preferentially through zones of enhanced permeability either by upward or lateral movement when water levels in the upper zones (Tampa/Suwannee) of the UFA are lowered relative to deeper zones (Ocala/Avon Park) (fig. 22d).

Increases in chloride concentrations observed in wells within the southwestern part of the EW well field indicate that a source of chloride exists near the well field; however, changes in chloride concentrations can vary significantly between wells and over time. Chloride trends determined for the same well can indicate no trend or both an increasing and decreasing trend, depending on the statistical techniques and period of record used for analysis (Nettles and Vandor, Inc., 1988b; SDI Environmental Services Inc., 1993; Southwest Florida Water Management District, 1995, 1996a,b, 2000a,b; Yobbi and others, 1996; Montgomery Watson Americas, Inc., 2001; Water and Air Research, Inc. and others, 2001).

\section{Temporal and Spatial Variations}

Temporal and spatial variations in chloride concentrations within the study area were examined by analyzing chloride concentrations at selected wells over time and examining annual isochlor maps from 1975 through 2001. Examples of temporal trends in chloride concentration from selected wells are shown in figure 23. Chloride levels at well $2 \mathrm{~A}$ reached a maximum of $111 \mathrm{mg} / \mathrm{L}$ in 1989. Annual average chloride concentrations in selected wells at the well field increased from $10 \mathrm{mg} / \mathrm{L}$ in 1975 to more than $70 \mathrm{mg} / \mathrm{L}$ in 1995 (Leggette, Brashears and Graham, 1995, 1996; Water and Air Research, Inc. and others, 2001) (fig. 24), which represents a 600-percent increase; this is not the maximum reported value but an annual average of reported monthly values. Chloride concentrations at selected wells began increasing gradually in the late 1970s and 1980 s, but the rate of increase became more rapid in the late 1980s and early 1990s coincident with the deepening of wells into the Avon Park Formation.

Chloride concentrations in ground water near the well field have been monitored in wells between Lake Tarpon and the EW well field (fig. 1). Southwest of the well field, the $250-\mathrm{mg} / \mathrm{L}$ isochlor, representing the upper boundary of the saltwater/ freshwater interface, is less than $300 \mathrm{ft}$ deep (Southwest Florida Water Management District, 1990). Ground water from a well adjacent to Salt Lake Bayou (WRAP 37F, fig. 1), with an open hole 64 to $74 \mathrm{ft}$ below land surface, currently has chloride concentrations near $1,000 \mathrm{mg} / \mathrm{L}$ and has shown an increasing trend from approximately 800 to $1,000 \mathrm{mg} / \mathrm{L}$ from 1991 to 2000 (Southwest Florida Water Management District, 2000b). From 1970 to 1996 , increasing chloride concentrations also were observed in ground water 2 - 3 mi south and west of the EW well field. At the NLKTP well (tapping the Avon Park producing zone) and the TPRDDP well (tapping the Tampa/Suwannee producing zone), chloride concentrations increased from 8,000 to $18,000 \mathrm{mg} / \mathrm{L}$ and from 50 to $65 \mathrm{mg} / \mathrm{L}$, respectively (Yobbi and others, 1996: see fig. 2 for well locations). At the TPRDDP well, analysis of chloride concentrations from 1978 to 1999 indicated increasing trends with concentrations ranging from 44 to $70 \mathrm{mg} / \mathrm{L}$ (Causseaux and Fretwell, 1982; Trommer, 1993; Yobbi and others, 1996). Increasing trends from 1991 to 2000 also were observed in the Avon Park producing zone southwest of the well field (well WRAP-1D), where chloride concentrations increased from 900 to $1,300 \mathrm{mg} / \mathrm{L}$, and northwest of the well field (well WRAP-3D), where chloride concentrations increased from 900 to $1,000 \mathrm{mg} / \mathrm{L}$. Farther south (well WRAP4D), chloride concentrations were lower and showed a smaller increase from 25 to $30 \mathrm{mg} / \mathrm{L}$ (Southwest Florida Water Management District, 2000b).

Within the well field, temporal trends were determined for each well. Chloride-concentration trends for the period of record were characterized by the type of variability in the data, whether concentrations increased above $20 \mathrm{mg} / \mathrm{L}$, and whether the concentrations were constant or fluctuated monthly. Type- 0 wells show no increase and little variability in chloride concentrations. Type-1 wells have a consistent, well-defined increase in chloride concentrations over $20 \mathrm{mg} / \mathrm{L}$. Type- 2 wells have fluctuating monthly chloride concentrations, possibly with distinct spikes but an overall increase in chloride concentration greater than $20 \mathrm{mg} / \mathrm{L}$. Type-3 wells show no increase (generally below $20 \mathrm{mg} / \mathrm{L}$ ) with low variability, but have distinct spikes in chloride concentrations, representing discrete pulses of water with elevated chloride concentrations entering the well (fig. 23). 

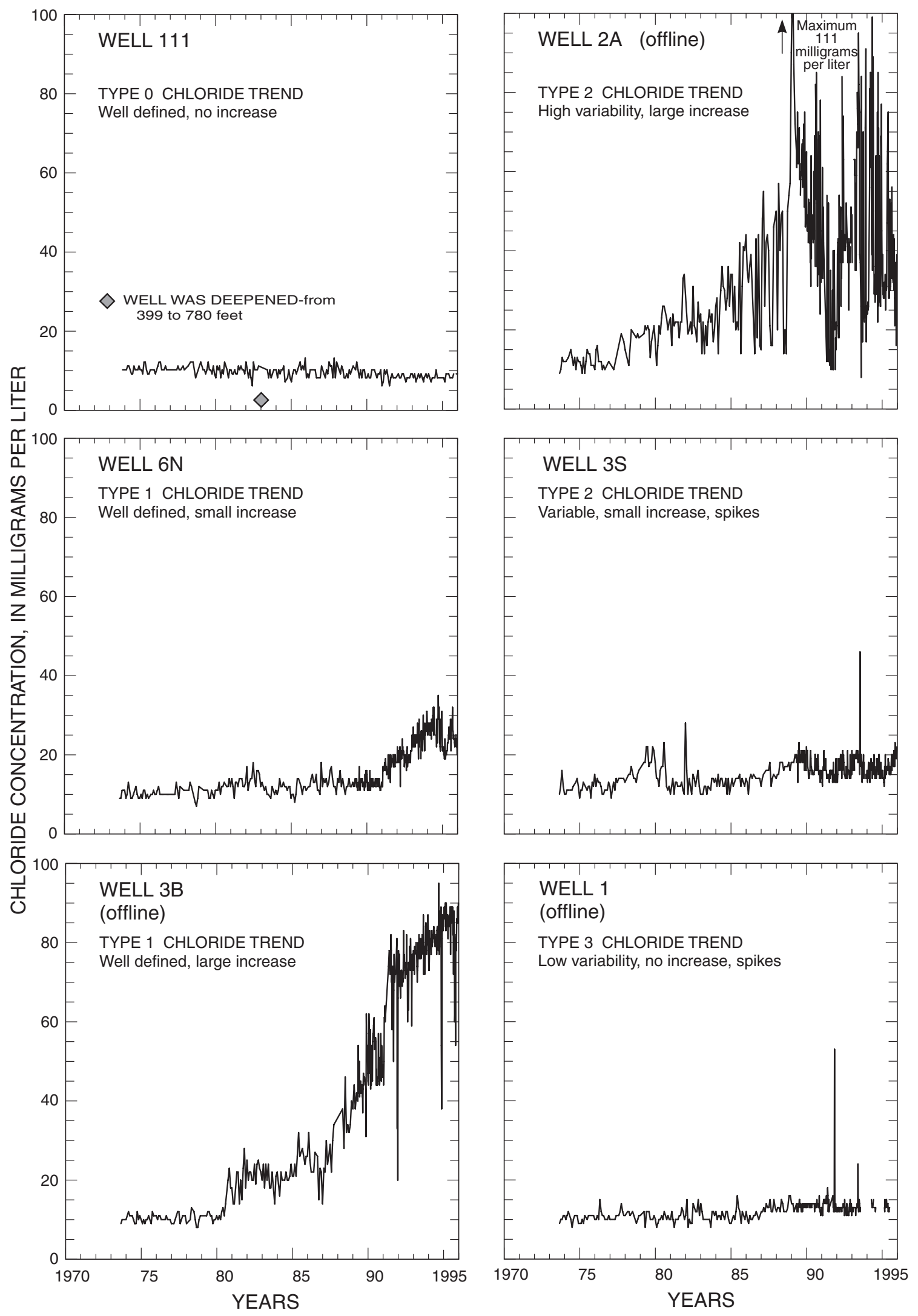

Figure 23. Chloride concentrations and types of trends identified in water from the Upper Floridan aquifer in selected wells at the Eldridge-Wilde well field. Locations of wells shown in fig. 2. 
1995

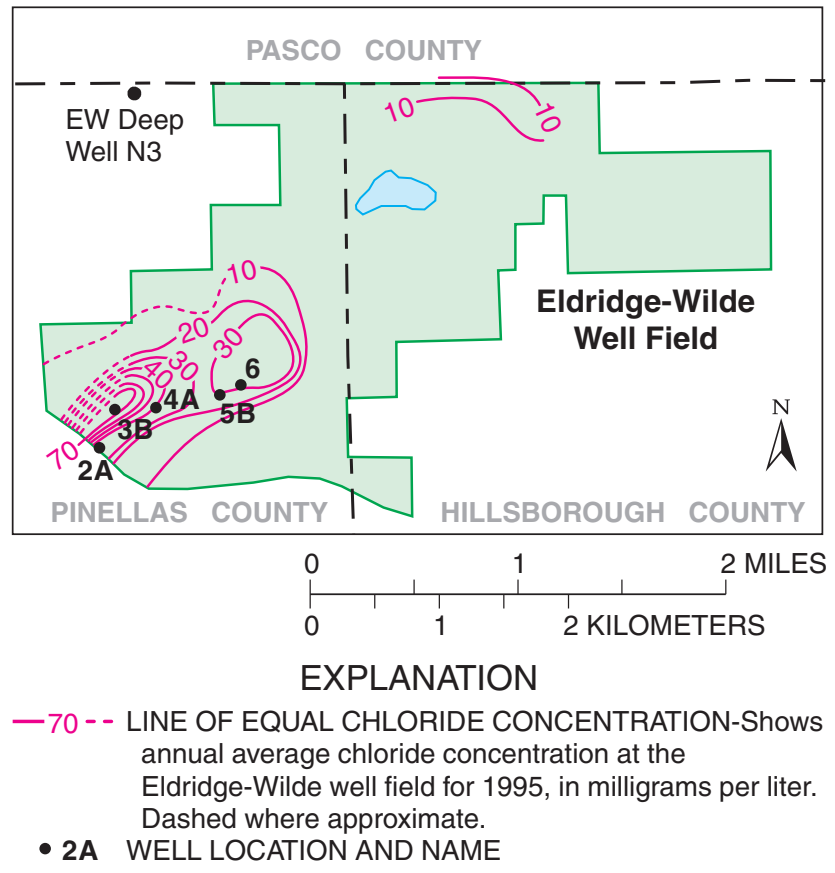

Figure 24. Distribution of annual average chloride concentrations in water from the Upper Floridan aquifer at the EldridgeWilde well field for 1995. Modified from Water and Air Research and others (2001).

The increased depth of production and capacity of the well field were accompanied by increases in specific conductance (caused by increasing chloride and sulfate concentrations) in a number of production wells. The greatest increases in chloride concentrations were observed during the late 1980s and early 1990s, as the well-deepening program was completed and the deeper wells tapping the Avon Park producing zone were brought online (figs. 13, 23). Maximum chloride concentrations were not observed in wells penetrating the Avon Park producing zone, but were found in wells in the southwestern part of the well field that generally were less than $500 \mathrm{ft}$ deep (Water and Air Research, Inc. and others, 2001).

Spatial variations in chloride concentrations within the study area were analyzed by examining the annual isochlor maps from 1975 through 2001. The annual average isochlor contours, like the potentiometric-surface contours, are oriented northeast-southwest through the well field. The highest chloride concentrations are centered over wells $3 \mathrm{~B}$ and 6 , near the maximum cone of depression in the potentiometric surface located near high-pumping wells 4A and 5B (fig. 24). An overlay of the potentiometric-surface maps and the average chloride concentrations at the production wells for 1976 and 1980 shows that the greatest increases in chloride concentrations coincide with the area of the well field where the deepest part of the cone of depression occurs (fig. 25). During the late 1980s and early 1990s, some wells had greater increases in chloride concentra- tions than others. The largest increases in chloride concentrations were within the southwestern part of the well field in the vicinity of the cone of depression (figs. 24, 25).

Changes in the regional potentiometric surface from predevelopment conditions to 2000 show that water levels have been lowered within the region between the EW well field and the coast (fig. 14). As a result, it is likely that both the rate and direction of ground-water flow, especially within the southwestern part of the well field, have changed. Increasing chloride

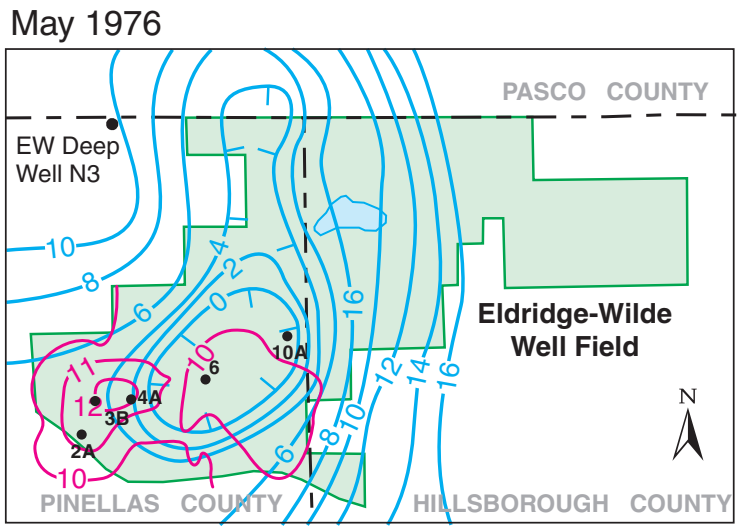

May 1980

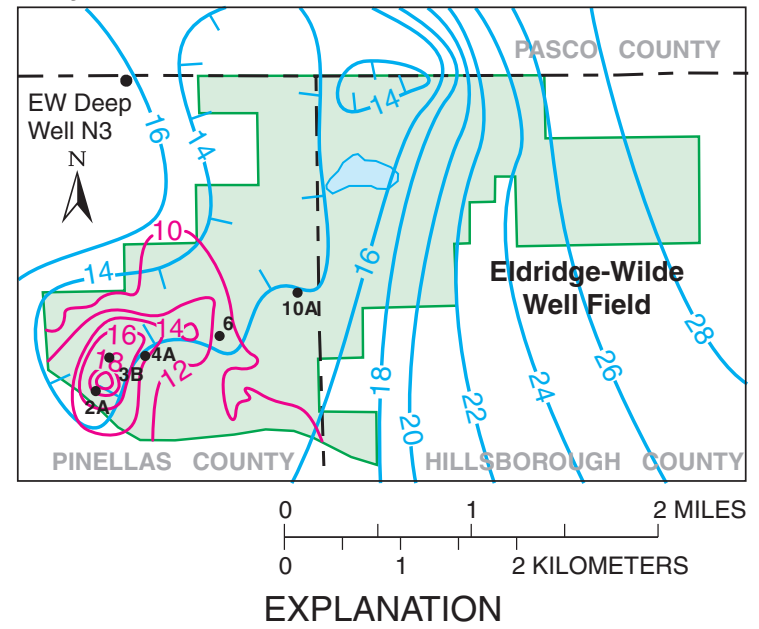

-20- POTENTIOMETRIC CONTOUR-Shows altitude at which water level would have stood in tightly cased wells, in feet above NGVD of 1929. Contour interval, 2 feet. Hachures indicate depression. Datum is NGVD of 1929.

-12- LINE OF EQUAL CHLORIDE CONCENTRATION-Annual average chloride concentration in ground water from production wells at the Eldridge-Wilde well field for years 1976 and 1980, in milligrams per liter.

- 10A WELL LOCATION AND NAME

Figure 25. Relation between the potentiometric surface of the Upper Floridan aquifer and chloride concentrations in ground water from the Upper Floridan aquifer at the Eldridge-Wilde well field. 


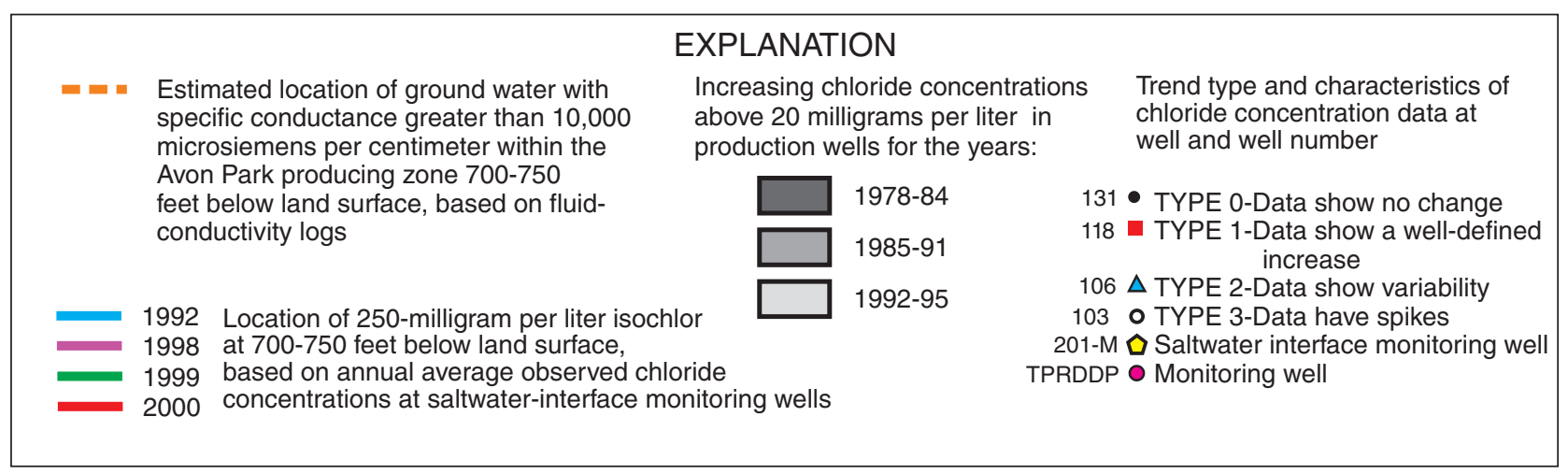

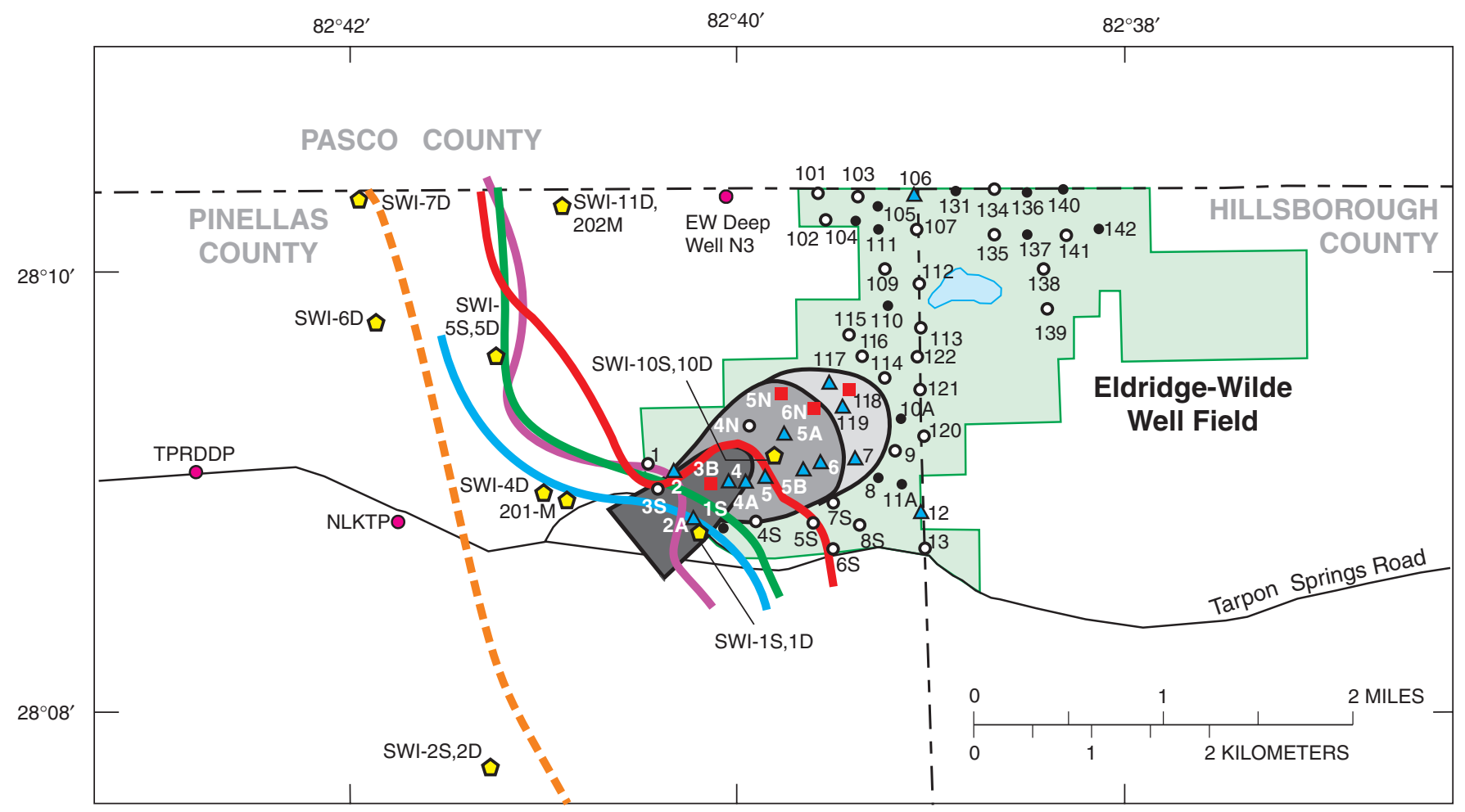

Figure 26. Temporal and spatial distribution of chloride concentrations in ground water from the Upper Floridan aquifer at the EldridgeWilde well field, including the type of chloride concentration trend, where and when chloride concentrations exceeded $20 \mathrm{mg} / \mathrm{L}$ and isolines for the $250-\mathrm{mg} / \mathrm{L}$ chloride concentration and the $10,000-\mu \mathrm{S} / \mathrm{cm}$ specific conductance values. Location of $250-\mathrm{mg} / \mathrm{L}$ isochlor modified from Water and Air Research, Inc., and others (2001).

concentrations within the Tampa/Suwannee producing zone observed at well TPRDDP indicate that chloride may be moving along this producing zone. Increases in the specific conductance logs observed at this depth interval at wells $2 \mathrm{~A}$ and $3 \mathrm{~B}$, and the presence of elevated chloride concentrations observed between 150 and $250 \mathrm{ft}$ below land surface at well 201-M during drilling (fig. 21), also indicate that higher chloride concentrations may occur along this producing zone.

Chloride concentrations varied temporally and spatially at the well field (fig. 26). The four type-1 wells, showing welldefined increases in chloride concentrations, are $3 \mathrm{~B}, 5 \mathrm{~N}, 6 \mathrm{~N}$ and 118: these four wells are within the central area of the southwestern part of the well field. This is the same area that shows a northeast-southwest trend in the isochlor map and the depressed potentiometric surface shown in figure 25. Surrounding these wells are 11 type- 2 wells, characterized by increasing chloride trends but with a more variable range. Type- 3 wells are characterized by spikes in chloride concentrations and are found throughout the well field. Data from types 2 and 3 indicate that ground water with elevated chloride concentrations migrates into the well field, but only periodically enters the capture zone of each production well. Wells showing no change in chloride concentrations (type-0) are located predominantly in the northern part of the well field (fig. 26). 


\section{Effects of Aquifer Heterogeneity on Ground-Water Flow and Chloride Concentrations, West-Central Florida}

Chloride concentrations in production wells first increased above $20 \mathrm{mg} / \mathrm{L}$ in the southwestern part of the well field during the period from 1978 to 1984 , then concentrations increased toward the northeast from 1985 to 1995 (fig. 26). Declines of more than $10 \mathrm{ft}$ in the potentiometric surface have been observed since 1972 (fig. 15). These potentiometric changes coincided with the first increases in chloride concentrations observed in production wells in the southwestern part of the well field. During the early 1990s, chloride concentrations in these wells increased more rapidly than those in other areas of the well field. Maximum chloride concentrations greater than $100 \mathrm{mg} / \mathrm{L}$ were observed in water from wells $2 \mathrm{~A}$ and 3B.

Although wells in the central part of the well field also showed increases in the early 1990s, concentrations typically were less than $40 \mathrm{mg} / \mathrm{L}$.

The type of chloride trend identified in a production well corresponds to the well's location (fig. 26). Wells with clearly increasing trends in chloride concentrations are located more toward the center of well field. Wells that exhibit increased chloride concentrations but with greater variability are located closer to the well-field boundaries. The $250-\mathrm{mg} / \mathrm{L}$ isochlor in the Avon Park Formation (700-750 ft below land surface) shows northeasterly movement from the southwestern part of the well field along the same central axis as the observed increases in chloride concentrations at the production wells; however, the location of the isochlor appears to have oscillated over time.

In seawater mixtures, the chloride concentration and specific conductance are consistently related and, therefore, specific conductance can be used to indicate chloride concentrations (Ron Miller, U.S. Geological Survey, written commun., 2000). At the saltwater interface, increases in specific conductance can be attributed to increases in chloride concentrations. Therefore, near the saltwater interface, increases in specific conductance indicate saltwater mixing. Increases in sulfate associated with deepwater mixing, however, can elevate specific conductance above the seawater mixing line. Therefore, inland of the saltwater interface, increases in specific conductance can be attributed to mixing with both saltwater and deepwater.

Temporal changes in specific conductance in ground water were observed in logs and in continuous data collected at fixed depths in selected wells. Continuous specific conductance data were collected by the USGS, in cooperation with Pinellas County, from 1993 to 1998 at sites SWI-1S, SWI-1D, SWI-7D, SWI-10S, and SWI-10D to analyze the movement of the saltwater/freshwater interface over time (figs. 27-30). These wells are named with the prefix "SWI" (for saltwater interface), because they were specifically constructed to monitor the saltwater/freshwater interface within and surrounding the EW well field. Each well was equipped with a specific conductance probe set at a selected depth within the Avon Park Formation $(500,670,680,700,730$, or $850 \mathrm{ft}$ below land surface). In four of the five wells, specific conductance fluctuated daily. In many cases, increases in specific conductance were associated with ground-water level declines, but not always.
Continuously monitored wells that were closer to the saltwater interface and that had open-hole intervals penetrating the fractured Avon Park producing zone showed the greatest ranges and the largest increases in specific conductance. Within the Avon Park producing zone, increases in specific conductance always occurred as water levels declined, but the changes in specific conductance ranged from less than $100 \mu \mathrm{S} / \mathrm{cm}$ at well SWI-10D to more than $10,000 \mu \mathrm{S} / \mathrm{cm}$ at well SWI-7D (figs. 30 and 29 , respectively). At the 500-ft depth (well SWI-1S), specific conductance ranged from about 600 to more than 700 $\mu \mathrm{S} / \mathrm{cm}$, but at greater depths, increased more than $1,000 \mu \mathrm{S} / \mathrm{cm}$ (wells SWI-1D, SWI-10S, SWI-7D). At SWI-1S and SWI-10S, the greatest increases in specific conductance coincided with periodic water-level declines (figs. 27 and 30, respectively). At SWI-1D, tidal effects influenced both water levels and specific conductance, although the tidal signature sometimes was overwhelmed (fig. 28). Tidal effects caused water levels to change nearly $2 \mathrm{ft}$ and specific conductance to range approximately 100 $\mu \mathrm{S} / \mathrm{cm}$ over a complete tidal cycle (fig. 28 ). Although changes in water levels associated with tidal cycles were correlated with changes in specific conductance, the changes related to the tidal signal were superimposed on longer-term trends in both the water-level and specific conductance data. Similar tidal effects were not observed at the other continuous monitoring sites.

The greatest changes in specific conductance were observed at SWI-7D as water levels declined. Ground-water levels higher than $14 \mathrm{ft}$ above NGVD of 1929 generally corresponded to a constant specific conductance value (near 5,000 $\mu \mathrm{S} / \mathrm{cm}$ ), but when water levels declined below this level, specific conductance values increased by an order of magnitude, approaching that of seawater (fig. 29). Similar responses to water-level changes occurred at wells SWI-1S and SWI-10S (figs. 27 and 30, respectively), although the increases in specific conductance were not as large as those observed at SWI-7D.

During the study, three additional wells (2A, 3B and 201-M) were instrumented to collect continuous specific conductance data from two fixed-depth intervals from December 1999 through January 2001 (fig. 31). Changes in the specific conductance of ground water over time at specific depth intervals were associated with changes in water levels and pumping. Wells 2A and $3 \mathrm{~B}$ were selected because they have the highest chloride concentration values (maximum values exceeded $80 \mathrm{mg} / \mathrm{L}$ ) and are located within the well-field cone of depression (figs. 15, 25). Well 201-M was selected to observe effects outside of the well field. During the low water levels of May 2000, water-level data were not available at wells $2 \mathrm{~A}$ and $3 \mathrm{~B}$ because of instrumentation problems related to the low water levels. Therefore, data from nearby well $2 \mathrm{~S}$ were used to indicate the approximate water levels for the area near those wells.

Water-quality changes recorded in the boreholes reflect the influence of dominant flow zones. In general, changes in water levels at wells 2A, 3B, and 201-M were accompanied by changes in specific conductance similar to those observed at the SWI wells previously discussed, in that the highest recorded specific conductance values at all three wells corresponded to the greatest declines in water levels and the highest reported 


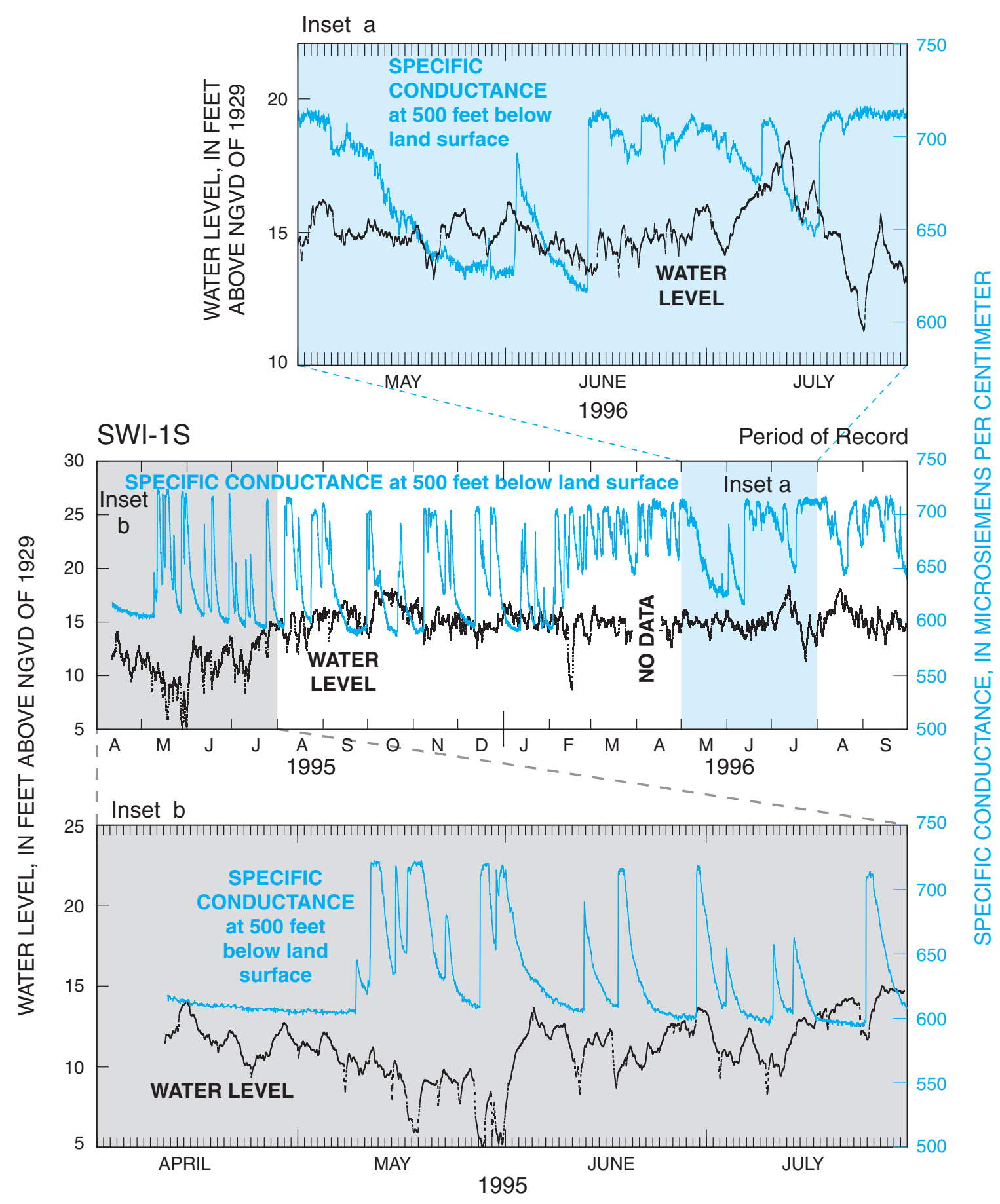

Figure 27. Water levels and specific conductance of water from fixed depths at well SWI-1S, April 1995-September 1996.

pumpage values (figs. 27-30). The presence of an additional fresh flow zone near the top of the casing at well $2 \mathrm{~A}$ appears to keep the overall specific conductance in the borehole at well $2 \mathrm{~A}$ lower than well 3B. Both wells appear to be connected to a flow zone between 290 and $350 \mathrm{ft}$ below land surface where the water has a specific conductance of about $800 \mu \mathrm{S} / \mathrm{cm}$ (figs. 18, 19). At well 3B, however, the two monitored depths responded inversely to each other with the specific conductance sensor at the 100-ft depth recording decreases while the sensor at the 390-ft depth recording slight increases (fig. 31b). Data from well 3B indicate two flow zones with different specific conductance-a shallow zone with a low specific conductance and a deep zone with a high specific conductance. With a baseline specific conductance of about $800 \mu \mathrm{S} / \mathrm{cm}$, it appears that little dilution by other flow zones occurs in this well. By comparison, at well 2A, baseline specific conductance was between 400 and 


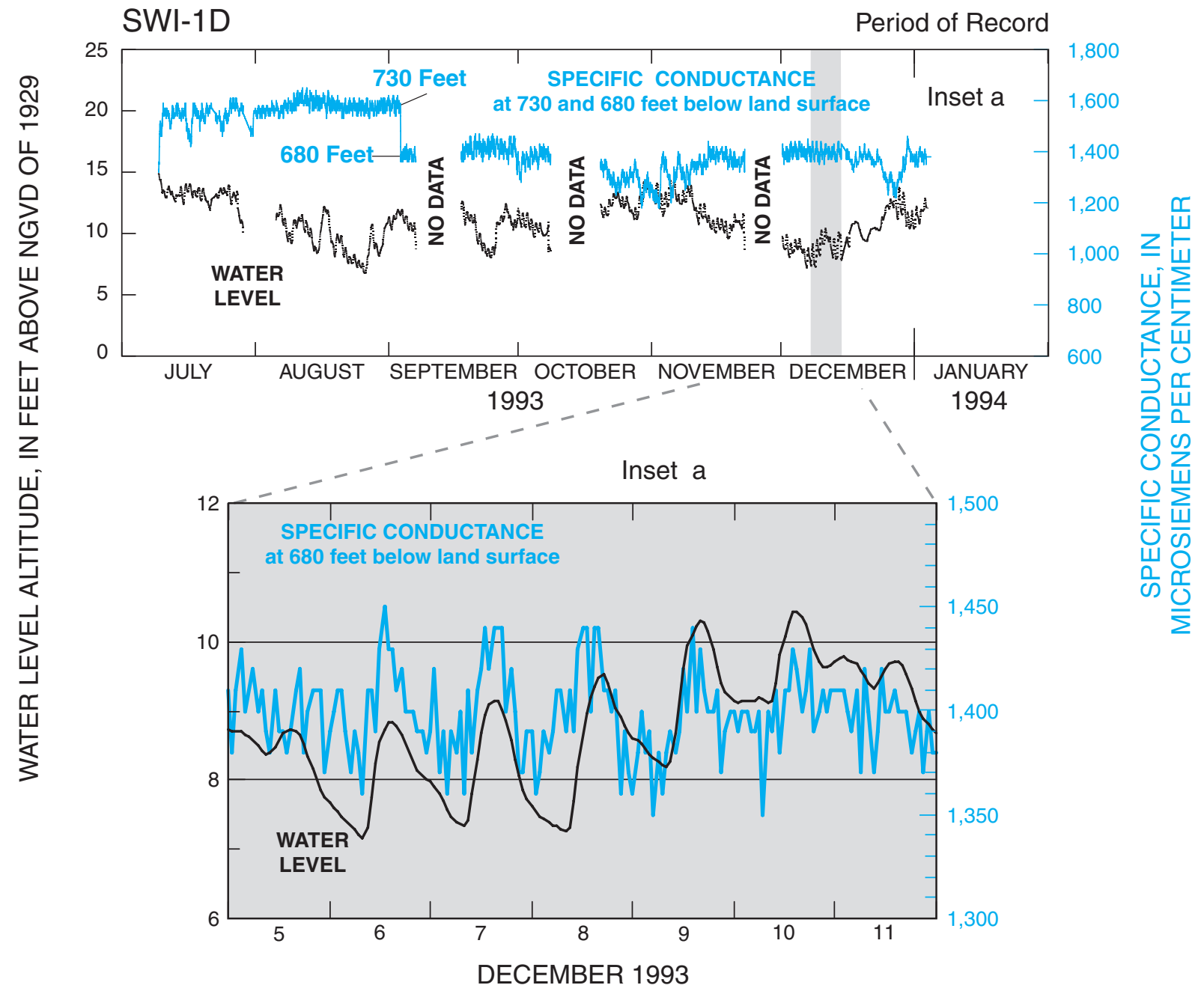

Figure 28. Water levels and specific conductance of water from fixed depths at well SWI-1D, July 1993-January 1994.

$500 \mu \mathrm{S} / \mathrm{cm}$ with only intermittent values reaching about $800 \mu \mathrm{S} / \mathrm{cm}$. The trend in water quality within the borehole at well 2A is controlled by a specific flow zone identified at $290 \mathrm{ft}$ below top of casing using borehole flow and specific conductance log data (fig 18a). The continuous monitoring sensors were located above and below the flow zone. The shallow sensor at $200 \mathrm{ft}$ recorded events that occurred as high conductance water entered the well at 290-300 ft and moved up the borehole, exiting below the top of the casing along another flow zone.

Total daily pumpage at production wells 1-13 (a total of 26 wells), in the southwestern part of the well field, was compared to daily rainfall and water-level response at wells $2 \mathrm{~A}$, 3B, 201-M and 2S (fig. 32). Pumpage in the northern part of the well field was not considered, but may have a measurable affect on the changes observed at wells 2A, 3B, and 201-M. During this study, pumping in the southwestern part of the well field was relatively low, averaging less than $10 \mathrm{Mgal} / \mathrm{d}$, except during the dry season (May) when ground-water pumping increased in response to increased demand.
The highest reported pumpage coincides with the dry season and the lowest ground-water levels (December 1999 to June 2000; fig. 32). During the wet season (June through early September 2000), water levels increased and pumping was less; however, in late September and early October 2000, pumpage exceeded $15 \mathrm{Mgal} / \mathrm{d}$ (fig. 32). From January to August 2000, water levels at 201-M generally were about $2 \mathrm{ft}$ higher than those at wells $2 \mathrm{~A}$ and $3 \mathrm{~B}$, indicating lowered water levels associated with pumpage at the EW well field (fig. 32). Water levels at well 2A generally were lower than those at 201-M, but generally higher than at well 3B. The head difference between wells $2 \mathrm{~A}$ and $3 \mathrm{~B}$ was used to indicate the potential for ground-water flow between these two wells and, consequently, the extent that water quality might be affected by ground-water flow from the west where increased chloride concentrations are present at shallow depths. When water levels at $2 \mathrm{~A}$ are lower than at $3 \mathrm{~B}$, the head difference is negative and the flow gradient is southwest toward well $2 \mathrm{~A}$. When water levels at $2 \mathrm{~A}$ are higher than at $3 \mathrm{~B}$, the head difference is positive and the flow gradient is toward northeast well 3B. During most of the study, the flow 


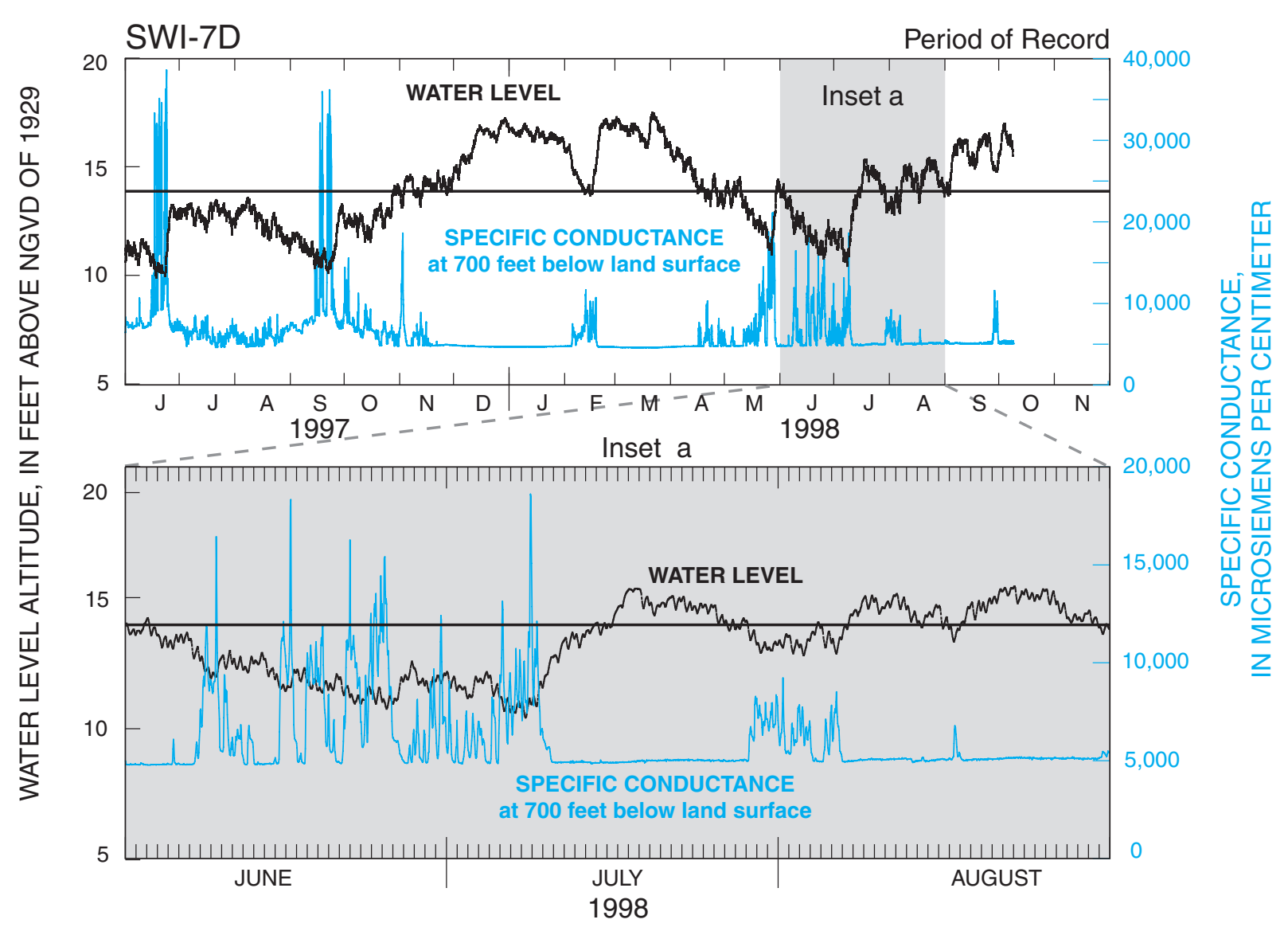

Figure 29. Water levels and specific conductance of water from fixed depths at well SWI-7D, June 1997-December 1998.

gradient between wells $2 \mathrm{~A}$ and $3 \mathrm{~B}$ was northeast toward $3 \mathrm{~B}$ (fig. 32). The average head difference between wells 2A and 3B was $0.5 \mathrm{ft}$, and the maximum was $4.5 \mathrm{ft}$.

Periods of greatest pumpage generally were associated with a greater head difference between wells $2 \mathrm{~A}$ and $3 \mathrm{~B}$. During periods of decreased pumpage, the head difference between wells 2A and 3B was more variable. Decreased pumpage occurred during periods of increased rainfall and water levels (fig. 32). When large head differences existed between wells $2 \mathrm{~A}$ and $3 \mathrm{~B}$, which occurred at the end of September and early October 2000, the specific conductance measured at both depths in well 3B approached $800 \mu \mathrm{S} / \mathrm{cm}$, indicating more water was coming from the lower flow zone (fig. 33). When water levels recovered at well 3B, neither flow zone dominated. From late October 2000 to January 2001, when pumping was low and head differences between 2A and 3B were small, substantially fresher water was present in the upper part of 3B (fig. 31 and 33). These distinct characteristics were observed only in the continuous data, and were not observed while fluid and flow logging were conducted.

Attempts to find linear correlations between the head difference between wells $2 \mathrm{~A}$ and $3 \mathrm{~B}$ and specific conductance at monitored depths at all three wells produced mixed results. Head difference was best correlated to specific conductance at well 3B $\left(\mathrm{R}^{2}=0.68\right.$ for the lower zone monitor and 0.54 for the upper zone monitor). Correlations between head difference and specific conductance were lower at wells $2 \mathrm{~A}$ and 201-M than at 3B, possibly reflecting the influence of numerous permeable zones and distance from actively pumping wells. For example, well 201-M has more than $700 \mathrm{ft}$ of open hole and is located west of the well field away from pumping centers. Contributions from flow zones of varying water quality may also compensate for head differences under specific pumping scenarios.

Individual permeable zones may compensate for pressure changes by contributing varying amounts of flow from specific zones with different water quality, without measurably affecting water levels. For example, data from one zone showed a time lag between observed water levels and specific conductance changes, whereas other zones experienced a change in either water level or specific conductance, but not both. Lag time between water-level changes and observed water-quality response can be explained as the time needed to allow various flow paths to equilibrate with different potentiometric conditions that induce ground-water movement. Pumping from wells open to multiple flow zones may induce water with relatively high or low specific conductance values to enter and exit along 

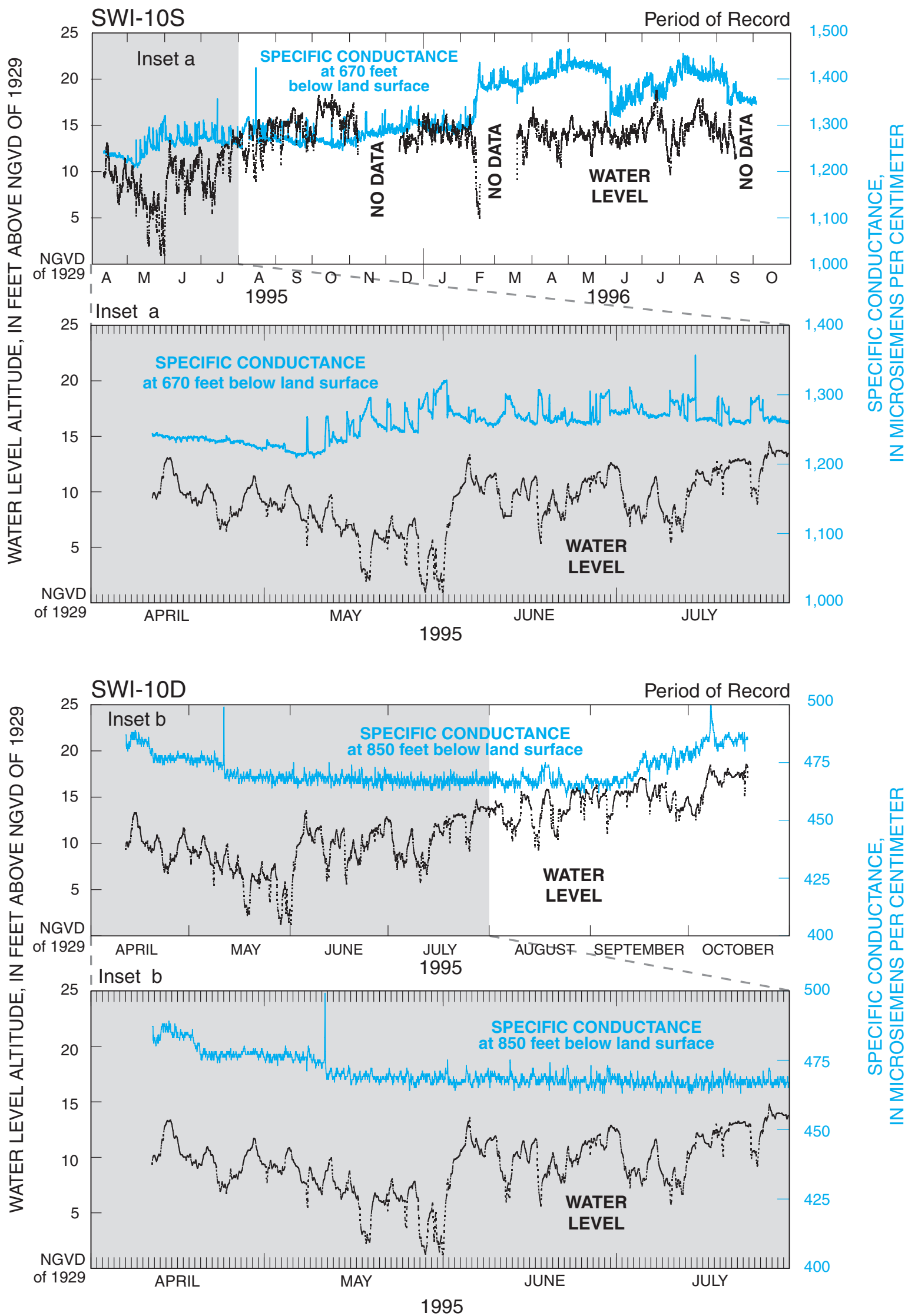

Figure 30. Water levels and specific conductance of water from fixed depths at wells SWI-10S and SWI-10D, April 1995-0ctober 1996. 


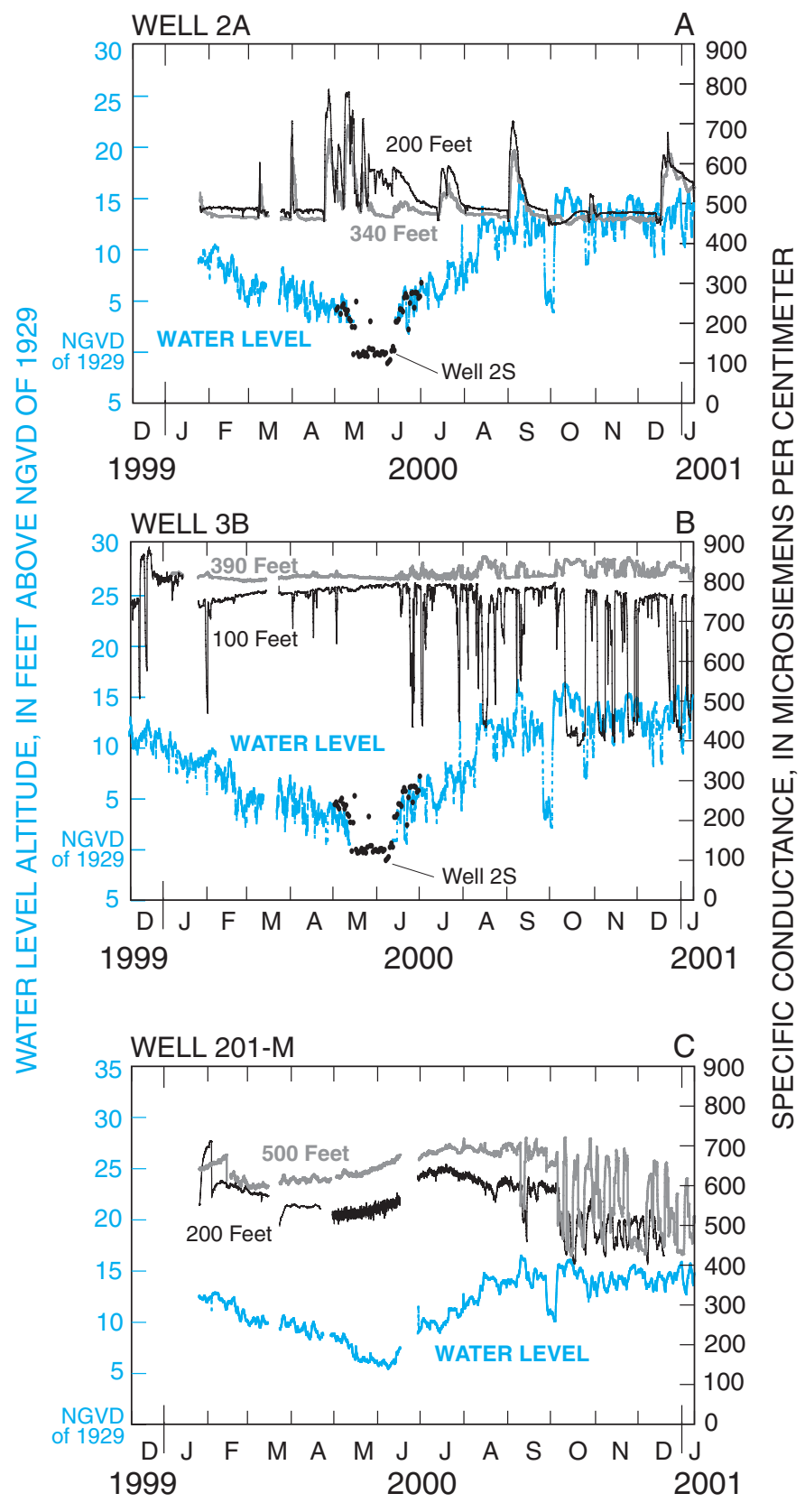

Breaks in lines indicate missing record

Figure 31. Water levels and specific conductance of water at selected depths at wells 2A, 3B, and 201-M at the Eldridge-Wilde well field, December 1999 -January 2001.

the permeable intervals. For example, in wells $2 \mathrm{~A}$ and $5 \mathrm{~N}$, water with high specific conductance enters one permeable zone and exits along another.

Although ground-water declines and pumpage correlated directly with some observed spatial and temporal patterns in specific conductance, there were periods of time when neither pumpage nor substantial head differences correlated with patterns observed in the specific conductance data. Because the observed relations and responses between pumping, water levels, and changes in specific conductance are complex and do not always follow a distinct pattern, it is likely that different pumping configurations induce different responses. Localized changes in ground-water movement within a heterogeneous aquifer, induced by pumping wells, may affect one well, but not another, because flow zones intersected by each well may be different.

\section{Chloride and Specific Conductance Variability in the Avon Park Producing Zone}

Within the study area, chloride concentrations and specific conductance varied over several orders of magnitude both spatially and temporally within the Avon Park producing zone. Chloride concentrations in water from wells with discrete openhole intervals, specific conductance logs, and continuous monitoring of specific conductance at fixed depths within selected wells open to the Avon Park producing zone were used to describe ground-water movement and mixing that could explain the observed variability. Primarily, vertical variations in waterquality data within the study area are related to the location of the well and proximity to the saltwater interface. In the study area, the depth to the saltwater interface decreases towards the west (fig. 22). Additionally, continuous data from fixed depths indicate that high specific-conductance ground water moves along specific flow zones and can affect the water quality of a borehole. Although water-quality changes appear to correspond to water-level changes, the specific conductance and percentage of total flow supplied by a flow zone from a specific depth can also affect the water quality of the borehole.

The highest specific conductance values within the study area were observed in wells with open-hole intervals within the Avon Park producing zone (580-780 ft below land surface). West of the EW well field at well NLKTP (open 758-780 ft below land surface), the specific conductance was 45,900 $\mu \mathrm{S} / \mathrm{cm}$. Specific conductance values greater than $20,000 \mu \mathrm{S} / \mathrm{cm}$ were identified in wells SWI-2D, SWI-6D, and SWI-7D, located 1 to 2 mi west of the well field (fig. 2), each with open intervals 600-750 ft below NGVD of 1929. Specific conductance at well SWI-4D, approximately $0.5 \mathrm{mi}$ west of the well field and open to approximately the same depth (710-775 ft below land surface), exceeded $6,000 \mu \mathrm{S} / \mathrm{cm}$. Nearby at well 201-M (open hole interval from 144-684 ft below land surface), specific conductance ranged from less than 500 to more than $800 \mu \mathrm{S} / \mathrm{cm}$, indicating that specific conductance values can be affected by movement of the nearby saltwater/freshwater interface. Within the well field, specific conductance values at SWI$10 \mathrm{~S}$ (open 650-700 below land surface) exceeded 1,000 $\mu \mathrm{S} / \mathrm{cm}$. At the same site (SWI-10D) (open 830-900 ft), specific conductance was lower, ranging from 400 to $900 \mu \mathrm{S} / \mathrm{cm}$.

Specific conductance values also fluctuated within the highly transmissive Avon Park producing zone. Specific conductance logs collected under ambient conditions at several wells with less than $200 \mathrm{ft}$ of open hole in the Avon Park producing zone (wells SWI-1S, SWI-1D, SWI-10S) showed 

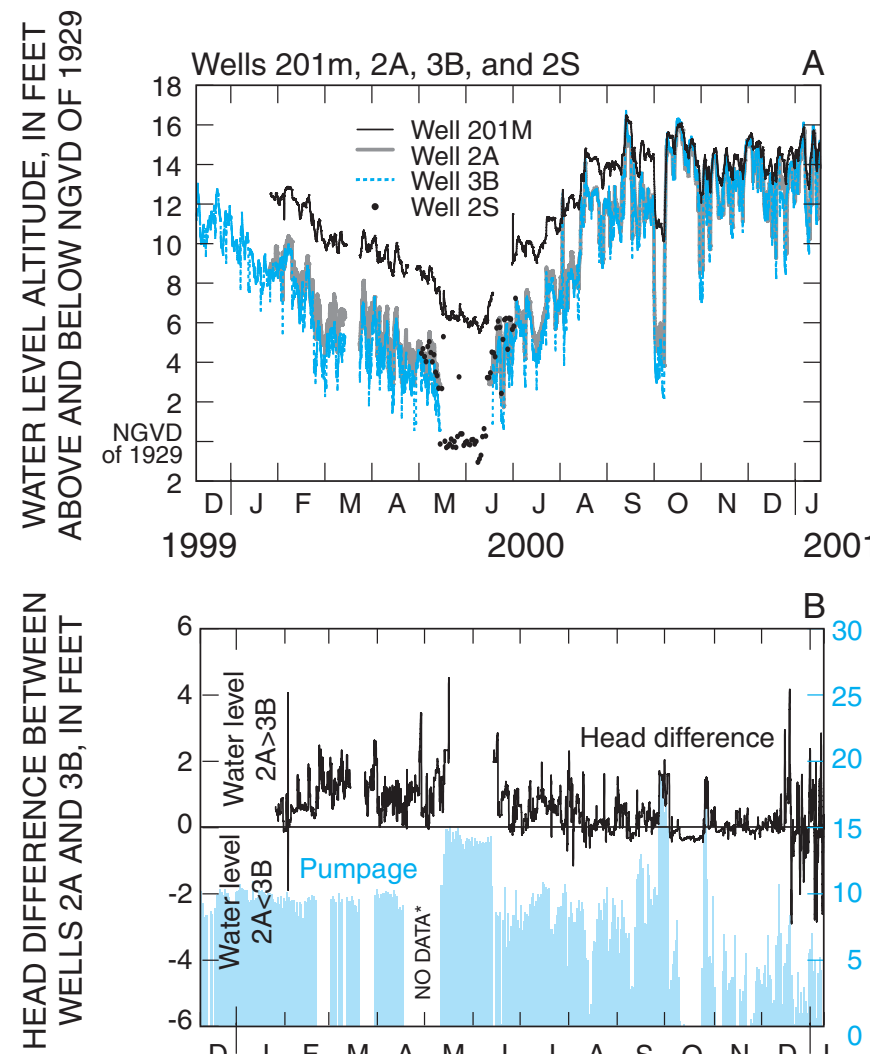

1999

2000

2001
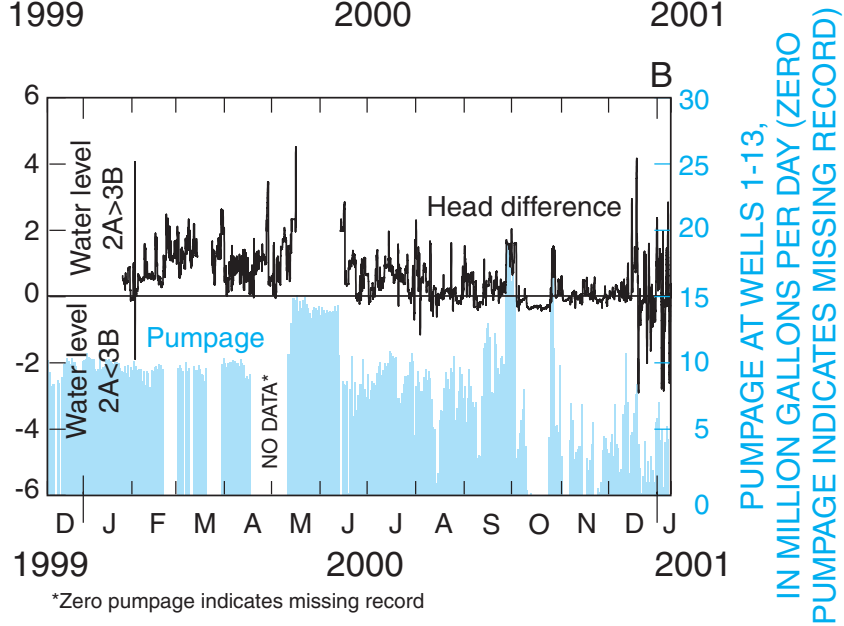

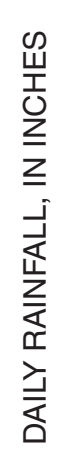

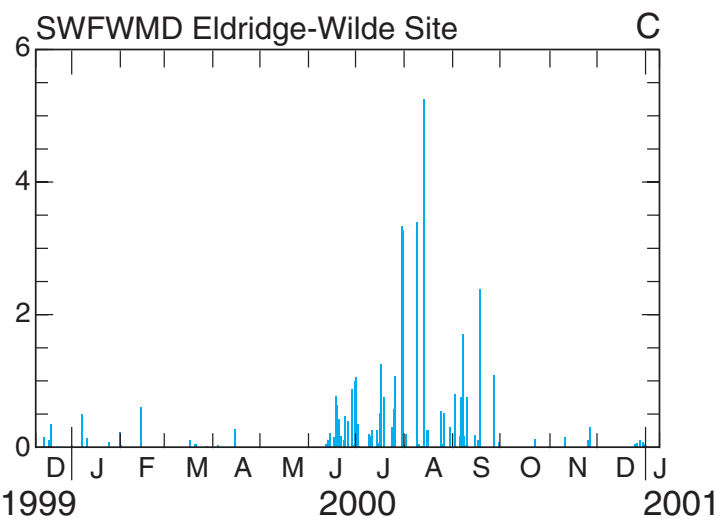

Breaks in lines indicate missing record except for figure 32c.

Figure 32. Water levels, pumpage, and head difference at selected wells, and rainfall at the Eldridge-Wilde well field, December 1999-January 2001.

both increases and decreases in specific conductance at intervals that correspond to the fracture zone identified in the acoustic televiewer logs (fig. 8). Specific conductance changes that can vary up to several thousand microsiemens per centimeter appear to be associated with discrete borehole intervals that may correspond to fractures within the Avon Park producing zone. The specific conductance logs of well SWI-1D indicate that fluid conductance under ambient conditions ranged from about 700 to about $2,000 \mu \mathrm{S} / \mathrm{cm}$ on three different dates in 1994 and 1995 (fig. 34). In May 1994, specific conductance generally decreased with depth to $615 \mathrm{ft}$ below NGVD of 1929, where a major decrease was observed (fig. 34). Specific conductance logs from March and August 1995, however, show a reversed trend. Similar reversals in specific conductance occurred at other sites, although to a lesser degree than those observed at SWI-1D; specific conductance profiles from wells 201-M, SWI-2S, SWI-5S and SWI-6S also indicate that specific borehole intervals are associated with water-quality changes. 


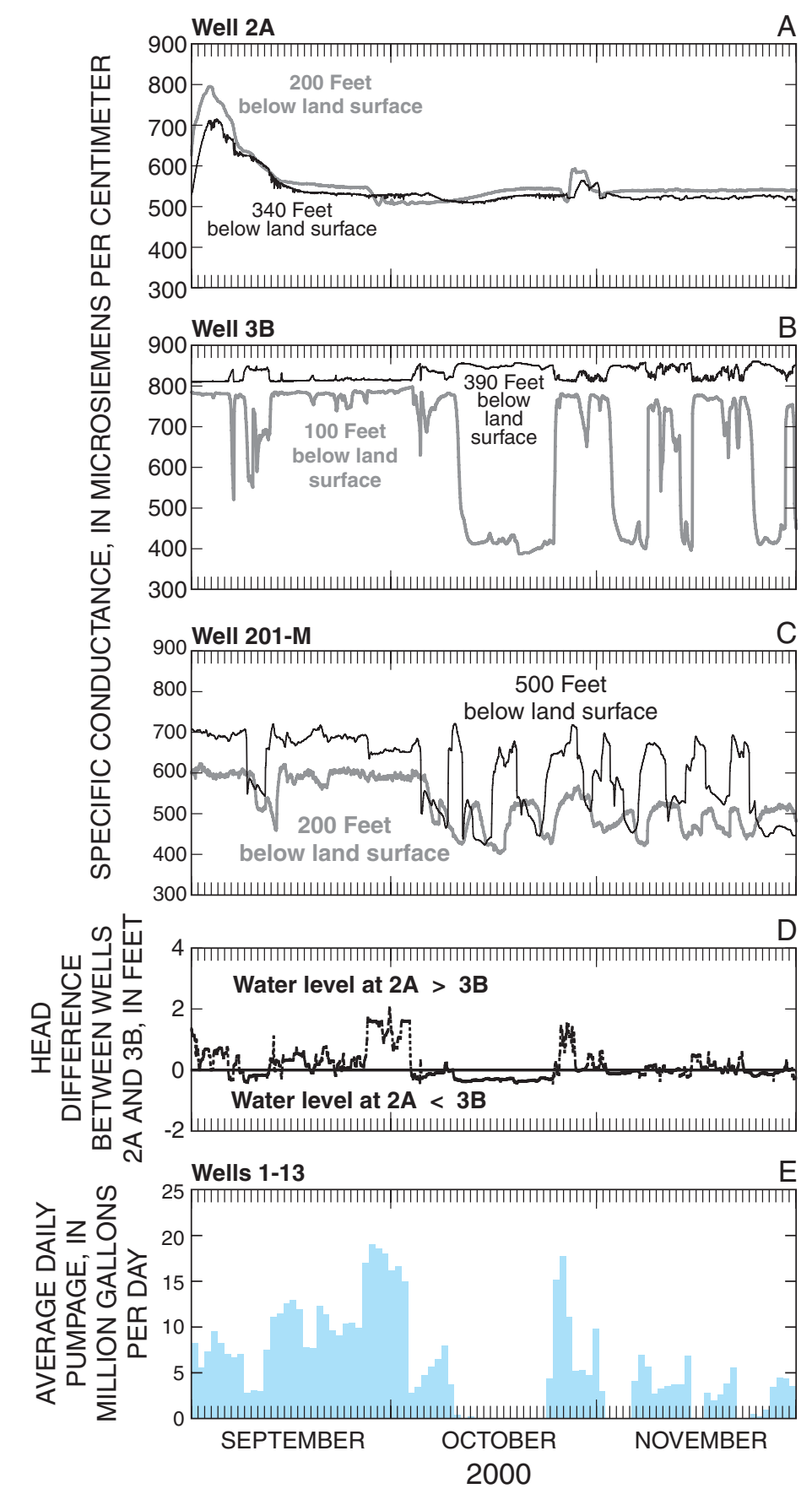

NOTE: Zero pumpage indicates missing record

Figure 33. Relation between ground-water pumpage, head differences, and continuous specific conductance at fixed depths in ground water at wells 2A, 3B, and 201-M, September-November 2000.

The presence of fractures within the Avon Park Formation appears to affect permeability and water quality but not waterlevel trends. Specific capacity, water levels, and specific conductance were compared at wells SWI-10S and SWI-10D, which are located about $30 \mathrm{ft}$ apart. Well SWI-10S penetrates the Avon Park producing zone, the same zone that provides water to nearby production wells. Acoustic televiewer data collected at SWI-10S indicate that numerous fractures were present at 600-650 ft below NGVD of 1929 in the monitored interval (fig. 8). The specific capacity determined for this interval was $525 \mathrm{gal} / \mathrm{min} / \mathrm{ft}$ (Nettles and Associates, Inc., 1990). Conversely, at SWI-10D, no distinct fractures were observed in the acoustic televiewer data at 830-900 $\mathrm{ft}$ below top of casing. The specific capacity determined for SWI-10D at this interval 


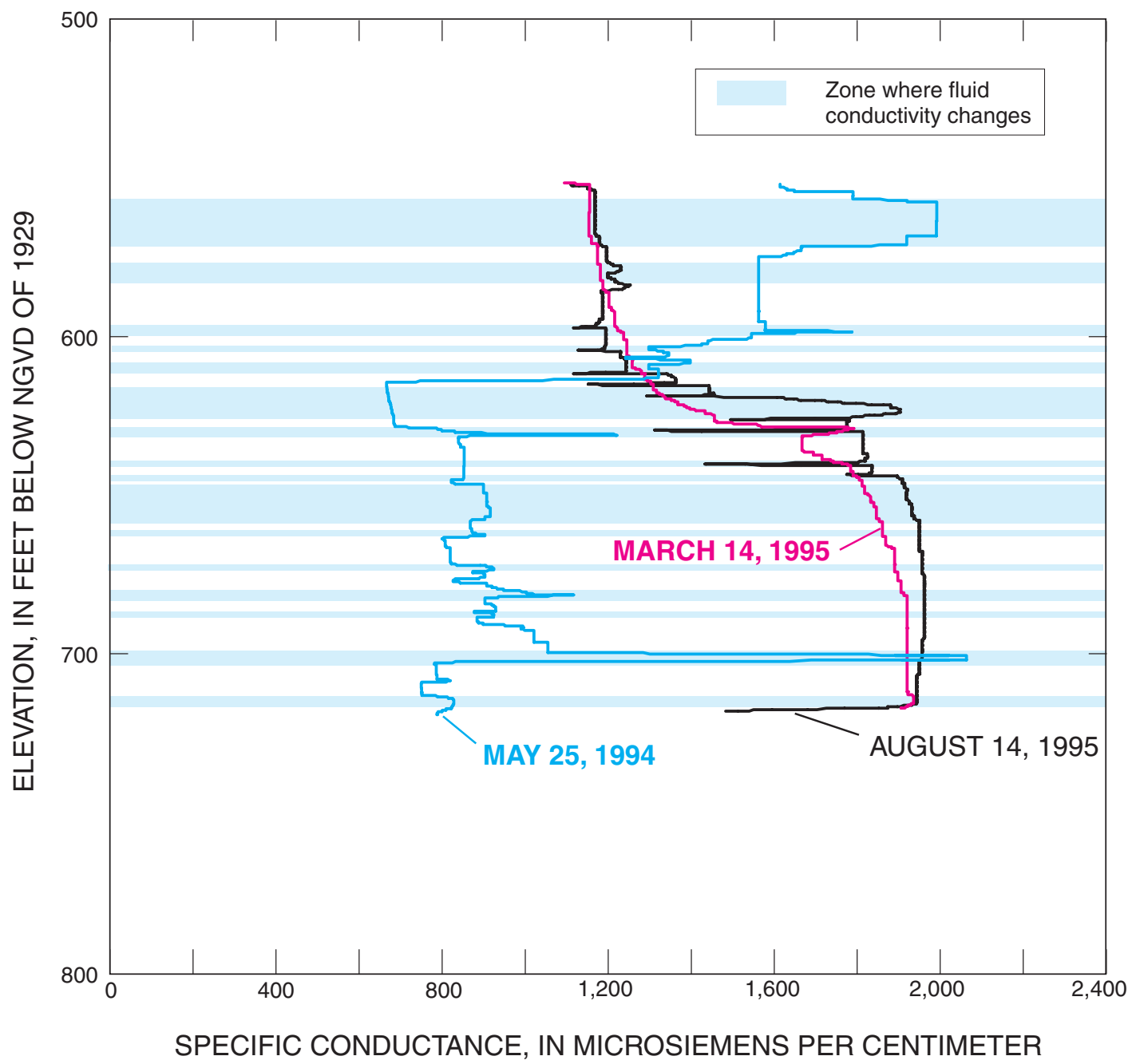

Figure 34. Selected fluid conductivity logs for well SWI-1D. Logs collected by Pinellas County, 1994-1995.

was $6 \mathrm{gal} / \mathrm{min} / \mathrm{ft}$, indicating the presence of a low permeability zone within the lower part of the UFA near the top of the MCU (Nettles and Associates, Inc., 1991c).

Although water-level changes at these two wells were nearly identical (fig. 30), changes in specific conductance in response to water-level changes were not. In well SWI-10S, specific conductance increased when water levels declined. In well SWI-10D, the change in specific conductance in response to water-level changes was minimal, with the exception of a few high-frequency fluctuations in water levels, like those observed at SWI-1D, which appeared to coincide with distinct sporadic increases in specific conductance. In contrast, within the high permeability zone at well SWI-10S, water-level changes were accompanied by nearly simultaneous changes in specific conductance (fig. 30).

Concurrent changes in water levels and specific conductance indicate that permeable zones within the Avon Park producing zone respond rapidly to water-level changes and appear to transmit water with high specific conductance along these permeable intervals. In some cases, a slight lag exists between the change in water level and the change in specific conductance. Pumping stresses at adjacent wells could induce ground-water movement along permeable zones intersected by the monitor wells. Both direct and lagged responses between water levels and specific conductance were observed at different periods at wells SWI-1S and SWI-10S, monitoring the Avon Park producing zone.

\section{Ground-Water Quality and Mixing}

In the study area, most ground water from the UFA is a calcium-bicarbonate-type water that has been enriched to varying degrees by mixing with seawater and calcium-sulfatetype water (Sprinkle, 1989; Maddox, 1992). Stiff diagrams plotted along an east-west geologic section from the coast to the well field show where calcium-bicarbonate water is predominant and where calcium-sulfate or sodium-chloride enrichment occurs at depth (fig. 35). Twenty-three wells within and outside of the 


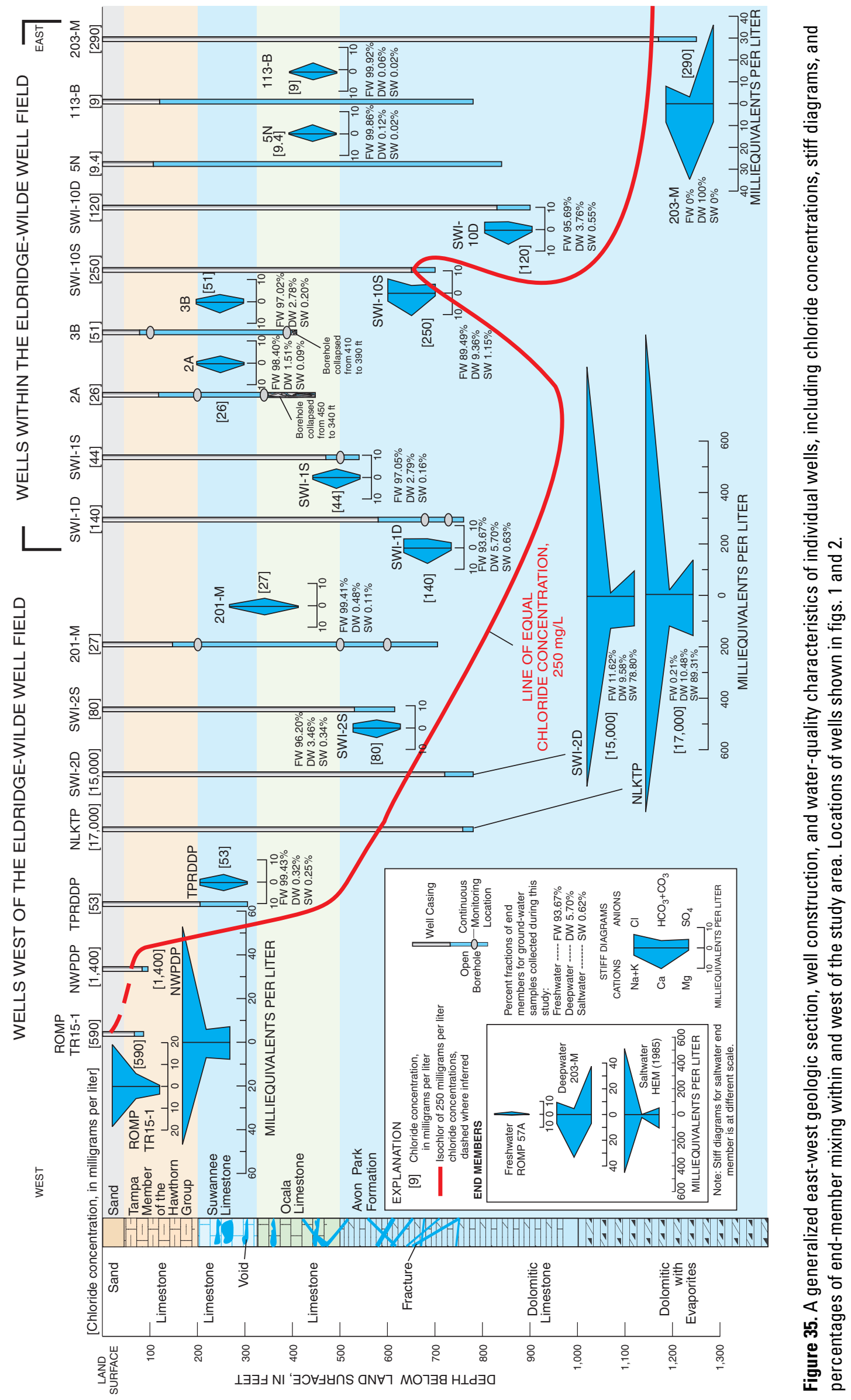




\section{Effects of Aquifer Heterogeneity on Ground-Water Flow and Chloride Concentrations, West-Central Florida}

well field were sampled during this study, including monitor wells constructed to discrete open-hole intervals and production wells with large open-hole intervals (fig. 1). Ionically enriched ground-water samples and a representative seawater composition (Hem, 1985) were used to characterize the water quality of "end-member" samples, which are defined as 100 percent calcium-bicarbonate, calcium-sulfate, and sodiumchloride type waters. Water-quality data are summarized in appendix B.

The location, length of open hole, and access to different depth zones of the UFA affect the overall composition of the water from production wells (fig. 35). Well 3B in the southwestern part of the well field is slightly deeper than the first supply wells constructed in the well field; open hole ranges from about 80 to $390 \mathrm{ft}$ below land surface, penetrating the Tampa/Suwannee producing zone. Well $5 \mathrm{~N}$ in the central part of the well field is typical of deeper well construction open to the Avon Park Formation; open hole ranges from about 107 to $863 \mathrm{ft}$ below land surface. Increases in chloride concentrations have been observed in both wells over time. When chloride concentrations were consistently greater than $80 \mathrm{mg} / \mathrm{L}$ at well 3B during the 1990s, the well was removed from production. Well 5N experienced increases in chloride concentrations above $20 \mathrm{mg} / \mathrm{L}$ beginning in 1986, then decreased to background levels by 1992. Concentrations of sodium, chloride, and sulfate are higher at well $3 \mathrm{~B}$ than at well $5 \mathrm{~N}$ even though well $3 \mathrm{~B}$ is shallower $(390 \mathrm{ft})$ than well $5 \mathrm{~N}(863 \mathrm{ft})$. Several factors could explain this difference. Well $3 \mathrm{~B}$ is located closer to the saltwater interface (where ground water has specific conductance greater than $10,000 \mu \mathrm{S} / \mathrm{cm}$ and chloride concentrations are in excess of $250 \mathrm{mg} / \mathrm{L}$ ), whereas well $5 \mathrm{~N}$ is located farther inland (figs. 1,2). Well 3B has a substantially shorter open-hole interval than well $5 \mathrm{~N}$, and the specific capacity at well $3 \mathrm{~B}$ is lower (40 gal/min/ft) than that at well $5 \mathrm{~N}(122 \mathrm{gal} / \mathrm{min} / \mathrm{ft})$. The specific conductance at well $3 \mathrm{~B}$ is dominated by a flow zone at $350 \mathrm{ft}$ below top of casing, associated with increased specific conductance (fig. 19). A major flow zone is present at a similar depth in well $5 \mathrm{~N}$, but the specific conductance is slightly lower and the overall higher specific capacity and length of open hole at well $5 \mathrm{~N}$ indicate that more freshwater flow enters well $5 \mathrm{~N}$ compared to well 3B (figs. 19, 20). Sodium, chloride, and sulfate concentrations in ground water increase as distance from the saltwater interface decreases (Sprinkle, 1989).

The chemical signature at each well represents a unique mixture of ground water depending on the depth of the well, the length of the open-hole interval, and water-quality characteristics of specific permeable zones. Analysis of a Piper diagram confirms that water from wells within the well field is a chemically variable mixture of the three water-quality types (fig. 36). Calculated mixing lines show end-member mixing between calcium-bicarbonate, calcium-sulfate, and sodium-chloride type waters (freshwater, deepwater, and saltwater, respectively). The calcium-bicarbonate water type end member is from ROMP 57A, an UFA well located east of the study area in Polk County, Florida ( fig. 1). Water from this well was selected to represent typical calcium-bicarbonate water having a low ionic concentration. Chloride concentration of water from ROMP 57A is low $(5.1 \mathrm{mg} / \mathrm{L})$, and is considered unaffected by influences of deepwater or the saltwater transition (mixing) zone. The calcium-sulfate water type end member is from well 203-M, which penetrates the MCU in the eastern part of the well field (fig. 2). The chloride and sulfate concentrations in water from 203-M are 290 and 1,800 mg/L, respectively, which is typical of upper MCU water and, therefore, considered representative of a deepwater source that would most likely influence the water chemistry within the study area. The sodium-chloride water type end member used to represent seawater within the Gulf of Mexico is the standard analysis of seawater as defined by Hem (1985).

Production wells and monitoring wells open to the production zones in the well field (5N, 202-M, 113-B, 201-M, 2A, 3B, SWI-1S) plot along the mixing line between the calcium-bicarbonate and calcium-sulfate water types (fig. 36). Deep wells within the well field that are open only to the Avon Park Formation plot closer to the 203-M end member, showing the influence of deepwater mixing and enrichment of sulfate. Coastal wells and deep wells (such as SWI-2D and SWI-6D), located to the south and west of the well field, plot near to the seawater composition. Water from well SWI-7D, west of the well field, is a mixture of sodium-chloride seawater and calcium-sulfate water. Deep wells open to the Avon Park Formation within the EW well field (SWI-1S, SWI-1D, SWI-2S, SWI-10S, SWI-10D) plot more towards the middle of the Piper diagram, indicating they are mixtures of seawater, deepwater, and freshwater.

The relation between the ratio of sulfate-to-chloride and sulfate concentration in ground water can help differentiate waters influenced primarily by deepwater from those influenced by seawater (fig. 37). Both seawater and deepwater mix with freshwater in the study area. Wells to the west of the well field are dominated by seawater mixing (SWI-2D, SWI-6D, SWI-7D, NWPDP, NLKTP). Shallow wells (2A and 3B) contain a mixture of all three water types but plot closer to the deepwater mixing line, indicating that these wells are influenced by ground water from the deeper zones of the Avon Park Formation.

The effect of proximity to the saltwater/freshwater interface on ground-water quality was examined by comparing the sulfate-to-chloride ratio to sulfate concentration at three monitor wells that penetrate the entire length of the UFA (fig. 37). Samples from wells 201-M, 202-M, and 113-B represent composite water quality similar to a deep production well with a large open-hole interval, and all have relatively low specific conductance because of the large open hole. Well 201-M is south and west of the well field, and well 202-M is north and west of the well field. Well 113-B is in the central part of the well field. Wells 201-M and 202-M are closer to the estimated location of the $10,000-\mu \mathrm{S} / \mathrm{cm}$ specific conductance line (saltwater interface) than well 113B (fig. 2). Wells 202-M and 113-B have similar concentrations of chloride and sulfate, but well 201-M has three times the sulfate and chloride concentrations found in wells 202-M and 113-B, indicating the influences of 


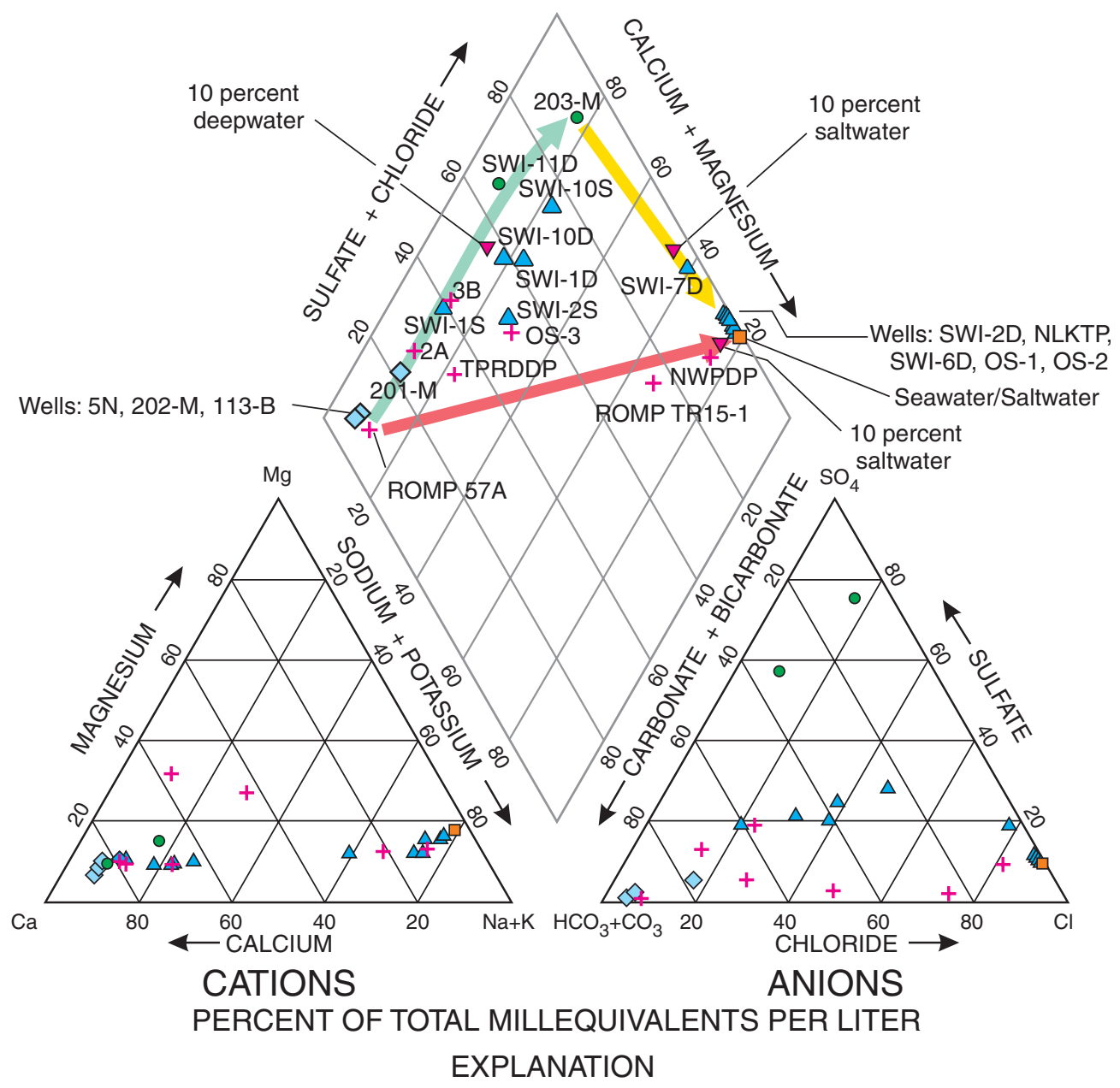

Water sample from:

+ Tampa Member of the Hawthorn Group, Suwannee Limestone, and Ocala Limestone

$\triangle$ Avon Park Formation

$\diamond$ Upper Floridan aquifer water sample (composite)

- Middle Confining Unit

$\square \quad$ Seawater (Hem, 1985)

$\nabla \quad 10$ percent mixing between end members

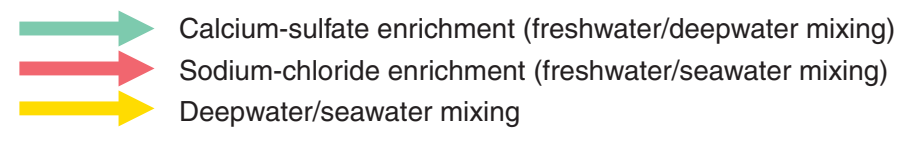

Freshwater end member-- ROMP 57A

Deepwater end member-- 203-M

Saltwater end member-- standard seawater composition

Figure 36. Ground-water mixing trends between end members and ground-water samples within the study area.

both calcium-sulfate and sodium-chloride water types associated with the high specific conductance ground water nearby (figs. 1, 37).

To quantitatively describe the amount of mixing, a threeway mixing model was used to calculate fractions of freshwater, deepwater, and saltwater. Mass-balance equations were derived using chloride and sulfate as conservative ions. Chloride was assumed to be conservative for this study, a standard assumption in water-quality calculations. Sulfate, which is less conservative, was used in the calculations to indicate mixing with deepwater that contains dissolved gypsum and other evaporite minerals. Sulfate is more reactive than chloride, and two possible reactions that could affect sulfate concentrations are: (1) sulfate reduction, which removes sulfate and produces sulfide, and (2) additional sources of sulfate other than the evaporites present in the lower part of the UFA. Sulfate reduction results in an underestimation of sulfate concentrations. The observed presence of sulfide in many of the wells indicates that sulfate reduction does occur, so the percentage of deepwater may be slightly underestimated. Sulfide concentrations, however, are low within the EW well field. The median value for sulfide as $\mathrm{H}_{2} \mathrm{~S}$ is $1 \mathrm{mg} / \mathrm{L}$, ranging from 0.06 to 2.95 , an order 


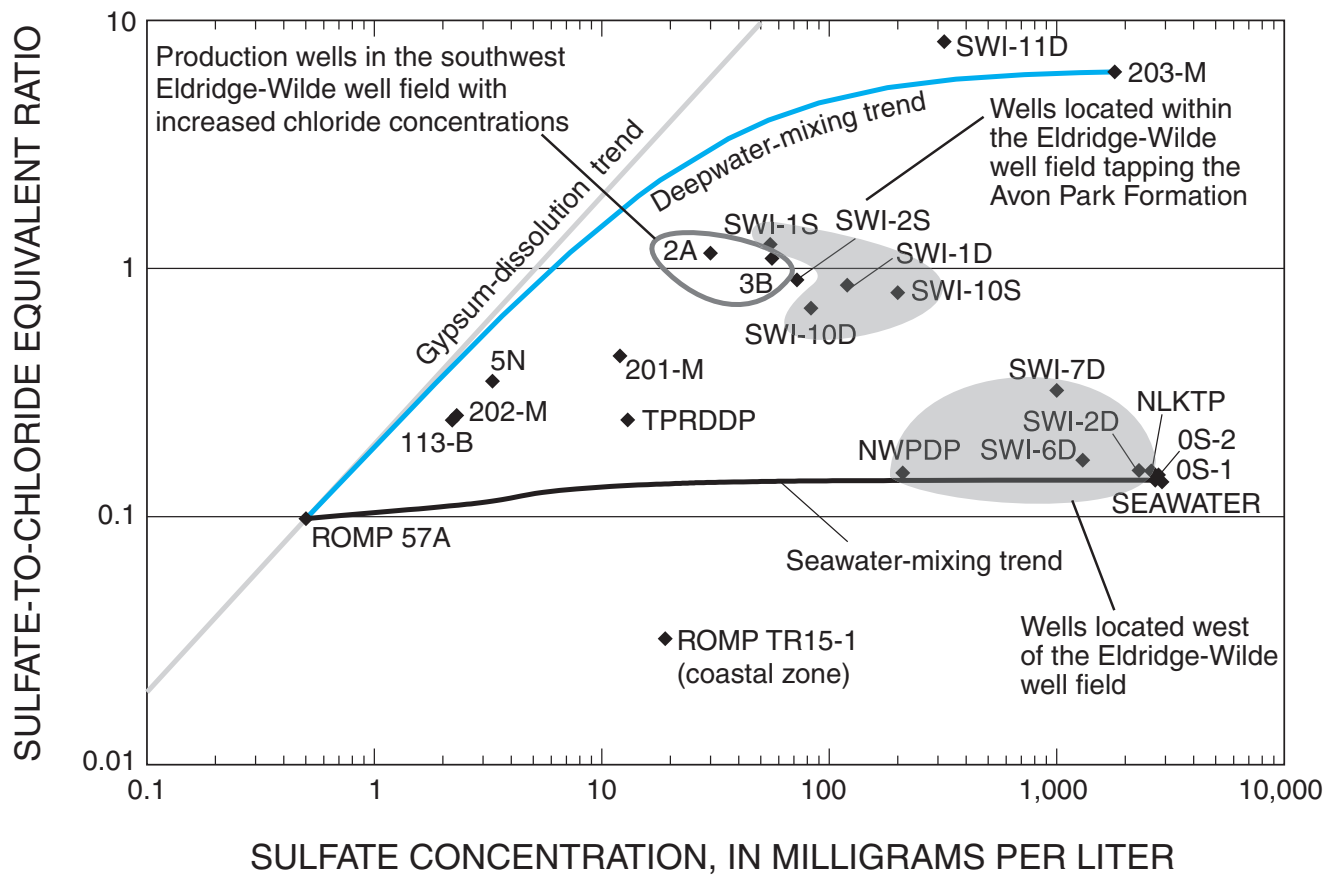

Figure 37. Relation of sulfate-to-chloride equivalent ratio to sulfate concentration in water from the Upper Floridan aquifer in and near the Eldridge-Wilde well field and end-member mixing lines. Locations of sampled wells shown in figs. 1 and 2. Well-construction and water-quality data are provided in appendixes $A$ and $B$, respectively, and in fig. 35.

of magnitude lower than sulfate concentrations (John Trout, Tampa Bay Water, written commun., 2001). Sulfide can be removed by pyrite precipitation, but the amount of pyrite precipitation probably is low based on geochemical modeling in other areas of the UFA (Plummer and others 1983; Sacks, 1996; Sacks and Tihansky, 1996; Plummer and Sprinkle, 2001). Therefore, the amount of reduced sulfur probably is low compared to sulfate. Based on the mineralogy of the UFA, the presence of additional major sources of sulfate is not likely (Sprinkle, 1989).

Assuming that all ground-water samples are a mixture of the three end members, each ground-water sample contains fractions of saltwater $\left(f_{\mathrm{sw}}\right)$, freshwater $\left(\mathrm{f}_{\mathrm{fw}}\right)$, and deepwater $\left(f_{d w}\right)$ :

$$
1=\left(f_{\mathrm{sw}}\right)+\left(f_{\mathrm{fw}}\right)+\left(\mathrm{f}_{\mathrm{dw}}\right) .
$$

The observed chloride and sulfate concentrations, in milligrams per liter, in a ground-water sample represent a mixture of fractions based on the chloride and sulfate concentrations of the end members:

$$
\begin{gathered}
\left(\mathrm{f}_{\mathrm{sw}}\right)\left(\left[\mathrm{Cl}^{-}\right]_{\mathrm{sw}}\right)+\left(\mathrm{f}_{\mathrm{fw}}\right)\left(\left[\mathrm{Cl}^{-}\right]_{\mathrm{fw}}\right)+\left(\mathrm{f}_{\mathrm{dw}}\right)\left(\left[\mathrm{Cl}^{-}\right]_{\mathrm{dw}}\right)= \\
{\left[\mathrm{Cl}^{-}\right]_{\text {observed gw sample }} \text {, and }} \\
\left(\mathrm{f}_{\mathrm{sw}}\right)\left(\left[\mathrm{SO}_{4}{ }^{2-}\right]_{\mathrm{sw}}\right)+\left(\mathrm{f}_{\mathrm{fw}}\right)\left(\left[\mathrm{SO}_{4}{ }^{2-}\right]_{\mathrm{fw}}\right)+\left(\mathrm{f}_{\mathrm{dw}}\right)\left(\left[\mathrm{SO}_{4}{ }^{2-}\right]_{\mathrm{dw}}\right)= \\
{\left[\mathrm{SO}_{4}{ }^{2-}\right]_{\text {observed gw sample. }}}
\end{gathered}
$$

Percentages of freshwater, deepwater, and saltwater calculated for samples based on the mixing calculations are shown in table 3 and figure 35. A sensitivity analysis based on 5-percent variability of chloride and sulfate concentrations indicated that percentage error for calculated mixing percentages ranged from 0 to 0.16 percent. Samples from wells with large open-hole intervals were used to compare with historical trends at production wells, because these mixtures represent generalized waterquality characteristics of the entire aquifer. Samples from wells with discrete open-hole intervals were used to describe specific water-quality characteristics of distinct hydrogeologic units, and are better for describing ground-water mixing reactions occurring in the area.

\section{Freshwater Mixing}

The freshwater fractions for ground-water samples, excluding the end members, averaged about 80 percent and ranged from 0.21 to 99.92 percent (table 3 ). Within the well field, ground water with the greatest percentage of freshwater (greater than 95 percent) came from wells penetrating the Tampa/Suwannee producing zone and from wells with large intervals open to the entire UFA. Ground water that was 90 to 95 percent freshwater came from wells of varied depth and open-hole interval, and was mixed with 3 to 6 percent deepwater. The freshwater fraction ranged from 0.21 (NLKTP) to 89 percent (SWI-10S) for ground water with less than 90 percent 


\section{Deepwater Mixing}

Table 3. Percentages of mixing end members calculated for selected ground-water samples within the study area using the ionic concentrations of ground water from ROMP 57A, 203-M, and modern seawater, as freshwater, deepwater, and saltwater end members, respectively.

[bls, below land surface]

\begin{tabular}{lcccc}
\hline \multicolumn{1}{c}{ Site name } & $\begin{array}{c}\text { Open hole } \\
\text { (feet bls) }\end{array}$ & $\begin{array}{c}\text { Percent } \\
\text { freshwater }\end{array}$ & $\begin{array}{c}\text { Percent } \\
\text { deepwater }\end{array}$ & $\begin{array}{c}\text { Percent } \\
\text { saltwater }\end{array}$ \\
\hline 113-B & $120-780$ & 99.92 & 0.06 & 0.02 \\
202-M & $132-780$ & 99.91 & 0.07 & 0.02 \\
5N & $106-863$ & 99.86 & 0.12 & 0.02 \\
\hline TPRDDP & $205-305$ & 99.43 & 0.32 & 0.25 \\
201-M & $144-684$ & 99.41 & 0.48 & 0.11 \\
2A & $113-340^{\mathrm{a}}$ & 98.40 & 1.51 & 0.09 \\
\hline SWI-1S & $470-540$ & 97.05 & 2.79 & 0.16 \\
3B & $78-390^{\mathrm{b}}$ & 97.02 & 2.78 & 0.20 \\
SWI-2S & $530-630$ & 96.20 & 3.46 & 0.34 \\
\hline SWI-10D & $830-900$ & 95.69 & 3.76 & 0.55 \\
SWI-1D & $580-760$ & 93.67 & 5.70 & 0.63 \\
SWI-10S & $650-700$ & 89.49 & 9.36 & 1.15 \\
\hline SWI-11D & $810-899$ & 82.20 & 17.89 & 0.00 \\
SWI-7D & $680-740$ & 52.37 & 31.82 & 15.81 \\
SWI-6D & $640-720$ & 47.96 & 11.71 & 40.33 \\
\hline SWI-2D & $720-780$ & 11.62 & 9.58 & 78.80 \\
NLKTP & $758-780$ & 0.21 & 10.48 & 89.31 \\
\hline Average & & 80.02 & 6.58 & 13.39 \\
Maximum & & 99.92 & 31.82 & 89.31 \\
Minimum & & 0.21 & 0.06 & 0.00 \\
\hline End members: & & & & \\
\multicolumn{1}{c}{ EW 203-M } & & 0 & 100 & 0 \\
\multicolumn{1}{c}{ Seawater } & & 100 & 0 & 100 \\
\hline ROMP 57A & & & 0 & 0 \\
\hline
\end{tabular}

${ }^{\mathrm{a} O r i g i n a l ~ d e p t h} 450$ feet; ${ }^{\mathrm{b}}$ Original depth 410 feet; ${ }^{\mathrm{c}} \mathrm{Hem}$ (1985).

freshwater. The deepwater and saltwater fractions of water from these two wells varied considerably. Water from well NLKTP tapping the Avon Park producing zone west of the well field and within the saltwater interface, contained the lowest freshwater fraction - approximately 10 percent deepwater and 89 percent saltwater. Other wells west of the well field tapping the Avon Park producing zone contained low freshwater fractions; wells SWI-6D and SWI-7D contained 48 and 52 percent freshwater, respectively. Deepwater and saltwater fractions from these two wells were substantially different. Water from well SWI-6D contained 40 percent saltwater and 12 percent deepwater, whereas water from well SWI-7D contained about 16 percent saltwater and 32 percent deepwater.
Most wells had ground water with higher sulfate concentrations than could be explained by the mixing of freshwater and saltwater, indicating deep aquifer gypsum dissolution as an additional source (Rye and others, 1981; Sacks, 1996; Sacks and Tihansky, 1996). Deepwater fractions for all wells sampled ranged from 0 to 32 percent (table 3 ). Wells with the lowest percentage of deepwater also had the longest open-hole intervals. Water from five wells, 5N, 113-B, 202-M, 201-M, and TPRDDP showed little to no influence of sulfate-enriched water, having deepwater fractions less than or equal to 0.5 percent (table 3, figs. 35, 36). The first four of these wells have over $500 \mathrm{ft}$ of open hole and fresh flow zones may substantially dilute the deepwater component. Well TPRDDP (fig. 1), west of the well field, penetrates the Tampa/Suwannee producing zone and has only $100 \mathrm{ft}$ of open hole. The deepwater fraction of this well was 0.32 percent.

The presence of increased deepwater fractions in shallow aquifer zones within the well field indicates upward migration of deepwater into shallow producing zones. Ground water from wells within the well field having less than 1 percent saltwater had deepwater fractions ranging from 2 to 6 percent (table 3 ). Deepwater fractions within shallow aquifer zones (less than $400 \mathrm{ft}$ deep) within the well field (wells $2 \mathrm{~A}$ and $3 \mathrm{~B}$ ) are more than four times as high as the same zone outside the well field at well TPRDDP. The deepwater enrichment occurred primarily in areas where the potentiometric surface was lowered by ground-water withdrawals.

The largest deepwater fractions (greater than 15 percent) were present at monitor wells outside the well field with less than $100 \mathrm{ft}$ of open hole penetrating the Avon Park Formation (table 3). Water from well SWI-11D is from the less permeable zone of the Avon Park Formation (810-899 ft below land surface) and is a mixture of freshwater (82 percent) and deepwater (18 percent), with no saltwater component. Farther west, well SWI-7D (fig. 2), also open to the Avon Park producing zone (680-740 ft below land surface), has greater ionic concentrations and is a mixture of deepwater (32 percent), saltwater (16 percent) and freshwater (52 percent). At these concentrations, the freshwater fraction has negligible influence on water quality, and on a Piper diagram, the ionic mixture falls along a mixing line between seawater and deepwater (fig. 36). Both of these wells are located north and west of the major pumping area (figs. 1, 26).

\section{Saltwater Mixing}

The saltwater interface, as defined by specific conductance greater than $10,000 \mu \mathrm{S} / \mathrm{cm}$, has been delineated about one $1 \mathrm{mi}$ west of the well field in the Avon Park producing zone at 680$780 \mathrm{ft}$ below land surface (figs. 1, 2, 26). The saltwater fraction ranged from 0 to 89 percent of the ground-water composition for all wells sampled (table 3). Ground-water samples with the highest percentages of saltwater came from wells that were 
open to less than $100 \mathrm{ft}$ of aquifer in the Avon Park producing zone and were a mile or more west and southwest of the well field. The highest percentage of saltwater ( 89 percent) was present south and west of the EW well field at well NLKTP, which taps the Avon Park producing zone (758-780 ft below land surface). Other ground-water samples with saltwater fractions greater than 15 percent were from wells SWI-2D, SWI-6D, and SWI-7D, which also tap the Avon Park producing zone. The saltwater fractions in these wells were 79, 40, and 16 percent, respectively (table 3 ).

Ground water from monitoring wells in or close to the EW well field generally contained less than 1 percent saltwater. Only a few wells (SWI-1S, SWI-1D, and SWI-10S) within the well field are constructed to monitor discrete intervals within the Avon Park producing zone where higher percentages of saltwater may be present (figs. 26, 35). Below the Avon Park producing zone (well SWI-10D), ground water is a mixture of 3.8 percent deepwater, 0.6 percent saltwater, and 96 percent freshwater. Wells SWI-1S, SWI-1D, and SWI-10S penetrate the highly permeable producing zone and have deepwater fractions ranging from 3 to 9 percent and saltwater fractions ranging from 0.16 to 1.15 percent. Based on these wells, both deepwater and saltwater fractions increase with depth and towards the center of the well field.

\section{Combined Effects of Deepwater and Saltwater Mixing}

Although saltwater mixing is minimal in the well field, small percentages of saltwater can affect the potability of the ground water. For example, a mixture of 1.3 percent saltwater and 98.7 percent freshwater results in a chloride concentration of $250 \mathrm{mg} / \mathrm{L}$ (the drinking-water standard). Thus, even small amounts of saltwater mixing are important to the ground-water quality. Because of high sulfate concentrations, a larger fraction of deepwater (10-15 percent) also would render drinking water nonpotable. At the EW well field, both deepwater and saltwater mixing occur. The highest fractions of saltwater and deepwater were found within the Avon Park producing zone in areas where the potentiometric surface was the lowest.

Less than $400 \mathrm{ft}$ below land surface, chloride and sulfate concentrations present in shallow wells in and near the well field are associated with deepwater and saltwater mixing. In the Tampa/Suwannee producing zone, chloride concentrations are less than 0.5 percent of the concentration in seawater. Groundwater samples from the Tampa/Suwannee producing zone west of the well field (TPRDDP), plot more closely along the seawater mixing line than ground-water samples from wells within the well field (fig. 37), indicating a dominant seawater source for the chloride concentrations outside the well field. Within the same producing zone, however, in the southwestern part of the well field (wells 2A and 3B), ground-water samples plot closer to the deepwater mixing line, with mass-balance calculations indicating that elevated chloride concentrations are from a deepwater source. Increased sulfate concentrations, especially in wells within the well field, indicate that there is a deep ground-water source of chloride and sulfate. The deepwater component within the well field is four times greater than that observed to the west within the Tampa/Suwannee producing zone, although overall chloride concentrations are similar. In wells that tap both the Tampa/Suwannee producing zone and the Ocala semiconfining unit that are located toward the center of the well field, the deepwater fraction doubles that found in wells outside the well field in the same zone.

Chloride concentrations are in part associated with mixing that occurs in the transition zone between saltwater and freshwater. The combined effects of deepwater and saltwater mixing on chloride and specific conductance for discrete sampling depths are shown in figure 38. Historical water-quality data from Pinellas County and the USGS follow two main trends. Water samples from the southwestern part of the well field within the Avon Park producing zone (shown in pink) plot parallel to the calculated chloride/specific conductance curve (Ron Miller, U.S. Geological Survey, written commun., 2000), indicating that saltwater mixing is the predominant factor affecting ground-water quality. The consistent offset above the curve is attributed to minor amounts of sulfate enrichment from deepwater mixing, which causes higher specific conductance than can be explained by increasing chloride from saltwater mixing alone. Water samples from the UFA at depths above and below the Avon Park producing zone (generally less than $550 \mathrm{ft}$ or greater than $760 \mathrm{ft}$ below land surface) showed some enrichment of sulfate, but relatively low (less than $100 \mathrm{mg} / \mathrm{L}$ ) chloride concentrations (fig. 38). Water quality in these wells (shown in blue) is predominantly affected by deepwater mixing. Water with both high specific conductance and chloride concentrations from depths 1,100 to 1,240 ft below land surface (MCU) also are affected by deepwater mixing. Shallow wells $2 \mathrm{~A}$ and 3B show effects of both saltwater and deepwater mixing. Deepwater mixing occurs to varying degrees throughout the groundwater system but saltwater mixing occurs predominantly within the Avon Park producing zone.

The relative permeability of hydrogeologic units and distance from deepwater and saltwater sources (relative sulfate and chloride concentrations) control where and to what extent ground-water mixing occurs. The influence of a deepwater source appears to affect most wells throughout the southwestern part of the well field (fig. 35). Sulfate concentrations increase with depth as the proximity to a deepwater source decreases. Discrete flow zones, however, and periodic increases in specific conductance in relatively shallow wells, such as wells $2 \mathrm{~A}$ and 3B (figs. 31 and 33), indicate that deepwater may be migrating along geologic features that are associated with increased permeability. Similar relations exist within the Avon Park producing zone. Increases in chloride concentrations related to a saltwater source occur in wells that are open to the Avon Park producing zone south and west of the well field. Moderately saline water, about a mile south and west of the well field, appears to move preferentially inland along the fractured and highly permeable Avon Park producing zone. Similar preferential ground-water movement has been simulated along zones of high transmissivity in deep-well injection flow studies within the Avon Park Formation in Pinellas County (Hutchinson and 


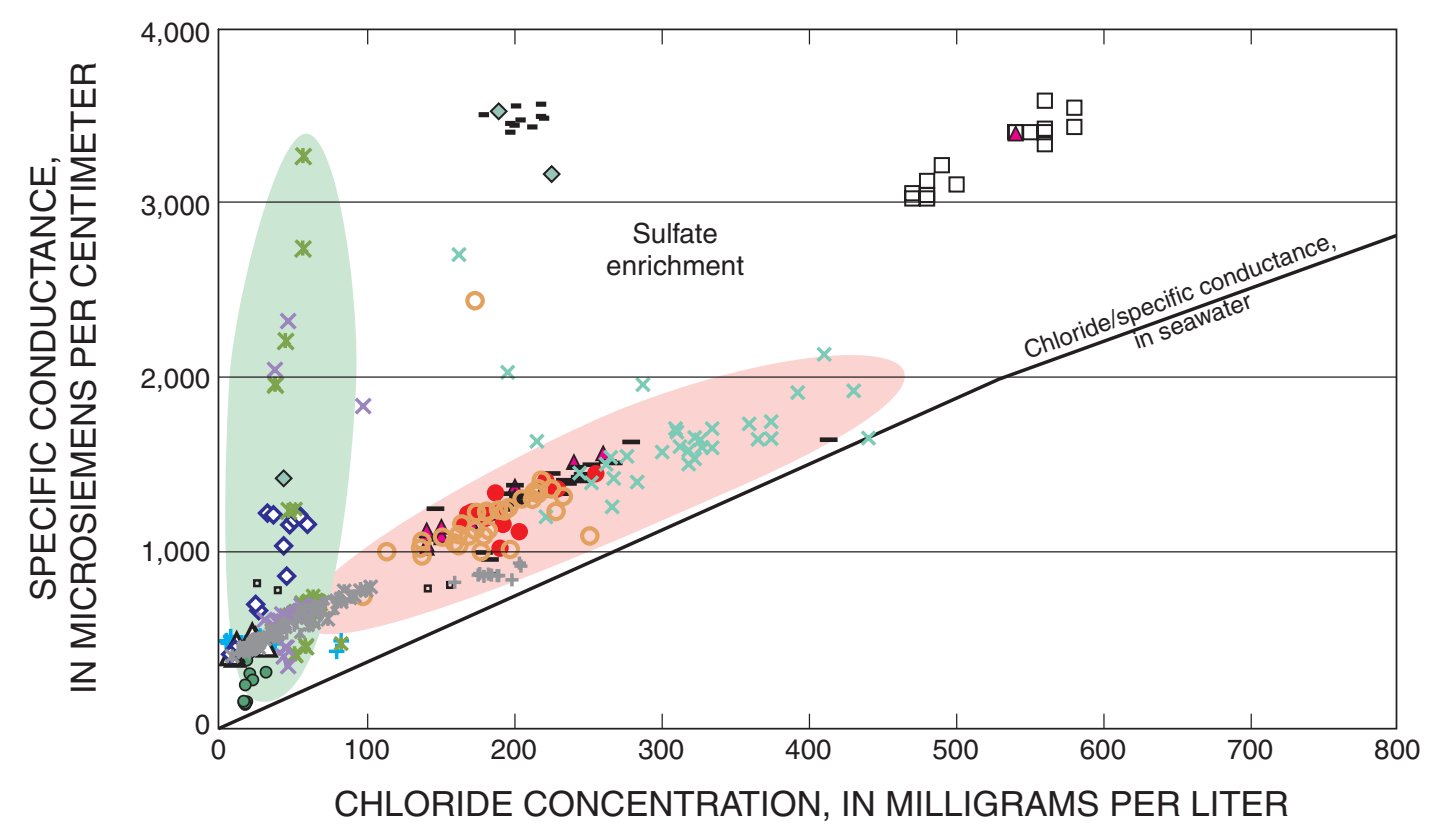

EXPLANATION

- SWI-10D, 870 feet Well symbol, well name, sampling depth in feet below land surface

Relation between chloride and specific conductance, in seawater

(Ron Miller, U.S. Geological Survey, written commun., 2000)

\begin{tabular}{cl} 
& $\begin{array}{l}\text { Ground-water quality affected } \\
\text { primarily by saltwater mixing }\end{array}$ \\
+ & SWI-10S,630-640 feet \\
- & SWI-10S, 660-670 feet \\
$\bar{\Delta}$ & SWI-10S, 680 feet \\
\hline & EWMW3A, 685 feet \\
$\times$ & SWI-1D, 620-700 feet \\
& SWI-1D, 700-760 feet
\end{tabular}

\begin{tabular}{cl} 
& $\begin{array}{l}\text { Ground-water quality affected } \\
\text { primarily by deepwater mixing }\end{array}$ \\
$\times$ & SWI-1S, 500 feet \\
$*$ & SWI-1S, 520-540 feet \\
$\Delta$ & SWI-11D, 820-870 feet \\
$\diamond$ & SWI-11D, 870-890 feet \\
+ & SWI-10D, 870 feet \\
0 & EWMW3A, 890 feet \\
$\square$ & EWMW3A, 1,090 feet \\
\hline & 203-M, 1,230 feet \\
$\diamond$ & 203-M, 1,240 feet
\end{tabular}

Shallow wells that exhibit effects of both saltwater and deepwater mixing

* 2A, 320 feet

- $3 \mathrm{~B}, 380$ feet

SWI-1D, 620-700 feet

Figure 38. Relation between chloride concentration and specific conductance for ground-water samples obtained at specific depth intervals. Well locations shown in fig. 2.

others, 1993) and chloride migration has been documented to occur along fractures within the Floridan aquifer system in northeastern Florida and southeastern Georgia (Maslia and Prowell, 1990; Phelps and Spechler, 1997).

The localized existence of low chloride concentrations between the MCU and the Avon Park highly transmissive zone indicates saltwater moves inland preferentially along fractures within the same highly transmissive zone in which ground water is withdrawn for supplies. Ground water from the deepest part of the UFA (from wells penetrating depths greater than $870 \mathrm{ft}$ deep) had chloride concentrations ranging from less than 100 to more than $500 \mathrm{mg} / \mathrm{L}$, with sulfate concentrations generally greater than $200 \mathrm{mg} / \mathrm{L}$ (fig. 38). These concentrations reflect the low transmissivity of the deep zone when compared to the highly productive Avon Park producing zone above it.

\section{Isotopic Evidence of Ground-Water Mixing}

The relation between $\delta^{18} \mathrm{O}$ and $\delta \mathrm{D}$ also can be used to identify sources of water. Isotopically light waters generally indicate recent recharge, whereas heavier signatures indicate that the waters have either been enriched by evaporative processes, are older waters that recharged under different climatic conditions, or are influenced by seawater. Within the study area, ground water with less than 90 percent freshwater (table 3) plots on the seawater mixing line, indicating that saltwater mixing is the likely source for elevated chloride concentrations in these wells (fig. 39). The $\delta^{18} \mathrm{O}$ ratios in waters having greater than 90 percent freshwater, however, are highly variable. Comparison of $\delta^{18} \mathrm{O}$ and $\delta \mathrm{D}$ data for fresh ground waters indicates that evaporation prior to recharge could cause the 


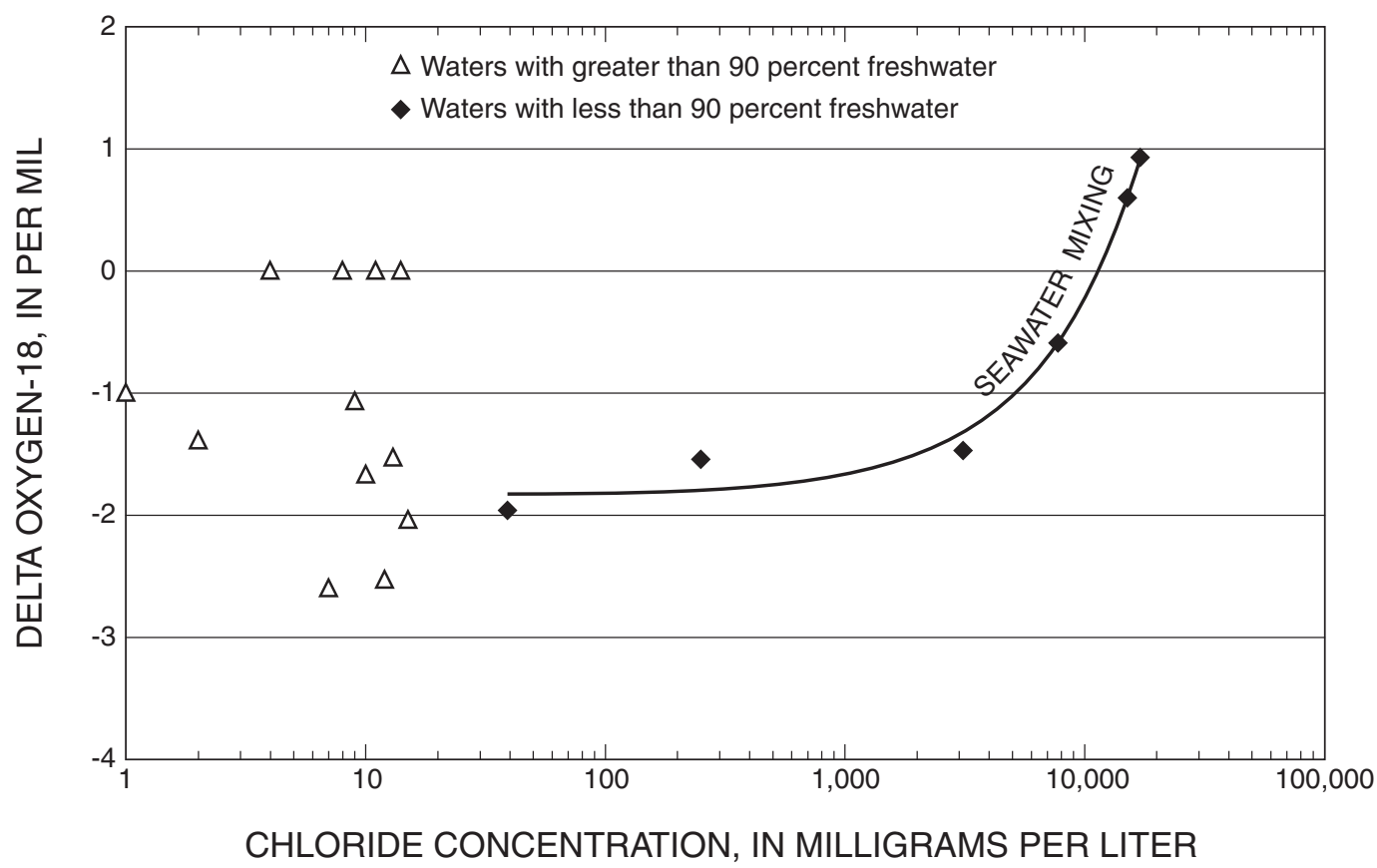

Figure 39. Relation between chloride concentration and delta oxygen-18 for selected Upper Floridan aquifer water samples.

observed isotopic enrichment of $\delta^{18} \mathrm{O}$ and $\delta \mathrm{D}$, rather than saltwater mixing. Ground-water recharge within the study area occurs by way of mantled sinkholes and karst features that underlie numerous shallow ponds and wetlands. As evaporative processes occur in the wetlands and ponds, recharge water entering the ground-water system has an evaporative isotopic signature. The point sources of recharge to the ground water and preferential flow paths likely contribute to poor regional mixing and could explain the variability in the observed $\delta^{18} \mathrm{O}$ and $\delta \mathrm{D}$ ratios. In general, when chloride concentrations are less than $1,000 \mathrm{mg} / \mathrm{L}, \delta^{18} \mathrm{O}$ is not a good tracer for sources of salinity (fig. 39).

Strontium isotopes were analyzed in water from selected wells and were compared to chloride concentrations and strontium signatures for geologic units (Hess and others, 1986). Most data plotted in a range indicating Oligocene-age seawater even though the water was from wells open to the Avon Park Formation, which is Eocene age (fig. 40a). This age discrepancy may be a result of diagenetic changes that have affected the composition of strontium in the aquifer materials or a result of mixing with water having a younger strontium source, such as ground water from the Suwannee Limestone or modern seawater. Wells open to multiple flow zones receive a mixture of ground water that has been in contact with geologic formations of younger ages. The Avon Park Formation is a dolomite unit, and deep mineralized ground water likely has undergone substantial diagenetic changes. Strontium is not conservative, and multiple sources related to carbonate dissolution and precipitation reactions could alter the strontium isotope ratio in rocks such as dolomites. Sacks and Tihansky (1996) found that ground water in southwestern Florida had ${ }^{87} \mathrm{Sr} /{ }^{86} \mathrm{Sr}$ isotope ratios indicating Oligocene age, although the aquifer materials were of Eocene age. The Oligocene-age seawater signature resulted from dissolved strontium derived from Eocene-age rocks mixing with strontium derived from younger seawater that was introduced into the aquifer. The mixture of isotopically heavier modern seawater with the lighter signature of Eoceneage rocks could result in an isotopic signature indicating an Oligocene age.

The strontium isotopic signature in ground water sampled during this study ranged from Miocene to Eocene regardless of the chloride concentrations (fig. 40a). Wells with large openhole intervals showed a greater range in strontium isotopic signatures, indicating that multiple flow zones contribute to a mixed strontium value. Deepwater is enriched in strontium from dissolution of evaporates in the Eocene-age MCU, and waters with high percentages of deepwater (greater than 10 percent) had ${ }^{87} \mathrm{Sr} /{ }^{86} \mathrm{Sr}$ ratios closest to those of Eocene age (fig. 40b). Samples from two shallow coastal wells, ROMP TR15-1 and NWPDP (fig. 40b), have ${ }^{87} \mathrm{Sr} /{ }^{86} \mathrm{Sr}$ ratios close to modern seawater, indicating that nearby seawater has interacted with the aquifer at these sites. Most wells, especially those in the southwestern part of the well field, have ${ }^{87} \mathrm{Sr} /{ }^{86} \mathrm{Sr}$ ratios that indicate mixing of both saltwater and deepwater (fig. 40). 


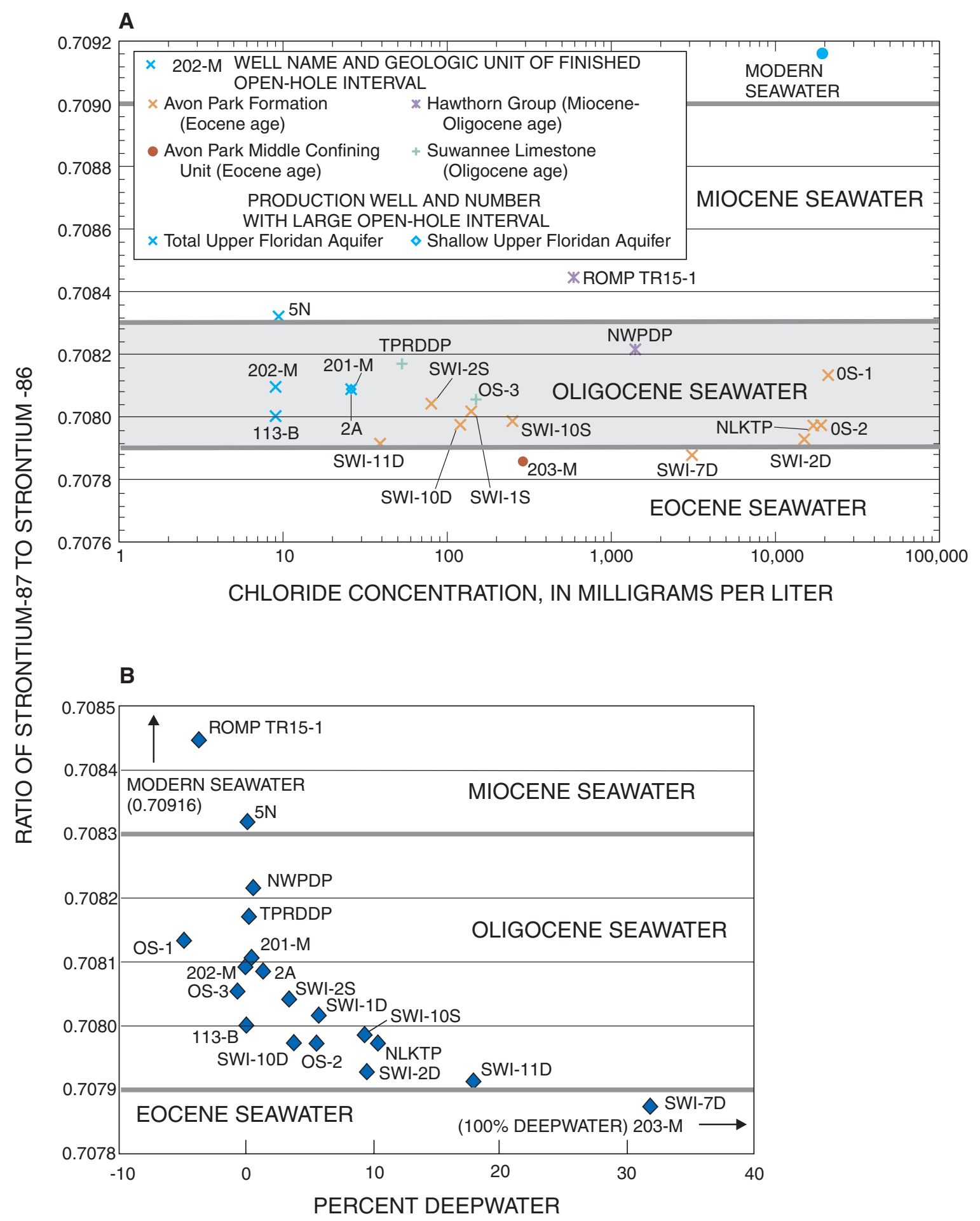

Figure 40. Relation between strontium isotope data and geologic units with (A) chloride concentrations and (B) sulfate enrichment above that from saltwater mixing. Strontium age boundaries based on Hess and others (1986). 


\section{Conceptual Model for Ground-Water Flow Patterns and Mixing}

The data presented in this report were used to develop a conceptual hydrogeologic model that explains the distribution of chloride concentrations in the ground water of the study area. The distribution of hydraulic properties, permeable zones, borehole geophysical $\log$ s, and water-quality data indicate that elevated chloride concentrations within the EW well field originate from two main sources: (1) mineralized ground water from the lower parts of the UFA and (2) saltwater from the salt- water interface. The lowered potentiometric surface in the area of the EW well field creates the potential for upconing and localized lateral movement of ionically enriched waters into producing zones in the well field. Ground waters of different types are mixed and distributed throughout the well field along preferential permeable zones, fractures, and boreholes.

The depth of the 250-mg/L isochlor ranges from near land surface to $1,000 \mathrm{ft}$ below land surface within the study area. Directly south and west of the well field, the $250-\mathrm{mg} / \mathrm{L}$ isochlor is at a depth of 600 to $1,000 \mathrm{ft}$, but near Lake Tarpon the depth ranges from less than 100 to more than $600 \mathrm{ft}$ below land surface (figs. 35, 41). Coastal drainage systems directly west of

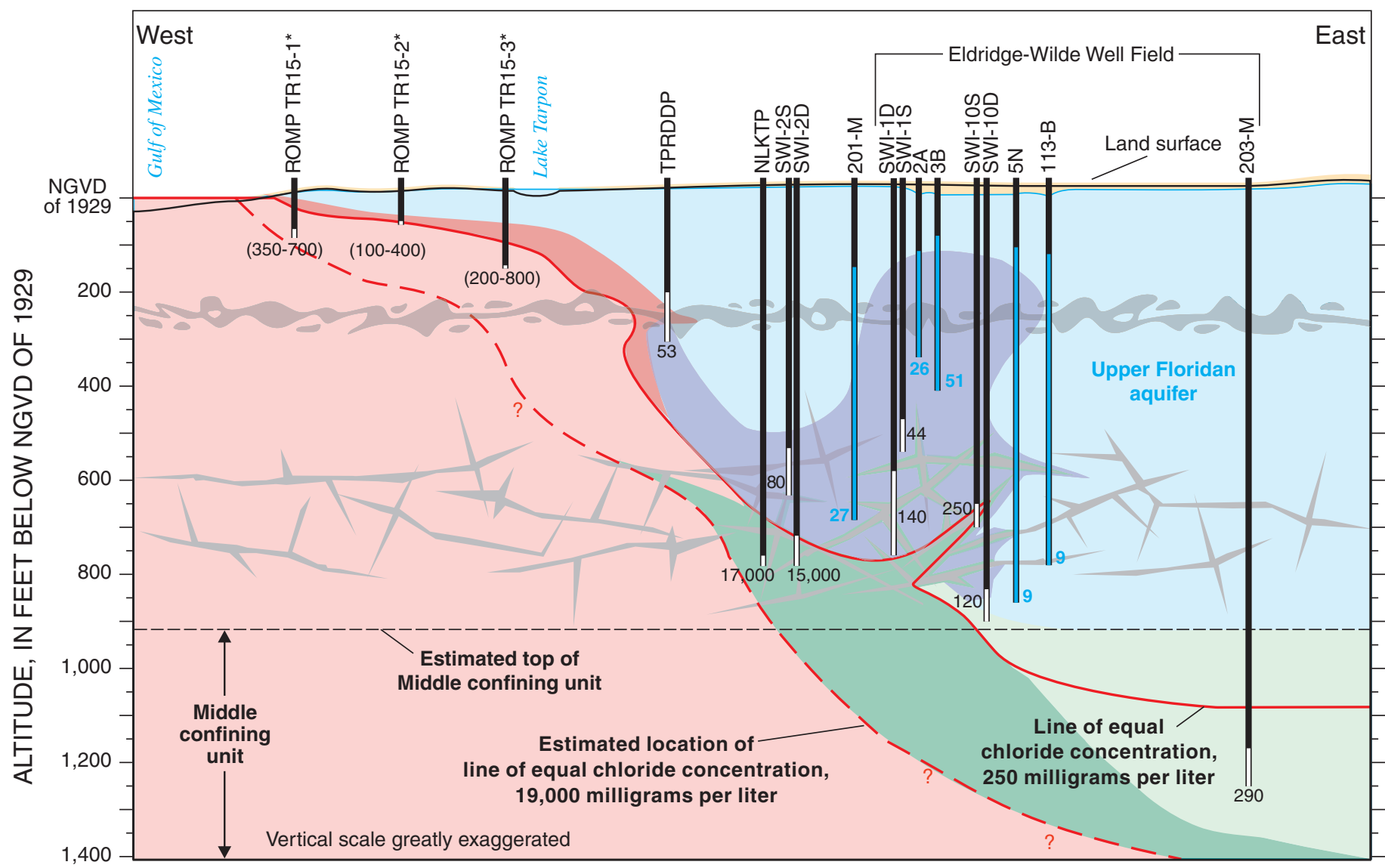

EXPLANATION
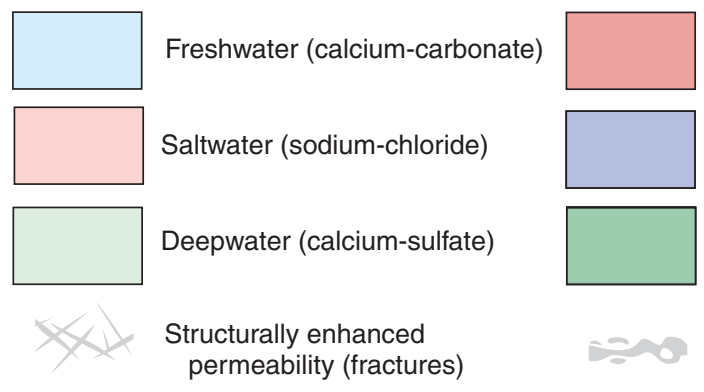

Freshwater-saltwater mixing

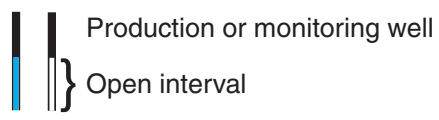

Freshwater mixing with deepwater and saltwater

Deepwater mixing with saltwater

Dissolution-enhanced permeability
953 Chloride concentration, in milligrams per liter, (-) indicates range. Blue indicates a composite aquifer sample. Sampling dates are shown in appendix B.

$5 \mathrm{~N}$ Well name, $\left({ }^{*}\right)$ indicates chloride data are from Southwest Florida Water Management District (1995, 2000b)

Figure 41. Schematic section of observed chloride concentrations in wells located within and west of the Eldridge-Wilde well field, incorporating the conceptual model for aquifer heterogeneity and ground-water pumping conditions. 
the well field, along the Anclote River and Salt Lake Bayou, provide avenues for tidally influenced saltwater to move inland from the Tarpon Springs area. Based on data collected during this study, moderately saline ground water to the west and south appears to have migrated inland preferentially along zones of high transmissivity within the UFA. These zones were the first to exhibit increases in chloride concentrations and also have exhibited the highest chloride values.

Chloride concentrations in wells west of the well field within the freshwater/saltwater transition zone (from land surface to about $500 \mathrm{ft}$ deep in the study area where freshwater and saltwater mix) range from 100 to $1,000 \mathrm{mg} / \mathrm{L}$ and are substantially lower than concentrations found within the saltwater interface (Trommer, 1993; fig. 41). Wells in the transition zone west of the EW well field that are open to the Tampa/ Suwannee producing zone have shown increasing chloride concentrations with time, and wells open to the Tampa/Suwannee producing zone within the well field show a similar trend. The increasing chloride trend indicates that saltwater moves along the transmissive Tampa/Suwannee Limestones, possibly from the Salt Lake Bayou area located to the west. Wells 2A and $3 \mathrm{~B}$, where some of the highest chloride values for production wells were measured, are open to the upper $500 \mathrm{ft}$ of the UFA, and ground water flows along distinct permeable zones within the Tampa/Suwannee Limestones. Wells 2A and 3B are near production wells $4 \mathrm{~A}$ and 5 , which have relatively high specific capacity values and are pumped at double the rate of other wells in the area. Well 4A is $210 \mathrm{ft}$ deep and penetrates the upper part of the Tampa/Suwannee producing zone, which is a highly productive shallow flow zone. The permeable zones in wells $2 \mathrm{~A}$ and $3 \mathrm{~B}$ likely are connected to the production wells by way of permeable zones, because ground-water pumping appears to affect the quality of water in wells $2 \mathrm{~A}$ and $3 \mathrm{~B}$. The influence of pumping from wells $4 \mathrm{~A}$ and 5 , which penetrate a shallow, highly transmissive part of the Tampa/Suwannee producing zone, likely induces ground-water movement along discrete zones within this part of the well field.

Ground water from well $5 \mathrm{~N}$ shows a well-defined increase in chloride concentrations with time (type 1), indicating that the well consistently receives excess chloride from some source. The increased specific conductance at well $5 \mathrm{~N}$ corresponds to a high flow zone within the Tampa/Suwannee producing zone. The apparent movement of water into and out of the borehole along this permeable interval indicates that this zone may be a source of water with high specific conductance (fig. 20). Well $5 \mathrm{~N}$ receives and loses substantial amounts of ground water through the Tampa/Suwannee producing zone; an increase in chloride concentrations of more than $20 \mathrm{mg} / \mathrm{L}$ was observed in well $5 \mathrm{~N}$ from 1987 to 1990 . After 1990, however, the chloride concentrations decreased to background levels (about $10 \mathrm{mg} / \mathrm{L}$ ), possibly due to reduced pumping stress on the Tampa/Suwannee producing zone during the early 1990s. Ground-water movement within the Tampa/Suwannee producing zone could be an important source of chloride.
Over time, chloride concentrations in production wells have increased in an inland (northeastern) direction (fig. 26). The most rapid increases in chloride concentrations occurred when pumping increased in the Avon Park producing zone (figs. 13, 23). Increased withdrawals from the Ocala/Avon Park and Avon Park producing zones causes preferential lateral groundwater movement along the highly transmissive producing zone between 600-750 ft deep. Below a depth of $800 \mathrm{ft}$, the Avon Park is less fractured and less transmissive. Ground-water samples obtained from depths below the Avon Park transmissive zone show chemical influence of mineralized ground water associated with the MCU, but samples have relatively low chloride concentrations, indicating that this zone is less affected by the lateral movement of saltwater because of the low transmissivity.

Ground water moves laterally at a faster rate within the highly transmissive zone in the Avon Park Formation than vertically through the poorly transmissive MCU. Chloride concentrations in ground water in the southwestern part of the well field above and below the Avon Park producing zone are substantially lower than within the producing zone, but south and west of the well field specific conductance and chloride values within the Avon Park producing zone are similar to seawater concentrations.

More than 40 percent of the 54 production wells active at the EW well field during this study tap the Avon Park producing zone (app. A). Nearly half of the water pumped at the well field (43 percent) is from wells with more than $500 \mathrm{ft}$ of open hole penetrating the highly transmissive 600-750 ft zone.

The predevelopment pattern of westward ground-water flow has changed over time (fig. 14). Ground-water withdrawals have likely caused local reversals in the hydraulic gradient, thus increasing the potential for landward movement of saline ground water into the well field along permeable zones and fractures within the Avon Park producing zone. Although chloride concentrations equivalent to seawater do not occur within the well field, water with chloride concentrations greater than 250 $\mathrm{mg} / \mathrm{L}$ moved inland 3,000 ft in the southwestern part of the well field between 1997 and 2000 (Water and Air Research, Inc., and others, 2001). The relative location of the $250-\mathrm{mg} / \mathrm{L}$ isochlor from 1992 to 2000 shows how this boundary has moved over time (fig. 26). Declines in the potentiometric surface below NGVD of 1929 can be important with respect to the location of the saltwater interface. Periods of extreme low water levels and high pumpage can further affect regional flow, thereby increasing the potential for saltwater intrusion or deepwater upconing.

The permeability differences between the Tampa/Suwannee and Avon Park producing zones and the Ocala semiconfining unit appear to create a distinct distribution of water types and their ionic concentrations within the study area (fig. 41). Rates and patterns of ground-water movement differ between aquifers dominated by primary or secondary porosity. The rates and directions of ground-water flow in a doubly porous system (system with both primary and secondary porosity) can vary substantially (Knochenmus and Robinson, 1996). Flow zones and continuous specific conductance data observed in the 


\section{Effects of Aquifer Heterogeneity on Ground-Water Flow and Chloride Concentrations, West-Central Florida}

Tampa/Suwannee and the Avon Park producing zones indicate that substantial secondary porosity results in well-developed conduit networks along which ground water moves preferentially and at higher velocities. In contrast, little preferential flow occurs within the Ocala semiconfining unit, but the high primary porosity and vertical hydraulic conductivities (Loizeaux, 1995) likely contribute to diffusive intergranular ground-water flow, which is relatively slow and uniform. Although both primary and secondary porosity occur within the interlayered aquifer system, the majority of measured borehole flow and water-quality changes occur along discrete secondary porosity features. Intergranular flow appears to be insignificant when compared to flow in zones with substantial secondary porosity. Although elevated chloride concentrations appear to originate from seawater at shallower depths (200-300 ft) within the Tampa/Suwannee producing zone and at deeper depths (500-750 ft) within the Avon Park/Ocala and Avon Park producing zones (fig. 36), elevated sulfate concentrations, beyond those explained by saltwater mixing, indicate that upward migration of deep mineralized ground water also contributes to increases in chloride (fig. 37). Natural upwelling has not been documented in the study area; however, localized effects of ground-water withdrawals can introduce deepwater into shallow units and create ground-water mixtures that are chemically similar to those observed in natural upwelling areas (fig. 22b,c). The lowering of ground-water levels associated with pumping from wells $4 \mathrm{~A}$ and 5 creates the potential for upward movement of ground water to wells. Nearby pumping stresses affect wells by changing head gradients and increasing the potential for ground-water flow along permeable intervals, subsequently altering the composition of water within the borehole and causing the observed changes in specific conductance over time (figs. 31 and 33). The greatest influence of deep mineralized ground water appears to be in the southwestern part of the well field, coincident with the cone of depression and the greatest increases in historical chloride concentrations. Toward the north and central part of the well field, less evidence of the deepwater chemical signature exists (fig. 41).

Deep ground-water movement both along primary and secondary porosity features likely contributes to the observed distribution of water types throughout the study area. Mineralized ground water appears well dispersed throughout the southwestern part of the well field as a result of upward migration. Because the deepwater signature is well distributed within the southwestern part of the well field, intergranular flow of deepwater through the Ocala semiconfining unit probably occurs in response to upconing. Within the southwestern part of the well field, however, the seismic reflection data and the presence of photolinear features indicate that particular stratigraphic units may be discontinuous, and these disruptions may create more effective hydraulic connections through the semiconfining unit, thereby enhancing vertical flow.
Ground-water movement along permeable intervals, highangle fractures, and boreholes may provide more localized avenues for upward movement of saltwater and deepwater. Once this water enters shallow flow zones within the aquifer, it can travel from one production well to another, mixing various water types within the well field. Fractures that connect water from deep mineralized zones or the saltwater interface to shallow zones can introduce high ionic concentrations into the shallow zones. Wells with high specific capacity values (open to more producing zones) or large open-hole intervals probably intersect numerous permeable intervals. Conversely, permeable intervals contributing freshwater result in an overall dilution of ionic concentrations within a well. Consequently, whether ionic concentrations are diluted or increased depends on the percentage of the total flow contribution and water-quality characteristics of each permeable interval.

Even minor contributions of water to a well from a saltwater source, when compared to similar contributions from a deepwater source, can significantly affect chloride concentrations. For example, a 1-percent solution of saltwater has a chloride concentration of approximately $190 \mathrm{mg} / \mathrm{L}$ whereas a 1-percent solution of deepwater has a chloride concentration of approximately $2.9 \mathrm{mg} / \mathrm{L}$. Although ground water from wells tapping shallow production zones, such as wells $2 \mathrm{~A}$ and $3 \mathrm{~B}$ within the well field, is composed of more than 97 percent freshwater, the influence of saltwater on water quality is substantial. Chloride concentrations at wells $2 \mathrm{~A}$ and $3 \mathrm{~B}$ were 26 and $51 \mathrm{mg} / \mathrm{L}$, respectively, corresponding to low relative percent contributions of saltwater $(0.09$ and 0.2 , respectively) (table 3 ). The percentages of the total chloride concentrations supplied to the sample by each water type are calculated by multiplying the chloride concentration of the respective end member by the percent fraction of the end member found in that sample. For example,

$$
\left[\left(0.2_{(x)} * 19,000 \mathrm{mg} / \mathrm{L}_{(y)}\right]=38 \mathrm{mg} / \mathrm{L}_{(z)},\right.
$$

where

$x$ is percent fraction of saltwater contribution to well $3 \mathrm{~B}$; $y$ is chloride concentration in saltwater end member; and $z$ is chloride concentration at well $3 \mathrm{~B}$ derived from saltwater fraction.

At well 3B, $38 \mathrm{mg} / \mathrm{L}$ (74 percent) of the total $51 \mathrm{mg} / \mathrm{L}$ chloride was derived from saltwater, while $8 \mathrm{mg} / \mathrm{L}$ was from a deepwater source. Of the total chloride concentrations found in samples from wells $2 \mathrm{~A}$ and $3 \mathrm{~B}, 65$ and 75 percent of the total chloride, respectively, were derived from saltwater, 16 and 17 percent, respectively, were derived from deepwater and 10 and 19 percent, respectively, were associated with the background from the freshwater fraction. Therefore, even if water within the Tampa/Suwannee producing zone has only a small fraction of seawater, most of the chloride is derived from a saltwater source.

A nearby saltwater source, containing chloride concentrations from 15,000 to 17,000 mg/L, occurs south and west of the well field near the saltwater interface (wells NLKTP, SWI-2D, SWI-6D, and SWI-7D). This saltwater source contributes to increased chloride concentrations observed in wells that tap the Avon Park producing zone between 640-780 ft deep near and 
within the well field. Within the Avon Park producing zone in the middle of the well field, ground water containing $250 \mathrm{mg} / \mathrm{L}$ chloride was a mixture of approximately 1 percent saltwater, 9 percent deepwater, and 90 percent freshwater (well SWI-10S). The saltwater source contributed 87 percent of the total chloride in this well, whereas only 11 percent originated from deepwater.

Ground-water movement and changes in specific conductance in the EW well field were associated with enlarged borehole conditions and fractures within the Tampa/Suwannee and the Avon Park producing zones. Ground water moves along preferred flowpaths within the permeable zones, and wells can act as vertical connections between the zones. Specific conductance and flow logs indicate that water with high specific conductance from the Avon Park producing zone can enter a well, migrate upward, and exit at shallower depths along permeable intervals within the Tampa/Suwannee producing zone. Similarly, water with high specific conductance can enter other wells from shallow permeable intervals within the Tampa/Suwannee producing zone. Within the well field, even wells that are dominantly freshwater contain measurable percentages of both deepwater and saltwater. A network of permeable intervals and fractures contributes deepwater and saltwater fractions to the relatively shallow Tampa/Suwannee producing zone.

Evidence of ground-water movement between permeable intervals within an open borehole was observed in all wells where flow and fluid logging data were collected. This complex network of flow zones, boreholes with large open-hole sections, and pumping wells is an important mechanism for introducing, transporting, and diluting chloride concentrations throughout producing zones within the EW well field (fig. 17). In an aquifer with multiple permeable intervals, there are many competing flowpaths of relatively high permeability. High chloride water can shift from one path to another as a function of the way each pumping well affects the flow in a particular permeable interval. If the pattern of drawdown changes, water with different chloride concentrations can be pulled into different permeable intervals carrying flow in different directions. Changes in relative contributions of high chloride water can create shifts in specific conductance or spikes in chloride concentrations recorded over time.

Changes in head gradients and gradient reversals produced by changes in pumping rates at individual wells in the well field complicate local ground-water flow patterns. Complexities observed in continuously recorded specific conductance, borehole-flow measurements, and water-quality data at individual wells appear to be related to nearby pumping, permeable zones intercepted by the borehole, and well location. Wells along the boundaries of the well field, farther from production wells, exhibited spikes in chloride concentrations even though increasing trends did not exist. Anomalous spikes in the chloride concentrations also have been observed in production wells in the northern part of the well field, indicating that they periodically receive a greater contribution of high conductance water from the permeable zones. Chloride concentrations along specific flow zones are dispersed by mixing with water from other flow zones, either along preferential flow paths or in production wells. The result is a heterogeneous distribution of chloride concentrations, with fluctuations in specific conductance with depth and the interlayering of high chloride waters between zones of freshwater (fig. 41).

\section{Summary}

Chloride concentrations in ground water have been increasing at the Eldridge-Wilde (EW) well field for several decades. In 1975, chloride concentrations were less than 20 $\mathrm{mg} / \mathrm{L}$ in the southwestern part of the well field. By 1996, chloride concentrations had increased to more than $100 \mathrm{mg} / \mathrm{L}$ at several wells and to more than $20 \mathrm{mg} / \mathrm{L}$ in surrounding wells in the same area. Increasing trends in individual wells and the elongated northeast-southwest pattern of high chloride concentrations indicated that structural heterogeneity within the aquifer was affecting the movement of chlorides.

This study used multiple techniques to determine how and where aquifer properties are related to geologic characteristics, to identify permeable intervals and mechanisms for observed ground-water flow, and to clarify sources of observed increases in chloride concentrations. Acoustic televiewer and caliper logs provided evidence of fractures and enlarged boreholes associated with poorly lithified units and dissolution features. The logging data, combined with borehole fluid and flow logs, were used to identify permeable intervals and the types of geologic features that created them. Continuous monitoring of water levels and specific conductance and water-quality analyses provided information about ground-water flow patterns and mixing. Together, these techniques were used to help define the hydrogeologic controls on ground-water movement within the study area.

The Upper Floridan aquifer (UFA) comprises a multilayered sequence of carbonate rocks with each sequence characterized by different hydrogeologic properties. Highly transmissive zones, corresponding to well-developed secondary porosity, appear to control ground-water flow and observed changes in water quality. Highly transmissive zones are associated with the Tampa/Suwannee Limestones and the Avon Park Formation. Well-developed dissolution features and fractures within the Tampa/Suwannee Limestones and the Avon Park Formation serve as highly transmissive pathways for ground-water movement. The Ocala semiconfining unit separates the two producing zones. Although the Ocala semiconfining unit is less permeable relative to the producing zones above and below it, the unit has substantial intergranular porosity. Fractures observed in the acoustic televiewer data range from horizontal to near vertical and are associated primarily with the Avon Park producing zone; however, dolomitized sections of the Ocala/Avon Park producing zone and the Ocala semiconfining unit also may contain fractures. High angle fractures are capable of providing vertical connections between other permeable zones. Land-based seismic-reflection data indicate that dolomite units may be laterally discontinuous in the southwestern 
part of the well field owing to fractures. Discontinuities in the dolomite units and fractures within the Avon Park Formation may extend into shallower stratigraphic units.

The timing of well-field expansion to the north and into deeper parts of the UFA corresponds to observed increases in chloride concentrations in wells located within the southwestern part of the well field. Ground-water withdrawals in the EW well field have lowered ground-water levels and altered ground-water flow patterns from predevelopment conditions. Changes in ground-water flow patterns have been accompanied by increases in chloride concentrations at some wells. The amount and variability of observed increases in chloride concentrations at each well are related to well location and permeable intervals intercepted by the borehole.

Flow measurements indicate that ground water moves in response to changes in the head gradients along permeable zones within the UFA. Pumping stresses can induce flow through a complex network of permeable intervals, boreholes, and fractures that can affect water quality by connecting zones of poor quality to those with better quality. Production wells open to the entire length of the UFA that intersect more than one permeable zone can convey deep mineralized ground water into shallow producing zones.

Water quality within the UFA varies depending on well location and depth interval sampled. Within the study area, water from the UFA is a calcium-bicarbonate-type freshwater that has been enriched to varying degrees by mixing with saltwater and deepwater (calcium-sulfate-type water). Both deepwater and saltwater are the likely sources for elevated chloride and sulfate concentrations within the ground water. Deepwater is present beneath the well field just above and within the MCU. The saltwater interface in the Avon Park producing zone (chloride concentrations greater than $10,000 \mathrm{mg} / \mathrm{L}$ ) is approximately 1 mile west of the well field.

Wells located closest to the saltwater interface show the greatest increases in chloride concentrations over time, indicating a source of chloride to the southwest. The $250-\mathrm{mg} / \mathrm{L}$ isochlor within the Avon Park producing zone has migrated to the northeast over time. Increased chloride concentrations within the production wells are oriented northeast-southwest with well-defined increases found in wells that are within the center of the southwestern part of the well field. In this part of the well field, chloride concentrations exceed $250 \mathrm{mg} / \mathrm{L}$ in the Avon Park producing zone.

Water-quality data and mass-balance calculations were used to determine sources of chloride and mixing of waters of different origins. These data indicate that elevated chloride concentrations within the EW well field are due to mixing of both deepwater and saltwater. Nearly all wells in the southwestern part of the well field also show an influence from deepwater as it migrates into the shallow permeable units, contributing to elevated sulfate and chloride concentrations. Saltwater is an additional source of chloride. Because chloride concentrations in saltwater are greater than those associated with deepwater, even a small amount of saltwater has a large effect on chloride concentrations.
The preferential movement of saltwater along fractures within the highly transmissive Avon Park producing zone has the potential to affect water quality throughout the well field. In 2000 , the $250-\mathrm{mg} / \mathrm{L}$ isochlor was located beneath the center of the southwestern part of the well field about $700 \mathrm{ft}$ below land surface (well SWI-10S). Temporal fluctuations in the location of the $250-\mathrm{mg} / \mathrm{L}$ isochlor indicate that the isochlor migrates with time.

A conceptual model of ground-water movement and variability in chloride concentrations was developed from the hydrogeologic and water-quality data to describe flow paths and mixing within the study area. Most ground-water movement is through the Tampa/Suwannee and the Avon Park producing zones, which are preferential flow paths within the aquifer system. Substantial changes in ground-water quality also occur along these flow paths. Water-quality analyses for specific wells indicate mixing from different flow zones. The movement of deepwater and saltwater along these preferential flow paths and the subsequent mixing with potable ground water has resulted in increased concentrations of chloride and sulfate in these producing zones.

\section{Selected References}

Arthur, J.A., Lee, R.A., and Li, L., 2001, Lithostratigraphic and hydrostratigraphic cross-sections through Levy-Marion to Pasco Counties, southwest Florida: Tallahassee Florida Geological Survey, Open-File Report 81, 22 p.

Barbier, M.G., 1983, The Mini-SOSIE method: Boston, Massachusetts, International Human Resources Development Corp., 86 p.

Barlow, P.M., 2003, Ground water in freshwater-saltwater environments of the Atlantic Coast: U.S. Geological Survey Circular 1262, 113 p.

Barr, G.L., 1982, Ground-water levels in selected well fields and in west-central Florida, May 1982: U.S. Geological Survey Open-File Report 82-867, 2 sheets.

Barr, G.L., 1983, Ground-water levels in selected well fields and west-central Florida, September 1982: U.S. Geological Survey Open-File Report 83-31, 2 sheets.

Black, Crow, and Eidsness, Inc., 1970, Water resources investigations for the Pinellas County water system, Pinellas County, Florida: Engineering report prepared for the Board of County Commissioners, Project No. 272-69-51, variably paginated.

Blasland, Bouck, and Lee, R.A., 1997, The 1996 annual well field operation and hydrologic assessment report-EldridgeWilde well field: Report prepared for Pinellas County Utilities, February 1997, variably paginated.

Broska, J.C., and Barnette, H.L., 1999, Hydrogeology and analysis of aquifer characteristics in west-central Pinellas County, Florida, U.S. Geological Survey Open-File Report 99-185, 23 p. 
Bush, P.W., and Johnston, R.H., 1988, Ground-water hydraulics, regional flow, and ground-water development of the Floridan aquifer system in Florida and in parts of Georgia, South Carolina, and Alabama: U.S. Geological Survey Professional Paper 1403-C, 80 p.

CH2M Hill, Inc., 1990a, Drilling and testing of well no. 1-D, northwest Hillsborough water resources assessment project: Brooksville, Southwest Florida Water Management District.

CH2M Hill, Inc., 1990b, Drilling and testing of wells 2-D, 3-D, and 4-D northwest Hillsborough water resources assessment project: Brooksville, Southwest Florida Water Management District.

Cander, H.S., 1991, Dolomitization and water-rock interaction in the middle Eocene Avon Park Formation, Floridan aquifer: Doctor of Philosophy Dissertation, University of Texas at Austin, $172 \mathrm{p}$.

Carter, B.D., Beisel, T.H., Branch, W.B., and Mashburn, C.M., 1989, Substrate preferences of Late Eocene (Priabonian/ Jacksonian) echinoids of the eastern Gulf Coast: Journal of Paleontology, v. 63, p. 495-503.

Causseaux, K.W., and Fretwell, J.D., 1982, Position of the saltwater-freshwater interface in the upper part of the Floridan aquifer, southwest Florida, 1979: U.S. Geological Survey Water-Resources Investigations Open-File Report 82-90, 1 sheet.

Cherry, R.N., 1966, Chloride content of ground water in Pinellas County, Florida, in 1950 and 1963: Tallahassee, Florida Geological Survey Map Series 20, 1 sheet.

Colwell, R.N., ed., 1960, Manual of photographic interpretation: Menasha, Wisc., American Society of Photogrammetry, $504 \mathrm{p}$.

Cooper, H.H., Jr., Kohout, F.A., Henry, H., and Glover, R.E., 1964, Sea water in coastal aquifers, U.S. Geological Survey Water-Supply Paper 1613-C, 84 p.

Cunningham, K.J., 2004, Application of ground-penetrating radar, digital optical borehole images, and core for characterization of porosity hydraulic conductivity and paleokarst in the Biscayne aquifer, southeastern Florida, USA: Journal of Applied Geophysics, v. 55, p. 61-76.

Cunningham, K.J., Carlson J.I., and Hurley, N.F., 2004, New method for quantification of vuggy porosity from digital optical borehole images as applied to the karstic Pleistocene limestone of the Biscayne aquifer, southeastern Florida: Journal of Applied Geophysics, v. 55, p. 77-90.

Dames and Moore, 1988, Final report: Tri-county saltwater intrusion model Volume 1: Project report prepared for Southwest Florida Water Management District, 150 p.

Diodato, D.M., 1999, Fracture trace mapping of the EldridgeWilde well field, Pinellas County, Florida, U.S. Geological Survey Open-File Report 99-235, 13 p.

Driscoll, F.G., 1986, Groundwater and wells: St. Paul, Minn., Johnson Filtrations Systems, Inc., 1089 p.

Duerr, A.D., 1995, Types of secondary porosity in carbonate injection intervals and overlying rocks in southern peninsular Florida: U.S. Geological Survey Water-Resources Investigations Report 94-4013, 78 p.
Duerr, A.D., 2001, Potentiometric surface of the Upper Floridan aquifer, west-central Florida, May 2000; U.S. Geological Survey Open-File Report 01-20, 1 sheet

Dunham, R.J., 1962, Classification of carbonate rocks according to depositional texture, in W.E., Ham (ed.), Classification of carbonate rocks. AAPG Mem., 1, p. 108-121.

ERM, 2000, Water quality evaluation program: Phase I-Status of water quality monitoring: Report prepared for Tampa Bay Water, variably paginated.

Gee and Jenson Inc., 1981a, Eldridge-Wilde well field modification program Phase 1: Report prepared for Pinellas County Water System, 35 p.

Gee and Jenson Inc., 1981b, Eldridge-Wilde well field modification program Phase 2: Report prepared for Pinellas County Water System, 6 p.

Gee and Jenson Inc., 1983, Eldridge-Wilde well field modification program Phase 3: Report prepared by Nettles and Vandor for Pinellas County Water System, 14 p.

Geraghty \& Miller, Inc., 1976a, Management of the water resources of the Pinellas-Anclote and northwest Hillsborough basins west-central Florida: Volume I, variably paginated.

Geraghty \& Miller, Inc., 1976b, Management of the water resources of the Pinellas-Anclote and northwest Hillsborough basins west-central Florida: Volume II.

Green, R., Arthur, J.D., and DeWitt, D.J., 1995, Lithostratigraphic and hydrostratigraphic cross sections through Pinellas and Hillsborough Counties, southwest Florida: Tallahassee, Florida Geological Survey Open-File Report 61, 26 p.

Hammes, Ursula, 1992, Sedimentation patterns, sequence stratigraphy, cyclicity, and diagenesis of early Oligocene carbonate ramp deposits, Suwannee Formation, southwest Florida, USA: Doctor of Philosophy thesis, University of Colorado, $344 \mathrm{p}$.

Heath, R.C., and Smith, P.C., 1954, Ground-water resources of Pinellas County, Florida: Tallahassee, Florida Geological Survey Report of Investigations 12, 139 p.

Hem, J.D., 1985, Study and interpretation of chemical characteristics of natural water ( $3 \mathrm{~d}$ ed.): U.S. Geological Survey Water-Supply Paper 2254, 263 p.

Hess, J., Bender, M.L., and Schilling, J.G., 1986, Evolution of the ratio of strontium-87 to strontium-86 in seawater from Cretaceous to present: Science, v. 231, p. 979-984.

Hickey, J.J., 1982, Hydrogeology and results of injection tests at waste-injection test sites in Pinellas County, Florida: U.S. Geological Survey Water-Supply Paper 2183, 42 p.

Hickey, J.J., 1990, An assessment of the flow of variable-salinity ground water in the middle confining unit of the Floridan aquifer system, west-central Florida: U.S. Geological Survey Water-Resources Investigations Report 89-4142, 13 p.

Hunn, J.D., 1974, Hydrology of Lake Tarpon near Tarpon Springs, Florida, Tallahassee, Florida Geological Survey Map Series 60, 1 sheet. 
Hutchinson, C.B., 1992, Assessment of hydrogeologic conditions with emphasis on water quality and water injection, southwest Sarasota and west Charlotte Counties, Florida: U.S. Geological Survey Water-Supply Paper 2371, 74 p.

Hutchinson, C.B., and Mills, L.R., 1977, Water table in the surficial aquifer in selected well fields, west-central Florida, May 1976: U.S. Geological Survey Open-File Report $77-$ 257, 14 p., 4 sheets.

Hutchinson, C.B., Sanders, G.L., and Duerr, A.D., 1993, Underground injection in southwest Florida: U.S. Geological Survey Open-File Video Report 93-450.

HydroGeologic, Inc., 1992, Safe yield model (SYM) analysis in the vicinity of Eldridge-Wilde and East Lake Road well fields, Pinellas County, Florida: Final report prepared for the Pinellas County Water System, variably paginated.

Johnston, R.H., Krause, R.E., Meyer, F.W., Ryder, P.D., Tibbals, C.H., and Hunn, J.D., 1980, Estimated potentiometric surface for the Tertiary limestone aquifer system, southeastern United States, prior to development: U.S. Geological Survey Open-File Report 80-406, 1 sheet.

Joyner, B.F., and Gerhart, J.M., 1980, Hydrologic monitoring program in Eldridge-Wilde and East Lake Road well-field areas, Pinellas and Hillsborough Counties, Florida, 1977 water year: U.S. Geological Survey Open-File Report 80-345, 34 p.

Keys, W.S., 1990, Borehole geophysics applied to groundwater investigations: U.S. Geological Survey Techniques of Water-Resources Investigations, chap. E-2, 150 p.

Knochenmus, L.A., and Bowman, G.M., 1998, Transmissivity and water quality of water-producing zones in the intermediate aquifer system, Sarasota County, Florida: U.S. Geological Survey Water-Resources Investigations Report 98-4091, $27 \mathrm{p}$.

Knochenmus, L.A., and Robinson, J.L., 1996, Descriptions and anisotropy and heterogeneity and their effect on groundwater flow and areas of contribution to public supply wells in a karst carbonate aquifer system: U.S. Geological Survey Water-Supply Paper 2475, 47 p.

Knochenmus, L.A., and Swenson, E.S., 1996, Assessment of the fresh- and brackish-water resources underlying Dunedin and adjacent areas of northern Pinellas County, Florida: U.S. Geological Survey Water-Resources Investigations Report 96-4164, 47 p.

Knochenmus, L.A., and Thompson, T.H., 1991, Hydrogeology and simulated development of the brackish ground-water resources in Pinellas County, Florida: U.S. Geological Survey Water-Resources Investigations Report 91-4026, $20 \mathrm{p}$.

Lattman, L.H., 1958, Technique of mapping geologic fracture traces and lineaments on aerial photographs, Photogrammetric Engineering, v. 24, p. 1748-1759.

Leggette, Brashears, and Graham, Inc., 1995, Eldridge-Wilde and East Lake well fields 1994 annual hydrogeologic report, Pinellas County, prepared for the Pinellas County Water System, 13 p.
Leggette, Brashears, and Graham, 1996, Eldridge-Wilde and East Lake well fields, 1995 annual hydrogeologic report, Pinellas County, prepared for the Pinellas County Water System, $11 \mathrm{p}$.

Loizeaux, N.T., 1995, Lithologic and hydrogeologic frameworks for a carbonate aquifer: Evidence for facies controlled hydraulic conductivity in the Ocala Formation, west-central Florida: Master of Science thesis, University of Colorado, $298 \mathrm{p}$.

Maddox, G.M., Lloyd, J.M., Scott, T.M., Upchurch, S.B., and Copeland, R., 1992, Florida's ground-water quality monitoring program-background hydrogeochemistry: Tallahassee, Florida Geological Survey Special Publication 34, 364 p.

Maslia, M.L., and Prowell, D.C., 1990, Effect of faults on fluid flow and chloride contamination in a carbonate aquifer system: Journal of Hydrology, v. 115, p. 1-49.

Metz, P.A., and Brendle, D.L., 1996, Potential for water-quality degradation of interconnected aquifers in west-central Florida, U.S. Geological Survey Water-Resources Investigations Report 96-4030, 54 p.

Metz, P.A., and Sacks, L.A., 2001, Comparison of the hydrogeology and water-quality of a ground-water augmented lake with two non-augmented lakes in northwest Hillsborough County, Florida, U.S. Geological Survey Water-Resources Investigations Report 02-4032, 74 p.

Miller, J.C., 1977, Fracture trace analysis for well siting in carbonate karst terrane, Crossbar Ranch well field, Pasco County, Florida: Report to the West Coast Regional Water Supply Authority, $10 \mathrm{p}$.

Miller, J.A., 1986, Hydrogeologic framework of the Floridan aquifer system in Florida and in parts of Georgia, Alabama, and South Carolina: U.S. Geological Survey Professional Paper 1403-B, 91 p.

Montgomery Watson Americas, Inc., 2001, Eldridge-Wilde well field water quality study-Phase 1-Data evaluation for development of wellfield operational strategies: Report prepared for Tampa Bay Water, variably paginated.

Nettles and Associates Inc., 1989, Eldridge-Wilde wellfield modification program monitor well construction-Phase 9: Report prepared for Pinellas County Board of County Commissioners and Pinellas County Water System, 12 p.

Nettles and Associates Inc., 1990, Well completion report for well SWI-10S, Eldridge-Wilde well field: Report prepared for Pinellas County Board of County Commissioners and Pinellas County Water System, 5 p.

Nettles and Associates Inc., 1991a, Well completion report for well SWI-4D and SWI-12D, Eldridge-Wilde wellfield: Report prepared for Pinellas County Board of County Commissioners and Pinellas County Water System, 10 p.

Nettles and Associates Inc., 1991b, Well completion report for well SWI-3D and SWI-3S, and SWI-11D Eldridge-Wilde well field: Report prepared for Pinellas County Board of County Commissioners and Pinellas County Water System, $13 \mathrm{p}$. 
Nettles and Associates Inc., 1991c, Well-completion report for wells SWI-7D, SWI-10D, and SWI-18D Eldridge-Wilde well field: Report prepared for Pinellas County Board of County Commissioners and Pinellas County Water System, $14 \mathrm{p}$.

Nettles and Associates Inc., 1992a, Well construction report for wells SWI-5D, SWI-7D, and SWI-18S, Eldridge-Wilde and East Lake well fields: Report prepared for Pinellas County Board of County Commissioners and Pinellas County Water System, $13 \mathrm{p}$.

Nettles and Associates Inc., 1992b, Well completion report for well SWI-5S, SWI-15D, 203-M, M8 and SWI-6D EldridgeWilde and East Lake Road wellfields: Report prepared for Pinellas County Water System, 23 p.

Nettles and Associates Inc., 1992c, Saltwater intrusion monitor well construction correlation to hydrogeologic characteristics: Report prepared for Pinellas County Water System, $121 \mathrm{p}$.

Nettles and Vandor Inc., 1983, Sall's property hydrogeologic investigation for potable water supply development: Report prepared for Pinellas County Board of County Commissioners and Pinellas County Water System, 19 p.

Nettles and Vandor Inc., 1985, EW well field modification program Phases 4 and 5: Report prepared for Pinellas County Board of County Commissioners and Pinellas County Water System, $34 \mathrm{p}$.

Nettles and Vandor Inc., 1986, Eldridge-Wilde well field modification program Phase 6: Report prepared for Pinellas County Board of County Commissioners and Pinellas County Water System, 11 p.

Nettles and Vandor Inc., 1988a, Eldridge-Wilde wellfield hydrogeologic evaluation: Report prepared for the Pinellas County Board of County Commissioners and Pinellas County Water System, 87 p.

Nettles and Vandor Inc., 1988b, Chloride trend analysis for Pinellas County water system East Lake Road and EldridgeWilde wellfields: Report prepared for the Pinellas County Board of County Commissioners and Pinellas County Water System, $13 \mathrm{p}$.

Odum, J.K., Stephenson, W.J., Williams, R.A., Pratt, T.L., Toth, D.J., and Spechler, R.M., 1999, Shallow high-resolution seismic-reflection imaging of karst structures within the Floridan aquifer system, northeastern Florida, Journal of Environmental and Engineering Geophysics, v. 4, no. 4, p. 251-261.

Odum, J.K., Stephenson, W.J., Williams, R.A., Worley, D.M., Toth, D.J., Spechler, R.M., and Pratt, T.L., 1997, Land-based high-resolution seismic-reflection surveys of seven sites in Duval and St. Johns Counties, northeastern Florida, U.S. Geological Survey Open-File Report 97-718, 45 p.
Parizek, R.R., and Diodato, D.M., 1995, Fracture trace and lineament analyses and hydrogeological investigations, Combat Maneuver Training Center Hohenfels, Hohenfels, Germany: Report published by R.R., Parizek and Associates, State College, Pa., 16803, and the Center for Environmental Restoration Systems, Energy Systems Division, Argonne, Ill., 60439.

Phelps, G.G., and Spechler, R.M., 1997, Hydrogeology and water quality of the lower Floridan aquifer in Duval County, Florida, and implications for monitoring movement of saline water: U.S. Geological Survey Water-Resources Investigations Report 96-4242, $58 \mathrm{p}$.

Pin, C., and Bassin, C., 1992, Evaluation of a strontium specific extraction chromatographic method for isotopic analysis in geologic materials: Analytica Chimica Acta, v. 269, p. 249255.

Plummer, N.L., Parkhurst, D.L., and Thorstenson, D.C., 1983, Development of reaction models for ground-water systems: Geochimica et Cosmochimica Acta, v. 47, p. 665-686.

Plummer, N.L., and Sprinkle, C., 2001, Radiocarbon dating of dissolved inorganic carbon in ground water from confined parts of the Upper Floridan aquifer, Florida, USA: Hydrogeology Journal, v. 9, p. 127-150.

Richter, B.C., and Kreitler, C.W., 1993, Geochemical techniques for identifying sources of ground-water salinization: Boca Raton, Fla., C.K., Smoley, CRC Press, 258 p.

Robinson, J.L., 1995, Hydrogeology and results of tracer tests at the Old Tampa well field in Hillsborough County, with implications for well head-protection strategies in west-central Florida, U.S. Geological Survey Water-Resources Investigations Report 93-4171, 63 p.

Ryder, P.D., and Mills, L.R., 1977a, Water table in the surficial aquifer and potentiometric surface of the Floridan aquifer in selected well fields, west-central Florida, September 1976: U.S. Geological Survey Open-File Report 77-551, 13 p., and 4 sheets.

Ryder, P.D., and Mills, L.R., 1977b, Water table in the surficial aquifer and potentiometric surface of the Floridan aquifer in selected well fields, west-central Florida, May 1977: U.S. Geological Survey Open-File Report 77-642, 15 p., and 4 sheets.

Ryder, P.D., and Mills, L.R., 1978, Water table in the surficial aquifer and potentiometric surface of the Floridan aquifer in selected well fields, west-central Florida, September 1977: U.S. Geological Survey Open-File Report 78-311, 13 p., and 4 sheets.

Ryder, P.D., 1981, Digital model of predevelopment flow in the tertiary limestone (Floridan) aquifer in west-central Florida, U.S. Geological Survey Water-Resources Investigations $81-54,61 \mathrm{p}$.

Ryder, P.D., 1985, Hydrology of the Floridan aquifer system in west-central Florida, U.S. Geological Survey Professional Paper 1403-F, 63 p. 
Rye, R.O., Back, W., Hanshaw, B.B., Rightmire, C.T., Pearson, F.J., Jr., 1981, The origin and isotopic composition of dissolved sulfide in ground water from carbonate aquifers in Florida and Texas: Geochimica et Cosmochimica Acta, v. 45, p. 1941-1950.

Sacks, L.A., 1996, Geochemical and isotopic composition of ground water with emphasis on sources of sulfate in the Upper Floridan aquifer in parts of Marion, Sumter, and Citrus Counties, Florida, U.S. Geological Survey WaterResources Investigations Report 95-4251, 47 p.

Sacks, L.A., and Tihansky, A.B., 1996, Geochemical and isotopic composition of ground water, with emphasis on sources of sulfate, in the Upper Floridan aquifer and intermediate aquifer system in southwest Florida: U.S. Geological Survey Water-Resources Investigations Report 96-4146, $54 \mathrm{p}$.

Safko, P.S., and Hickey, J.J., 1992, A preliminary approach to the use of borehole data, including television surveys, for characterizing secondary porosity of carbonate rocks in the Floridan aquifer system: U.S. Geological Survey WaterResources Investigations Report 91-4168, 70 p.

Scott, T.M., 1988, The lithostratigraphy of the Hawthorn group (Miocene of Florida): Tallahassee, Florida Geological Survey Bulletin 59, 148 p.

SDI Environmental Services, Inc., 1993, Review of chloride concentration data from production wells located in the eastern Tampa Bay Water use caution area: Report prepared for West Coast Regional Water Supply Authority, SDI-Project No. WCF-613, 34 p.

Sinclair, W.C., Stewart, J.W., Knutilla, R.L., Gilboy, A.E., and Miller, R.L., 1985, Types, features, and occurrence of sinkholes in the karst of west-central Florida, U.S. Geological Survey Water-Resources Investigations Report 85-4126, $81 \mathrm{p}$.

Southwest Florida Water Management District, 1990, Groundwater quality sampling results from wells in the Southwest Florida Water Management District: Northern Region (Section 1), Ambient Ground-Water Quality Monitoring Program, March 1990.

Southwest Florida Water Management District, 1995, Coastal ground-water quality monitoring program report, Volume 3: $244 \mathrm{p}$.

Southwest Florida Water Management District, 1996a, Northern Tampa Bay Water Resources Assessment Project, Volume One, Surface-Water/Ground-Water Interrelationships.

Southwest Florida Water Management District, 1996b, Northern Tampa Bay Water Resources Assessment Project, Volume Two, Saline water instrusion and water quality.

Southwest Florida Water Management District, 2000a, Aquifer characteristics within the Southwest Florida Water Management District: Report 99-1, 122 p.

Southwest Florida Water Management District, 2000b, Coastal ground-water quality monitoring program report, Volume 4: $346 \mathrm{p}$.
Spechler, R.M., 1983, Chemical character of water in the upper part of the Floridan aquifer, near Tarpon Springs, Florida: Master's thesis, University of South Florida, 95 p.

Spechler, R.M., 1994, Saltwater intrusion and quality of water in the Floridan aquifer system, northeastern Florida: U.S. Geological Survey Water-Resources Investigations Report 92-4174, $76 \mathrm{p}$

Spratt, J.G., 1996, Application of surface geophysical methods to delineate fracture zones associated with photolinear features in west-central Florida: Keystone, Colo., Proceedings with papers, SAGEEP April 28-May 1, 1996.

Sprinkle, C.M., 1989, Geochemistry of the Floridan aquifer system in Florida, and in parts of Georgia, South Carolina, and Alabama: U.S. Geological Survey Professional Paper 1403-I, 105 p.

Stephenson, W.J., Odum, J.K., Shedlock, K.M., Pratt, T.L., and Williams, R.A., 1992, Mini-SOSIE high-resolution seismicreflection method aids hazard studies: Eos, American Geophysical Union Transactions, v. 73, no. 44, p. 473-476.

Stewart, J.W., 1968, Hydrologic effects of pumping from the Floridan aquifer in northwest Hillsborough, northeast Pinellas, and southwest Pasco Counties, Florida: U.S. Geological Survey Open-File Report, 241 p.

Stewart, J.W., Mills, L.R., Knochenmus, D.D., and Faulkner, G.L., 1971, Potentiometric surface and areas of artesian flow May 1969, and change of potentiometric surface 1964 to 1969, Floridan aquifer, Southwest Florida Water Management District, Florida: U.S. Geological Survey Hydrologic Investigations Atlas HA-440.

Trommer, J.T., 1992, Effects of effluent spray irrigation and sludge disposal on ground water in a karst region, northwest Pinellas County, Florida: U.S. Geological Survey WaterResources Investigations Report 91-4181, 32 p.

Trommer, J.T., 1993, Description and monitoring of the saltwater-freshwater transition zone in aquifers along the west-central coast of Florida: U.S. Geological Survey WaterResources Investigations Report 93-4120, 56 p.

U.S. Geological Survey, 1985, Summary of data from the hydrologic monitoring program in Eldridge-Wilde and East Lake Road well-field area, Pinellas and Hillsborough Counties, Florida, 1979-1983: U.S. Geological Survey Data Release, 27 p.

Vernon, R.O., 1951, Geology of Citrus and Levy Counties, Florida: Tallahassee Florida Geological Survey Bulletin 33, $256 \mathrm{p}$.

Water and Air Research, Inc., 2000, Comprehensive annual ecological monitoring and environmental assessment report for the Cosme-Odessa, EW, northwest Hillborough, Section 21, and south Pasco well field regions, water year 2000: Report prepared for Tampa Bay Water, $70 \mathrm{p}$. 
Water and Air Research, Inc., HSW Engineering, Inc, and Orniston, B.G., 2001, Comprehensive annual ecological monitoring and environmental assessment report for the Cosme-Odessa, EW, northwest Hillsborough, Section 21, and south Pasco wellfield regions, Water Year 2000: Final report prepared for Tampa Bay Water, June 2001, 01-5380-02, variably paginated.

Wilde, F.D., and Radtke, D.B., 1998, National field manual for the collection of water-quality data: U.S. Geological Survey, Techniques of Water-Resources Investigations, Book 9, Handbooks for Water-Resources Investigations, multiple pagination.

Williams, S.R., 1985, Relationship of ground-water chemistry to photolineaments in a karst aquifer: Master's thesis, University of South Florida, 138 p.

Wolansky, R.M., and Corral, M.A., Jr., 1985, Aquifer tests in west-central Florida, 1952-76: U.S. Geological Survey Water-Resources Investigations Report 84-4044, 127 p.

Wolansky, R.M., Mills, L.R., and Woodman, W.M., 1978a, Water table in the surficial aquifer and potentiometric surface of the Floridan aquifer in selected well fields, west-central Florida, May 1978: U.S. Geological Survey Open-File Report 78-939, 8 p., 4 sheets.

Wolansky, R.M., Mills, L.R., and Woodham, W.M., 1978b, Water table in the surficial aquifer and potentiometric of the Floridan aquifer in selected well fields, west-central Florida, September 1978: U.S. Geological Survey Open-File Report 78-1045, 8 p., 4 sheets.
Wolansky, R.M., Yobbi, D.K., Mills, L.R., and Woodham, W.M., 1979, Water table in the surficial aquifer and potentiometric of the Floridan aquifer in selected well fields, westcentral Florida, May 1979: U.S. Geological Survey OpenFile Report 79-1350, 2 sheets.

Yobbi, D.K., and Barr, G.L., 1982, Ground-water levels in selected well fields and in west-central Florida, September 1981: U.S. Geological Survey Open-File Report 82-261, 2 sheets.

Yobbi, D.K., Corral, M., and Torres, A.E., 1996, Trends in chloride, sulfate, and dissolved solids concentrations in water from selected public-supply and monitor wells in Tampa Bay area, Florida: U.S. Geological Survey Open-File Report 96-480, 42 p.

Yobbi, D.K., Mills, L.R., and Woodham, W.M., 1980a, Ground-water levels in selected well fields and west-central Florida, September 1979: U.S. Geological Survey Open-File Report 80-210, 2 sheets.

Yobbi, D.K., Mills, L.R., and Woodham, W.M., 1980b, Ground-water levels in selected well fields and west- central Florida, May 1980: U.S. Geological Survey Open-File Report 80-1001, 2 sheets.

Yobbi, D.K., Mills, L.R., and Woodham, W.M., 1980c, Ground-water levels in selected well fields and in westcentral Florida, September 1980: U.S. Geological Survey Open-File Report 81-77, 2 sheets.

Yobbi, D.K., and Woodham, W.M., 1981, Ground-water levels in selected well fields and west-central Florida, May 1981: U.S. Geological Survey Open-File Report 81-1106, 2 sheets. 
70 Effects of Aquifer Heterogeneity on Ground-Water Flow and Chloride Concentrations, West-Central Florida 
Appendixes A and B 


\section{Effects of Aquifer Heterogeneity on Ground-Water Flow and Chloride Concentrations, West-Central Florida}

Appendix A. Well-construction, specific-capacity, and pump-capacity data for production wells at the Eldridge-Wilde well field.

[ft, feet; gal/min, gallons per minute; ft²/d, feet squared per day. Data from Black, Crow, and Eidsness Inc. (1970); Gee and Jenson Inc. (1981a,b; 1983); and Nettles and Vandor Inc. (1985)]

\begin{tabular}{|c|c|c|c|c|c|c|c|c|c|}
\hline $\begin{array}{l}\text { Well } \\
\text { name }\end{array}$ & $\begin{array}{c}\text { Year } \\
\text { constructed/ } \\
\text { modified }^{\mathrm{a}}\end{array}$ & $\begin{array}{c}\text { Diameter } \\
\text { (inches) }\end{array}$ & $\begin{array}{l}\text { Well } \\
\text { depth } \\
\text { original/ } \\
\text { modified } \\
\quad(\mathrm{ft})\end{array}$ & $\begin{array}{l}\text { Casing } \\
\text { depth } \\
\text { (ft) }\end{array}$ & $\begin{array}{l}\text { Length open hole } \\
\text { original/ } \\
\text { modified } \\
\text { (ft) }\end{array}$ & $\begin{array}{c}\text { Specific } \\
\text { capacity } \\
\text { original/final } \\
(\mathrm{gal} / \mathrm{min}) / \mathrm{ft}\end{array}$ & $\begin{array}{c}\text { Specific capacity } \\
\text { per foot } \\
\text { saturated } \\
\text { thickness } \\
\text { original/final } \\
{[(\mathrm{gal} / \mathrm{min}) / \mathrm{ft}] / \mathrm{ft}}\end{array}$ & $\begin{array}{l}\text { Transmissivity } \\
\text { calculated from } \\
\text { final specific } \\
\text { capacityc } \\
\left(\mathrm{ft}^{2} / \mathrm{d}\right)\end{array}$ & $\begin{array}{c}\text { Pump } \\
\text { capacity }\end{array}$ \\
\hline 1 & 1954 & 12 & 300 & 89 & 211 & 49 & 0.23 & 13,100 & 700 \\
\hline $1 \mathrm{~S}$ & 1954 & 12 & 299 & 65 & 234 & $67 / 53$ & $0.29 / 0.23$ & 14,200 & 700 \\
\hline 2 & 1954 & 12 & 297 & 80 & 217 & 94 & 0.43 & 25,100 & 700 \\
\hline 4 & 1954 & 12 & 300 & 112 & 188 & 188 & 1.00 & 50,300 & 700 \\
\hline 6 & 1954 & 12 & 300 & 77 & 223 & $130 / 169$ & $0.58 / 0.76$ & 45,200 & 700 \\
\hline $4 \mathrm{~S}$ & 1955 & 12 & 285 & 65 & 220 & 46 & 0.21 & 12,300 & 700 \\
\hline $5 \mathrm{~S}$ & 1955 & 12 & 175 & 124 & 51 & $58 / 57$ & $1.14 / 1.12$ & 15,200 & 700 \\
\hline $6 \mathrm{~S}$ & 1955 & 12 & 140 & 76 & 64 & $65 / 41$ & $1.02 / 0.64$ & 11,000 & 700 \\
\hline 7 & 1955 & 12 & 285 & 92 & 193 & $86 / 101$ & $0.45 / 0.52$ & 27,000 & 700 \\
\hline $7 \mathrm{~S}$ & 1955 & 12 & 290 & 63 & 227 & $130 / 60$ & $0.57 / 0.26$ & 16,000 & 700 \\
\hline $8 \mathrm{~S}$ & 1955 & 12 & 245 & 95 & 150 & 193 & 1.29 & 51,600 & 700 \\
\hline $3 \mathrm{~S}$ & 1956 & 12 & 309 & 88 & 221 & 49 & 0.22 & 13,100 & 700 \\
\hline 5 & 1956 & 12 & 210 & 76 & 134 & 200 & 1.49 & 53,500 & 700 \\
\hline 8 & 1957 & 12 & 300 & 69 & 231 & $320 / 191$ & $1.39 / 0.83$ & 51,100 & 1,200 \\
\hline 9 & 1957 & 12 & 302 & 75 & 227 & 221 & 0.97 & 59,100 & 1,200 \\
\hline $4 \mathrm{~N}$ & 1958 & 12 & 300 & 103 & 197 & 200 & 1.02 & 53,500 & 700 \\
\hline $5 \mathrm{~A}$ & 1958 & 12 & 295 & 103 & 192 & 175 & 0.91 & 46,800 & 700 \\
\hline $6 \mathrm{~N}$ & 1958 & 12 & 346 & 96 & 250 & 93 & 0.37 & 24,900 & 700 \\
\hline $4 \mathrm{~A}$ & 1960 & 12 & 210 & 74 & 136 & 223 & 1.64 & 59,600 & 1,400 \\
\hline $5 \mathrm{~B}$ & 1960 & 16 & 300 & 75 & 225 & 111 & 0.49 & 29,700 & 1,400 \\
\hline $11 \mathrm{~A}$ & 1961 & 16 & 300 & 86 & 214 & 311 & 1.45 & 83,200 & 1,400 \\
\hline 12 & 1961 & 16 & 300 & 66 & 234 & 95 & 0.41 & 25,400 & 1,400 \\
\hline 101 & 1961 & 16 & 311 & 149 & 162 & 600 & 3.70 & 160,400 & 1,400 \\
\hline 106 & 1961 & 16 & 345 & 97 & 248 & 103 & 0.42 & 27,500 & 1,400 \\
\hline 107 & 1961 & 16 & 308 & 80 & 228 & 175 & 0.77 & 46,800 & 1,400 \\
\hline 104 & 1964 & 16 & 403 & 72 & 331 & 89 & 0.27 & 23,800 & 1,400 \\
\hline 112 & 1964 & 16 & 314 & 62 & 252 & 259 & 1.03 & 69,200 & 2,100 \\
\hline 115 & 1964 & 16 & 321 & 84 & 237 & 103 & $0.44 / 0.43$ & 27,500 & 1,400 \\
\hline 116 & 1964 & 16 & 400 & 60 & 340 & $146 / 122$ & $0.43 / 0.36$ & 32,600 & 1,400 \\
\hline 117 & 1964 & 16 & 302 & 80 & 222 & 65 & 0.29 & 17,400 & 1,400 \\
\hline 119 & 1964 & 16 & 407 & 124 & 283 & 160 & 0.57 & 42,800 & 1,400 \\
\hline 142 & 1966 & 16 & 400 & 66 & 334 & 84 & 0.25 & 22,500 & 1,400 \\
\hline $10 \mathrm{~A}$ & 1969 & 16 & 550 & 99 & 451 & 93 & 0.21 & 24,900 & 1,400 \\
\hline $2 \mathrm{~A}$ & 1970 & 12 & $450 / 340$ & 113 & $337 / 227$ & 130 & 0.39 & 34,800 & 700 \\
\hline $3 B$ & 1970 & 12 & $410 / 390$ & 78 & $332 / 312$ & 40 & 0.12 & 10,700 & 700 \\
\hline $5 \mathrm{~N}$ & $1958 / 1980$ & 12 & $340 / 863$ & 107 & $233 / 756$ & $39 / 122$ & $0.17 / 0.16$ & 32,600 & 700 \\
\hline 13 & $1961 / 1981$ & 16 & $320 / 780$ & 72 & $248 / 708$ & $50 / 362$ & $0.20 / 0.51$ & 96,800 & 1,400 \\
\hline 105 & $1961 / 1983$ & 16 & $250 / 658$ & 82 & $168 / 576$ & $59 / 345$ & $0.35 / 0.60$ & 92,200 & 1,400 \\
\hline 103 & $1961 / 1985$ & 16 & $310 / 767$ & 85 & $225 / 682$ & $100 / 319$ & $0.44 / 0.47$ & 85,300 & 1,400 \\
\hline 109 & $1961 / 1985$ & 16 & $384 / 770$ & 85 & $299 / 685$ & $27 / 364$ & $0.09 / 0.53$ & 97,300 & 700 \\
\hline 110 & $1961 / 1985$ & 16 & $333 / 776$ & 64 & $269 / 712$ & $51 / 214$ & $0.19 / 0.30$ & 57,200 & 700 \\
\hline 102 & $1961 / 1985$ & 16 & $316 / 774$ & 79 & $237 / 695$ & $171 / 408$ & $0.72 / 0.59$ & 109,100 & 1,400 \\
\hline 113 & 1964 / 1985 & $12 / 16$ & $503 / 647$ & 100 & $403 / 547$ & $65 / 308$ & $0.16 / 0.56$ & 82,300 & 1,400 \\
\hline 114 & 1964 / 1985 & 16 & $407 / 776$ & 58 & $349 / 718$ & $53 / 339$ & $0.15 / 0.47$ & 90,600 & 1,400 \\
\hline 118 & 1964 / 1985 & 16 & $407 / 775$ & 78 & $329 / 697$ & $31 / 86$ & $0.09 / 0.12$ & 23,000 & 1,400 \\
\hline
\end{tabular}


Appendix A. Well-construction, specific-capacity, and pump-capacity data for production wells at the Eldridge-Wilde well field. (Continued) [ft, feet; gal/min, gallons per minute; ft²/d, feet squared per day. Data from Black, Crow, and Eidsness Inc. (1970); Gee and Jenson Inc. (1981a,b; 1983); and Nettles and Vandor Inc. (1985)]

\begin{tabular}{|c|c|c|c|c|c|c|c|c|c|}
\hline $\begin{array}{l}\text { Well } \\
\text { name }\end{array}$ & $\begin{array}{c}\text { Year } \\
\text { constructed/ } \\
\text { modified }^{\mathrm{a}}\end{array}$ & $\begin{array}{c}\text { Diameter } \\
\text { (inches) }\end{array}$ & $\begin{array}{c}\text { Well } \\
\text { depth } \\
\text { original/ } \\
\text { modified } \\
\text { (ft) }\end{array}$ & $\begin{array}{l}\text { Casing } \\
\text { depth } \\
\text { (ft) }\end{array}$ & $\begin{array}{l}\text { Length open hole } \\
\text { original/ } \\
\text { modified } \\
\text { (ft) }\end{array}$ & $\begin{array}{c}\text { Specific } \\
\text { capacity } \\
\text { original/final } \\
\text { (gal/min)/ft }\end{array}$ & $\begin{array}{c}\text { Specific capacity } \\
\text { per foot } \\
\text { saturated } \\
\text { thickness } \\
\text { original/final } \\
{[(\mathrm{gal} / \mathrm{min}) / \mathrm{ft}] / \mathrm{ft}}\end{array}$ & $\begin{array}{l}\text { Transmissivity } \\
\text { calculated from } \\
\text { final specific } \\
\text { capacityc } \\
\left(\mathrm{ft}^{2} / \mathrm{d}\right)\end{array}$ & $\begin{array}{c}\text { Pump } \\
\text { capacity }\end{array}$ \\
\hline 111 & 1964 / 1983 & 16 & $399 / 780$ & 71 & $328 / 709$ & $78 / 400$ & $0.24 / 0.56$ & 106,900 & 1,400 \\
\hline 139 & 1966 / 1981 & 16 & $560 / 780$ & 63 & $497 / 717$ & $27 / 264$ & $0.05 / 0.37$ & 70,600 & 700 \\
\hline 136 & $1966 / 1982$ & 16 & $430 / 780$ & 60 & $370 / 720$ & $150 / 328$ & $0.41 / 0.46$ & 87,700 & 1,400 \\
\hline 137 & $1966 / 1982$ & 16 & $330 / 780$ & 84 & $246 / 696$ & $97 / 343$ & $0.39 / 0.49$ & 91,700 & 1,400 \\
\hline 140 & $1966 / 1982$ & 16 & $440 / 780$ & 66 & $374 / 714$ & $59 / 121$ & $0.16 / 0.17$ & 32,400 & 700 \\
\hline 138 & $1966 / 1985$ & 16 & $400 / 778$ & 58 & $342 / 720$ & $34 / 363$ & $0.10 / 0.50$ & 97,100 & 700 \\
\hline 141 & $1966 / 1985$ & 16 & $510 / 780$ & 63 & $447 / 717$ & $13 / 155$ & $0.03 / 0.22$ & 41,400 & 700 \\
\hline 134 & $1966 / 1986$ & 16 & $275 / 778$ & 84 & $191 / 694$ & $209 / 507$ & $1.09 / 0.73$ & 135,600 & 1,400 \\
\hline 135 & $1966 / 1986$ & 16 & $287 / 778$ & 63 & $224 / 715$ & $140 / 373$ & $0.63 / 0.52$ & 99,700 & 1,400 \\
\hline 131 & $1966 / 1985$ & 16 & $460 / 778$ & 83 & $377 / 695$ & $90 / 490$ & $0.24 / 0.17$ & 131,000 & 700 \\
\hline 120 & $1970 / 1986 \mathrm{~A}$ & 16 & 809 & 78 & 731 & $77 / 135$ & $0.11 / 0.18$ & 36,100 & 1,400 \\
\hline 121 & 1970 / 1986A & 16 & 770 & 116 & 654 & $110 / 207$ & $0.17 / 0.32$ & 55,300 & 1,400 \\
\hline 122 & $1970 / 1986$ & 16 & $291 / 780$ & 123 & $168 / 657$ & $231 / 563$ & $1.38 / 0.86$ & 150,500 & 1,400 \\
\hline
\end{tabular}

andicates well was modified by acidizing.

${ }^{b}$ Original specific capacity determined after initial construction. Final specific capacity determined at later date or after modification or deepening. 'Driscoll (1986).

dBased on available data in 2003. 


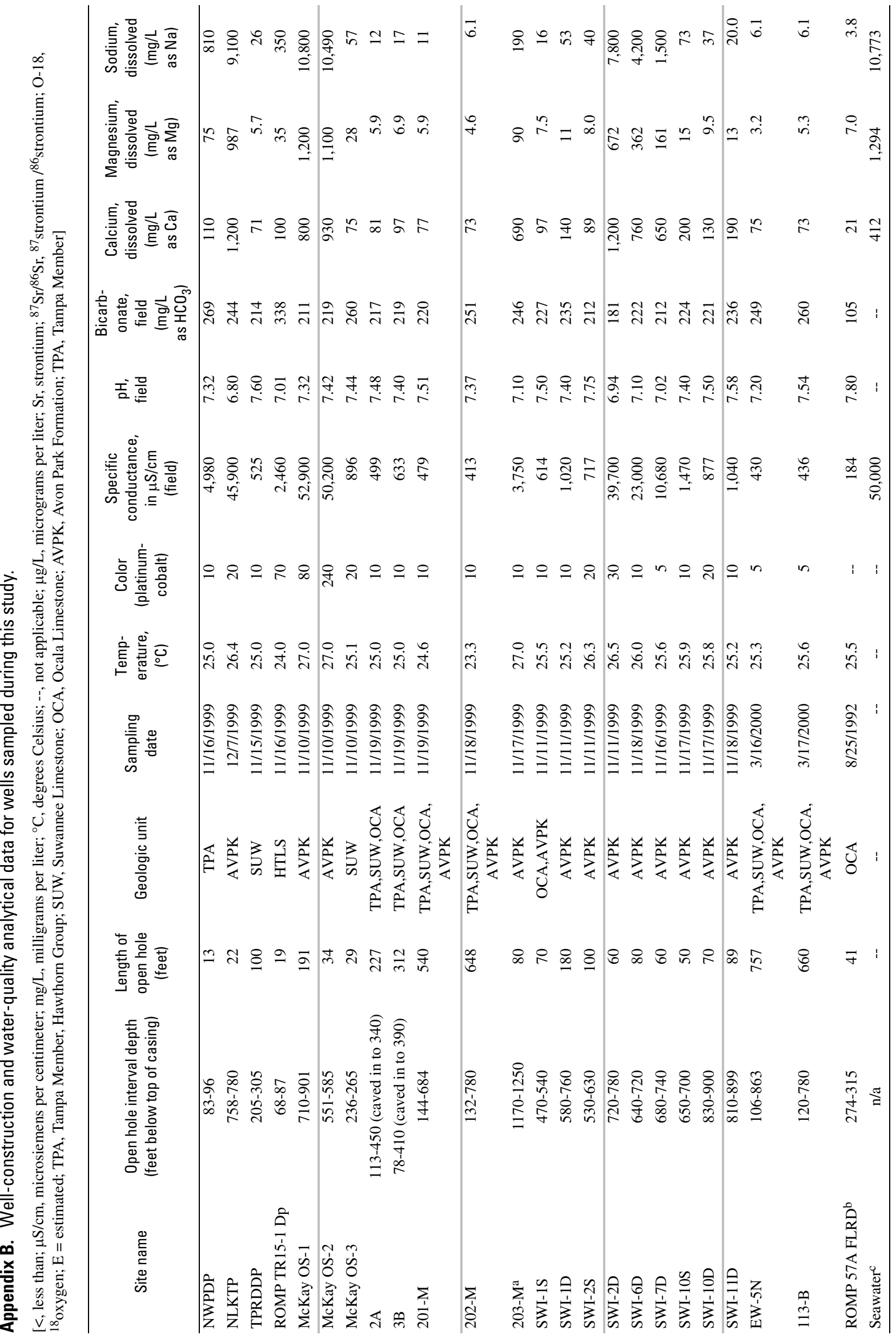




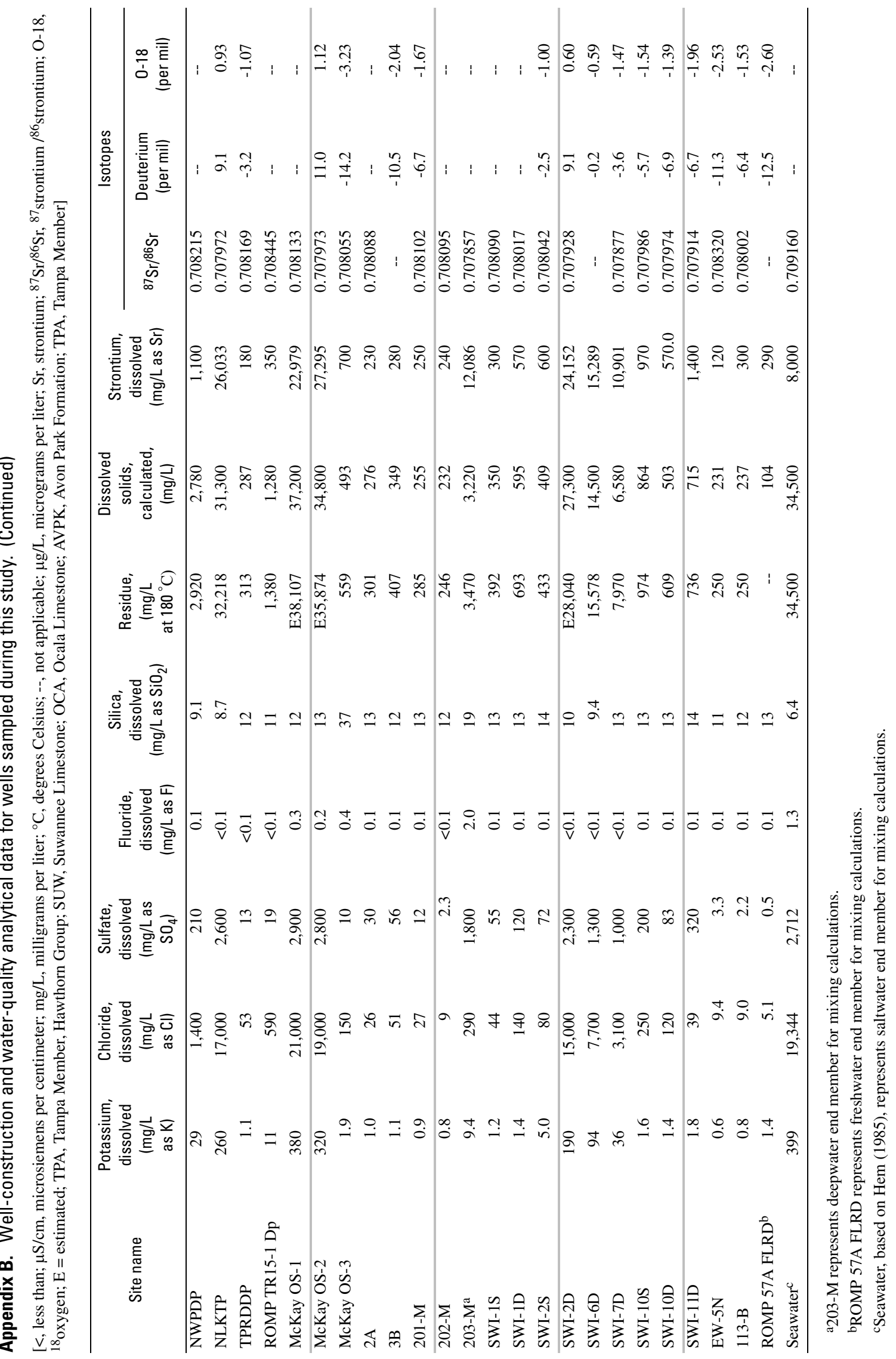

